\title{
HYDROGEOLOGIC INVESTIGATION OF THE MALVERN TCE SUPERFUND SITE, Chester County, Pennsylvania
}

U.S. GEOLOGICAL SURVEY

Water-Resources Investigations Report 96-4286

Prepared in cooperation with the U.S. Environmental Protection Agency

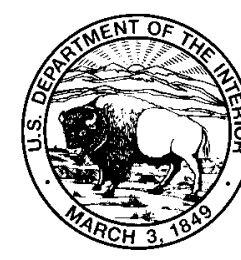




\section{HYDROGEOLOGIC INVESTIGATION OF THE MALVERN TCE SUPERFUND SITE, CHESTER COUNTY, PENNSYLVANIA}

By Ronald A. Sloto

U.S. GEOLOGICAL SURVEY

Water-Resources Investigations Report 96-4286

Prepared in cooperation with the

U.S. Environmental Protection Agency

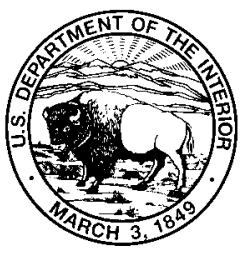

Lemoyne, Pennsylvania 1997 


\title{
U.S. DEPARTMENT OF THE INTERIOR \\ BRUCE BABBITT, Secretary
}

\author{
U.S. GEOLOGICAL SURVEY \\ Gordon P. Eaton, Director
}

For additional information

write to:

District Chief

U.S. Geological Survey

840 Market Street

Lemoyne, Pennsylvania 17043-1586
Copies of this report may be purchased from:

U.S. Geological Survey

Branch of Information Services

Box 25286

Denver, Colorado 80225-0286 


\section{CONTENTS}

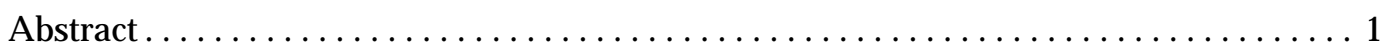

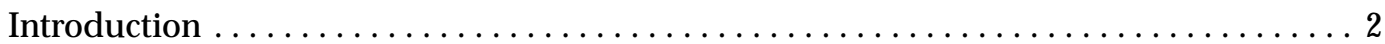

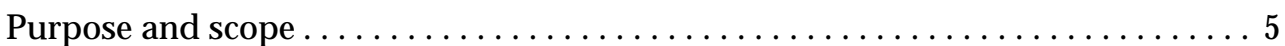

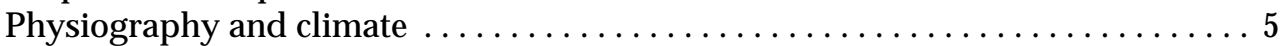

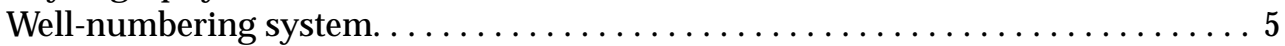

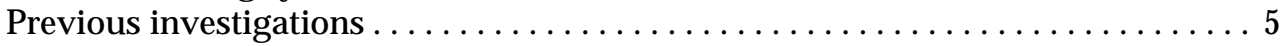

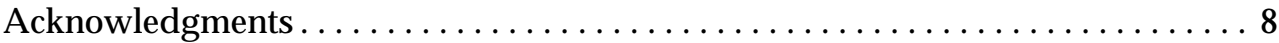

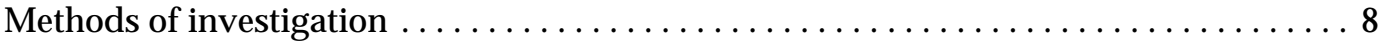

Borehole geophysics........................ 8

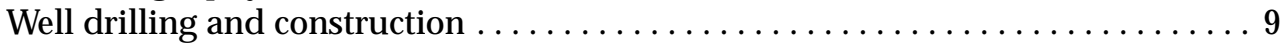

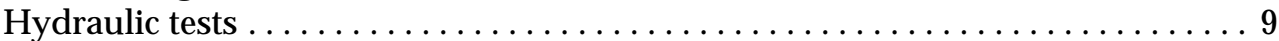

Capture-zone analysis . . . . . . . . . . . . . . . . . . . . . . 11

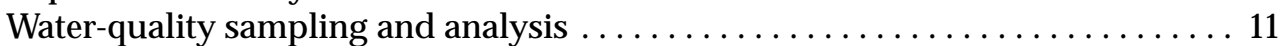

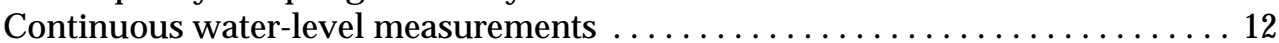

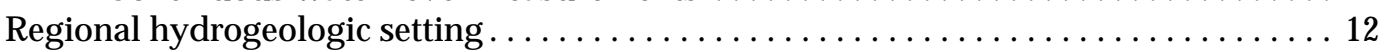

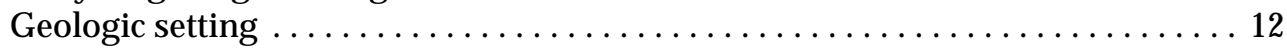

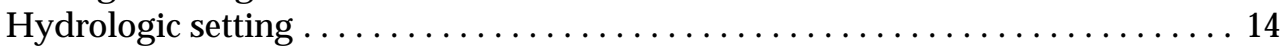

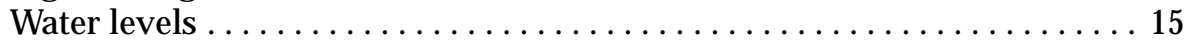

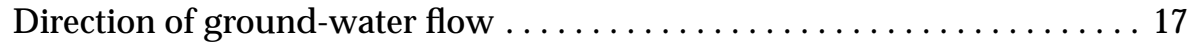

Hydrogeology and contaminant distribution ........................ 19

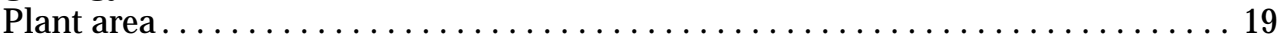

Results of borehole geophysical logging. ................. 20

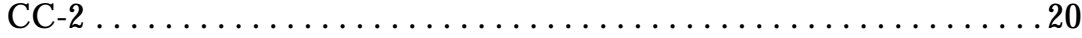

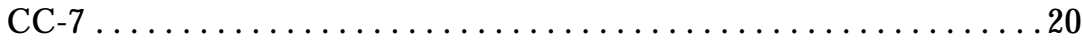

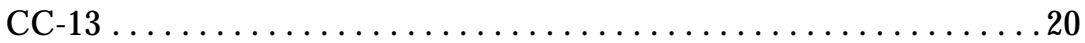

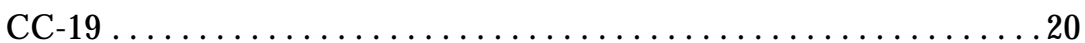

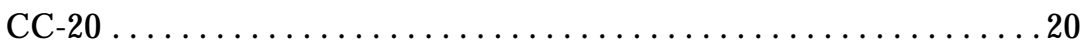

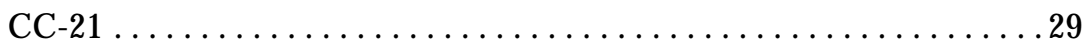

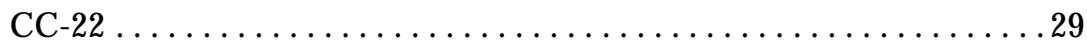

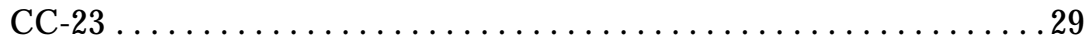

Results of aquifer tests ........................... 34

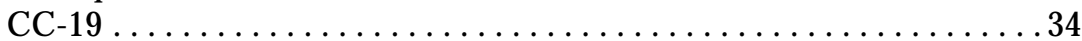

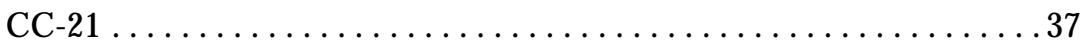

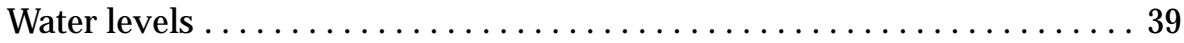

Distribution of volatile organic compounds................ 39

Hydrogeologic framework . . . . . . . . . . . . . . . . . . . . 42

Disposal area..................................... 42

Results of borehole geophysical logging. ................. 42

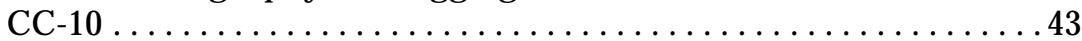

CC-15, CC-16, CC-17, and CC-18................... 43

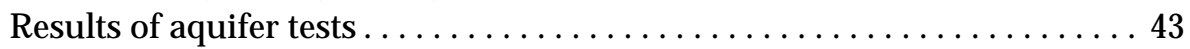

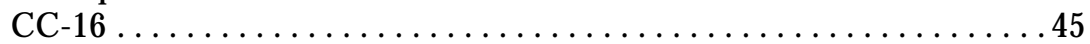

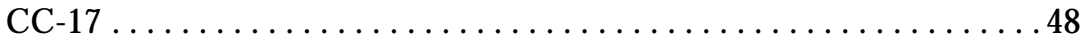

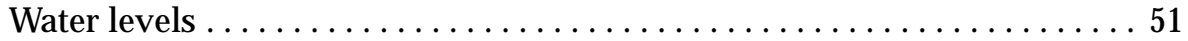

Distribution of volatile organic compounds................ 51

Hydrogeologic framework ............................. 55 


\section{CONTENTS}

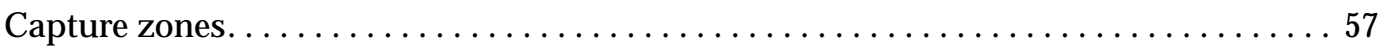

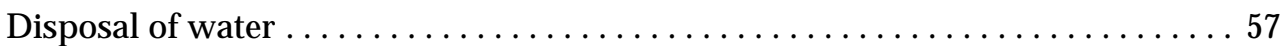

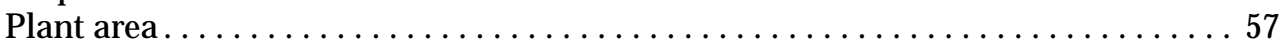

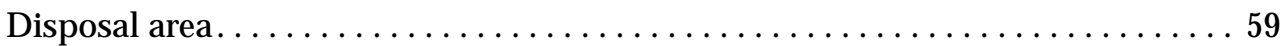

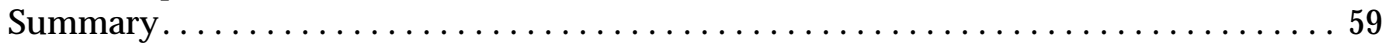

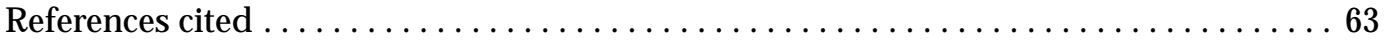

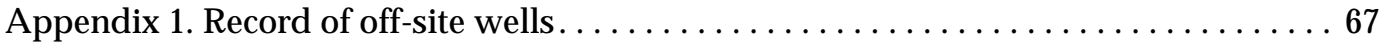

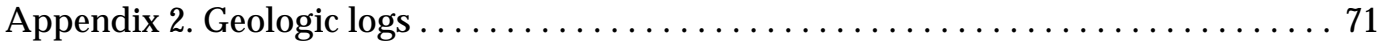

Appendix 3. Well-construction diagrams.......................... 79

Appendix 4. Graphs of drawdown and recovery measured during aquifer tests. . . . . 90

Appendix 5. Monthly water-level measurements. ......................... 113

Appendix 6. Results of chemical analyses for volatile organic compounds. . . . . . . 117

\section{PLATE [IN POCKET]}

1. Altitude and configuration of the potentiometric surface, December 6, 1994,

Malvern TCE Superfund Site and vicinity, Chester County, Pennsylvania

\section{FIGURES}

1. Map showing the location of the Malvern TCE Site and selected wells,

Chester County, Pennsylvania .............................

2. Map showing the location of wells at the Malvern TCE Site, Chester County,

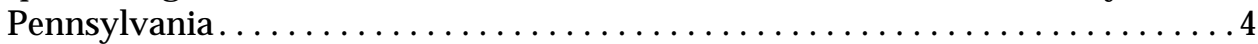

3. Map showing the location of domestic wells near the Malvern TCE Site, Chester County, Pennsylvania ............................

4. Geologic map of the Malvern TCE Site and vicinity, Chester County,

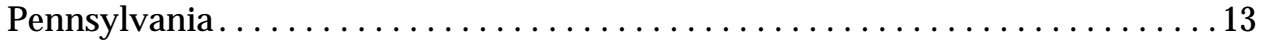

5. Hydrograph from well CC-2, October 1995, Malvern TCE Site, and precipitation at Phoenixville, Chester County, Pennsylvania . . . . . . . . . . 16

6. Hydrograph from well CH-2313, April 21, 1978, to May 20, 1996, East Whiteland Township, Chester County, Pennsylvania ............... 16

7. Hydrograph from well CH-2313, February 22, 1995, to March 28, 1996, East Whiteland Township, Chester County, Pennsylvania .............. 17

8. Hydrograph from well CH-4394, February 23, 1995, to March 28, 1996, East Whiteland Township, Chester County, Pennsylvania ............... 17

9. Map showing generalized ground-water-flow directions in the vicinity of the Malvern TCE Site, Chester County, Pennsylvania ................... 18

10. Map showing location of wells at the plant area, Malvern TCE Site, Chester County, Pennsylvania . . . . . . . . . . . . . . . . . . . . . . 19

11. Borehole geophysical logs for well CC-2, Malvern TCE Site, Chester County,

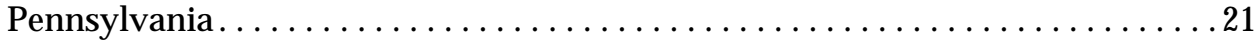




\section{FIGURES}

12. Images from borehole television survey showing fractures in well CC-2, Malvern TCE Site, Chester County, Pennsylvania ................. 22

13. Caliper log for well CC-7, Malvern TCE Site, Chester County, Pennsylvania . . . . 24

14. Image from borehole television survey showing fracture at 84.7 feet below land surface in well CC-7, Malvern TCE Site, Chester County, Pennsylvania . . . 24

15. Borehole geophysical logs for well CC-13, Malvern TCE Site, Chester County,

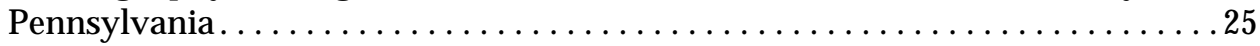

16. Borehole geophysical logs for well CC-19, Malvern TCE Site, Chester County,

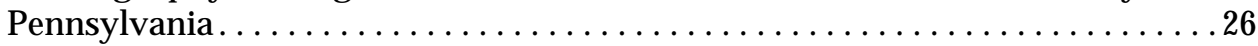

17. Images from borehole television survey showing fractures in well CC-19, Malvern TCE Site, Chester County, Pennsylvania . . . . . . . . . . . . . 2 27

18. Borehole geophysical logs for well CC-20, Malvern TCE Site, Chester County,

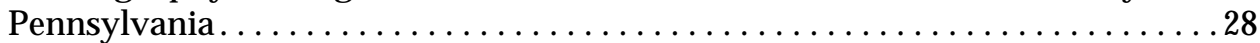

19. Image from borehole television survey showing fracture at 250 feet below land surface in well CC-20, Malvern TCE Site, Chester County, Pennsylvania . . 29

20. Natural-gamma log for well CC-21, Malvern TCE Site, Chester County,

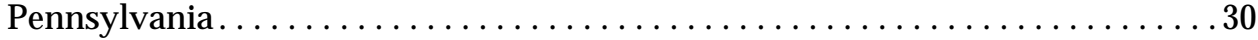

21. Borehole geophysical logs for well CC-22, Malvern TCE Site, Chester County,

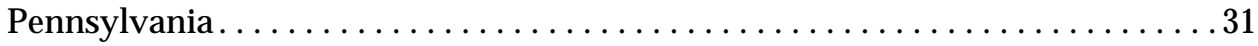

22. Images from borehole television survey showing fracture in well CC-22, Malvern TCE Site, Chester County, Pennsylvania .................... 32

23. Borehole geophysical logs for well CC-23, Malvern TCE Site, Chester County,

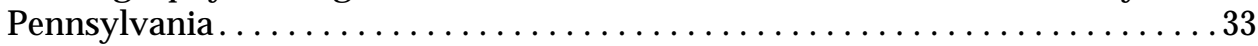

24. Diagram showing packer, pump, and transducers in well CC-19, Malvern TCE Site, Chester County, Pennsylvania ........................ 34

25. Hydrograph from well CC-2, May 8-30, 1996, Malvern TCE Site, Chester County, Pennsylvania ................................... 35

26. Graph showing relation between drawdown in well CC-19 and time for aquifer test of well CC-19, May 21-22, 1996, Malvern TCE Site, Chester County, Pennsylvania . . . . . . . . . . . . . . . . . . . . . . 36

27. Graph showing relation between drawdown in observation wells and distance for aquifer test of well CC-19, May 21-22, 1996, Malvern TCE Site, Chester County, Pennsylvania . . . . . . . . . . . . . . . . . . . . . . . 37

28. Diagram showing generalized cross-section of the plant area, Malvern TCE Site, Chester County, Pennsylvania .................... 38

29. Graph showing relation between drawdown in well CC-19 and time for recovery phase of aquifer test of well CC-19, May 22, 1996, Malvern TCE Site, Chester County, Pennsylvania 


\section{FIGURES}

30. Graph showing relation between drawdown in well CC-21 and time for aquifer test of well CC-21, May 23-24, 1996, Malvern TCE Site,

Chester County, Pennsylvania .............................. 39

31. Graph showing relation between drawdown in well CC-21 and time for recovery phase of aquifer test of well CC-21, May 24, 1996,

Malvern TCE Site, Chester County, Pennsylvania . .

32. Hydrographs from wells CC-2, CC-9, and CC-13, February 1995 to May 1996, Malvern TCE Site, Chester County, Pennsylvania .............. . 40

33. Hydrographs (depth to water) from wells measured monthly at the plant area, January 1995 to May 1996, Malvern TCE Site, Chester County, Pennsylvania.

34. Map showing concentrations of trichloroethylene, tetrachloroethylene, and 1,1,1-trichloroethane in water from wells at the plant area, May 1996, Malvern TCE Site, Chester County, Pennsylvania .................. 41

35. Map showing the location of wells at the disposal area, Malvern TCE Site, Chester County, Pennsylvania ............................. 43

36. Natural-gamma log for well CC-10, Malvern TCE Site, Chester County, Pennsylvania...................................... 44

37. Natural-gamma logs for wells CC-15, CC-16, CC-17, and CC-18, Malvern TCE Site, Chester County, Pennsylvania . . . . . . . . . . . . . . . . 44

38. Diagram showing generalized cross-section of the disposal area, Malvern TCE Site, Chester County, Pennsylvania . . . . . . . . . . . . . . . . 45

39. Graph showing relation between drawdown in well CC-16 and time for aquifer test of well CC-16, May 14-15, 1996, Malvern TCE Site, Chester County, Pennsylvania . .

40. Graph showing relation between drawdown in observation wells and time for aquifer test of well CC-16, May 14-15, 1996, Malvern TCE Site,

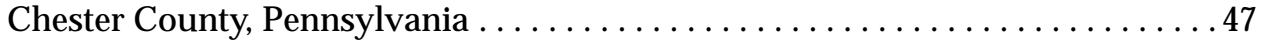

41. Graph showing relation between drawdown in well CC-16 and time for recovery phase of aquifer test of well CC-16, May 15, 1996, Malvern TCE Site, Chester County, Pennsylvania ................... 48

42. Graph showing relation between drawdown in well CC-17 and time for aquifer test of well CC-17, May 16-17, 1996, Malvern TCE Site, Chester County, Pennsylvania ...

43. Graph showing relation between drawdown in observation wells and time for aquifer test of well CC-17, May 16-17, 1996, Malvern TCE Site, Chester County, Pennsylvania

44. Graph showing relation between drawdown in well CC-17 and time for recovery phase of aquifer test of well CC-17, May 17, 1996, Malvern TCE Site, Chester County, Pennsylvania 


\section{FIGURES}

45. Hydrographs (depth to water) from wells measured monthly at the disposal area, January 1995 to May 1996, Malvern TCE Site, Chester County, Pennsylvania . . . . . . . . . . . . . . . . . . . . . . 51

46. Hydrographs (altitude above sea level) from wells measured monthly at the disposal area, January 1995 to May 1996, Malvern TCE Site, Chester County, Pennsylvania . . . . . . . . . . . . . . . . . . . . . . . . . . 51

47. Map showing concentrations of trichloroethylene in water from wells at the disposal area and Hillbrook Circle, 1995-96, Malvern TCE Site, Chester County, Pennsylvania ............................... 52

48. Map showing concentrations of tetrachloroethylene in water from wells at the disposal area and Hillbrook Circle, 1995-96, Malvern TCE Site, Chester County, Pennsylvania . . . . . . . . . . . . . . . . . . . . . . . 53

49. Map showing concentrations of 1,1,1-trichloroethane in water from wells at the disposal area and Hillbrook Circle, 1995-96, Malvern TCE Site, Chester County, Pennsylvania .............................. 54

50. Map showing location of wells in which volatile organic compounds were detected in water samples, disposal area and Hillbrook Circle, 1981-84, Malvern TCE Site, Chester County, Pennsylvania .................... 56

51. Map showing capture zone formed by pumping wells CC-19 and CC-21 at the plant area, Malvern TCE Site, Chester County, Pennsylvania ......... 58

52. Map showing capture zone formed by pumping well CC-19 at the plant area, Malvern TCE Site, Chester County, Pennsylvania .................. 58

53. Map showing capture zone formed by pumping wells CC-16 and CC-17 at the disposal area, Malvern TCE Site, Chester County, Pennsylvania

54. Map showing capture zone formed by pumping wells CC-16, CC-17, and CC-18 at the disposal area, Malvern TCE Site, 


\section{FIGURES IN APPENDIX 3}

1-10. Well-construction diagrams for wells at the Malvern TCE Site, Chester County, Pennsylvania:

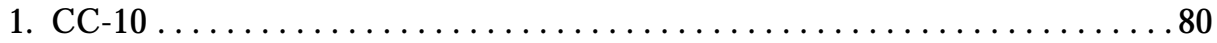

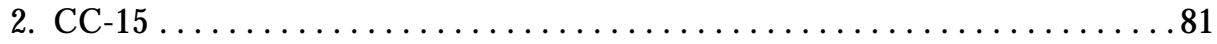

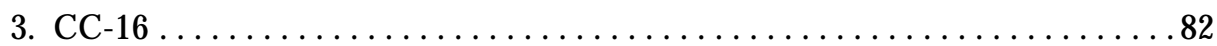

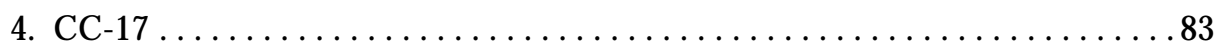

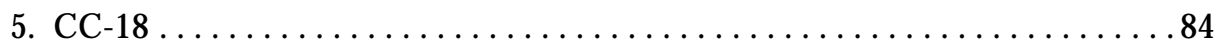

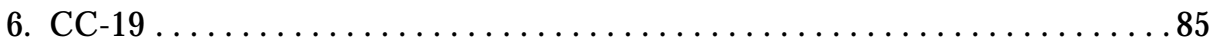

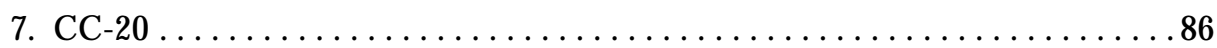

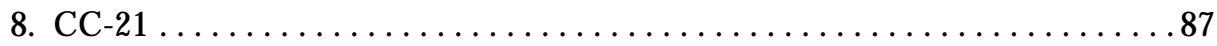

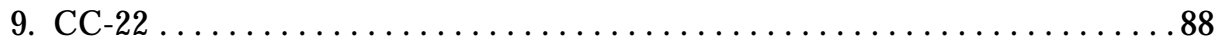

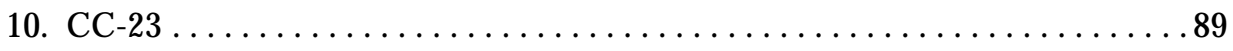

\section{FIGURES IN APPENDIX 4}

1-43. Graphs showing:

1. Relation between drawdown in well CC-3 and time for aquifer test of well CC-19, May 21-22, 1996, Malvern TCE Site, Chester County, Pennsylvania

2. Relation between drawdown in well CC-6 and time for aquifer test of well CC-19, May 21-22, 1996, Malvern TCE Site, Chester County, Pennsylvania

3. Relation between drawdown in well CC-7 and time for aquifer test of well CC-19, May 21-22, 1996, Malvern TCE Site, Chester County, Pennsylvania

4. Relation between drawdown in well CC-13 and time for aquifer test of well CC-19, May 21-22, 1996, Malvern TCE Site, Chester County, Pennsylvania

5. Relation between drawdown in well CC-20 and time for aquifer test of well CC-19, May 21-22, 1996, Malvern TCE Site, Chester County, Pennsylvania

6. Relation between drawdown in well CC-21 and time for aquifer test of well CC-19, May 21-22, 1996, Malvern TCE Site, Chester County, Pennsylvania

7. Relation between drawdown in well CC-22 and time for aquifer test of well CC-19, May 21-22, 1996, Malvern TCE Site, Chester County, Pennsylvania 


\section{FIGURES IN APPENDIX 4}

1-43. Graphs showing:

8. Relation between drawdown in well CC-3 and time for recovery phase of aquifer test of well CC-19, May 22, 1996, Malvern TCE Site, Chester County, Pennsylvania.

9. Relation between drawdown in well CC-6 and time for recovery phase of aquifer test of well CC-19, May 22, 1996, Malvern TCE Site, Chester County, Pennsylvania.

10. Relation between drawdown in well CC-7 and time for recovery phase of aquifer test of well CC-19, May 22, 1996, Malvern TCE Site, Chester County, Pennsylvania.

11. Relation between drawdown in well CC-13 and time for recovery phase of aquifer test of well CC-19, May 22, 1996, Malvern TCE Site, Chester County, Pennsylvania.

12. Relation between drawdown in well CC-20 and time for recovery phase of aquifer test of well CC-19, May 22, 1996, Malvern TCE Site, Chester County, Pennsylvania.

13. Relation between drawdown in well CC-21 and time for recovery phase of aquifer test of well CC-19, May 22, 1996, Malvern TCE Site, Chester County, Pennsylvania.

14. Relation between drawdown in well CC-22 and time for recovery phase of aquifer test of well CC-19, May 22, 1996, Malvern TCE Site, Chester County, Pennsylvania.

15. Relation between drawdown in well CC-3 and time for aquifer test of well CC-21, May 23-24, 1996, Malvern TCE Site, Chester County, Pennsylvania

16. Relation between drawdown in well CC- 6 and time for aquifer test of well CC-21, May 23-24, 1996, Malvern TCE Site, Chester County, Pennsylvania

17. Relation between drawdown in well CC-7 and time for aquifer test of well CC-21, May 23-24, 1996, Malvern TCE Site, Chester County, Pennsylvania .................................99

18. Relation between drawdown in well CC-13 and time for aquifer test of well CC-21, May 23-24, 1996, Malvern TCE Site, Chester County, Pennsylvania

19. Relation between drawdown in well CC-19 and time for aquifer test of well CC-21, May 23-24, 1996, Malvern TCE Site, Chester County, Pennsylvania ................................... 100 


\section{FIGURES IN APPENDIX 4}

1-43. Graphs showing:

20. Relation between drawdown in well CC-20 and time for aquifer test of well CC-21, May 23-24, 1996, Malvern TCE Site, Chester County, Pennsylvania

21. Relation between drawdown in well CC-22 and time for aquifer test of well CC-21, May 23-24, 1996, Malvern TCE Site, Chester County,

Pennsylvania

22. Relation between drawdown in well CC-3 and time for recovery phase of aquifer test of well CC-21, May 24, 1996, Malvern TCE Site, Chester County, Pennsylvania.

23. Relation between drawdown in well CC- 6 and time for recovery phase of aquifer test of well CC-21, May 24, 1996, Malvern TCE Site, Chester County, Pennsylvania.

24. Relation between drawdown in well CC-7 and time for recovery phase of aquifer test of well CC-21, May 24, 1996, Malvern TCE Site, Chester County, Pennsylvania.

25. Relation between drawdown in well CC-13 and time for recovery phase of aquifer test of well CC-21, May 24, 1996, Malvern TCE Site, Chester County, Pennsylvania.

26. Relation between drawdown in well CC-19 and time for recovery phase of aquifer test of well CC-21, May 24, 1996, Malvern TCE Site, Chester County, Pennsylvania.

27. Relation between drawdown in well CC-20 and time for recovery phase of aquifer test of well CC-21, May 24, 1996, Malvern TCE Site, Chester County, Pennsylvania.

28. Relation between drawdown in well CC-22 and time for recovery phase of aquifer test of well CC-21, May 24, 1996, Malvern TCE Site, Chester County, Pennsylvania.

29. Relation between drawdown in well CC- 5 and time for aquifer test of well CC-16, May 14-15, 1996, Malvern TCE Site, Chester County, Pennsylvania ..................................... 105

30. Relation between drawdown in well CC-9 and time for aquifer test of well CC-16, May 14-15, 1996, Malvern TCE Site, Chester County, Pennsylvania

31. Relation between drawdown in well CC-10 and time for aquifer test of well CC-16, May 14-15, 1996, Malvern TCE Site, Chester County,

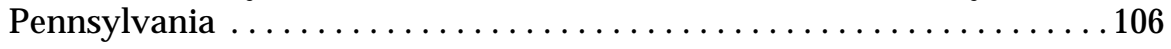




\section{FIGURES IN APPENDIX 4}

1-43. Graphs showing:

32. Relation between drawdown in well CC-18 and time for aquifer test of well CC-16, May 14-15, 1996, Malvern TCE Site, Chester County,

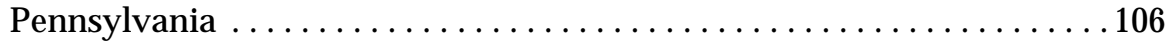

33. Relation between drawdown in well CC-5 and time for recovery phase of aquifer test of well CC-16, May 15, 1996, Malvern TCE Site, Chester County, Pennsylvania.

34. Relation between drawdown in well CC-9 and time for recovery phase of aquifer test of well CC-16, May 15, 1996, Malvern TCE Site, Chester County, Pennsylvania.

35. Relation between drawdown in well CC-10 and time for recovery phase of aquifer test of well CC-16, May 15, 1996, Malvern TCE Site, Chester County, Pennsylvania.

36. Relation between drawdown in well CC-17 and time for recovery phase of aquifer test of well CC-16, May 15, 1996, Malvern TCE Site, Chester County, Pennsylvania.

37. Relation between drawdown in well CC-18 and time for recovery phase of aquifer test of well CC-16, May 15, 1996, Malvern TCE Site, Chester County, Pennsylvania.

38. Relation between drawdown in well CC-5 and time for recovery phase of aquifer test of well CC-17, May 17, 1996, Malvern TCE Site, Chester County, Pennsylvania.

39. Relation between drawdown in well CC-9 and time for recovery phase of aquifer test of well CC-17, May 17, 1996, Malvern TCE Site, Chester County, Pennsylvania........................... 110

40. Relation between drawdown in well CC-10 and time for recovery phase of aquifer test of well CC-17, May 17, 1996, Malvern TCE Site, Chester County, Pennsylvania.

41. Relation between drawdown in well CC-15 and time for recovery phase of aquifer test of well CC-17, May 17, 1996, Malvern TCE Site, Chester County, Pennsylvania........................... 111

42. Relation between drawdown in well CC-16 and time for recovery phase of aquifer test of well CC-17, May 17, 1996, Malvern TCE Site, Chester County, Pennsylvania.

43. Relation between drawdown in well CC-18 and time for recovery phase of aquifer test of well CC-17, May 17, 1996, Malvern TCE Site, Chester County, Pennsylvania. 


\section{TABLES}

1. Record of wells at the Malvern TCE Site, Chester County, Pennsylvania .........6

2. Specific capacity from aquifer tests, Malvern TCE Site, Chester County,

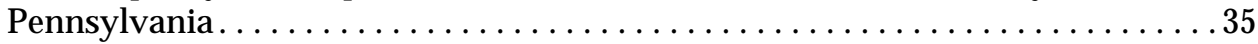

3. Measured drawdown and estimated transmissivity for the aquifer test of well CC-19, May 21-22, 1996, Malvern TCE Site, Chester County,

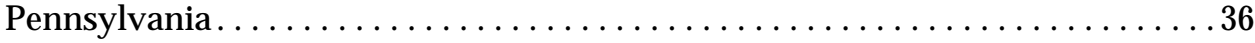

4. Measured drawdown and estimated transmissivity for the aquifer test of well CC-21, May 23-24, 1996, Malvern TCE Site, Chester County,

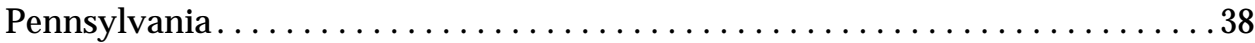

5. Results of chemical analyses for selected volatile organic compounds detected in water samples from on-site wells, 1996, Malvern TCE Site, Chester County, Pennsylvania ................................... 41

6. Measured drawdown and estimated transmissivity for aquifer test of well CC-16, May 14-15, 1996, Malvern TCE Site, Chester County,

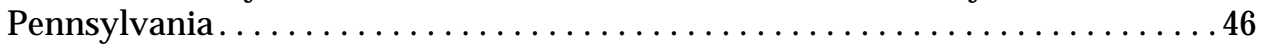

7. Measured drawdown for aquifer test of well CC-17, May 16-17, 1996, Malvern TCE Site, Chester County, Pennsylvania .................... 48

8. Results of chemical analyses for selected volatile organic compounds detected in water samples from off-site wells, 1995, Malvern TCE Site, Chester County,

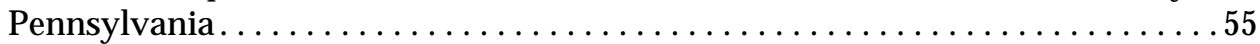

\section{TABLE IN APPENDIX 1}

1. Record of off-site wells near the Malvern TCE Site, Chester County,

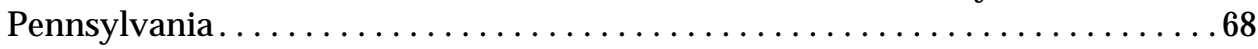

\section{TABLES IN APPENDIX 2}

1-8. Geologic log for wells at the Malvern TCE Site, Chester County, Pennsylvania:

1. CC-15 . . . . . . . . . . . . . . . . . . . . . . . . . . . . . . 72

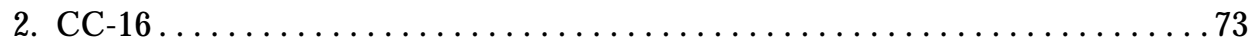

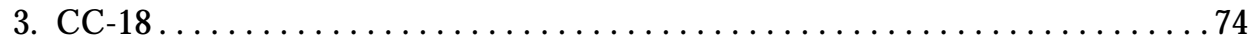

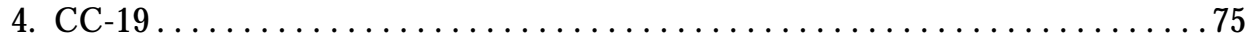

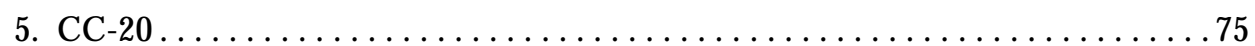

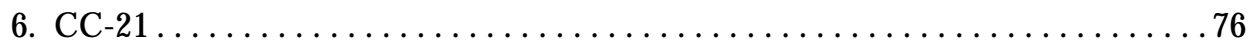

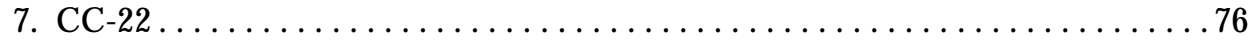

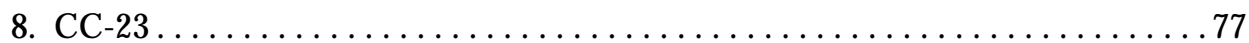




\section{TABLES IN APPENDIX 5}

1. Water levels (depth below land surface) measured monthly at the Malvern TCE Site, Chester County, Pennsylvania .................. 114

2. Water levels (altitude above sea level) measured monthly at the Malvern TCE Site, Chester County, Pennsylvania .................. 115

\section{TABLES IN APPENDIX 6}

1-3. Results of chemical analyses for volatile organic compounds in water samples from:

1. On-site wells sampled by the U.S. Geological Survey, Malvern TCE Site, Chester County, Pennsylvania ................ 118

2. On-site wells, Malvern TCE Site, Chester County, Pennsylvania. . . . . . . . 120

3. Off-site wells, Malvern TCE Site, Chester County, Pennsylvania . . . . . . . 123 


\section{CONVERSION FACTORS AND ABBREVIATIONS}

$\underline{\text { MULTIPLY }}$

LENGTH

inch (in.)

inch per year (in/yr)

foot $(\mathrm{ft})$

mile (mi)

foot squared per day $\left(\mathrm{ft}^{2} / \mathrm{d}\right)$ $\underline{\text { BY }}$

25.4

25.4

0.3048

1.609

0.0929

square mile $\left(\mathrm{mi}^{2}\right)$

Volume

gallon (gal)

FLOW

gallon per minute (gal/min)

million gallon per day (Mgal/d)

\section{TO OBTAIN}

\section{millimeter}

millimeter per year

meter

kilometer

meter squared per day

square kilometer

liter

0.06309

0.04381

liter per second

cubic meter per second

liter per second per meter

SPECIFIC CAPACITY

gallon per minute per foot $[(\mathrm{gal} / \mathrm{min}) / \mathrm{ft}] \quad 0.207$

TeMPERATURE

degree Fahrenheit $\left({ }^{\circ} \mathrm{F}\right)$

${ }^{\circ} \mathrm{C}=5 / 9\left({ }^{\circ} \mathrm{F}-32\right)$

degree Celsius

WeIGHT

pound (lb)

0.4536

kilogram

Sea level: In this report, "sea level" refers to the National Geodetic Vertical Datum of 1929-a geodetic datum derived from a general adjustment of the first-order level nets of the United States and Canada, called Sea Level of 1929.

Abbreviated water-quality unit used in report: $(\mu \mathrm{g} / \mathrm{L})$ micrograms per liter 


\title{
HYDROGEOLOGIC INVESTIGATION OF THE MALVERN TCE SUPERFUND SITE, Chester County, Pennsylvania
}

\author{
By Ronald A. Sloto
}

\begin{abstract}
The Malvern TCE Superfund Site, a former solvent recycling facility that now stores and sells solvents, consists of a plant and disposal area, which are approximately 1,900 ft (feet) apart. The site is underlain by an unconfined carbonate bedrock aquifer in which permeability has been enhanced in places by solution. Water levels respond quickly to precipitation and show a similar seasonal variation, response to precipitation, and range of fluctuation. The altitude of water levels in wells at the disposal area is nearly identical because of the small hydraulic gradient. A comparison of water-table maps for 1983, 1993, and 1994 shows that the general shape of the water table and hydraulic gradients in the area have remained the same through time and for different climatic conditions.
\end{abstract}

ABSTRACT

The plant area is underlain by dolomite of the Elbrook Formation. The dolomite at the plant area does not yield as much water as the dolomite at the disposal area because it is less fractured, and wells penetrate few water-bearing fractures. Yields of nine wells at the plant area range from 1 to $200 \mathrm{gal} / \mathrm{min}$ (gallons per minute); the median yield is $6 \mathrm{gal} / \mathrm{min}$. Specific capacities range from 0.08 to 2 (gal/min)/ft (gallons per minute per foot). Aquifer tests were conducted in two wells; median transmissivities estimated from the aquifer-test data ranged from 528 to 839 feet squared per day. Maximum concentrations of volatile organic compounds (VOC's) in ground water at the plant area in 1996 were 53,900 $\mu \mathrm{g} / \mathrm{L}$ (micrograms per liter) for trichloroethylene (TCE), $7,110 \mu \mathrm{g} / \mathrm{L}$ for tetrachloroethylene (PCE), and 17,700 $\mu \mathrm{g} / \mathrm{L}$ for 1,1,1-trichloroethane (TCA).

A ground-water divide is located between the plant area and the disposal area. Ground-water withdrawal for dewatering the Catanach quarry has caused a cone of depression in the water-table surface that reaches to the plant area. From the plant area, ground water flows 1.2 miles to the northeast and discharges to the Catanach quarry. The regional hydraulic gradient between the plant and the Catanach quarry is 0.019. Concentrations of $V O C$ 's in water from wells drilled northeast and downgradient of the plant property boundary are one to two orders of magnitude less than concentrations in water from wells less than $100 \mathrm{ft}$ away at the plant.

A capture-zone analysis was performed for two wells at the plant area. The analysis showed that pumping well CC-19 at $20 \mathrm{gal} / \mathrm{min}$ would be sufficient to capture all ground-water flow from the plant area. Although water from other wells at the plant site contains higher concentrations of VOC's than water from well CC-19, pumping well CC-19 would induce the flow of water with higher concentrations of VOC's; however, pumping well CC-19 might cause VOC's to move lower into the aquifer. 
The disposal area is underlain by the Ledger Dolomite. The dolomite at the disposal area is much more fractured than the dolomite at the plant area. Although many of the fractures are filled or partially filled with clay, the dolomite at the disposal area yields more water than the dolomite at the plant area. Yields of eight wells at the disposal area range from 15 to more than $200 \mathrm{gal} / \mathrm{min}$; the median yield is greater than $100 \mathrm{gal} / \mathrm{min}$. Specific capacities range from 2 to $280(\mathrm{gal} / \mathrm{min}) / \mathrm{ft}$. Aquifer tests were conducted in two wells; estimated transmissivities were 34,900 and 56,200 feet squared per day. Concentrations of VOC's in ground water are lower at the disposal area than at the plant area. Water samples collected from wells at the disposal area in $1996 \mathrm{had}$ maximum concentrations of TCE of $768 \mu \mathrm{g} / \mathrm{L}$, PCE of $111 \mu \mathrm{g} / \mathrm{L}$, and TCA of $108 \mu \mathrm{g} / \mathrm{L}$. These concentrations are lower than concentrations in water samples collected before cleanup of drums in the disposal area was completed in 1984.

Ground water from the disposal area flows southsoutheast toward Valley Creek. The hydraulic gradient between the disposal area and Valley Creek is 0.001. A well-defined plume of VOC's in ground water extends downgradient from the disposal area toward Valley Creek. A comparison of data from 1995 to 1996 with data from 1981 to 1984 shows that concentrations of TCE, PCE, and TCA in water from most off-site wells have decreased and that water from fewer wells contains detectable concentrations of those compounds.

A capture-zone analysis was performed for three wells at the disposal area. The analysis showed that pumping wells CC-16, CC-17, and CC-18 at a combined rate of $270 \mathrm{gal} / \mathrm{min}$ would form a capture zone ranging from approximately 443 to $477 \mathrm{ft}$ wide at a distance $500 \mathrm{ft}$ upgradient from the center of the pumping wells. Pumping wells CC-16 and CC-17 together at a combined rate of $172 \mathrm{gal} / \mathrm{min}$ would form a capture zone ranging from approximately 172 to $400 \mathrm{ft}$ wide at a distance $500 \mathrm{ft}$ upgradient from the center of the pumping wells.

\section{INTRODUCTION}

The Malvern TCE Superfund Site is in East Whiteland Township, Chester County, Pa. (fig. 1). The site is an active facility operated by the Chemclene Corporation since about 1950 . Chemclene recycled and sold the solvents trichloroethylene (TCE), tetrachloroethylene (PCE), 1,1,1-trichloroethane (TCE), and methylene chloride (Dames and Moore, Inc., 1989, p. 2) until 1993 when Chemclene withdrew its permit that allowed the company to treat and store hazardous waste. Chemclene currently accepts hazardous materials in bulk quantities and repackages the material for sale in smaller quantities. Chemclene currently has a permit with the East Whiteland Township Fire Marshall's Office to manufacture, use, store, or sell acetone, methanol, isopropanol, toluene, mineral spirits, methyl ethyl ketone, fuel oil, diesel fuel, TCE, methylene chloride, PCE, and hydrogen peroxide (L.R. Dietz, U.S. Environmental Protection Agency, written commun., 1996).

The site consists of two separate areas: the plant area and the former disposal area/mounded area, which is called the disposal area in this report. The plant area includes the distillation building, an adjoining storage building, a concrete storage pad, an aboveground storage tank area, a garage, and a former underground storage tank area. The disposal area is approximately $1,900 \mathrm{ft}$ west of the plant area (fig. 2). The disposal area once contained two earthen disposal impoundments, each measuring approximately $30 \mathrm{ft}$ by $50 \mathrm{ft}$ by $15 \mathrm{ft}$ deep. This area is now secured by an 8 -ft-high chain link fence. The mounded area is approximately $8 \mathrm{ft}$ wide by $150 \mathrm{ft}$ long and is west of the disposal area. It was used to dispose of drummed distillation residue from Chemclene's solvent recycling process (CH2M HILL, Inc., 1995, p. 1-2). The Transcontinental Gas Company pipeline is south of and approximately parallel to the site.

Until 1976, the Chemclene Corporation disposed of drummed distillation residue in two earthen impoundments at the disposal area. From 1981 to 1984, the Chemclene Corporation voluntarily performed a clean up of the disposal area under the oversight of the Pennsylvania Department of Environmental Protection (PaDEP). All drums and soil to a depth of $15 \mathrm{ft}$ were removed. Buried drums of distillation residue were removed from the mounded area (Dames and Moore, Inc., 1989, p. 4-5). Another cache of drums was discovered in the mounded area in 1990 and removed. However, contaminated soil remains in place in the mounded area.

South and southwest of the disposal area, the Hillbrook Circle residential development (fig. 1) is supplied with water by domestic wells. The residential area surrounding the plant area is supplied by public water. Northeast of the site is the active (1996) Catanach quarry. 


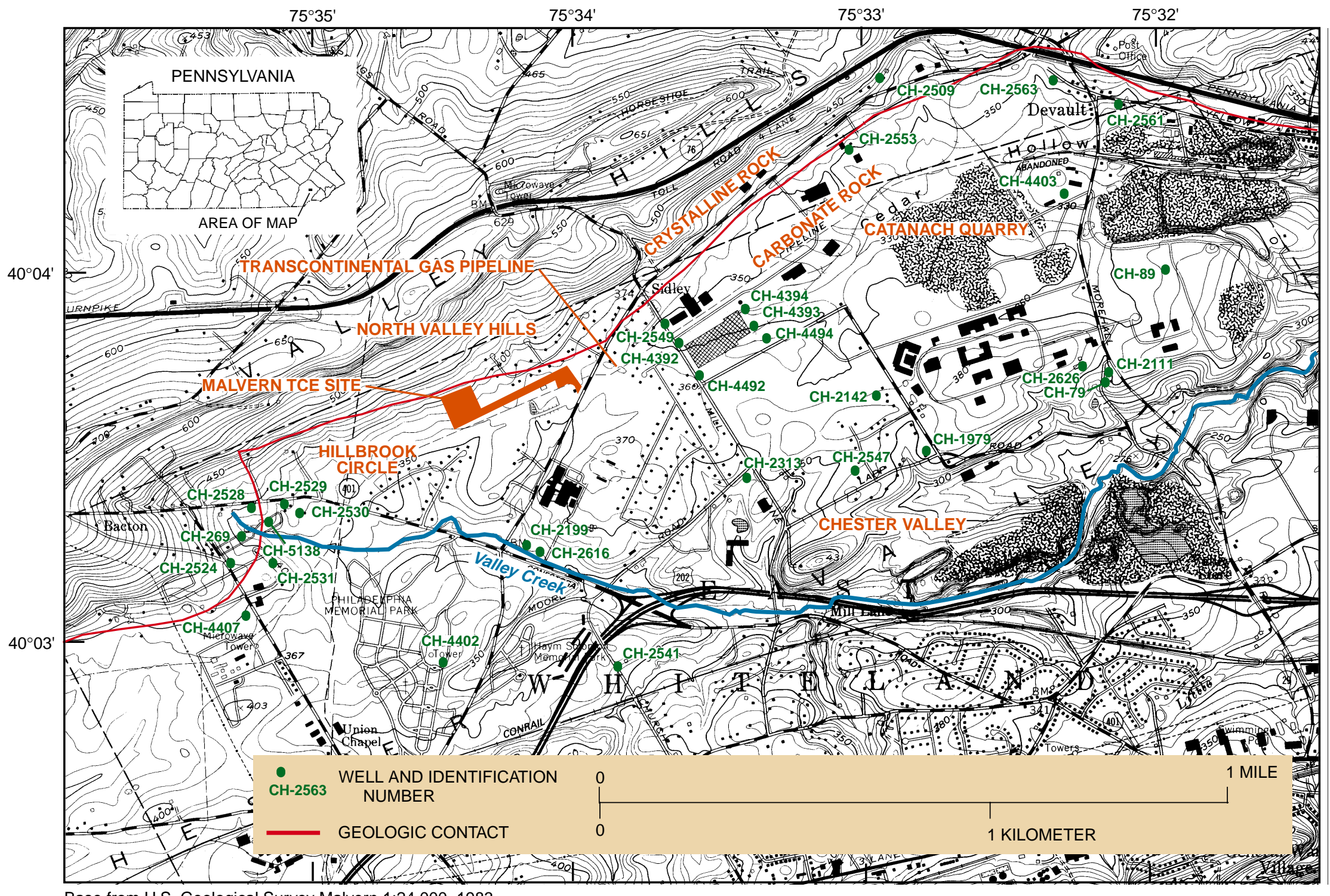

Figure 1. Location of the Malvern TCE Site and selected wells, Chester County, Pennsylvania. 


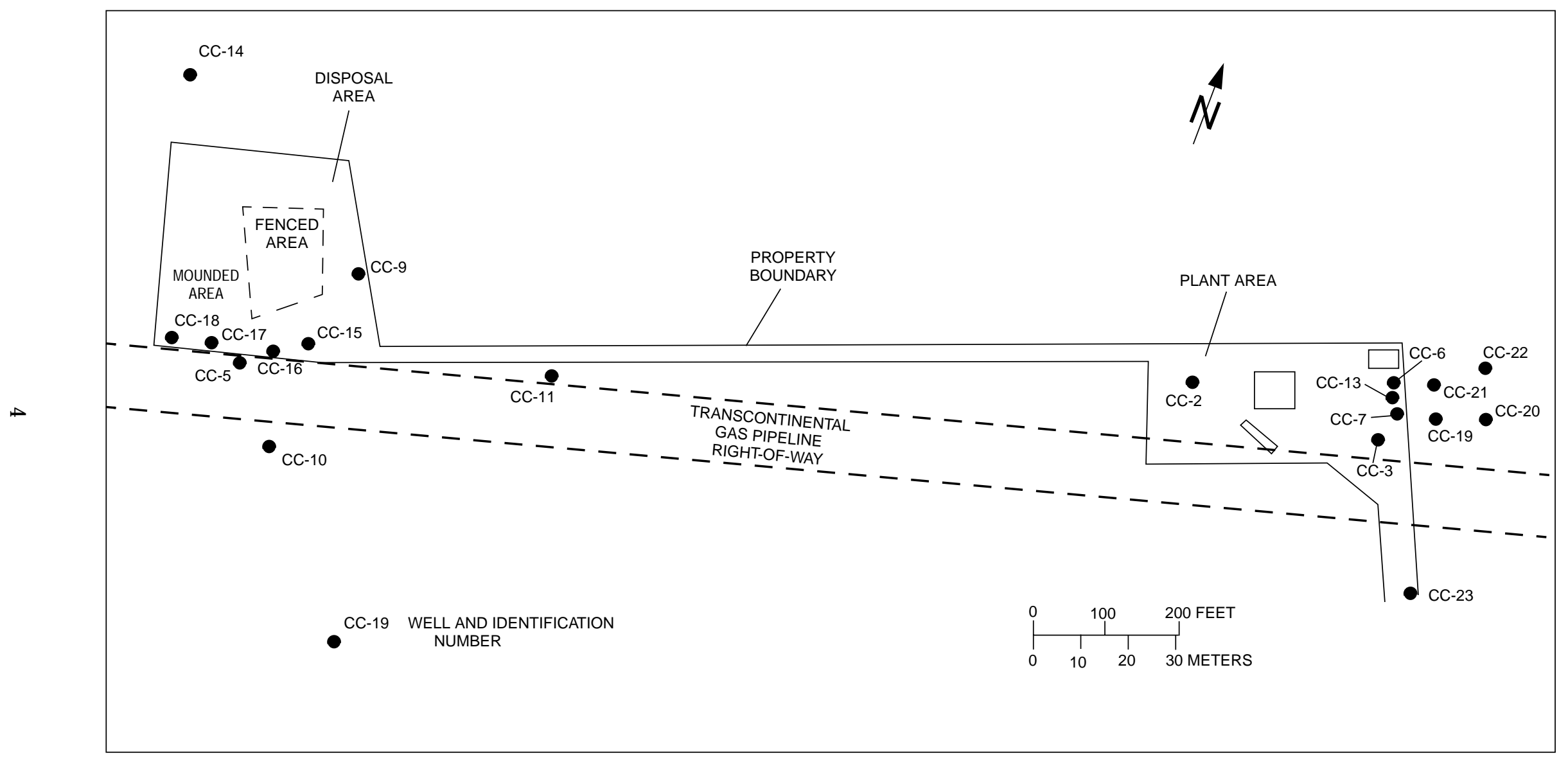

Figure 2. Location of wells at the Malvern TCE Site, Chester County, Pennsylvania. 
In 1980-81, the PaDEP and the Chemclene Corporation sampled on-site monitor wells and nearby domestic wells. The sampling identified contamination of ground water by volatile organic compounds (VOC's). On December 1, 1982, the site was placed on the National Priorities List (NPL) as the Malvern TCE Site. On December 16, 1988, the Chemclene Corporation entered into a Consent Order with the Resource and Recovery Act (RCRA) Branch of the U.S. Environmental Protection Agency (USEPA) in which Chemclene agreed to perform a RCRA Facility Investigation (RFI) and Corrective Measures Study (CMS) (U.S. Environmental Protection Agency, 1992, p. 118-119). The site was transferred to the Superfund program in November 1993. Although soil and ground-water data were gathered during the RFI, a complete characterization of the site is unavailable. Therefore, this investigation by the U.S. Geological Survey (USGS) was undertaken in cooperation with the USEPA.

\section{Purpose AND SCOPE}

This report describes the hydrogeology of the Malvern TCE Site. The purpose of this report is to: (1) characterize the hydrology and geology in the vicinity of the site, (2) describe the range and magnitude of water-level fluctuations, (3) define hydraulic gradients in the vicinity of the site, (4) characterize the horizontal extent of ground-water contamination by VOC's, (5) describe aquifer properties, (6) describe ground-water flow in the vicinity of the site, and (7) describe the probable effects of pumping wells installed at the site for this investigation.

\section{PHYSIOGRAPHY AND CLIMATE}

The Malvern TCE Site is located in the Valley Creek Basin in eastern Chester County in southeastern Pennsylvania (fig. 1). Valley Creek, a tributary to the Schuylkill River, is a subbasin in the lower Delaware River Basin. The center of the Valley Creek Basin is underlain mostly by easily eroded limestone and dolomite, which form the Chester Valley (fig. 1). Chester Valley trends east-northeast across Chester County. The northern part of the Valley Creek Basin is underlain by resistant quartzites and gneiss that form the North Valley Hills, which rise about $400 \mathrm{ft}$ above the gently rolling valley floor.

The climate in Chester County is a humid, modified continental climate characterized by warm summers and moderately cold winters. The normal
(1961-90) mean annual temperature at Phoenixville, about $5 \mathrm{mi}$ north-northeast of the site, is $51.7^{\circ} \mathrm{F}$. The normal (1961-90) mean temperature for January, the coldest month, is $28^{\circ} \mathrm{F}$, and the normal mean temperature for July, the warmest month, is $73.8^{\circ} \mathrm{F}$. The normal (1961-90) annual precipitation at Phoenixville is 42.56 in. (Owenby and Ezell, 1992). Precipitation is about evenly distributed throughout the year, with slightly more occurring during the warmer months because of localized thunderstorms.

\section{WELL-NUMBERING SYSTEM}

Three well-identification numbering systems are used in this report so that identifiers are consistent with previous site work. Site well-identification numbers consist of the prefix CC followed by a sequentially-assigned number. Off-site domestic wellidentification numbers consist of the prefix DW followed by a sequentially-assigned number. USGS well-identification numbers, which consist of the county abbreviation prefix $\mathrm{CH}$ followed by a sequentially-assigned number, are used for all other wells. Data for site wells are given in table 1. Data for off-site wells are given in appendix 1 . The tables provide a cross reference between USGS, site, and offsite well-identification numbers. Locations of on-site wells are shown on figure 2; locations of off-site wells are shown on figures 1 and 3.

\section{Previous InVestigations}

The geology of the area was mapped and described by Bascom and Stose (1938). The area is included on the geologic map of Lyttle and Epstein (1987).

Sloto (1987) described the effect of urbanization on the water resources of eastern Chester County. Sloto (1989) presented ground-water data for Chester County. Sloto (1990) used a digital computer model to simulate ground-water flow and the water budget of the Valley Creek Basin. Sloto (1994) described the ground-water resources of Chester County. Watertable maps of the area are presented for October 1983 by Sloto (1987, pl. 2), for May and June 1993 by McManus and Sloto (1993), and for December 6, 1994, by McManus and Sloto (1996). 
Table 1. Record of wells at the Malvern TCE Site, Chester County, Pennsylvania

[Locations of wells are shown on figure 2; LS, land surface; gal/min, gallons per minute;

MSL, mean sea level; OH, open-hole construction; PVC, polyvinyl chloride; --, no data; >, greater than]

\begin{tabular}{|c|c|c|c|c|c|c|c|c|c|c|c|}
\hline $\begin{array}{l}\text { Site well- } \\
\text { identification } \\
\text { number }\end{array}$ & $\begin{array}{c}\text { U.S. } \\
\text { Geological } \\
\text { Survey } \\
\text { well- } \\
\text { identification } \\
\text { number }\end{array}$ & $\begin{array}{c}\text { Well } \\
\text { depth } \\
\text { drilled } \\
\text { (feet) }\end{array}$ & $\begin{array}{c}\text { Well } \\
\text { depth } \\
\text { measured } \\
\text { (feet) }\end{array}$ & $\begin{array}{c}\text { Well } \\
\text { diameter } \\
\text { (inches) }\end{array}$ & $\begin{array}{c}\text { Casing } \\
\text { diameter } \\
\text { (inches) } \\
\text { and material }\end{array}$ & $\begin{array}{l}\text { Casing } \\
\text { length } \\
\text { (feet) }\end{array}$ & $\begin{array}{c}\text { Open or } \\
\text { screened } \\
\text { interval (feet } \\
\text { below LS) }\end{array}$ & $\begin{array}{c}\text { Reported } \\
\text { yield } \\
\text { (gal/min) }\end{array}$ & $\begin{array}{l}\text { Depth to } \\
\text { water (feet } \\
\text { below } \\
\text { LS) }\end{array}$ & $\begin{array}{c}\text { Land } \\
\text { surface } \\
\text { elevation } \\
\text { (feet above } \\
\text { MSL) }\end{array}$ & $\begin{array}{c}\text { Water level } \\
\text { elevation } \\
\text { (feet above } \\
\text { MSL) }\end{array}$ \\
\hline \multicolumn{12}{|l|}{ Plant area } \\
\hline CC-2 & $\mathrm{CH}-5119$ & 110 & 103 & 6 & 6 steel & 63 & $\mathrm{OH}$ & -- & 60.17 & ${ }^{2} 369.62$ & 309.25 \\
\hline CC-3 & $\mathrm{CH}-2672$ & 101 & 102 & 4 & $\begin{array}{l}6 \text { steel } \\
4 \text { PVC }\end{array}$ & $\begin{array}{l}83.5 \text { steel } \\
--\end{array}$ & -- & 6 & 69.96 & 2376.20 & 306.24 \\
\hline CC-6 & $\mathrm{CH}-4405$ & 115 & 112 & 4 & $\begin{array}{l}6 \text { steel } \\
4 \text { PVC }\end{array}$ & $\begin{array}{r}62 \text { steel } \\
104 \text { PVC }\end{array}$ & $104-114$ & 10 & 72.69 & 2376.53 & 303.84 \\
\hline CC-7 & $\mathrm{CH}-4398$ & 120 & 107.4 & 6 & 6 steel & 82 & $\mathrm{OH}$ & 1 & 71.82 & ${ }^{2} 377.41$ & 305.59 \\
\hline CC-13 & $\mathrm{CH}-4404$ & 180 & 178 & 6 & $\begin{array}{l}8 \text { steel } \\
6 \text { steel }\end{array}$ & $\begin{array}{r}58 \\
123\end{array}$ & $\mathrm{OH}$ & 5 & 72.59 & 2377.94 & 305.35 \\
\hline CC-19 & $\mathrm{CH}-5146$ & 303 & 303 & 4 & $\begin{array}{c}16 \text { steel } \\
10 \text { steel } \\
4 \text { PVC }\end{array}$ & $\begin{array}{r}21 \\
68 \\
140\end{array}$ & $140.2-180.2$ & 25 & 71.31 & ${ }^{3} 376.07$ & 304.76 \\
\hline CC-20 & $\mathrm{CH}-5147$ & 303 & 303 & 4 & $\begin{array}{c}16 \text { steel } \\
10 \text { steel } \\
4 \text { PVC }\end{array}$ & $\begin{array}{r}7 \\
106 \\
243\end{array}$ & $243-253$ & 5 & 70.69 & ${ }^{3} 375.36$ & 304.67 \\
\hline CC-21 & $\mathrm{CH}-5148$ & 185 & 113.5 & 4 & $\begin{array}{r}16 \text { steel } \\
10 \text { steel } \\
8 \text { steel } \\
4 \text { PVC }\end{array}$ & $\begin{array}{l}15 \\
45 \\
73 \\
99\end{array}$ & $99-109$ & 20 & 73.54 & ${ }^{3} 377.48$ & 303.94 \\
\hline CC-22 & $\mathrm{CH}-5149$ & 303 & 132 & 4 & $\begin{array}{c}16 \text { steel } \\
10 \text { steel } \\
4 \text { PVC }\end{array}$ & $\begin{array}{c}21 \\
104 \\
103.5\end{array}$ & $103.5-113.5$ & 2 & 70.07 & ${ }^{3} 378.28$ & 308.21 \\
\hline CC-23 & $\mathrm{CH}-5482$ & 282 & 259.3 & 2 & $\begin{array}{c}10 \text { steel } \\
2 \text { PVC } \\
2 \text { PVC }\end{array}$ & $\begin{array}{c}83 \\
95.5 \\
249.3\end{array}$ & $\begin{array}{c}95.5-105.5 \\
249.3-259.3\end{array}$ & 200 & -- & -- & -- \\
\hline \multicolumn{12}{|c|}{ Disposal area } \\
\hline CC-5 & $\mathrm{CH}-5121$ & 70 & 80 & 4 & $\begin{array}{l}6 \text { steel } \\
4 \text { PVC }\end{array}$ & $\begin{array}{l}64 \text { steel } \\
--\end{array}$ & -- & -- & 44.86 & ${ }^{2} 363.91$ & 319.05 \\
\hline CC-9 & $\mathrm{CH}-4396$ & 105 & 114 & 8 & 8 steel & 100 & $\mathrm{OH}$ & 100 & 56.77 & 2377.71 & 318.94 \\
\hline CC-10 & $\mathrm{CH}-5122$ & 135 & 134.6 & 2 & $\begin{array}{r}10 \text { steel } \\
8 \text { steel } \\
6 \text { steel } \\
2 \text { PVC }\end{array}$ & $\begin{array}{c}5 \text { steel } \\
60.5 \text { steel } \\
124 \text { steel } \\
124.6 \text { PVC }\end{array}$ & 124.6-134.6 & 75 & 39.93 & ${ }^{2} 358.87$ & 318.94 \\
\hline CC-11 & $\mathrm{CH}-5123$ & 191 & 127 & 6 & $\begin{array}{l}8 \text { steel } \\
6 \text { steel }\end{array}$ & $\begin{array}{r}88 \\
124\end{array}$ & $\mathrm{OH}$ & 130 & 49.57 & 2369.09 & 319.52 \\
\hline CC-14 & $\mathrm{CH}-5124$ & 145 & 129 & 6 & $\begin{array}{l}6 \text { steel } \\
4 \text { PVC }\end{array}$ & $\begin{array}{l}120 \text { steel } \\
125 \text { PVC }\end{array}$ & $\mathrm{OH}$ & 15 & 71.22 & 2390.50 & 319.28 \\
\hline CC-15 & $\mathrm{CH}-5142$ & 159 & 139 & 6 & $\begin{array}{c}16 \text { steel } \\
10 \text { steel } \\
6 \text { PVC }\end{array}$ & $\begin{array}{r}40 \\
129 \\
129\end{array}$ & $129-139$ & $>200$ & 47.20 & ${ }^{3} 365.19$ & 317.99 \\
\hline CC-16 & $\mathrm{CH}-5143$ & 150 & 129.1 & 6 & $\begin{array}{c}16 \text { steel } \\
10 \text { steel } \\
6 \text { PVC }\end{array}$ & $\begin{array}{r}43 \\
119 \\
119\end{array}$ & 119.1-129.1 & $>100$ & 46.93 & ${ }^{3} 365.13$ & 318.20 \\
\hline CC-17 & $\mathrm{CH}-5144$ & 140 & 115.5 & 6 & $\begin{array}{c}16 \text { steel } \\
10 \text { steel } \\
6 \text { PVC }\end{array}$ & $\begin{array}{c}21 \\
105 \\
105.5\end{array}$ & $105.5-115.5$ & $>200$ & 47.70 & ${ }^{3} 365.95$ & 318.25 \\
\hline CC-18 & $\mathrm{CH}-5145$ & 205 & 194 & 4 & $\begin{array}{r}16 \text { steel } \\
10 \text { steel } \\
8 \text { steel } \\
4 \text { PVC }\end{array}$ & $\begin{array}{r}7 \\
113 \\
184 \\
184 \\
\end{array}$ & 184-194 & $>200$ & 47.92 & ${ }^{3} 365.19$ & 317.27 \\
\hline
\end{tabular}

\footnotetext{
${ }^{1}$ Measured on May 30, 1996.

2 Surveyed by the U.S. Geological Survey.

${ }^{3}$ Survey data provided by CH2M HILL, Inc. (written commun., 1996).
} 


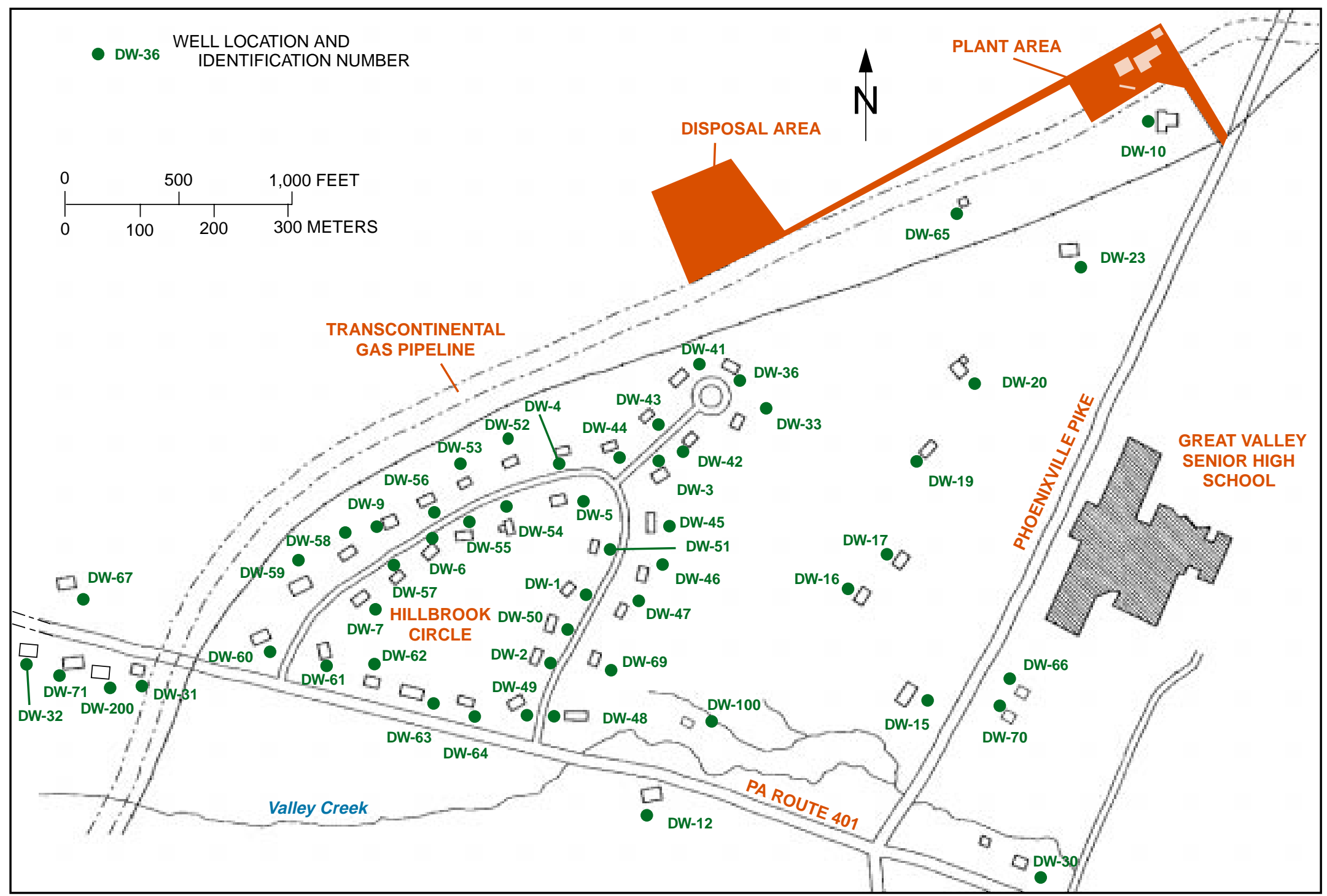

Figure 3. Location of domestic wells near the Malvern TCE Site, Chester County, Pennsylvania. 
Site reports describing ground water prepared by environmental consulting firms include a report by Moorshead-Siddiqui and Associates (1982), reports and workplans by Earth Data, Inc. (1984, 1986, 1991, 1992), workplans by Dames and Moore, Inc. (1989a, 1989b), a data report by CH2M HILL, Inc. (1995), and a remedial investigation report by $\mathrm{CH} 2 \mathrm{M}$ HILL, Inc. (1997). Ground-water reports submitted to the USEPA by the Chemclene Corporation include Chemclene Corporation $(1992,1993)$.

\section{ACKNOWLEDGMENTS}

The author gratefully acknowledges W. Lloyd Balderston of the Chemclene Corporation and East Whiteland Township for allowing the drilling and testing of wells on their property, well owners that permitted water-level measurements for the watertable map, and well owners that permitted daily water-level measurements during aquifer tests. The author acknowledges Philip H. Bird for his assistance with well drilling, well construction, well development, borehole geophysical logging, and aquifer tests and Kevin E. Grazul for his assistance with well development and aquifer tests. Philip $\mathrm{H}$. Bird ran X-ray diffraction analyses on drill cuttings using equipment at the West Chester University Department of Geology. The author also acknowledges the Report Team for this project, who was instrumental in the planning and technical review of this report: Linda R. Dietz and Barbara J. Rudnick of the USEPA and James M. Gerhart, Dennis J. Low, Dennis W. Risser, Kim L. Wetzel, Charles R. Wood, and Richard M. Yager of the USGS.

\section{METHODS OF INVESTIGATION}

\section{BOREHOLE GEOPHYSICS}

Caliper, natural-gamma, single-pointresistance, fluid-resistivity, and (or) fluid-temperature logs were run in four existing wells and nine wells drilled for this investigation.

Caliper logs provide a continuous record of average borehole diameter, which is related to fractures, lithology, and drilling technique. Caliper logs are used to identify fractures and possible waterbearing openings. Correlation of caliper logs with fluid-resistance and fluid-temperature logs was used to identify fractures and water-producing and waterreceiving zones.
Natural-gamma logs, also called gamma-ray logs, record the natural-gamma radiation emitted from rocks penetrated by the borehole. Gamma radiation can be measured through casing, but the gamma response is dampened by steel casing. Uranium-238, thorium-232, the progeny of their decay series, and potassium- 40 are the most common emitters of natural-gamma radiation. These radioactive elements may be concentrated in clay by adsorption and ion exchange; therefore, clay usually emits more gamma radiation than does dolomite. Natural-gamma logs were used to differentiate between clay-rich unconsolidated and consolidated materials.

Single-point-resistance logs record the electrical resistance between the borehole and an electrical ground at land surface. In general, resistance increases with grain size and decreases with borehole diameter, density of water-bearing fractures, and increasing dissolved-solids concentration of borehole fluid (Keys, 1990). A fluid-filled borehole is required for single-point-resistance logs, and they are run only for the saturated part of the formation below the casing.

Fluid-resistivity logs measure the electrical resistance of fluid in the borehole. Resistivity is the reciprocal of fluid conductivity, and fluid-resistivity logs reflect changes in the dissolved-solids concentration of the borehole fluid. Fluid-resistivity logs were used to identify water-producing and water-receiving zones and to determine intervals of vertical borehole flow. Water-producing and waterreceiving zones usually are identified by sharp changes in resistivity, and intervals of borehole flow are identified by a low resistivity gradient between water-producing and water-receiving zones.

Fluid-temperature logs provide a continuous record of the temperature of the fluid in the borehole. Temperature logs were used to identify waterproducing and water-receiving zones and to determine intervals of vertical borehole flow. Waterproducing and water-receiving zones usually are identified by sharp changes in temperature.

The rate and direction of borehole-fluid movement was determined in borehole CC-19 using a heat-pulse flowmeter. The heat-pulse flowmeter operates by slightly heating a small sheet of water between two sensitive thermistors, one below and one above the heating grid. A measurement of direction and flow rate is computed when a peak temperature 
is recorded by one of the thermistors. The range of measurable flow is 0.01 to $1.0 \mathrm{gal} / \mathrm{min}$ in a 2- to 10-in.-diameter borehole.

Borehole television surveys were conducted in selected boreholes by lowering a waterproof video camera with a wide angle lens down the borehole and recording the images on videotape. Borehole television surveys were used to aid interpretation of geophysical logs.

\section{WELl DRILLING AND CONSTRUCTION}

Locations for wells drilled for this study were chosen on the basis of ground-water-flow paths determined from the water-table map (pl. 1). Eight wells were drilled between October 1995 and March 1996. A ninth well (CC-23) was drilled in September 1996. In the disposal area, four wells (CC-15, CC-16, CC-17, and CC-18) were drilled downgradient of the fenced area in a line just north of the Transcontinental Gas pipeline right-of-way. At the plant area, four wells (CC-19, CC-20, CC-21, and CC-22) were drilled on the property owned by East Whiteland Township adjacent to and downgradient from the plant, and one well (CC-23) was drilled on Chemclene Corporation property near Phoenixville Pike.

The wells were drilled by an air rotary drilling rig. The wells were cased with 10-in.-diameter steel casing. A small quantity of potable water was added during drilling to prevent mudcaking if formation water production was insufficient. The quantity of water produced from each water-bearing zone during drilling was estimated. Water was blown from the well by compressed air, and the total well yield was estimated after completion of drilling. Each well initially was developed by pumping with air pressure from the drilling rig for at least 30 minutes following completion of drilling. During drilling, composite samples of drill cuttings were collected for each 5 - $\mathrm{ft}$ interval. Geologic logs for each well are given in appendix 2. A geologic log is not available for well CC-17.

During drilling of wells at the disposal area and well CC-21 at the plant area, the formation was continually collapsing. To construct a monitor well, each well was cased to the bottom, and all loose material was blown out of the casing with compressed air. A layer of coarse sand was placed at the bottom of the borehole, and a 4- or 6-in.-diameter Schedule 40 polyvinyl chloride (PVC) flush joint threaded inner casing with a 0.020 -in. well screen and an end cap on the lower end was installed in the center of each well. A filter pack consisting of coarse sand was placed in the annulus from the bottom of the well to above the top of the screen. The casing was then pulled up to expose the screen. A bentonite seal was installed in the annulus above the filter pack, and the annulus was grouted to land surface with cement grout. Well-construction diagrams are presented in appendix 3 .

The other three wells at the plant area (CC-19, CC-20, and CC-22) were constructed in the following manner: An interval to be screened was selected on the basis of drilling data, borehole geophysical logs, borehole television surveys, aquifer-isolation test hydraulic data (CC-19 only), and (or) chemical data. The well was backfilled with bentonite to the bottom of the interval selected for screening. A layer of coarse sand was placed on top of the bentonite, and a 4-in.-diameter Schedule 40 PVC flush joint threaded inner casing with a 0.020-in. well screen and an end cap on the lower end was installed in the center of each well. A filter pack consisting of coarse sand was placed in the annulus from the top of the bentonite backfill to above the top of the screen. A bentonite seal was installed above the filter pack in the annulus, and the annulus was grouted to land surface with cement grout. Well-construction diagrams are presented in appendix 3 .

After each well was completed as a monitor well, it was further developed by pumping with a submersible pump. During development, measurements of yield using a flowmeter and drawdown using an electric tape and (or) a pressure transducer were made, and the specific capacity was calculated. Specific capacity is calculated by dividing pumping rate, in gallons per minute, by the drawdown, in feet.

\section{Hydraulic Tests}

Constant-discharge aquifer tests were used to determine aquifer transmissivity. For all tests, pressure transducers were installed in the pumped well and in all nearby observation wells to measure drawdown and recovery. Measurements from the transducers were recorded by a data logger at the surface. Electric-tape measurements were taken at irregular time intervals to verify transducer performance. A 5-horsepower submersible pump was set $10 \mathrm{ft}$ above the top of the screen in each well. Wells CC-16 and CC-17 were pumped at the maximum pump capacity. The pumping rate for wells CC-19 and 
CC-21 was determined by a step test the day before the aquifer test. All discharge water was pumped through a filtering system containing $4,000 \mathrm{lb}$ of granular activated carbon to remove VOC's and discharged to the land surface several hundred feet from the pumped well. The discharge water did not recharge the aquifer in the vicinity of the pumped well, and water levels were not affected during the aquifer tests.

For the aquifer tests of wells CC-16, CC-19, and CC-21, the semilogarithmic analytical methods of Cooper and Jacob (1946) and Theis (1935) for unsteady flow to a well in an unconfined aquifer were used to analyze drawdown and (or) recovery data. Fully penetrating pumping and observation wells were assumed.

The analytical method used to analyze aquifertest data assumes (1) an aquifer of infinite areal extent, (2) a homogeneous aquifer, (3) uniform aquifer thickness, (4) a constant pumping rate, (5) unsteady flow, and (6) the diameter of the pumping well is very small so that storage in the well can be neglected. An extensive aquifer (assumption 1) can be assumed because drawdown spatially affects only a small part of the aquifer. Saturated thickness is difficult to determine for a fractured-rock aquifer, but assumption 3 is considered met. Pumping rates were held constant (assumption 4) during the tests. Flow was unsteady (assumption 5). Assumption 6 is considered met because of the relatively high pumping rates and long duration of the tests. The aquifer is heterogeneous, and assumption 2 is not met; therefore, transmissivities are estimates.

To estimate transmissivity from drawdown data, the semilogarithmic method of Cooper and Jacob (1946) as applied by Neuman (1975, p. 331-332) to unconfined aquifers was applied to late-time data. Measured drawdown on a linear scale was plotted against time since the start of pumping on a logarithmic scale. A straight line was visually fitted through the late-time data, and the change in slope over one log cycle was determined. Transmissivity was estimated using the following equation:

$$
T=0.183 \frac{Q}{\Delta s_{L}}
$$

where $T$ is transmissivity, in feet squared per day, $Q$ is pumping rate, in cubic feet per day, and
$\Delta s_{L}$ is change in drawdown over one log cycle,
in feet.

Recovery data are generally more reliable than drawdown data because recovery takes place at a constant rate, while a constant pumping rate often is difficult to achieve, and well-bore storage is not a factor when only late-time data are considered. To estimate transmissivity from recovery data, the method of Theis (1935) was used. Drawdown since the cessation of pumping on a linear scale was plotted against the time in minutes since start of pumping divided by the time in minutes since cessation of pumping on a logarithmic scale. A straight line was visually fitted through the late-time data, and the change in slope over one log cycle was determined. Transmissivity was estimated from equation 1 .

For the aquifer test of well CC-17, the data were insufficient to calculate transmissivity using the semilogarithmic method. Therefore, the method of Theis and others (1963) for estimating transmissivity of an unconfined aquifer from specific capacity was used. Transmissivity was estimated from:

$$
T=\frac{Q}{s_{w}} \frac{2.30}{4 \pi} \log \frac{2.25 T t}{r_{w}^{2} S}
$$

where $s_{w}$ is drawdown, in feet, $t$ is pumping time, in days, $r_{w}$ is well radius, in feet, and $S$ is storage coefficient.

The storage coefficient was estimated to be 0.01 .

For the aquifer test of well CC-19, transmissivity was estimated from specific capacity using the method of Todd (1980, p. 155), which is equation 2 plus a well loss term:

$$
T=\frac{Q}{s_{w}} \frac{2.30}{4 \pi} \log \left(\frac{2.25 T t}{r_{w}^{2} S}\right)+C Q^{n-1}
$$

where $C Q$ is well loss, in feet, and $n$ is a constant.

$n$ was assumed to be 2 (Todd, 1980, p. 152). 
Well loss was estimated using the graphical method of Bierschenk (1963) by:

$$
C Q^{n}=\frac{s_{w}}{B Q}
$$

where $B Q$ is formation loss, in feet.

Formation loss was estimated to be $19.2 \mathrm{ft}$, and well loss was estimated to be $16.2 \mathrm{ft}$. A storage coefficient of 0.001 was used.

On May 2, 1996, an aquifer-isolation test, commonly known as a packer test, was conducted in well CC-19. An inflatable packer was used to isolate two discrete water-bearing intervals. The packer assembly was lowered with 2-in.-diameter drill-stem pipe, and the packer was inflated against the borehole wall, isolating the intervals. Inflation of the packers created two zones-an interval above the packer and an interval below the packer. Two measures were taken to ensure that the isolated intervals were hydraulically isolated from each other: First, packer inflation pressures were monitored continuously. They remained constant throughout each test. Second, water levels were monitored in both intervals.

After the packer was inflated, water levels in both zones were allowed to reach static levels. Water levels were measured by pressure transducers connected to a data logger and with electric measuring tapes. A submersible pump was suspended in each zone. When water levels stabilized, pumping began. First, the lower zone was pumped and allowed to recover. The water-level changes were recorded by the data logger. After recovery of the water levels, the upper zone was pumped. The water-level changes were recorded by the data logger. For both the upper and lower isolated-zone tests, specific capacities were determined at the end of the pumping period.

\section{CAPTURE-Zone ANALYSIS}

Approximate capture zones were estimated for selected wells installed by USGS using the semianalytical RESSQ computer code of Javandel, Doughty, and Tsang (1984), which is capable of determining capture zones created by multiple pumping wells. The model assumes steady-state uniform Darcy flow in a two-dimensional, heterogeneous, and isotropic system. For this analysis, a block of aquifer material is assumed to have the equivalent properties as the same size block of porous media. The aquifer tests indicate that the system responds to pumping as a porous media, and the water-table map (pl. 1) indicates that groundwater flow is continuous at a regional scale.

Theory and equations used to calculate streamlines and equipotentials are given by Javandel, Doughty, and Tsang (1984, p. 35-46) and are not repeated here. Input to the program includes the pumping rate, aquifer thickness (assumed to be $100 \mathrm{ft}$ ), and flux. Flux is calculated by:

$$
q=\frac{T I}{b}
$$

where $q$ is flux, in feet per day, $T$ is transmissivity, in feet squared per day, I is hydraulic gradient, and $b$ is aquifer thickness, in feet.

One-half of the available drawdown was multiplied by the specific capacity to determine a pumping rate $(Q)$ for the capture-zone analysis. Available drawdown was determined by subtracting the elevation of the bottom of the well screen from the elevation of the water level measured in the well prior to the aquifer tests. One-half of the available drawdown was chosen to provide a reliable long-term yield. The hydraulic gradient $(I)$ was calculated using water levels measured at the site in May 1996.

The dimensions of the capture zone generated by the computer code of Javandel, Doughty, and Tsang (1984) were transferred to the site map. The long axis of the capture zone was oriented parallel to the direction of ground-water flow determined from the water-table map (pl. 1).

\section{WATER-QUALITY SAMPLING AND ANALYSIS}

Water samples were collected by USGS with a submersible pump from the eight wells drilled between October 1995 and March 1996 for this study and analyzed for VOC's. Water samples were collected at the end of each aquifer-isolation test for well CC-19 to determine where to set the well screen, at the end of the development period for the other seven wells to help determine for which wells an aquifer test should be run, and at the end of each aquifer test for wells CC-16, CC-17, CC-19, and CC-21 to comply with the PaDEP discharge permit. Water 
samples were collected for screening only, and, therefore, no quality-assurance samples were collected, and data validation was not performed. The samples were analyzed by Wastex Industries, Inc., in Pottstown, Pa., by USEPA method 8260 using a gas chromatograph and mass spectrometer. Analytical data are given in appendix 6, table 1.

Water samples from on-site and off-site wells were collected for USEPA in 1995 and 1996 by private contractors. Water samples were collected during aquifer tests at approximately 1 hour, 12 hours, and 23 hours after the start of pumping by USGS for a USEPA contractor. Quality-assurance samples were collected, and the data were validated. Those data are given in appendix 6 , tables 2 and 3 .

\section{CONTINUOUS WATER-LeVEl MEASUREMENTS}

Water levels were measured continuously in wells CC-2, CC-9, and CC-13 on site and wells CH-2313 and CH-4394 off site from December 1994 or January 1995 to March to May 1996. Water levels were recorded with a strip chart or data logger. Wells were initially equipped with a strip chart recorder so that a continuous record of water-level fluctuations could be obtained. The chart drum was connected by a gear assembly to a float wheel. A float and counter weight assembly on a beaded cable in the well rose and fell with the water level. The changes were recorded as a continuous graph on the chart. After 1 to 2 months, the chart recorder was removed, and a shaft encoder was connected to the float assembly and a data logger. The data logger was programmed to record water levels hourly.

\section{REGIONAL HYDROGEOLOGIC SETTING}

The Malvern TCE Site is underlain by carbonate rocks. These rocks comprise an unconfined, fracturedrock aquifer that is recharged by precipitation and discharges locally to streams or to quarries that are being dewatered. Nomenclature used in this report is that of Lyttle and Epstein (1987). The nomenclature of the Pennsylvania Geological Survey has been used for previous reports on the ground-water resources of this area (Sloto, 1987; 1990; 1994).

\section{GeOLOGIC SETTING}

The rocks that underlie the Malvern TCE Site and vicinity are folded, faulted, and metamorphosed carbonate rocks of Cambrian and Ordovician age.
Basal quartzites and phyllite in the Chester Valley sedimentary sequence underlies the North Valley Hills to the north of Chester Valley (fig. 4).

The rocks that comprise the Chester Valley sedimentary sequence were deposited by continental margin sedimentation during the Upper Precambrian, Cambrian, and Ordovician. During that time, this area was the eastern edge of the North American continent (Rodgers, 1968, p. 141-148), and the continental basement was Precambrian felsic gneiss and other rocks that had been metamorphosed to amphibolite facies earlier during the Grenville orogeny (Crawford and Hoersch, 1984). Depositional environments for the Chickies Quartzite include intertidal sand flat, subtidal channel, and tidal flat pond (Goodwin and Anderson, 1974). Kauffman and Frey (1979) interpret the Antietam Formation as a line of barrier islands fronting the early Cambrian continent. Schwab (1970) interprets the Harpers Formation as a vertical repetition of nearshore and shallow marine platform sands and offshore, finegrained, deep-water turbidite deposits. The carbonate rocks were deposited in a shallow platform to deep marine environment.

The rocks that underlie the Malvern TCE Site and vicinity were deformed and metamorphosed to variable degrees. During the early Paleozoic, a tectonic collision at the eastern edge of the North American continent caused folding of continental shelf rocks and thrusting of oceanic sediments and magmatic arc rocks west over the Grenville basement and the clastic and carbonate rocks (Wagner and Srogi, 1987, p. 122). The Chester Valley sedimentary sequence rocks were metamorphosed to greenschist facies (Crawford and Crawford, 1980). The general structure of the carbonate rocks that underlie the center of the Valley Creek Basin and the noncarbonate rocks that underlie the North Valley Hills is a southdipping anticline. In places, the rocks dip very steeply. Small faults offset regional structures; nearly northsouth trending faults have been mapped as cutting across the Chester Valley near Mill Lane, south of the Malvern TCE Site (Bascom and Stose, 1938).

The formation underlying the disposal area is mapped as the Ledger Dolomite (Bascom and Stose, 1938). The Lower and Middle Cambrian Ledger Dolomite was deposited at the edge of a carbonate bank rimmed by a somewhat elevated limestone shoal tract (MacLachlan, 1994a, p. 20-21). The Ledger Dolomite is a white to light gray, massive to thickbedded, granular, relatively pure dolomite with a 


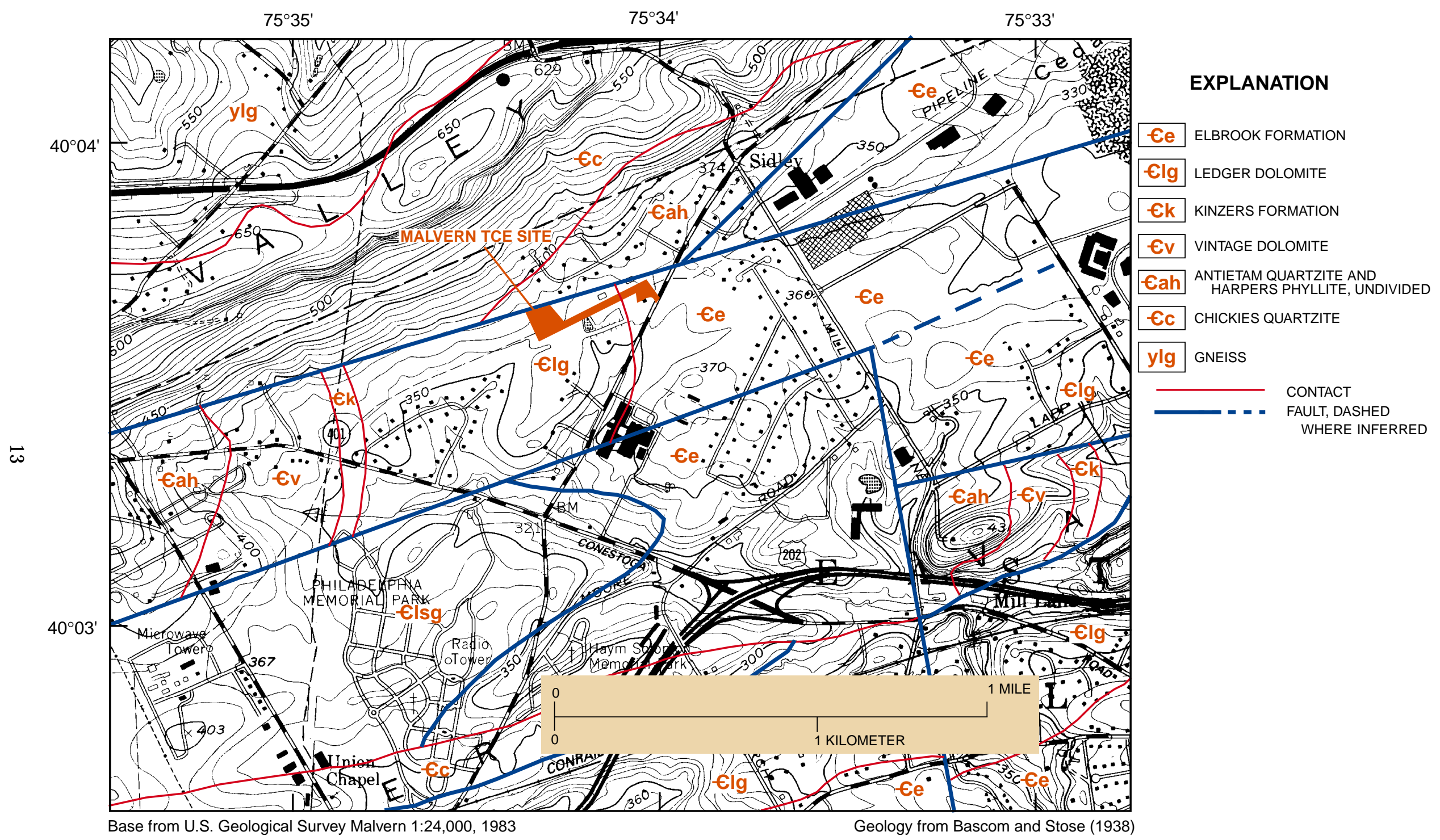

Figure 4. Geologic map of the Malvern TCE Site and vicinity, Chester County, Pennsylvania. 
high magnesium content. Beds often exceed $15 \mathrm{ft}$ in thickness and are without primary structure. The dolomite is interbedded with some siliceous beds and laminated limestones. The Ledger Dolomite contains a few beds of marble with a high calcium content. The Ledger Dolomite is 660 to 1,000 $\mathrm{ft}$ thick (Bascom and Stose, 1938).

The formation underlying the plant area is mapped as the Elbrook Formation (Bascom and Stose, 1938). The Middle Cambrian Elbrook Formation is a normal marine, predominately subtidal limestone deposited on a shelf that was receiving an input of mainly argillaceous terrigenous clastics (MacLachlan, 1994 a, p. 22). It is a light-gray to white, finely laminated, fine-grained, interbedded limestone and marble. Concentrations of coarse-grained mica on parting planes are a pressure-solution residue parallel to regional cleavage. The Elbrook Formation, which is 300 to $800 \mathrm{ft}$ thick, forms low hills in Chester Valley. The lower contact is gradational with the Ledger Dolomite. The unit mapped as the Elbrook Formation in Chester County may not be the same unit mapped as the Elbrook to the west of Chester County (R.T. Faill, Pennsylvania Geological Survey, written commun., 1991).

MacLachlan (1994a, p. 23) notes that the Lower (?) to Middle Cambrian Zooks Corner Formation is associated with the inner margin of the Ledger Dolomite bank margin facies and may represent the transition from bank margin to shelf. To the west of Chester County, the Zooks Corner Formation separates the Ledger Dolomite from the Elbrook Formation; it is less than $100 \mathrm{ft}$ thick and consists of dolomitic, silty, and sandy rock. MacLachlan (1994b, p. 152-153) indicates that the Zooks Corner Formation is present in the Downingtown area; however, this unit has not been mapped in Chester County.

The Chickies Quartzite and Antietam and Harpers Formations crop out north of the Malvern TCE Site and underlie the North Valley Hills. The Chickies Quartzite is a white to light-gray, thin- to thick-bedded, cross-bedded, medium-grained quartzite with interbeds of quartzose schist and sandy mica schist. The basal Hellam Member, which is not mapped as a separate unit in Chester County, is a coarse-grained, black-tourmaline-bearing quartzite and arkosic pebble conglomerate. The Chickies Quartzite is about $500 \mathrm{ft}$ thick and is a very resistant unit that forms prominent hills.
The Antietam and Harpers Formations are not mapped as separate units in Chester County. In general, they consist of gray, thin- to thick-bedded, laminated quartzite, quartzose schist, and sandy micaceous schist. The Antietam Formation is a gray, laminated quartzite and quartzose schist that grades downward into the Harpers. The Antietam is 150 to $450 \mathrm{ft}$ thick. The Harpers Formation is a gray, sandy, micaceous schist with interbeds of quartz schist and thin-bedded quartzite. It is 500 to $1,500 \mathrm{ft}$ thick.

The weathered zone of the dolomite underlying the site ranges from 18 to $86 \mathrm{ft}$ thick on the basis of interpretation of natural-gamma logs. The weathered zone consists of clay, sand, and sandy clay. Quartzite fragments derived from quartzites to the north of the site are mixed with clay in the upper part of the weathered zone, and dolomite fragments derived from the underlying bedrock are mixed with the clay in the lower part of the weathered zone. Descriptions of the weathered-zone materials are given in $\mathrm{CH} 2 \mathrm{M}$ HILL, Inc. (1997).

\section{Hydrologic SETTING}

The bedrock aquifer in Chester Valley generally is under unconfined (water-table) conditions and is recharged by local precipitation. Ground water also enters the aquifer by inflow from the topographically higher crystalline-rock uplands to the north and south of the valley. The average annual recharge (1983-87) to the Valley Creek Basin is 21 in/yr (Sloto, 1994, p. 41).

Ground water in the bedrock aquifer of Chester Valley flows through a network of interconnected secondary openings that include joints, faults, bedding planes, and fractures. The number and size of the water-bearing openings determine the secondary porosity of the rock; the number, size, and degree of interconnection of the openings determine the secondary permeability. Primary porosity in the carbonate rocks of Chester Valley is insignificant. In carbonate rocks, the secondary openings commonly are enlarged by solution. Permeability of carbonate rock is predominately the result of solution-enlarged fractures. Some fractures enlarged by solution are several feet wide; however, most are only a fraction of an inch wide, but large quantities of water can move through these fractures. Where solution has been active, permeability may be high; elsewhere, the same unit may be nearly impermeable. 
The primary weathering process in carbonate rock is dissolution of calcite and dolomite. Mineral dissolution is most active above and within the zone of water-table fluctuation where water movement is relatively rapid, and recharge water is acidic. Clay and unconsolidated material sometimes move downward from the surface, filling fractures. This results in decreased well yields and turbid groundwater discharge from some wells. Dissolution of carbonate rock also is active at and near the contact between carbonate and crystalline rock. Acidic ground water flows from the topographically higher North Valley Hills underlain by crystalline rock to the topographically lower Chester Valley underlain by carbonate rock. The median $\mathrm{pH}$ of ground water in quartzite in Chester County is 5.1 (Sloto, 1994, p. 58).

The depth of weathering in carbonate rocks is highly variable. Deeply weathered zones can be found adjacent to outcrops. Weathering along bedding planes and fractures in dipping strata is common in the carbonate rock of Chester Valley. As weathering moves downward at a steep angle in the formation, solid rock is left between the weathered areas.

Some of the aquifer characteristics that can be used to describe ground-water flow and assess the productivity of an aquifer under unconfined conditions are transmissivity, specific capacity, and well yield. Transmissivity is the rate at which a fluid is transmitted through a unit width of the aquifer under a unit hydraulic gradient; transmissivity is equal to the hydraulic conductivity multiplied by the saturated thickness of an aquifer (Lohman, 1972). Units of transmissivity are length squared per time, such as feet squared per day. Transmissivity partly determines the potential for contaminant transport in an aquifer because the ability of water and contaminants to move through an aquifer is controlled by the permeability of aquifer materials and ground-water velocity, as well as by aquifer dispersivity and chemical properties.

Specific capacity is a better measure of aquifer productivity than well yield because it can be related directly to aquifer transmissivity. Specific capacity is calculated by dividing the pumping rate of a well by the drawdown, and it reflects the combined efficiency of the well and aquifer transmissivity. Specific capacity for a well pumped at a constant yield decreases with time. Specific capacity is determined from aquifer tests. Specific capacity, together with available drawdown, provides a reasonable basis for estimating well yield.

Wells drilled in the Ledger Dolomite yield more water than wells drilled in the Elbrook Formation. The median yield of domestic wells drilled in the Ledger Dolomite is $35 \mathrm{gal} / \mathrm{min}$; the median yield of domestic wells drilled in the Elbrook Formation is $15 \mathrm{gal} / \mathrm{min}$. The median yield of nondomestic wells drilled in the Ledger Dolomite is $275 \mathrm{gal} / \mathrm{min}$; the median yield of nondomestic wells drilled in the Elbrook Formation is $75 \mathrm{gal} / \mathrm{min}$ (Sloto, 1994, p. 23).

\section{WATER LEVELS}

Water levels measured in wells in an unconfined aquifer indicate the level of the water table. Water levels commonly are measured as the depth to water from land surface and are expressed as depth to water below land surface or altitude of the water level above sea level. Water levels rise in response to recharge to the ground-water system from precipitation and decline in response to discharge from the ground-water system to pumping wells and quarries, to the atmosphere by groundwater evapotranspiration, and to streams. Water levels generally rise during the late fall, winter, and early spring when ground-water and soil-moisture evapotranspiration are at a minimum and recharge is at a maximum. Water levels generally decline during the late spring, summer, and early fall when groundwater and soil-moisture evapotranspiration are at a maximum and recharge is at a minimum.

Water levels respond quickly to precipitation. The hydrograph of well CC-2 during October 1995 shows a rise in water level during or immediately following precipitation (fig. 5). The quantity of precipitation that causes recharge and the quantity of recharge from precipitation depend on antecedent soil-moisture conditions and the rate and duration of precipitation.

Water levels were measured continuously in three wells on site and two wells off site and monthly in all wells on site. Off-site well CH-2313 (location on fig. 1) has been measured monthly by USGS since April 1978. The hydrograph of well $\mathrm{CH}-2313$ for 1978-96 shows that water levels measured during this study cover a range from below average to above average (fig. 6). 


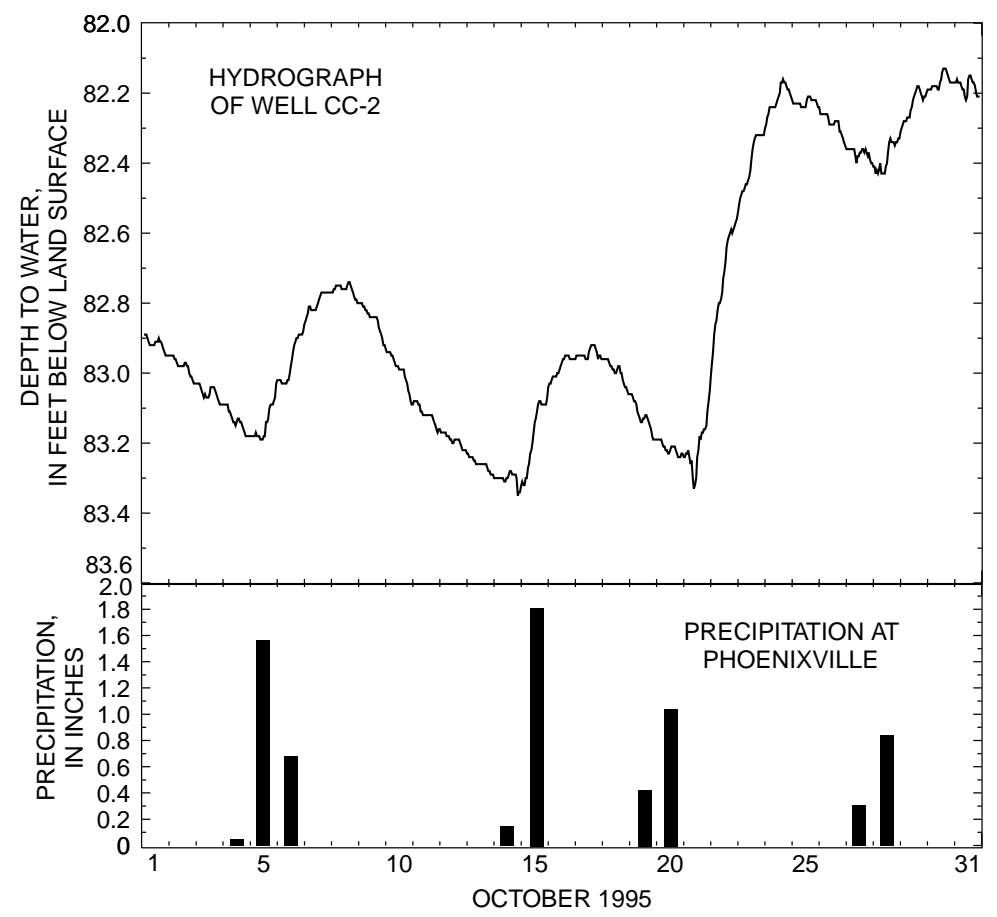

Figure 5. Hydrograph from well CC-2, October 1995, Malvern TCE Site, and precipitation at Phoenixville, Chester County, Pennsylvania.

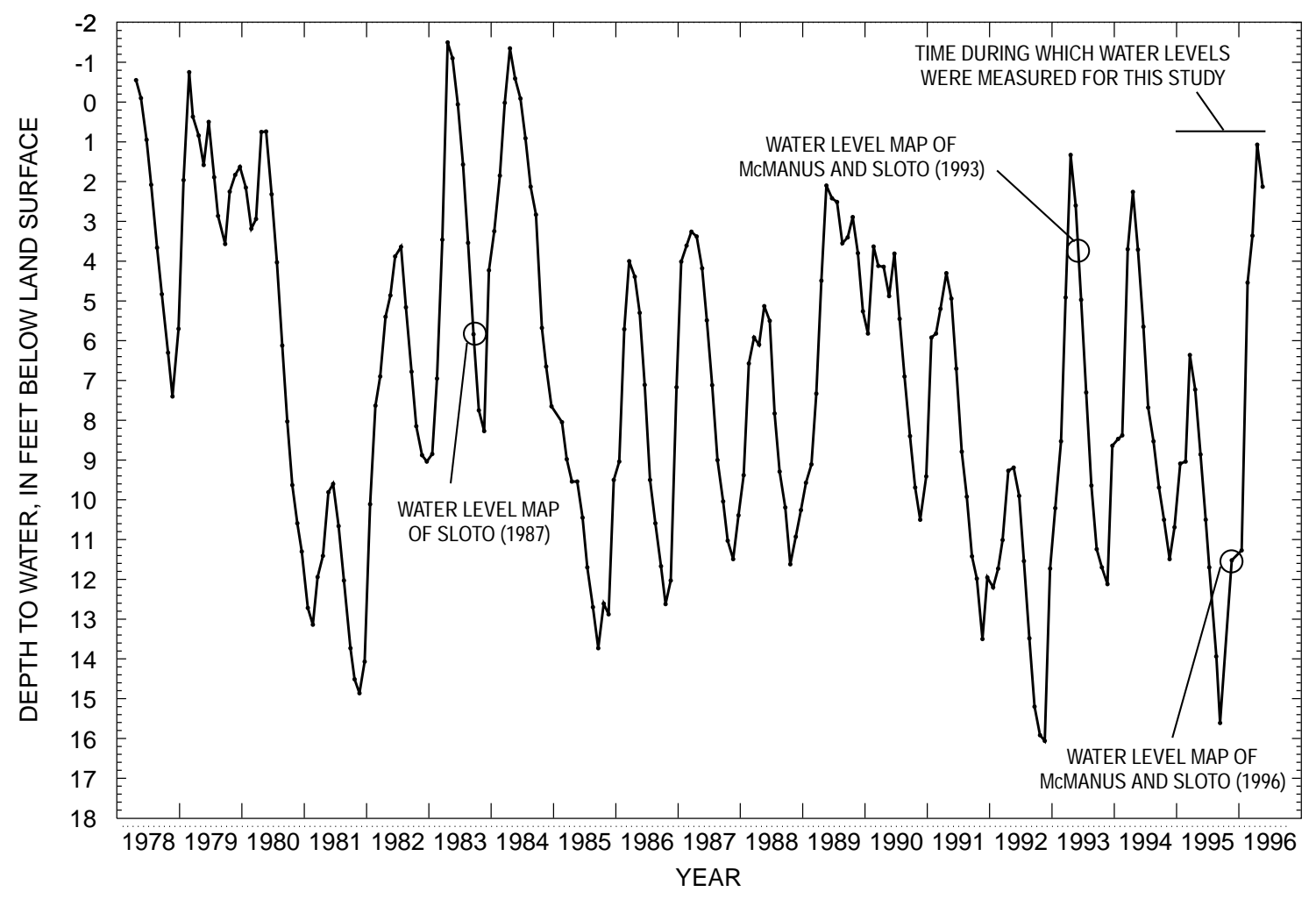

Figure 6. Hydrograph from well CH-2313, April 21, 1978, to May 20, 1996, East Whiteland Township, Chester County, Pennsylvania. 
The hydrograph of off-site well CH-2313 (fig. 7) shows a response to precipitation and seasonal variation. The hydrograph of off-site well $\mathrm{CH}-4394$ (fig. 8) shows a similar seasonal variation and a similar response to precipitation during September 1995 to January 1996. However, the recovery of the water level in well CH-4394 from January to March 1996 is a steady recovery that shows little response to precipitation.

\section{Direction OF GROUND-WATER Flow}

Because ground water flows from higher to lower head, the general direction of ground-water flow can be determined from a map of the water-table surface. Water levels are lower (depth to water greater) in areas of ground-water withdrawal. Ground-water withdrawal for dewatering the Catanach quarry has caused a cone of depression in the water-table surface that reaches to the plant area (pl. 1). The pumping rate of the Catanach quarry was estimated at $5.2 \mathrm{Mgal} / \mathrm{d}$ on May 1, 1995, by measuring the inflow to the quarry sump with a current meter.

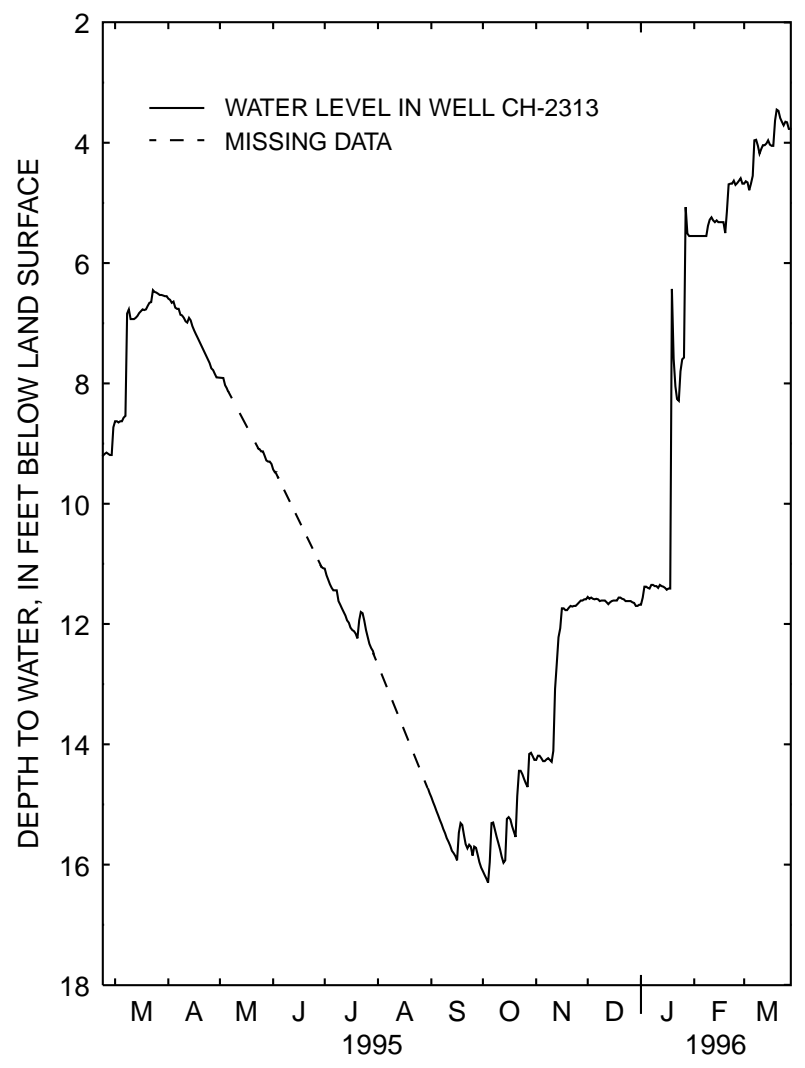

Figure 7. Hydrograph from well $\mathrm{CH}-2313$, February 22, 1995, to March 28, 1996, East Whiteland Township, Chester County, Pennsylvania.
The water-table map of McManus and Sloto (1996) is included in this report as plate 1. Generalized ground-water-flow directions from the water-table map (pl. 1) are shown on figure 9. Ground-water-flow paths are estimated based on available water-level data. A ground-water divide is located between the plant area and the disposal area (fig. 9). From the plant area, ground water flows northeast to the Catanach quarry, the discharge point, along the hydraulic gradient caused by quarry dewatering. In the vicinity of the plant, the direction of ground-water flow is to the northeast with a gradient of approximately 0.014 . Near the Catanach quarry, the gradient is approximately 0.023 . The regional gradient between the plant area and the quarry is 0.019 .

From the disposal area, ground water flows south-southwest toward Valley Creek (fig. 9). Streamdischarge measurements made by Sloto (1987, p. 9596) indicate that Valley Creek above Hillbrook Circle is a losing reach (the stream loses water to the groundwater system) and Valley Creek below Hillbrook Circle is a gaining reach (ground water discharges to the stream). The generalized ground-water-flow path is shown on figure 9 . Some uncertainty exists in the

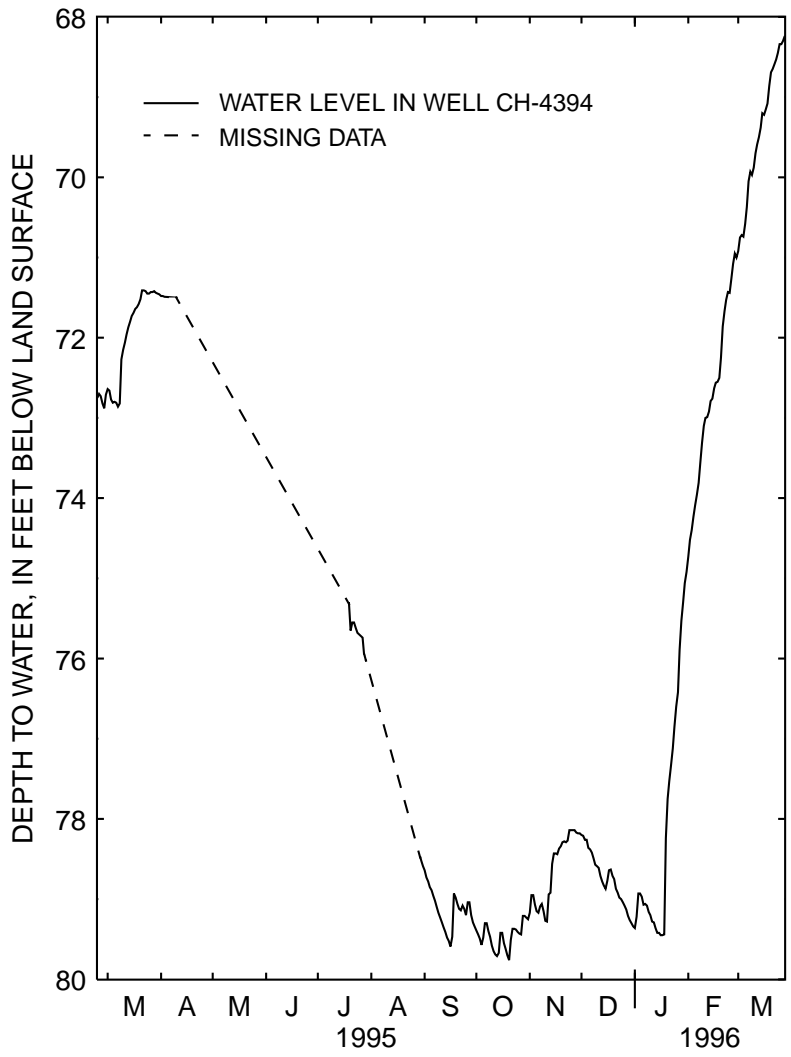

Figure 8. Hydrograph from well CH-4394, February 23, 1995, to March 28, 1996, East Whiteland Township, Chester County, Pennsylvania. 


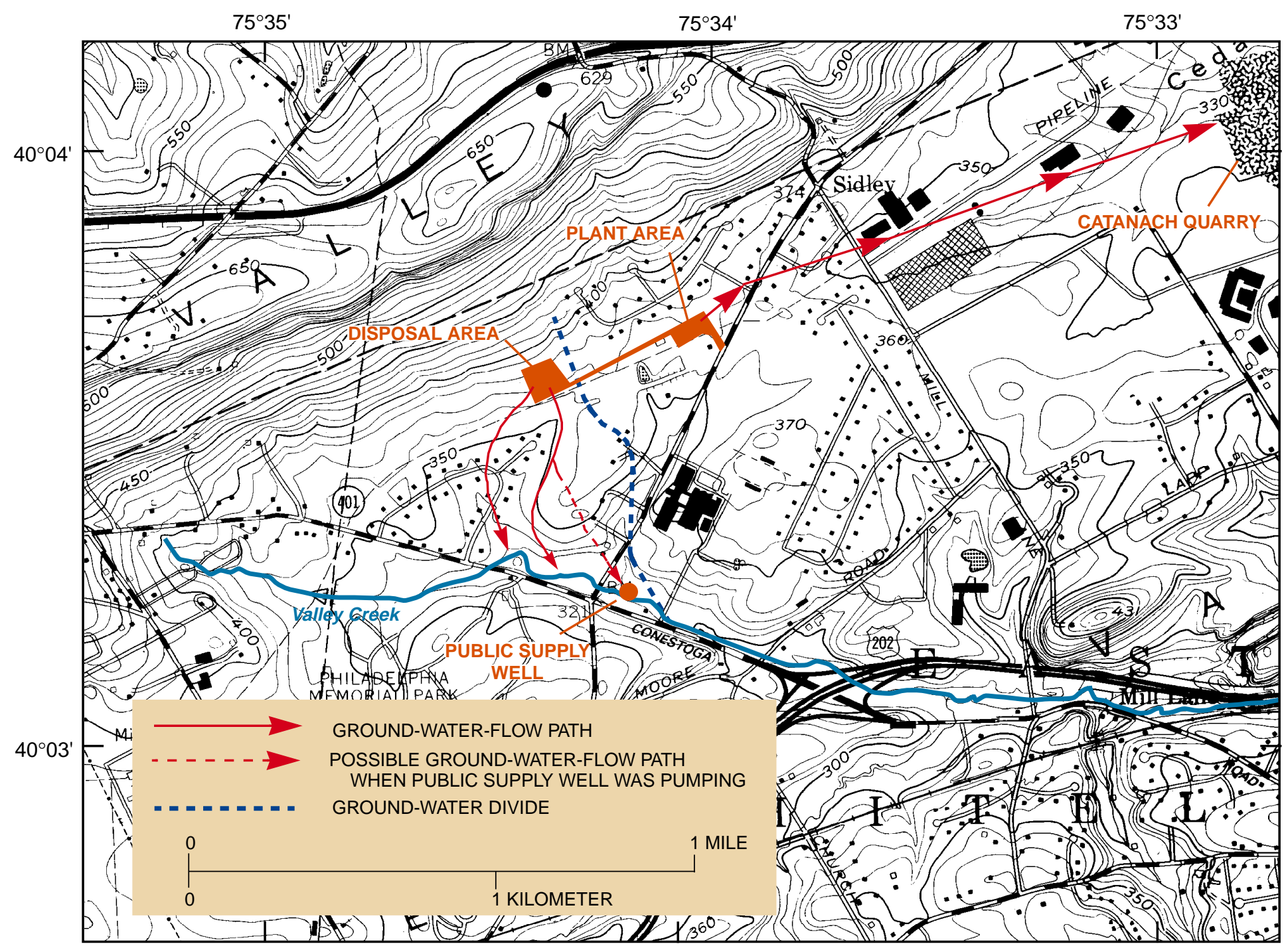

Base from U.S. Geological Survey Malvern 1:24,000, 1983

Figure 9. Generalized ground-water-flow directions in the vicinity of the Malvern TCE Site, Chester County, Pennsylvania. 
interpretation of the exact ground-water-flow path because no data are available for the area north of Hillbrook Circle. The dashed line on figure 9 shows a potential flow path when public supply well $\mathrm{CH}-2199$ was pumping; this is based on the water-table map of Sloto (1987, pl. 1). Well CH-2199 stopped pumping on November 30, 1992.

The hydraulic gradient between the disposal area and Valley Creek is 0.001, which is less than onetenth of the hydraulic gradient at the plant area. The hydraulic gradient can indicate relative permeabilities of unconfined aquifers. Under identical flow conditions, the change in head over distance is less in aquifers with high permeability than in aquifers with low permeability. The water-table maps of Sloto (1987) and McManus and Sloto (1993; 1996) show that the hydraulic gradient is less steep (water-table contours are less closely spaced) in the vicinity of the disposal area and Hillbrook Circle than in other parts of the mapped area, which indicates that the transmissivity of the aquifer in this vicinity is higher than in other parts of the mapped area. This is confirmed by the aquifer tests.

Water-table maps were prepared by Sloto (1987, pl. 1) for October 1983 during a time of about average water levels, by McManus and Sloto (1994) for May and June 1993 during a time of relatively high water levels, and by McManus and Sloto (1996) for December 1994 (pl. 1) during a time of relatively low water levels (fig. 6). A comparison of these maps shows that the general shape of the water table has remained the same through time and for different climatic conditions. The hydraulic gradient between the plant area and Catanach quarry was nearly the same; it varied from 0.017 in 1983 to 0.021 in 1993. Lack of sufficient detail in the disposal area and Hillbrook Circle in the maps of Sloto (1987) and McManus and Sloto (1993) prevents a comparison of gradients with the map of McManus and Sloto (1996). All three maps show ground-water flow from the disposal area toward Valley Creek.

\section{HYDROGEOLOGY AND CONTAMINANT DISTRIBUTION}

\section{Plant ARea}

At the plant area, five wells (CC-2, CC-3, CC-6, CC-7, and CC-13) were drilled for previous investigations (fig. 10). Construction data for these wells are summarized in table 1 . Drilling logs and well-construction diagrams are compiled by $\mathrm{CH} 2 \mathrm{M}$ HILL, Inc. (1995). Five wells (CC-19, CC-20, CC-21, CC-22, and CC-23) were drilled for this investigation (fig. 10). Geologic logs are given in appendix 2, and well-construction diagrams are given in appendix 3 .

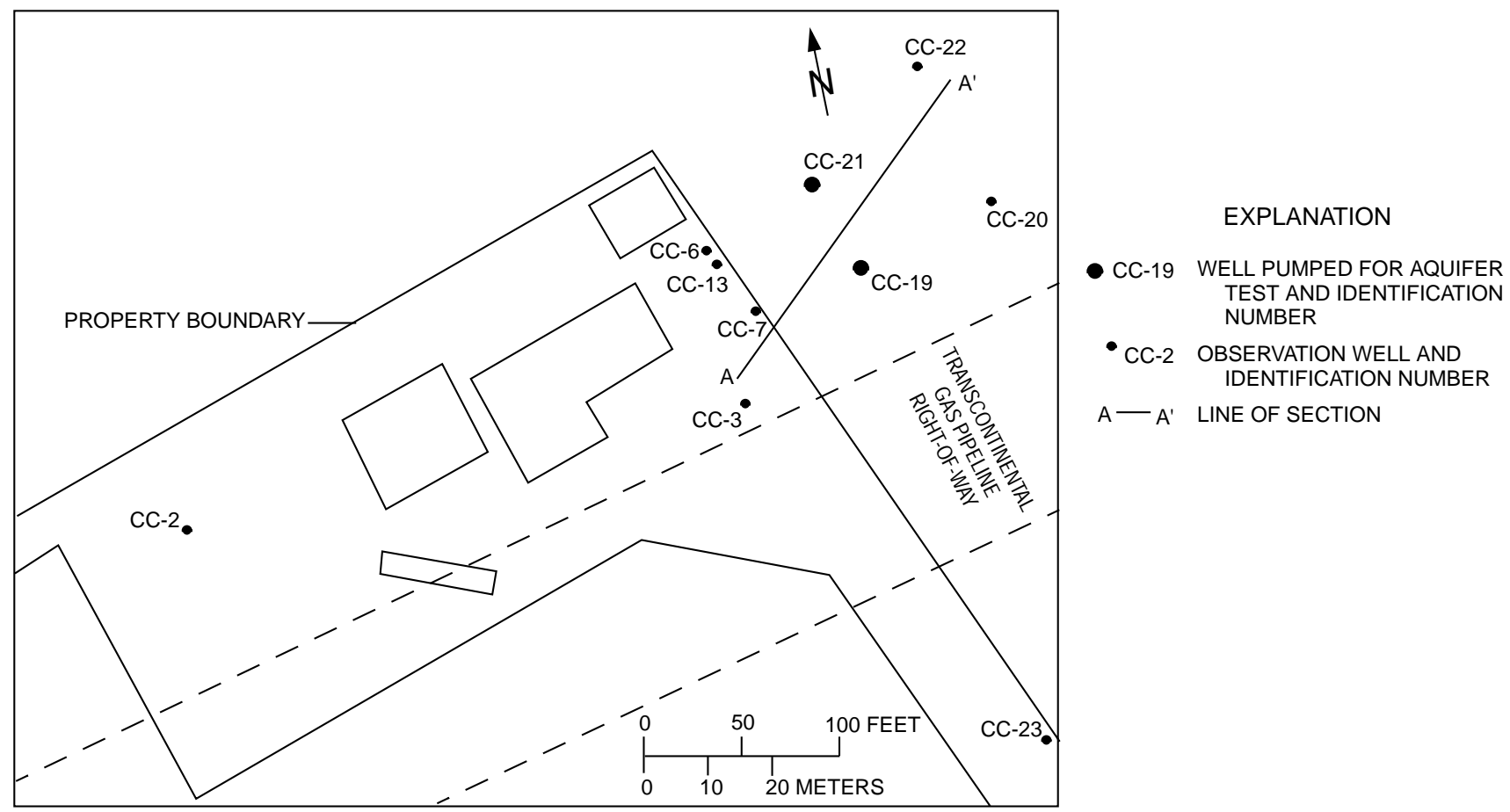

Figure 10. Location of wells at the plant area, Malvern TCE Site, Chester County, Pennsylvania. 


\section{RESULTS OF BOREHOLE GEOPHYSICAL LOGGING}

Borehole geophysical logs and borehole television surveys were run in wells CC-2, CC-7, CC-13, CC-19, CC-20, and CC-22. Only a naturalgamma log was run in well CC-21 because it was collapsing and was completed as a monitor well before logging. Borehole geophysical logs were not run in screened wells CC-3 and CC-6. A caliper log only was run in well CC-7 because of the short open interval.

\section{CC-2}

Well CC-2, originally drilled to a depth of $110 \mathrm{ft}$ below land surface (bls), had collapsed to $103 \mathrm{ft}$ bls at the time of logging. The caliper log (fig. 11) shows that the total depth of the well is $103 \mathrm{ft}$ and that it is cased with 6-in.-diameter casing to $63 \mathrm{ft}$ bls. The caliper $\log$ shows major fractures or solution openings at 63-66.5, 74-81, 90-91, and 99-103 ft bls. These openings contribute material filling the well. Images made from the borehole television survey are shown in figures $12 \mathrm{~A}-\mathrm{C}$. The fracture or solution opening at $65.2 \mathrm{ft}$ bls is shown in figure $12 \mathrm{~A}$, the fracture or solution opening at $77.3 \mathrm{ft}$ bls is shown in figure $12 \mathrm{~B}$, and the fracture or solution opening at $100.4 \mathrm{ft}$ bls is shown in figure $12 \mathrm{C}$. The natural-gamma log shows an elevated response from near land surface to $64 \mathrm{ft}$ bls, which indicates the thickness of the weathered (clay) zone overlying bedrock. The fluid-resistivity and fluidtemperature logs do not indicate vertical borehole flow.

\section{CC-7}

Well CC-7 was originally drilled to a depth of $120 \mathrm{ft}$ bls but has collapsed. Only a caliper log was run because of the short length $(25 \mathrm{ft})$ of open hole. The caliper $\log$ (fig. 13) shows that the total depth of the borehole is $107 \mathrm{ft}$ and that it is cased with 6-in.-diameter casing to $82 \mathrm{ft}$ bls. The caliper log shows major fractures or solution openings at 81-82.5 and $82.5-89 \mathrm{ft}$ bls. The drilling log indicates that the fracture at $84 \mathrm{ft}$ bls yielded about $1 \mathrm{gal} / \mathrm{min}$ of water; it is the only water-bearing fracture penetrated by the well (fig. 14).

\section{CC-13}

Well CC-13 was originally drilled to a depth of $180 \mathrm{ft}$ bls. The drilling log indicates that a fracture yielding $6 \mathrm{gal} / \mathrm{min}$ of water was encountered at $135 \mathrm{ft}$ bls. The caliper log (fig. 15) shows that the total depth of the borehole is $178 \mathrm{ft}$ and that it is cased with 6-in.-diameter casing to $123 \mathrm{ft}$ bls. The caliper log shows a decrease in borehole diameter at $128 \mathrm{ft}$ bls where the drill bit size was changed. Neither the caliper log or the borehole television survey showed any significant fractures penetrated by the well. The natural-gamma log shows an elevated response from near land surface to $52 \mathrm{ft}$ bls, which indicates the thickness of the weathered (clay) zone overlying bedrock. The fluid-resistivity and fluid-temperature logs do not indicate vertical borehole flow.

\section{CC-19}

Well CC-19 was originally drilled to a depth of $303 \mathrm{ft}$ bls. Two water-bearing fractures were penetrated; the fracture at $145 \mathrm{ft}$ bls produced $5 \mathrm{gal} / \mathrm{min}$ of water, and the fracture at $166 \mathrm{ft}$ bls produced $20 \mathrm{gal} / \mathrm{min}$ of water. The caliper log (fig. 16) shows these two fractures plus two nonwaterproducing fractures at 104 and $262 \mathrm{ft}$ bls. Images made from the borehole television survey are shown in figures $17 \mathrm{~A}$ and $17 \mathrm{~B}$. The water-bearing fracture at $146 \mathrm{ft}$ bls is shown in figure 17A, and the waterbearing fracture at $166 \mathrm{ft}$ bls is shown in figure 17B. The natural-gamma log shows an elevated response from near land surface to $62 \mathrm{ft}$ bls, which indicates the thickness of the weathered (clay) zone overlying bedrock. The fluid-resistivity log shows major breaks in slope at about 146 and $168 \mathrm{ft}$ bls and little gradient between these points, indicating a zone of borehole flow. The fluid-temperature log shows a break in slope at about $146 \mathrm{ft}$ bls. Measurements of borehole flow, made using a heat-pulse flowmeter, at 152 and $173 \mathrm{ft}$ bls showed upward flow of 0.2 and $0.09 \mathrm{gal} / \mathrm{min}$, respectively. Water enters the well through fractures at $177 \mathrm{ft}(0.09 \mathrm{gal} / \mathrm{min})$ and $166 \mathrm{ft}$ bls $(0.12 \mathrm{gal} / \mathrm{min})$, flows upwards at $0.2 \mathrm{gal} / \mathrm{min}$, and exits the well through the fracture at $145 \mathrm{ft}$ bls.

\section{CC-20}

Well CC-20 was originally drilled to $303 \mathrm{ft}$ bls. Only one water-bearing fracture, which produced $5 \mathrm{gal} / \mathrm{min}$ at $250 \mathrm{ft}$ bls, was penetrated (fig. 18). An image made from the borehole television survey shows the water-bearing fracture at $250 \mathrm{ft}$ bls (fig. 19). The natural-gamma log shows an elevated response from near land surface to $18 \mathrm{ft}$ bls, which is where solid rock was encountered during drilling. The elevated gamma response from 75 to $79 \mathrm{ft}$ bls represents a mud-filled fracture or solution channel, which is at the approximate altitude of the water table. This zone was cased off. The fluid-resistivity and fluid-temperature logs do not indicate vertical borehole flow. 


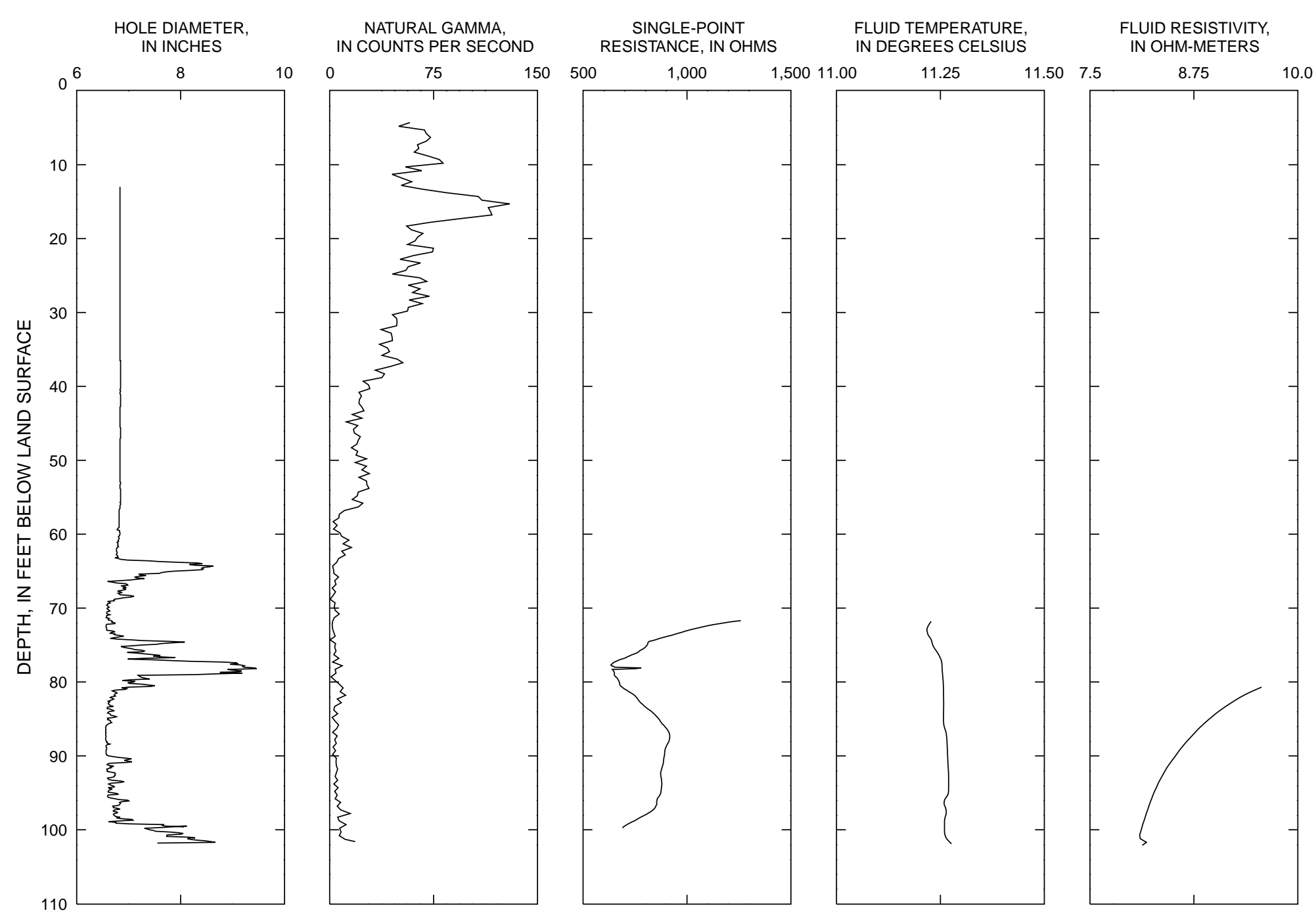

Figure 11. Borehole geophysical logs for well CC-2, Malvern TCE Site, Chester County, Pennsylvania. 


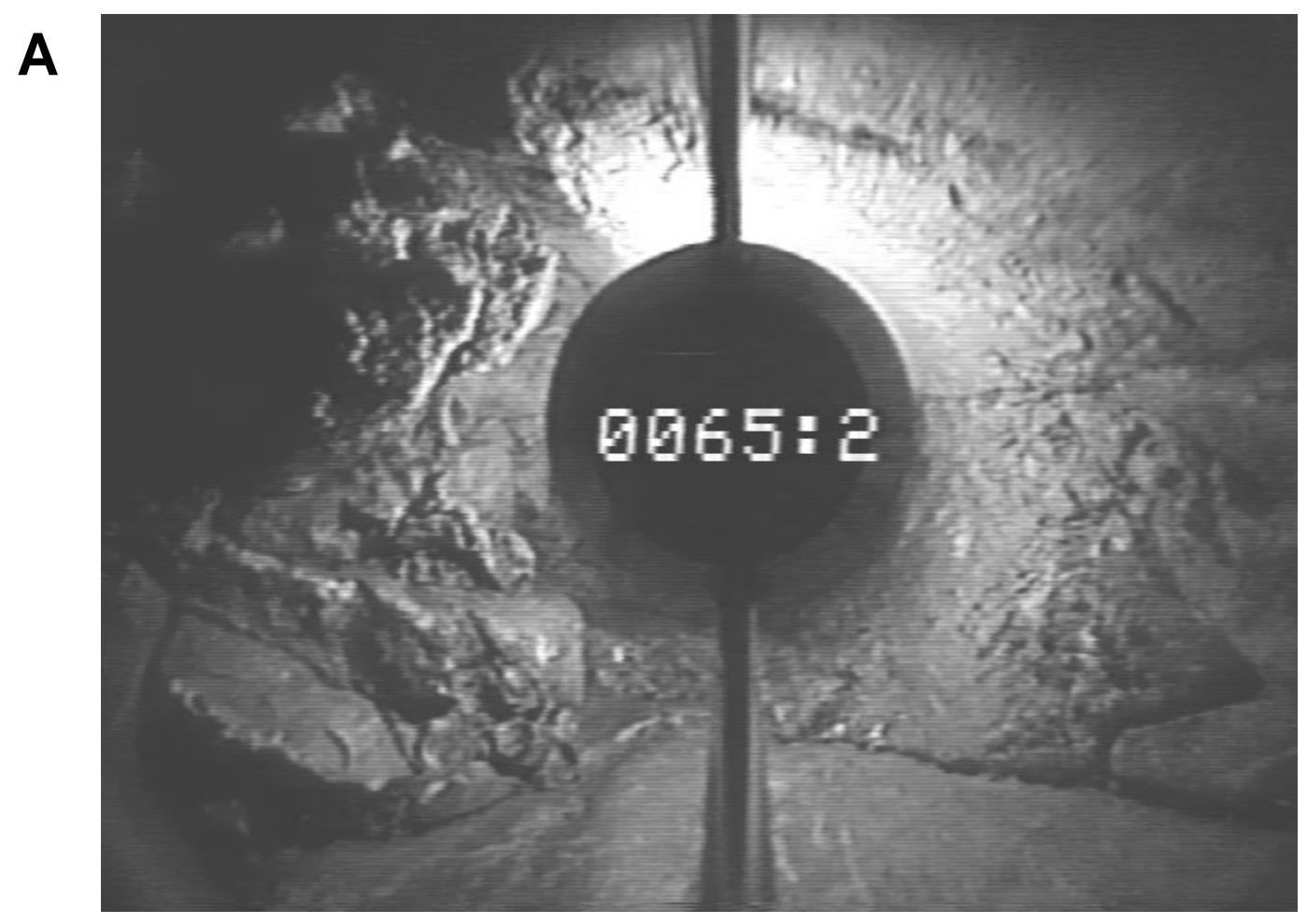

B

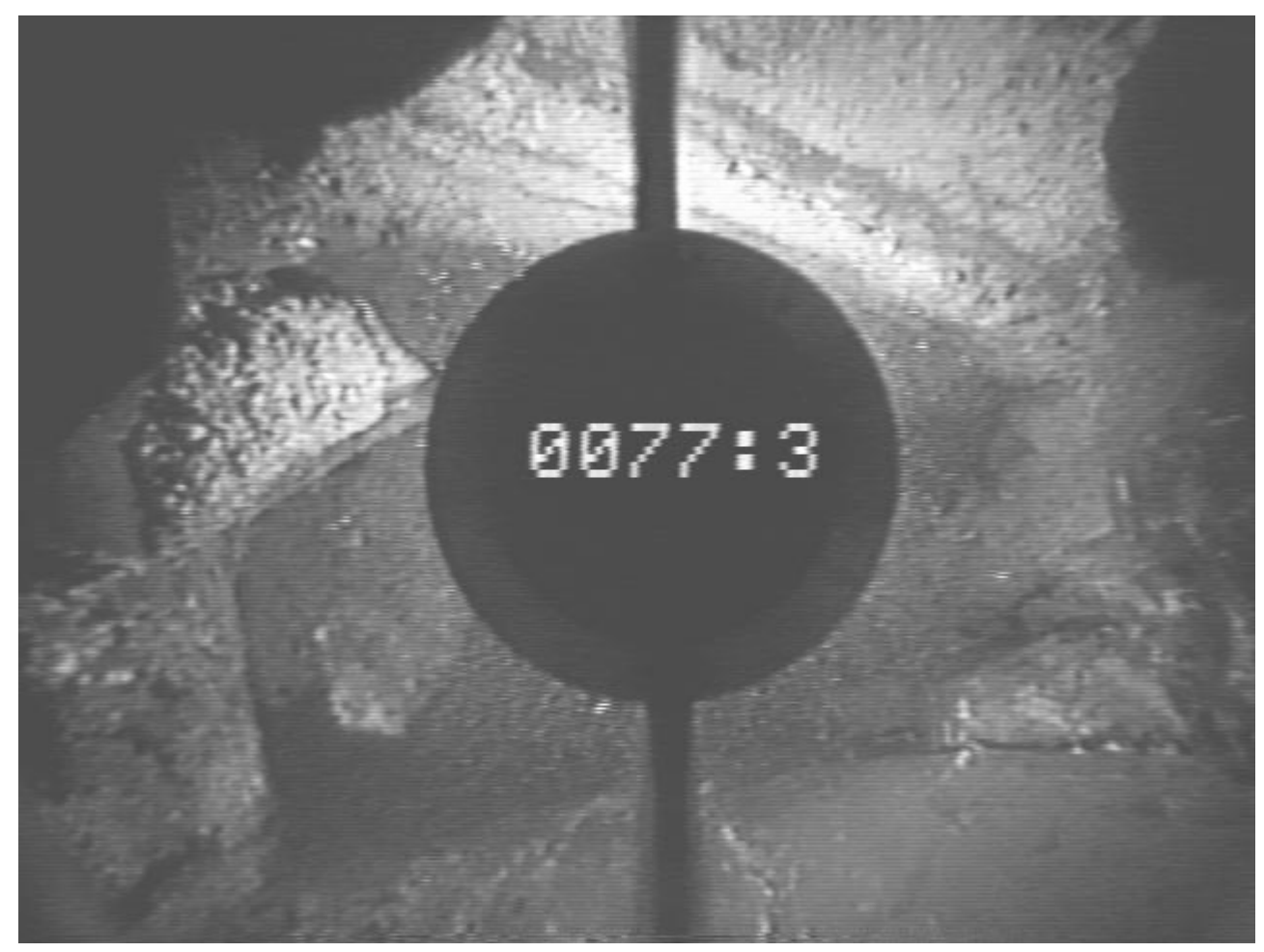

Figure 12. Images from borehole television survey showing fractures in well CC-2, Malvern TCE Site, Chester County, Pennsylvania. (A) 65.2 feet below land surface. (B) 77.3 feet below land surface. (C) 100.4 feet below land surface. 


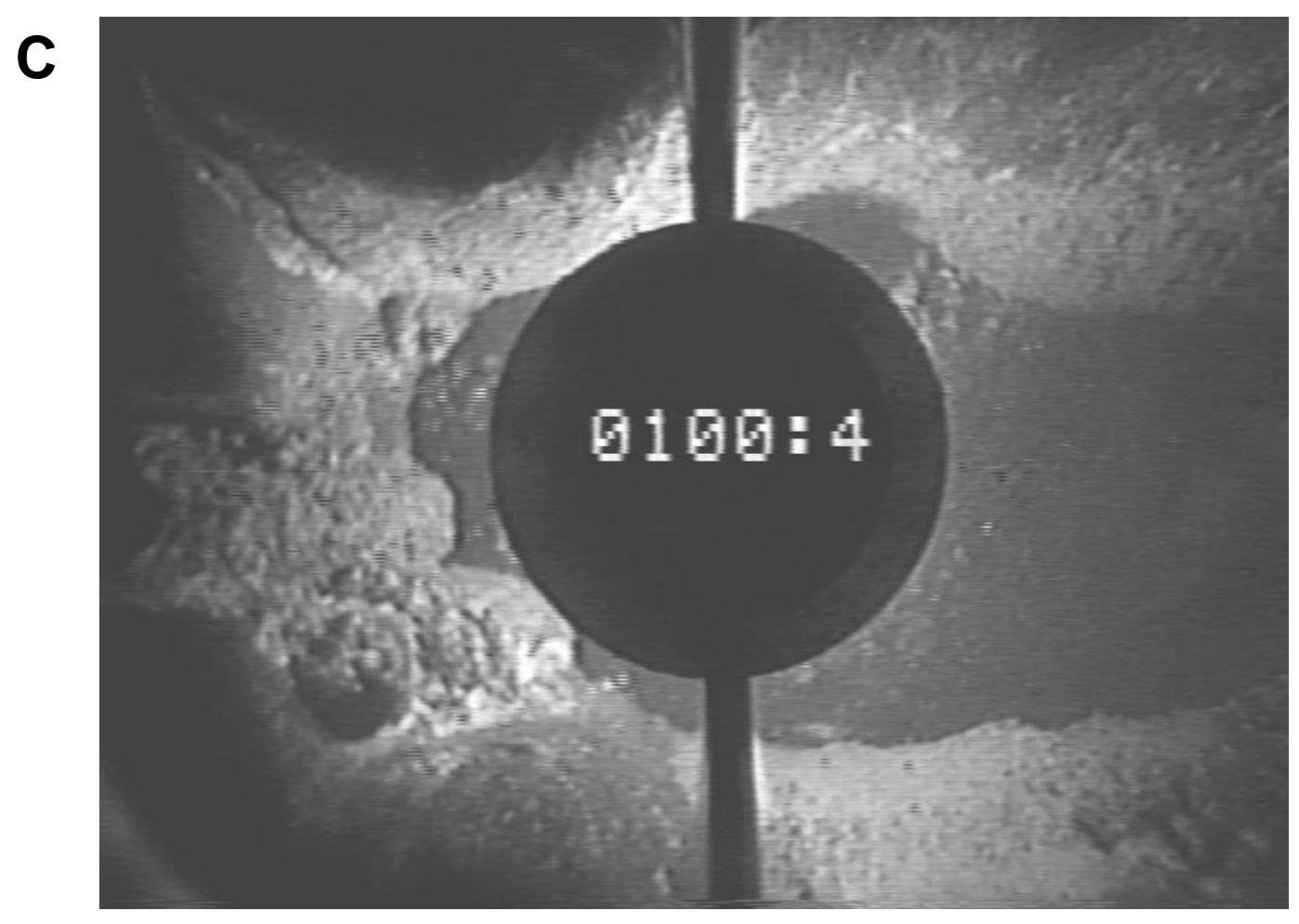

Figure 12. Images from borehole television survey showing fractures in well CC-2, Malvern TCE Site, Chester County, Pennsylvania. (A) 65.2 feet below land surface. (B) 77.3 feet below land surface.

(C) 100.4 feet below land surface-Continued. 


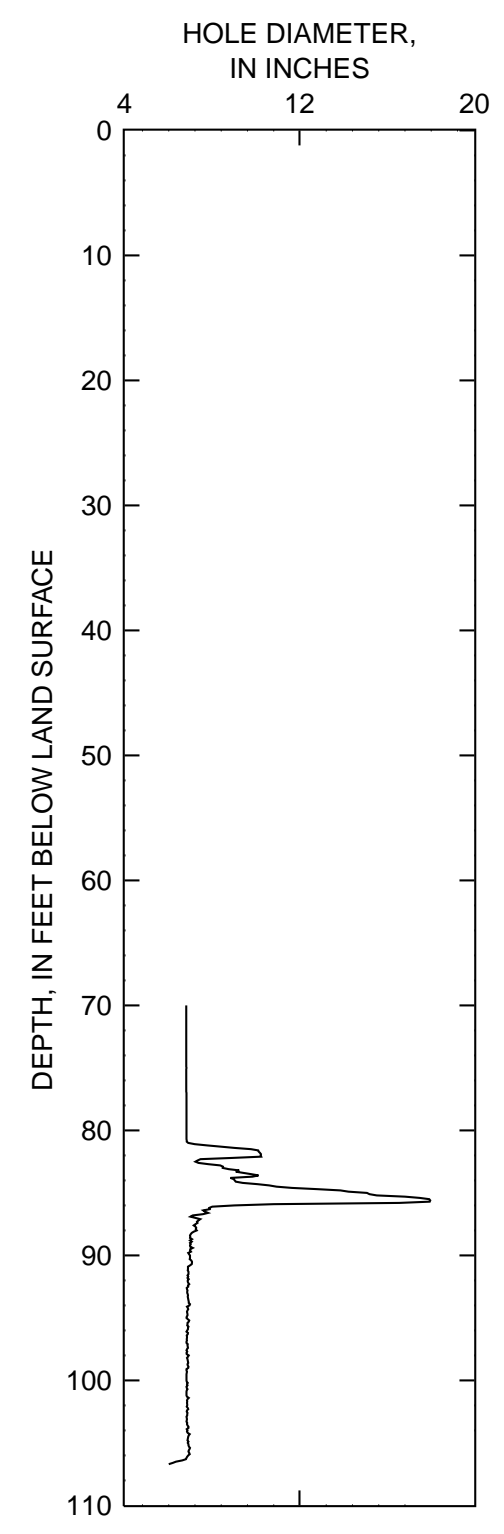

Figure 13. Caliper log for well CC-7, Malvern TCE Site, Chester County, Pennsylvania.

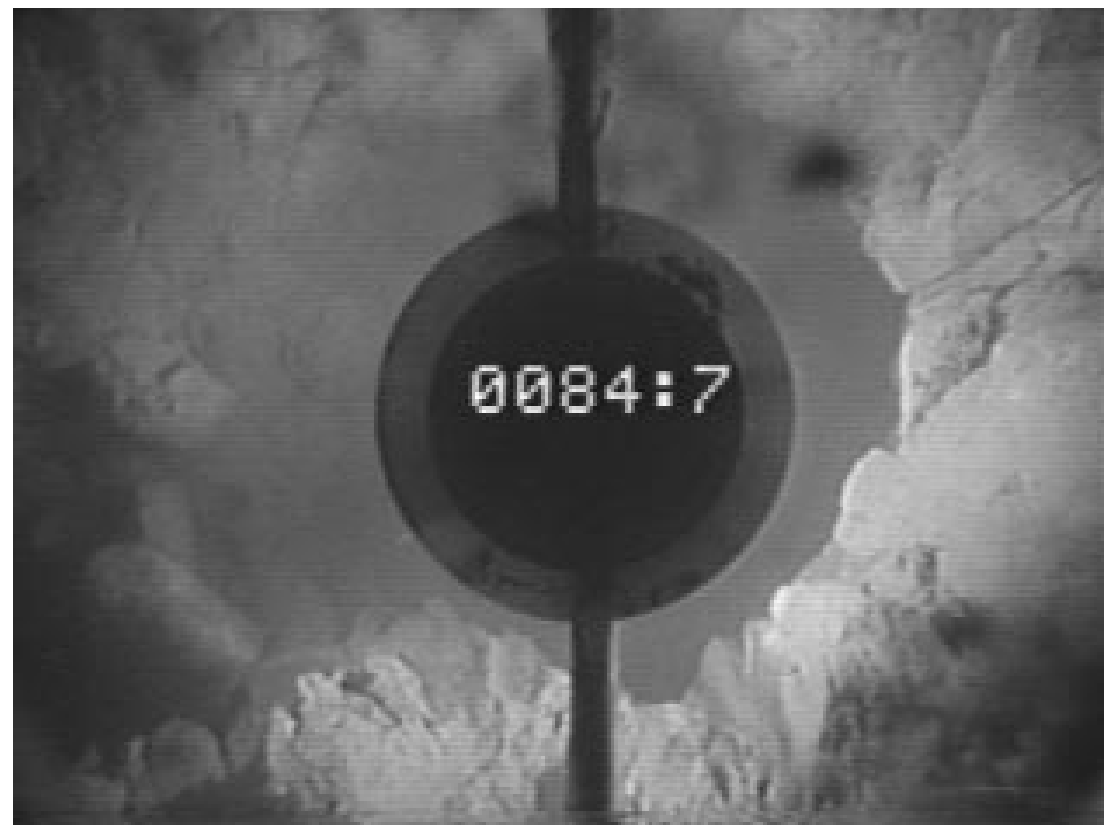

Figure 14. Image from borehole television survey showing fracture at 84.7 feet below land surface in well CC-7, Malvern TCE Site, Chester County, Pennsylvania. 

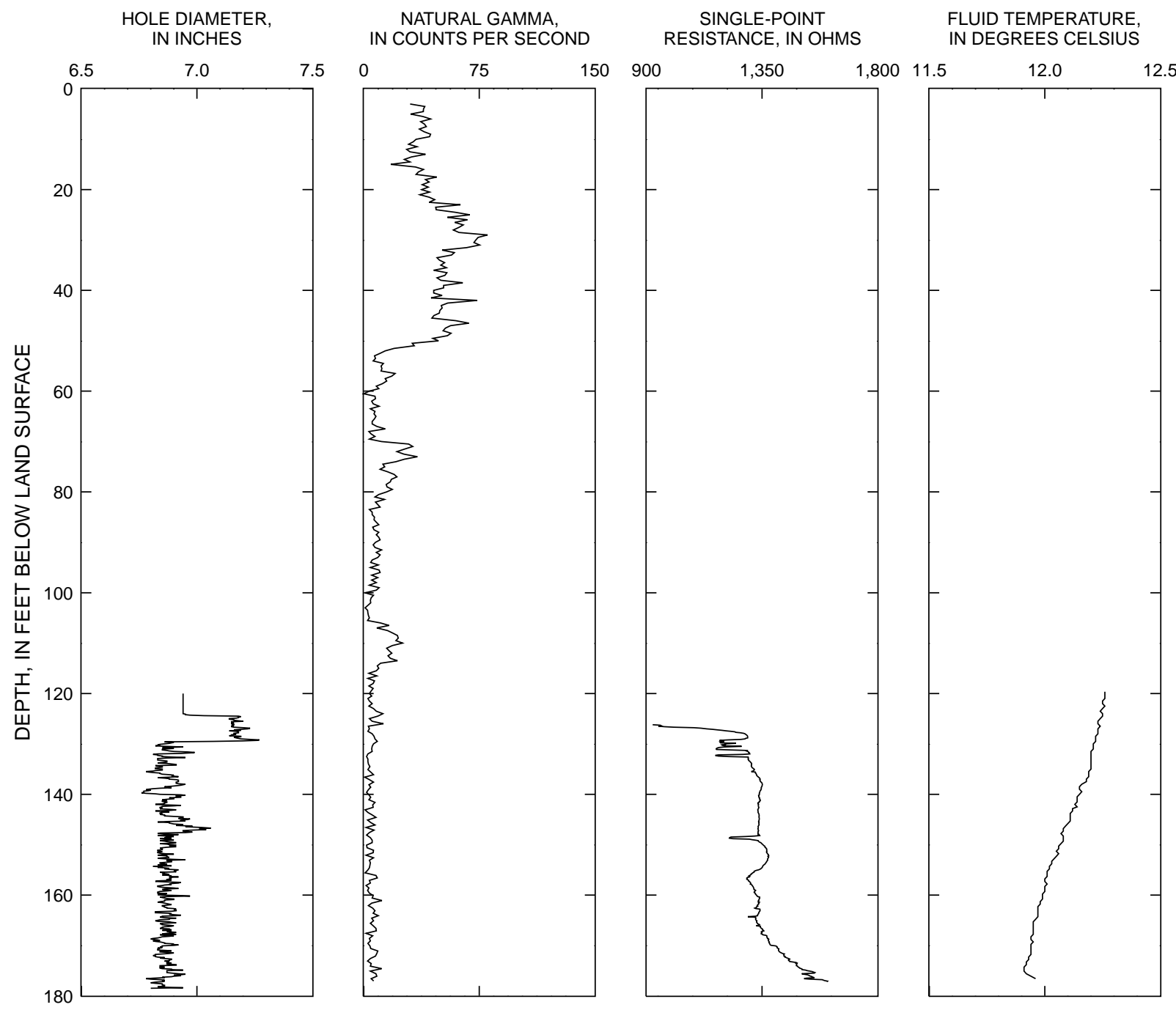

FLUID RESISTIVITY,

IN OHMMETERS

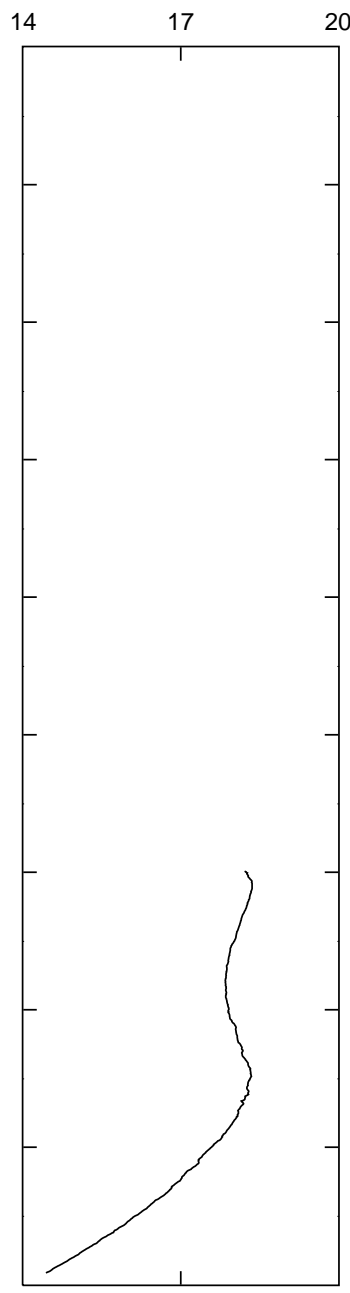

Figure 15. Borehole geophysical logs for well CC-13, Malvern TCE Site, Chester County, Pennsylvania. 


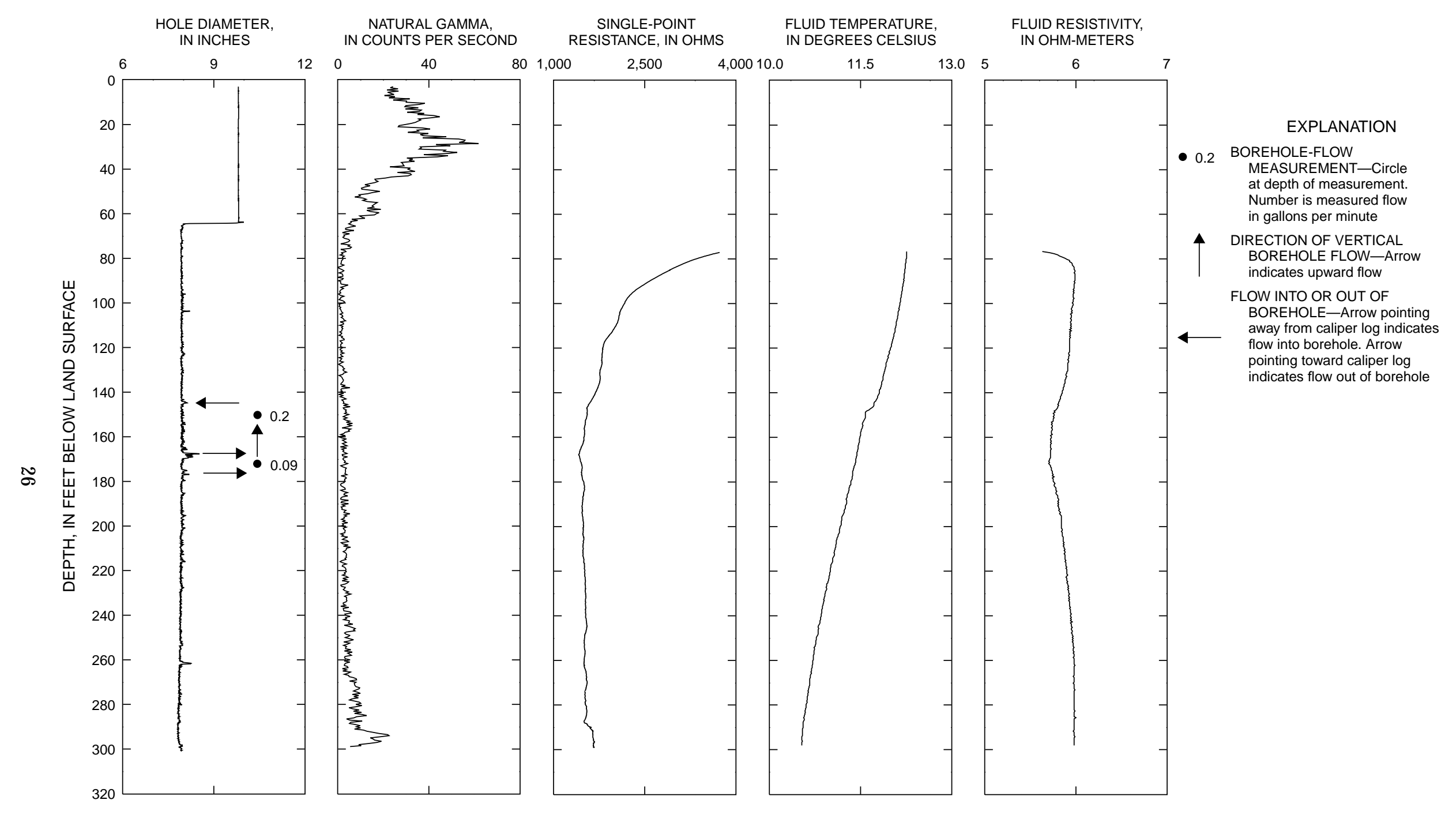

Figure 16. Borehole geophysical logs for well CC-19, Malvern TCE Site, Chester County, Pennsylvania. 

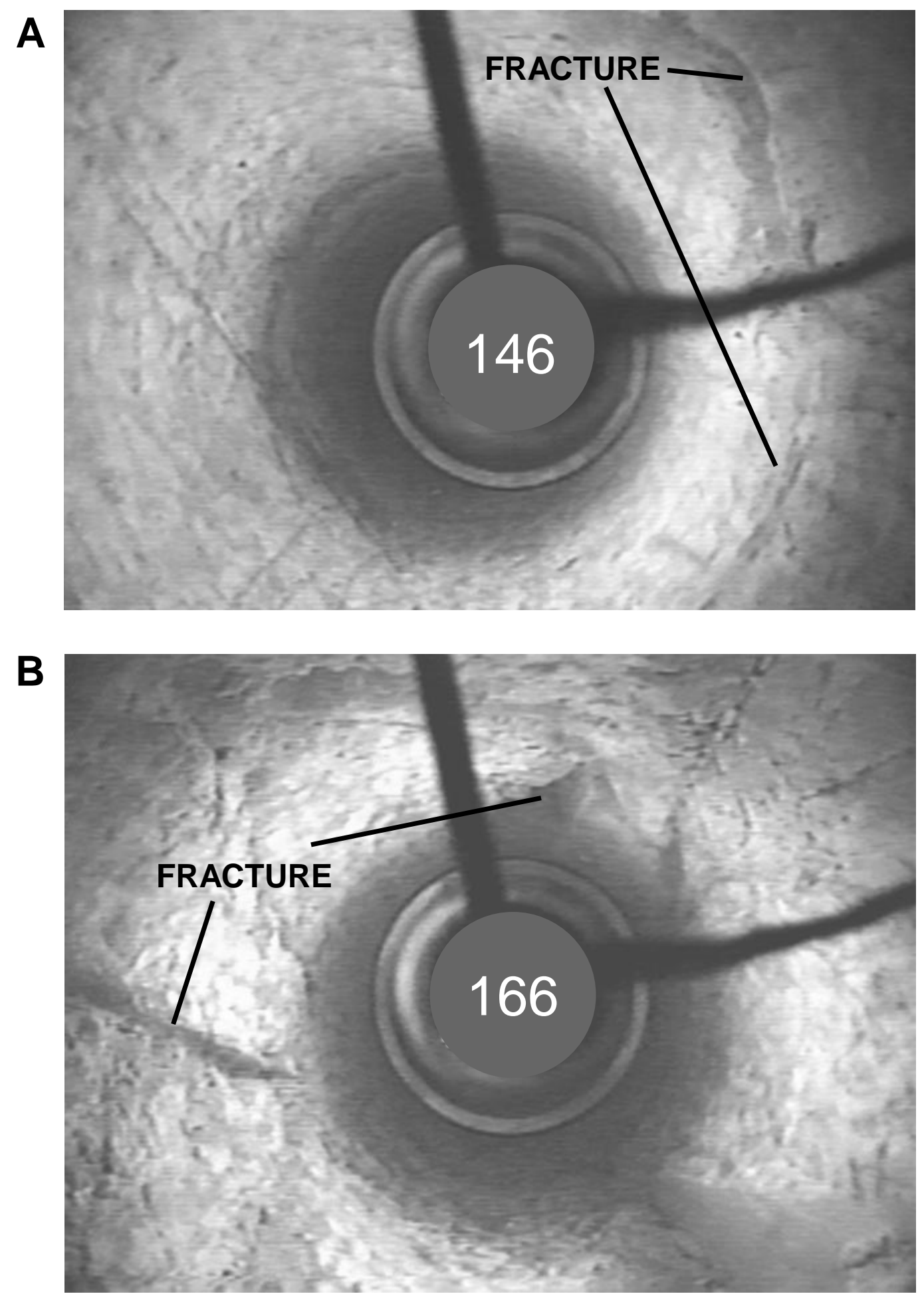

Figure 17. Images from borehole television survey showing fractures in well CC-19, Malvern TCE Site, Chester County, Pennsylvania. (A) 146 feet below land surface. (B) 166 feet below land surface. 


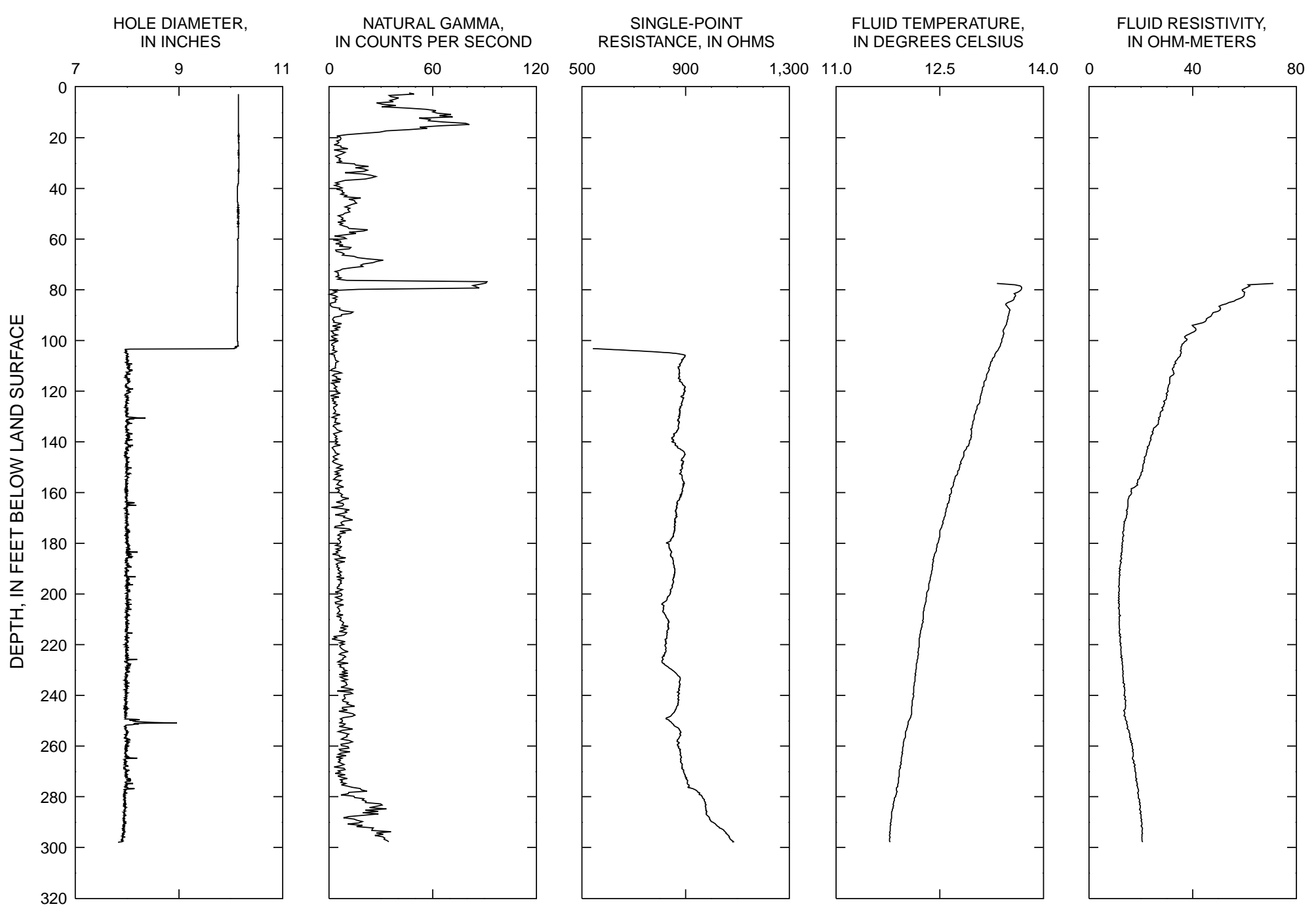

Figure 18. Borehole geophysical logs for well CC-20, Malvern TCE Site, Chester County, Pennsylvania. 


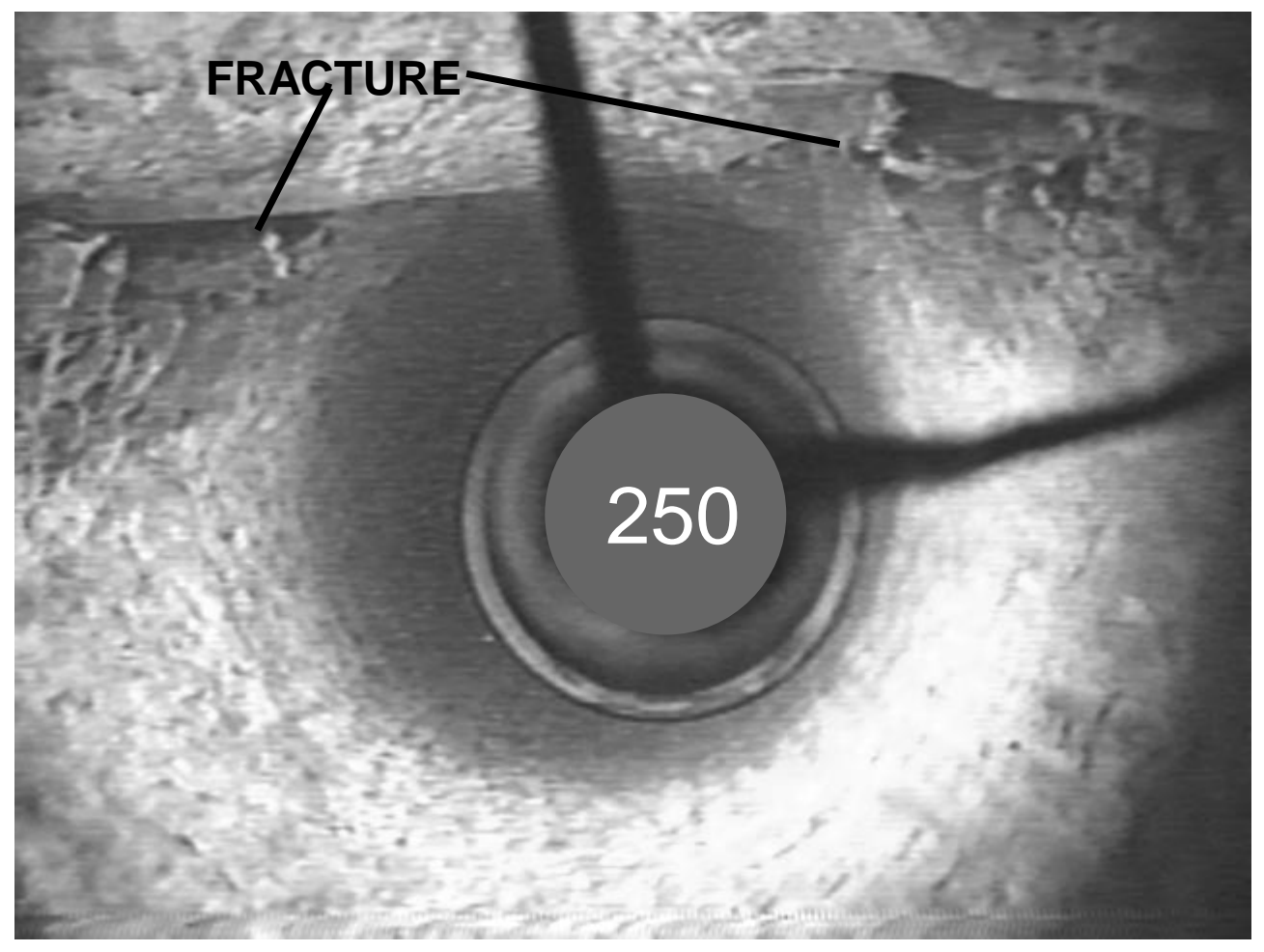

Figure 19. Image from borehole television survey showing fracture at 250 feet below land surface in well CC-20, Malvern TCE Site, Chester County, Pennsylvania.

\section{CC-21}

Well CC-21 was originally drilled to a depth of $183 \mathrm{ft}$. During drilling, the well rapidly filled with material from a large solution opening at $105 \mathrm{ft}$ bls, and the driller could not keep the hole open. The well was completed as a screened monitor well, and only a natural-gamma log was run (fig. 20). The naturalgamma log shows that the weathered (clay) zone overlying bedrock is about $48 \mathrm{ft}$ thick, and clay-filled fractures are present at 74-80 and 88-96 ft bls.

\section{CC-22}

Well CC-22 was originally drilled to a depth of $303 \mathrm{ft}$ bls. A large solution opening, shown by the caliper log (fig. 21), was penetrated at 106-114 ft bls. This opening was the only water-bearing zone penetrated. Material entering the well from this opening began filling the well soon after drilling stopped. The well was $288 \mathrm{ft}$ deep at the time of logging a few days later. The natural-gamma log shows that the thickness of the weathered (clay) zone overlying bedrock is about $86 \mathrm{ft}$ thick. The naturalgamma log does not show the opening at 106-114 ft bls as clay-filled; the borehole television survey showed it to be an open solution channel (fig. 22). It produces about $2 \mathrm{gal} / \mathrm{min}$ of turbid water. The fluid-temperature and fluid-resistivity logs do not indicate vertical borehole flow.

\section{CC-23}

Well CC-23 was originally drilled to a depth of $282 \mathrm{ft}$. A minor water-bearing zone was penetrated at $100 \mathrm{ft}$ bls, and a $10 \mathrm{gal} / \mathrm{min}$ water-bearing zone was penetrated at $272 \mathrm{ft}$ bls. A large, mud filled fracture or solution channel producing approximately $200 \mathrm{gal} / \mathrm{min}$ of turbid water was penetrated at 279-282 ft bls; this zone collapsed after drilling. The caliper $\log$ (fig. 23), which was run 2 days after completion of drilling, shows that the well collapsed to $254 \mathrm{ft}$ bls. The natural-gamma log shows that the weathered (clay) zone overlying bedrock is $75 \mathrm{ft}$ thick. The fluid-temperature and fluid-resistivity logs do not indicate vertical borehole flow. 


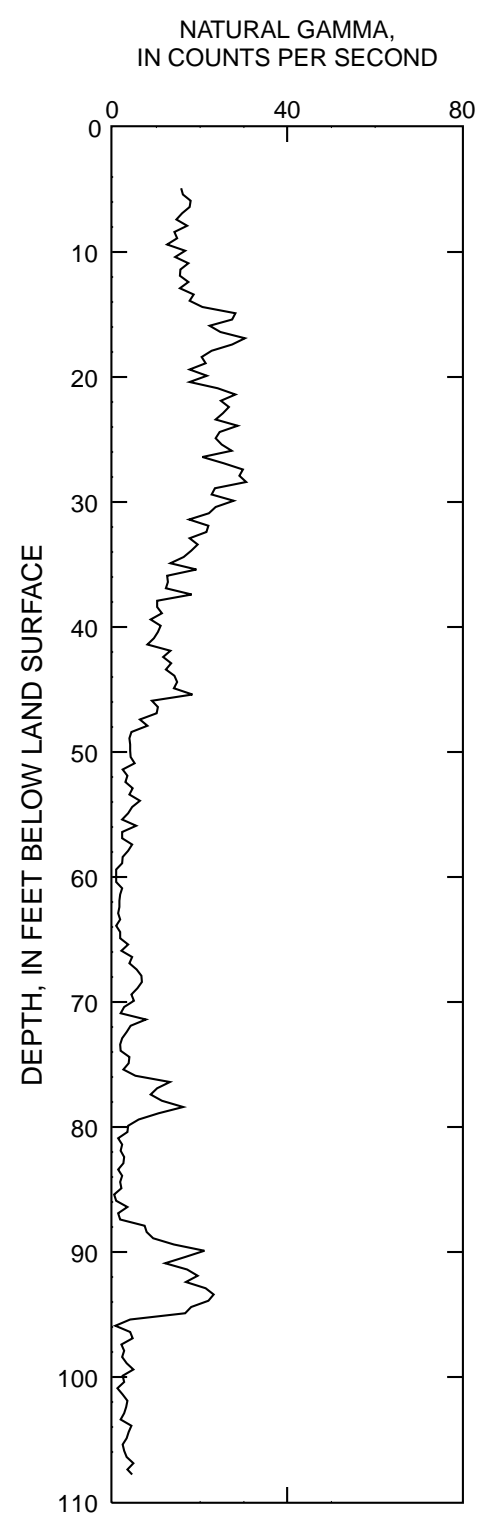

Figure 20. Natural-gamma log for well CC-21, Malvern TCE Site, Chester County, Pennsylvania. 

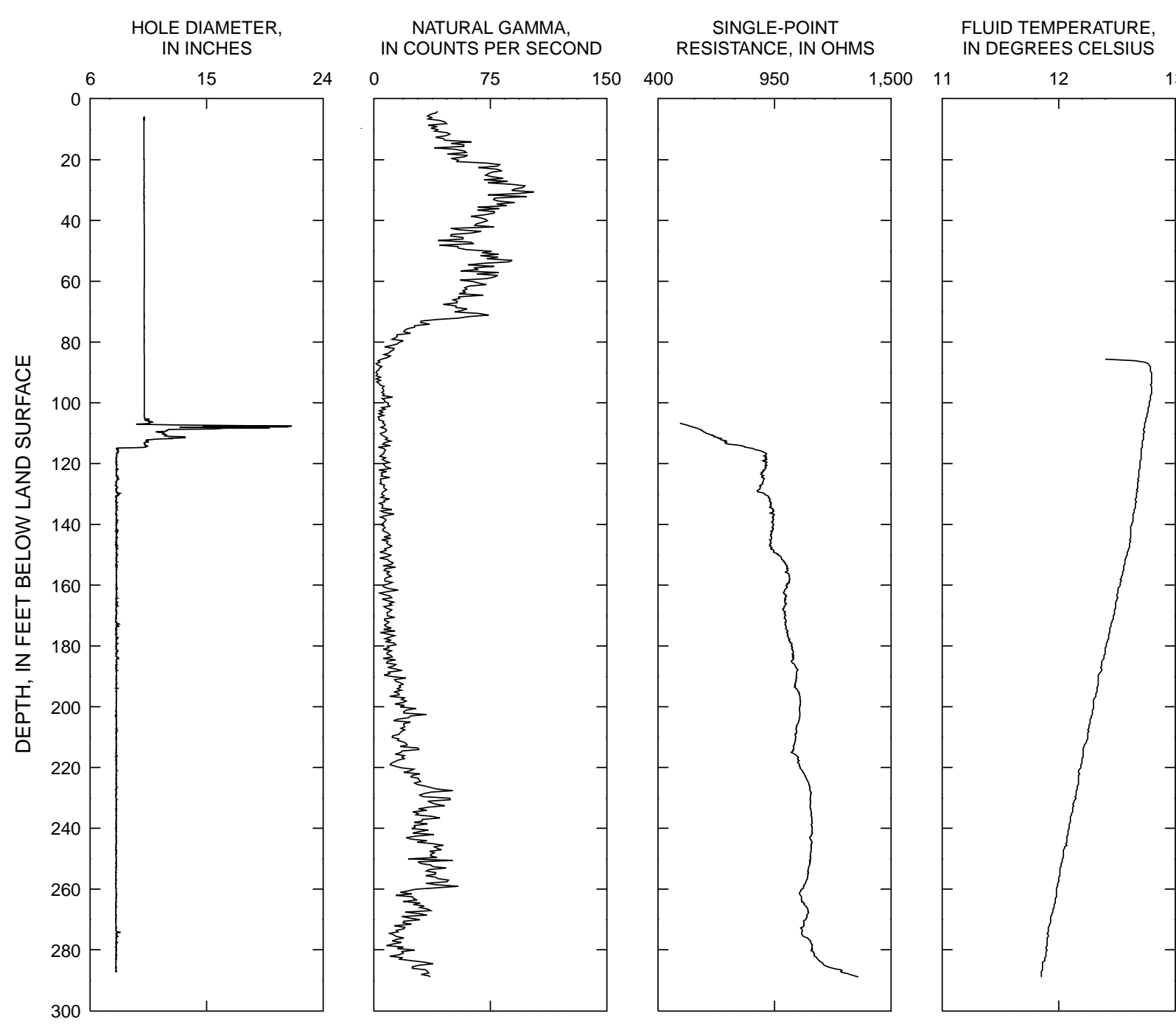

FLUID RESISTIVITY,
IN OHM-METERS

$\begin{array}{lllllll}0 & 75 & 150 & 400 & 950 & 1,500 & 11\end{array}$

$11 \quad 13$
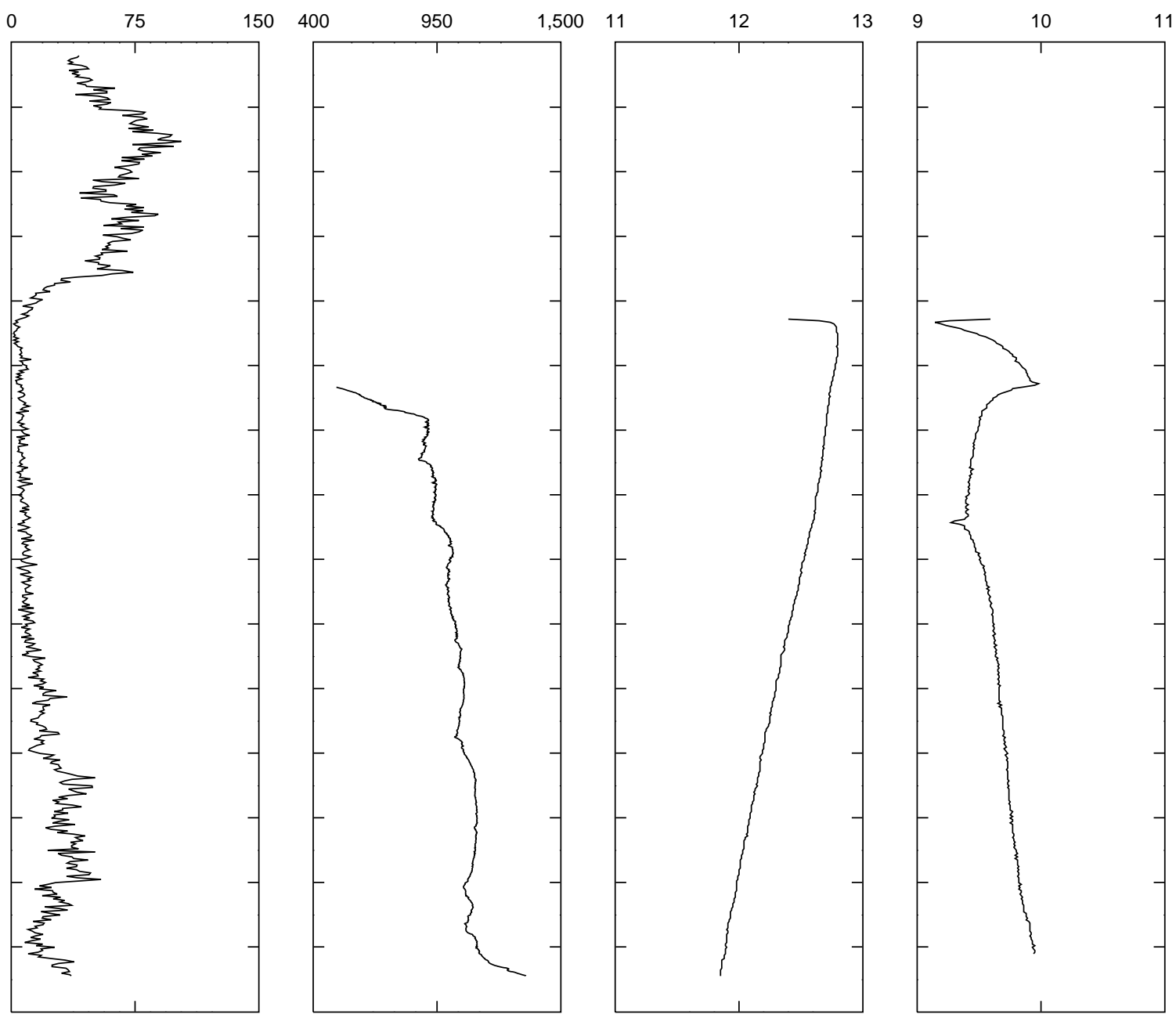

Figure 21. Borehole geophysical logs for well CC-22, Malvern TCE Site, Chester County, Pennsylvania 

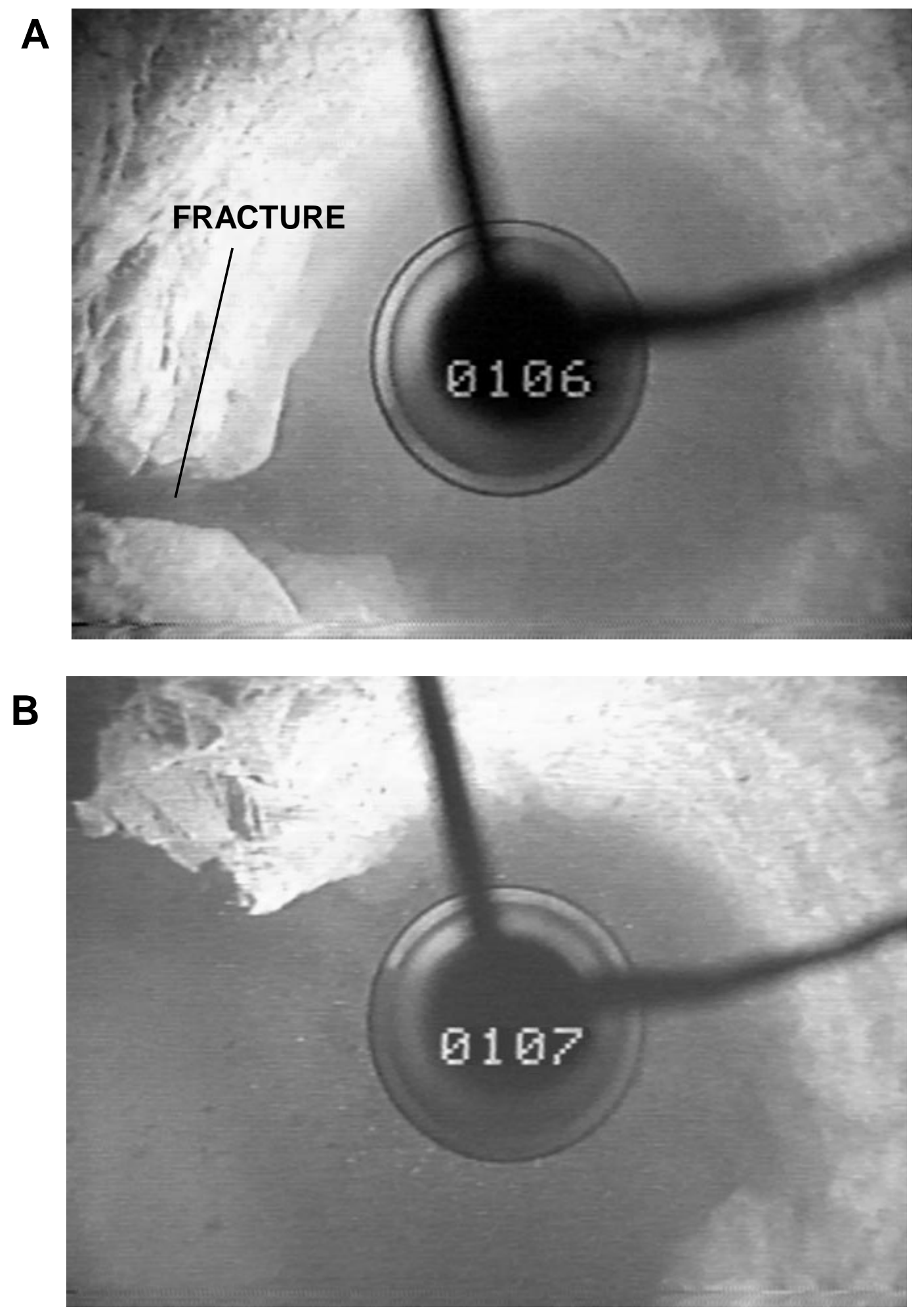

Figure 22. Images from borehole television survey showing fracture in well CC-22, Malvern TCE Site, Chester County, Pennsylvania. (A) 106 feet below land surface. (B) 107 feet below land surface. 


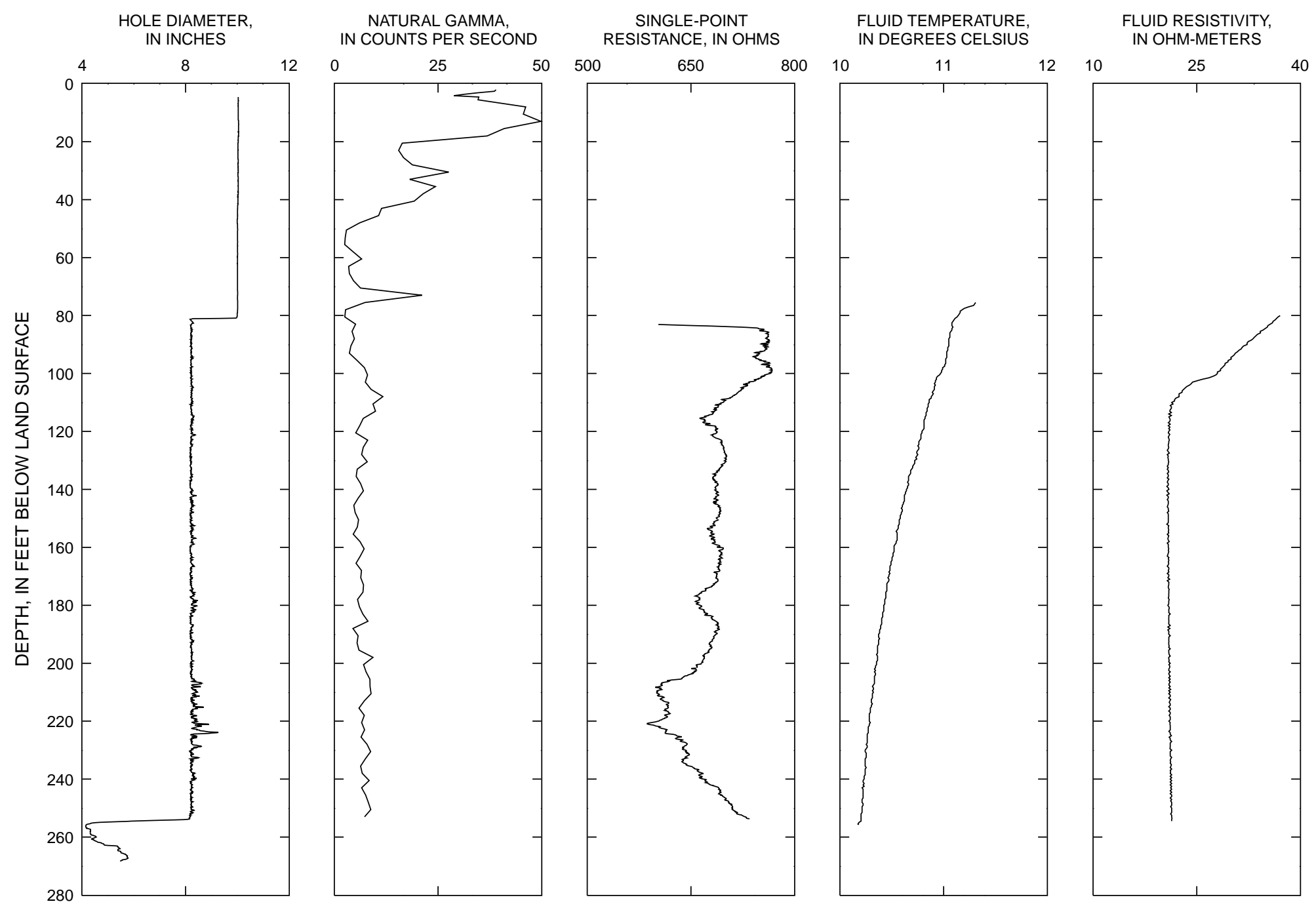

Figure 23. Borehole geophysical logs for well CC-23, Malvern TCE Site, Chester County, Pennsylvania. 


\section{Results of AQUifer Tests}

Wells CC-19 and CC-21 (fig. 10) were selected for aquifer testing on the basis of yield and VOC concentrations. A 24-hour aquifer test was run in each well.

\section{CC-19}

Because two distinct water-bearing zones were penetrated by well CC-19, an aquifer-isolation test was conducted on May 2, 1996, to determine the yield and VOC concentration of water from each zone. An inflatable packer was used to isolate the two discrete water-bearing zones. Water-bearing zones reported during drilling and confirmed with borehole geophysical logs are at 145 and $166 \mathrm{ft}$ bls (fig. 16). Inflation of the packer created two zones-one above the packer (upper zone) and one below the packer (lower zone) (fig. 24). Water levels measured in both zones after water levels had stabilized showed a difference of $0.15 \mathrm{ft}$. The water level was higher in the lower zone than in the upper zone, indicating flow from the lower to the upper zone, which confirmed the heat-pulse-flowmeter measurements.

First, the lower zone was pumped for 80 minutes and then allowed to recover for 34 minutes. This zone was pumped at $7 \mathrm{gal} / \mathrm{min}$, the maximum pumping rate of the 2-in.-diameter submersible pump that was used, with $5.69 \mathrm{ft}$ of drawdown. The specific capacity was $1.23(\mathrm{gal} / \mathrm{min}) / \mathrm{ft}$ (table 2). Drawdown measured in the upper zone was $2.38 \mathrm{ft}$, indicating a hydraulic connection between the upper and lower zones outside the borehole.

After recovery of the water levels from the lower zone test, the upper zone was pumped for 62 minutes. This zone produced $5.1 \mathrm{gal} / \mathrm{min}$ of water with $41.02 \mathrm{ft}$ of drawdown. The specific capacity was $0.12(\mathrm{gal} / \mathrm{min}) / \mathrm{ft}$. Drawdown measured in the lower zone was $1.57 \mathrm{ft}$.

Each zone was sampled near the end of each test. Results of chemical analyses are given in appendix 6 , table 1 . Because the concentrations of TCE were similar for each zone $(144 \mu \mathrm{g} / \mathrm{L}$ in the upper zone and

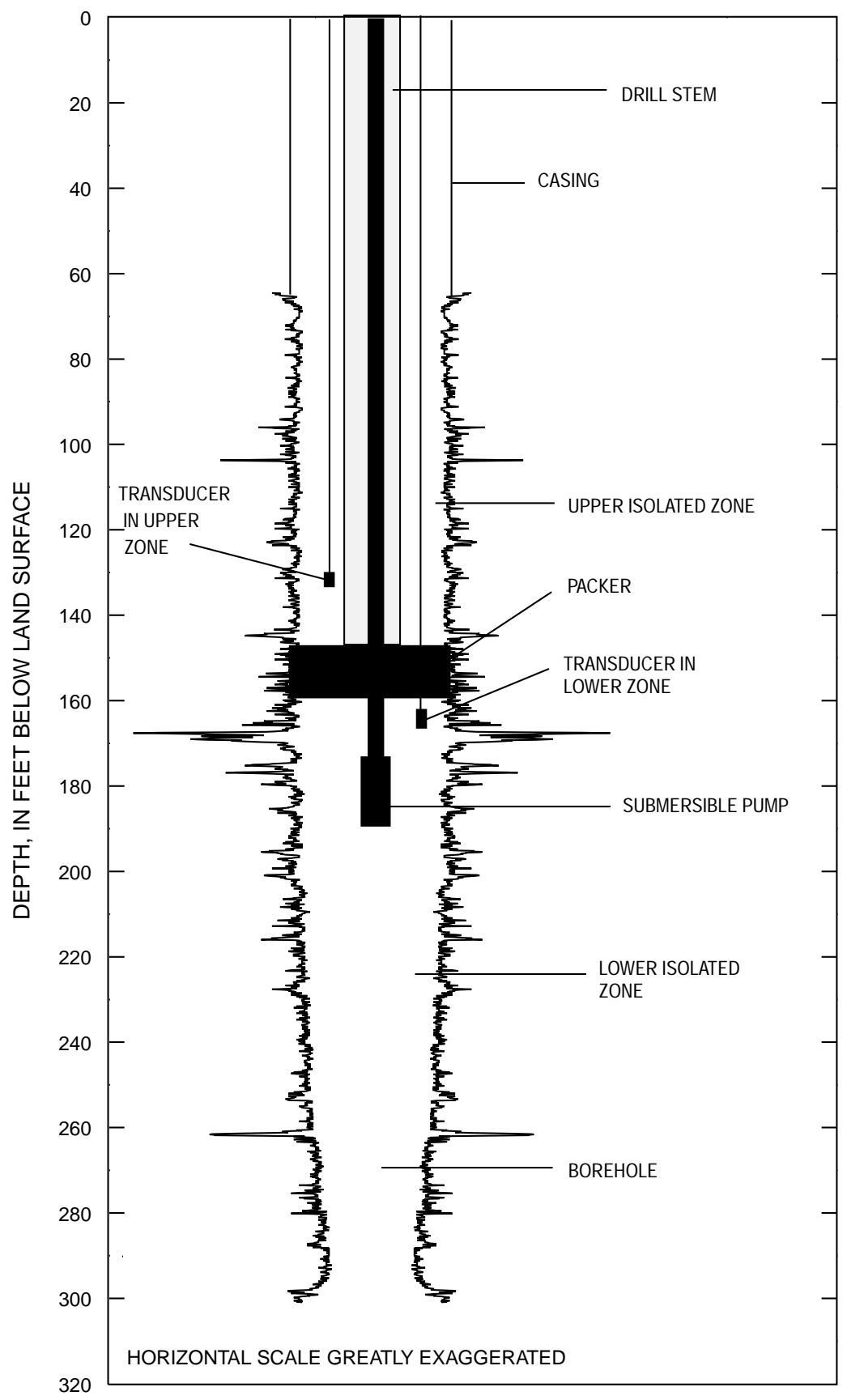

Figure 24. Diagram showing packer, pump, and transducers in well CC-19, Malvern TCE Site, Chester County, Pennsylvania. 
Table 2. Specific capacity from aquifer tests, Malvern TCE Site, Chester County, Pennsylvania [gal/min, gallons per minute; (gal/min)/ft, gallons per minute per foot of drawdown; --, no data]

\begin{tabular}{|c|c|c|c|c|c|c|}
\hline $\begin{array}{c}\text { Site well- } \\
\text { identification } \\
\text { number }\end{array}$ & Date of test & $\begin{array}{l}\text { Screened or open } \\
\text { interval (feet below } \\
\text { land surface) }\end{array}$ & $\begin{array}{l}\text { Pumping rate } \\
\text { (gal/min) }\end{array}$ & $\begin{array}{l}\text { Pumping } \\
\text { duration } \\
\text { (minutes) }\end{array}$ & $\begin{array}{l}\text { Drawdown } \\
\text { (feet) }\end{array}$ & $\begin{array}{c}\text { Specific } \\
\text { capacity } \\
{[(\text { gal } / \text { min }) / f t]}\end{array}$ \\
\hline \multicolumn{7}{|l|}{ Plant area } \\
\hline CC-19 - Upper zone & $5 / 2 / 96$ & $0-152.5$ & 5.1 & 62 & 41.02 & 0.12 \\
\hline \multirow[t]{2}{*}{ CC-19 - Lower zone } & $5 / 2 / 96$ & $152.5-303$ & 7 & 80 & 5.69 & 1.2 \\
\hline & $5 / 21-22 / 96$ & $140-180$ & 20.8 & 1,450 & 35.01 & .59 \\
\hline CC-20 & $4 / 22 / 96$ & $243-253$ & 5.6 & 67 & 73.74 & .08 \\
\hline \multirow[t]{2}{*}{ CC-21 } & $4 / 22 / 96$ & $99-109$ & 15.2 & 166 & 6.35 & 2.4 \\
\hline & $5 / 23-24 / 96$ & & 15.6 & 1,450 & 16.03 & .97 \\
\hline CC-22 & $4 / 22 / 96$ & $103.5-113.5$ & 1.6 & 60 & 9.20 & .17 \\
\hline \multicolumn{7}{|l|}{ Disposal area } \\
\hline CC-5 & $12 / 8-9 / 92$ & -- & 24 & 2,880 & 2.41 & 10 \\
\hline CC-15 & $4 / 15 / 96$ & $129-139$ & 18 & 25 & .69 & 26 \\
\hline \multirow[t]{2}{*}{$\mathrm{CC}-16$} & $4 / 17 / 96$ & $119-129$ & 20.8 & 70 & 5.80 & 3.6 \\
\hline & $5 / 14-15 / 96$ & & 39.6 & 1,450 & 19.33 & 2.0 \\
\hline \multirow[t]{2}{*}{ CC-17 } & $4 / 17 / 96$ & $105.5-115.5$ & 17.5 & 49 & .07 & 250 \\
\hline & $5 / 16-17 / 96$ & & 43.2 & 1,450 & .28 & 150 \\
\hline CC-18 & $4 / 17 / 96$ & $184-194$ & 16.7 & 53 & .06 & 280 \\
\hline
\end{tabular}

$82.2 \mu \mathrm{g} / \mathrm{L}$ in the lower zone), the screened interval, from 140 to $180 \mathrm{ft}$ bls, includes both the upper and lower zone to maximize well yield.

An aquifer test of well CC-19 was conducted on May 21-22, 1996. No precipitation fell during the 3 days prior to the test or during the test. The water level in well CC-2 was fairly steady prior to the test (fig. 25). Well CC-19 was pumped for 1,450 minutes (24 hours and 10 minutes). The initial pumping rate $\mathrm{wfsas} 13.8 \mathrm{gal} / \mathrm{min}$, and drawdown stabilized within 3 minutes at about $19.3 \mathrm{ft}$ bls. After 2 hours, the pumping rate was increased to $16.6 \mathrm{gal} / \mathrm{min}$, and drawdown quickly stabilized at about $23.7 \mathrm{ft}$ bls. After 3 hours, the pumping rate was increased to $21.7 \mathrm{gal} / \mathrm{min}$, and drawdown quickly stabilized at about $35 \mathrm{ft}$ bls. The rate was held at $21.7 \mathrm{gal} / \mathrm{min}$ to the end of the test. The average pumping rate was $20.8 \mathrm{gal} / \mathrm{min}$. Specific capacity was $0.72(\mathrm{gal} / \mathrm{min}) / \mathrm{ft}$ for the first 2 hours, $0.70(\mathrm{gal} / \mathrm{min}) / \mathrm{ft}$ for the third hour, and 0.63 (gal $/ \mathrm{min}) / \mathrm{ft}$ for the final 21 hours.

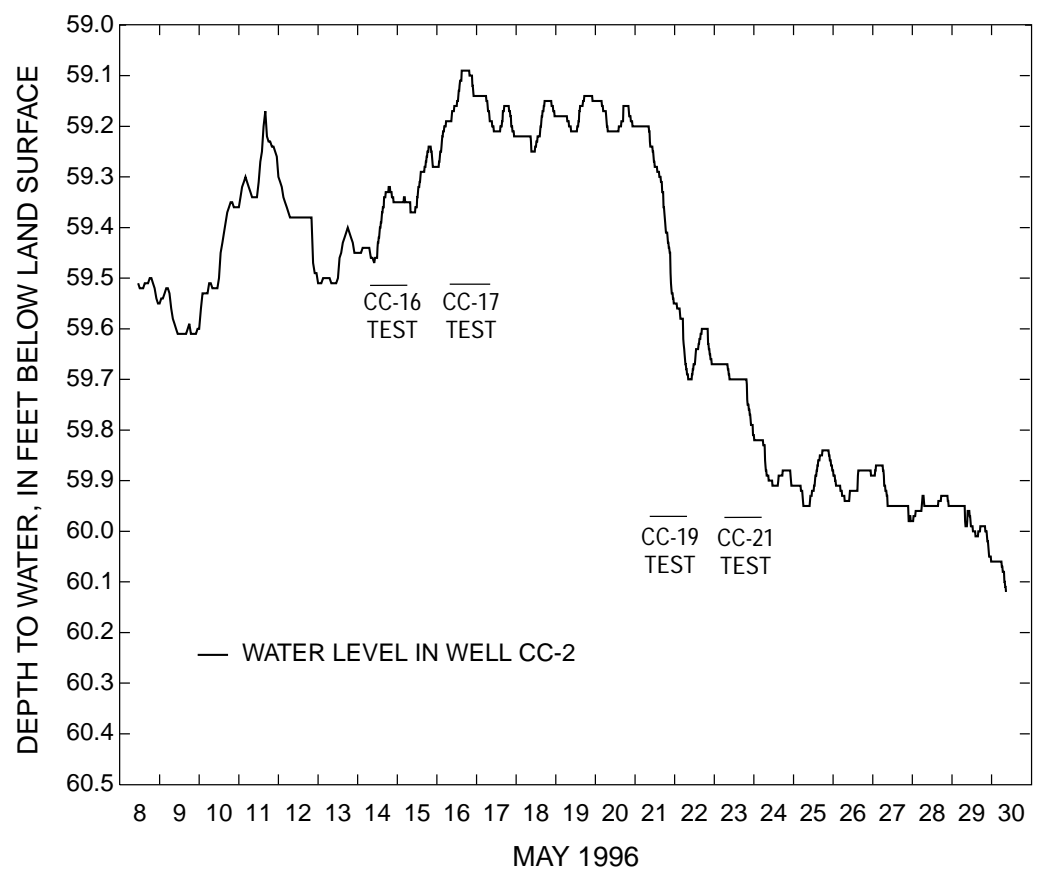

Figure 25. Hydrograph from well CC-2, May 8-30, 1996, Malvern TCE Site, Chester County, Pennsylvania. 
The maximum drawdown measured in well CC-19 was $35.01 \mathrm{ft}$ (fig. 26), and the drawdown measured in the observation wells ranged from 1.33 to $6.61 \mathrm{ft}$ (table 3). Drawdown curves for the observation wells are in appendix 4, figures 1-7. Drawdown data were not corrected for trend. The water level in well CC-2, located $378 \mathrm{ft}$ southeast of well CC-19, was affected by the pumping of well
CC-19 (fig. 24); drawdown was $0.5 \mathrm{ft}$. Transmissivity estimated from the drawdown data from well CC-19 using equations 3 and 4 is $286 \mathrm{ft}^{2} / \mathrm{d}$ (table 3 ).

Transmissivity estimated from the drawdown data from the observation wells ranges from 308 to $781 \mathrm{ft}^{2} / \mathrm{d}$ (table 3). The median transmissivity estimated from the drawdown data from all eight wells is $528 \mathrm{ft}^{2} / \mathrm{d}$.

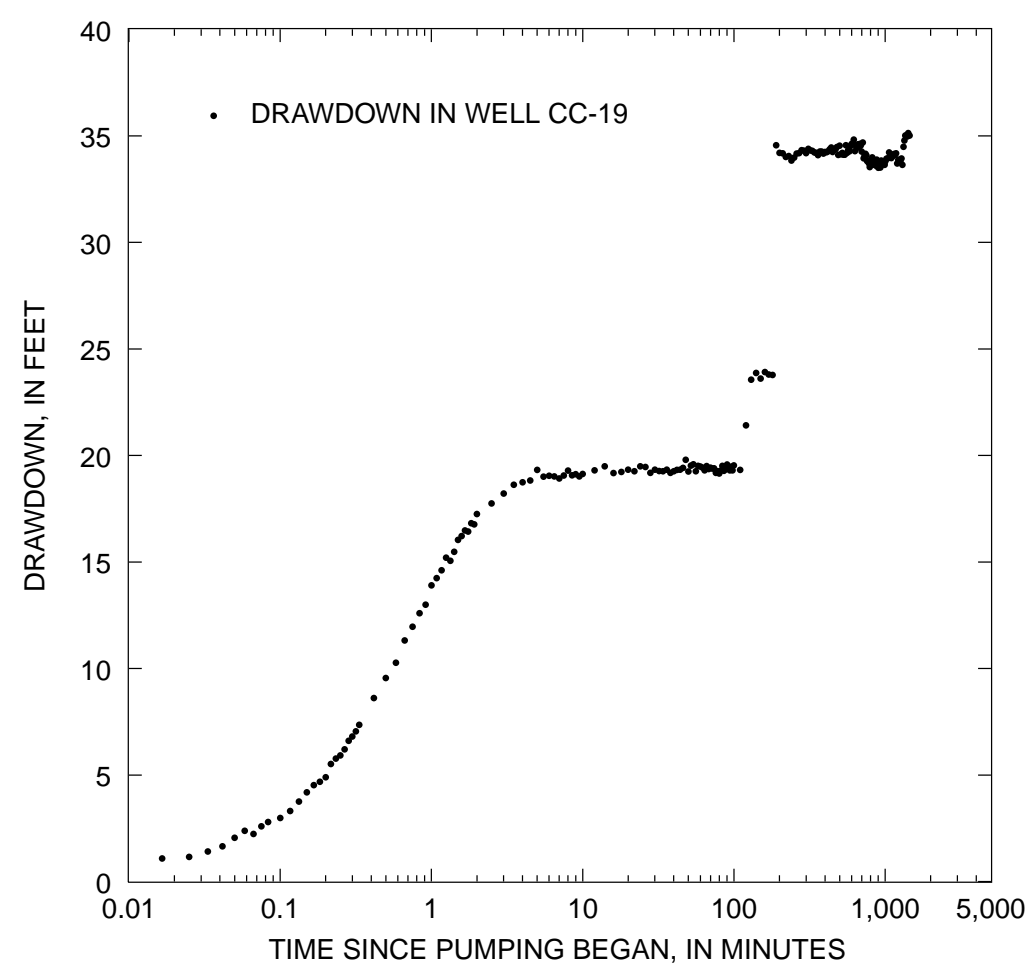

Figure 26. Relation between drawdown in well CC-19 and time for aquifer test of well CC-19, May 21-22, 1996, Malvern TCE Site, Chester County, Pennsylvania.

Table 3. Measured drawdown and estimated transmissivity for the aquifer test of well CC-19, May 21-22, 1996, Malvern TCE Site, Chester County, Pennsylvania

\begin{tabular}{|c|c|c|c|c|c|c|c|}
\hline \multirow[b]{2}{*}{$\begin{array}{c}\text { Well- } \\
\text { identification } \\
\text { number }\end{array}$} & \multirow{2}{*}{$\begin{array}{c}\text { Depth of } \\
\text { water-bearing } \\
\text { zones open } \\
\text { to well (feet } \\
\text { below land surface) }\end{array}$} & \multirow[b]{2}{*}{$\begin{array}{l}\text { Distance from } \\
\text { pumped well } \\
\text { (feet) }\end{array}$} & \multirow[b]{2}{*}{$\begin{array}{l}\text { Maximum } \\
\text { drawdown } \\
\quad(\text { feet })\end{array}$} & \multicolumn{2}{|c|}{ Drawdown data } & \multicolumn{2}{|c|}{ Recovery data } \\
\hline & & & & $\begin{array}{c}\text { Change in } \\
\text { drawdown over } \\
\text { one log cycle } \\
\text { (feet) }\end{array}$ & $\begin{array}{c}\text { Estimated } \\
\text { transmissivity } \\
\text { (feet squared } \\
\text { per day) }\end{array}$ & $\begin{array}{c}\text { Change in } \\
\text { drawdown over } \\
\text { one log cycle } \\
\text { (feet) }\end{array}$ & $\begin{array}{c}\text { Estimated } \\
\text { transmissivity } \\
\text { (feet squared } \\
\text { per day) }\end{array}$ \\
\hline \multicolumn{8}{|l|}{ Pumped well } \\
\hline CC-19 & 145,166 & -- & 35.01 & -- & 286 & 0.9 & 816 \\
\hline \multicolumn{8}{|c|}{ Observation wells } \\
\hline CC-3 & 90 & 92.5 & 1.33 & 1.38 & 532 & .58 & 1,270 \\
\hline CC- 6 & 106 & 79 & 2.49 & 1.4 & 524 & .87 & 844 \\
\hline $\mathrm{CC}-7$ & 84 & 58.5 & 3.53 & 2.38 & 308 & 1.36 & 540 \\
\hline CC-13 & 135 & 74 & 6.61 & 1.2 & 612 & .88 & 834 \\
\hline CC-20 & 250 & 78 & 4.89 & .94 & 781 & .62 & 1,180 \\
\hline CC-21 & 105 & 51.5 & 3.12 & 1.52 & 483 & 1.27 & 578 \\
\hline CC-22 & $106-114$ & 109 & 1.79 & 1.3 & 565 & .57 & 1,290 \\
\hline
\end{tabular}


Drawdown was greater in observation wells screened or open between 127 and $253 \mathrm{ft}$ bls (wells CC-13 and CC-20) than for wells screened or open from $82-113.5 \mathrm{ft}$ bls (fig. 27). Pumped well CC-19 is screened from 140-180 ft bls. Drawdown curves for wells CC-13 and CC-20 are shaped differently than drawdown curves from the shallower wells. Waterbearing fractures penetrated by observation wells are shown on figure 28. Drawdown curves for wells CC-13 and CC-20 are composed of two parts and are similar in appearance to the drawdown curve for well CC-19; they appear to reflect the change in pumping rate, which is not evident in the drawdown curves from the shallower wells. This indicates that although all the fractures in the system are hydraulically connected, the hydraulic conductivity of the deeper fracture zone is greater than the hydraulic conductivity of the upper fracture zone.

Recovery of water levels was measured for 200 to 290 minutes after pumping ceased. The recovery of the water level measured in well CC-19 is shown on figure 29. Transmissivity estimated from the recovery data from well CC-19 is $816 \mathrm{ft}^{2} / \mathrm{d}$ (table 3). Recovery curves for the observation wells are in appendix 4, figures 8-14. Transmissivity estimated from the recovery data for observation wells ranges from 540 to $1,290 \mathrm{ft}^{2} / \mathrm{d}$ (table 3). The median transmissivity estimated from the drawdown data from all eight wells is $839 \mathrm{ft}^{2} / \mathrm{d}$.

\section{CC-21}

An aquifer test of well CC-21 was conducted on May 23-24, 1996. No precipitation fell for 5 days prior to the test or during the test. Well CC-21 was pumped for 1,450 minutes (24 hours and 10 minutes) at $15.6 \mathrm{gal} / \mathrm{min}$. The water was slightly turbid for the first 2 hours of pumping. The turbidity was caused by a light tan, fine sand; X-ray diffraction analysis of this material showed it to be dolomite. The drawdown was $16.03 \mathrm{ft}$ (fig. 30), and the specific capacity was 0.97 ( $\mathrm{gal} / \mathrm{min}) / \mathrm{ft}$. The drawdown measured in the observation wells ranged from 0.74 to $2.69 \mathrm{ft}$ (table 4). Drawdown curves for the observation wells are in appendix 4, figures 15-21. The drawdown data were not corrected for trend. The water level in well CC-2, located $374 \mathrm{ft}$ southeast of well CC-21, was affected by the pumping of well CC-21 (fig. 25); drawdown was $0.21 \mathrm{ft}$. Transmissivity estimated from the drawdown data for well CC-21 is $108 \mathrm{ft}^{2} / \mathrm{d}$ (table 4).

Transmissivity estimated from the drawdown data for the observation wells ranges from 355 to $902 \mathrm{ft}^{2} / \mathrm{d}$ (table 4); the median transmissivity estimated from the drawdown data for all eight wells is $608 \mathrm{ft}^{2} / \mathrm{d}$.

Recovery of water levels was measured for 310 to 520 minutes after pumping ceased. The recovery of water levels measured in well CC-21 is shown on figure 31. Transmissivity estimated from the recovery data for well CC-21 is $220 \mathrm{ft}^{2} / \mathrm{d}$ (table 4). Recovery curves for the observation wells are in appendix 4 ,

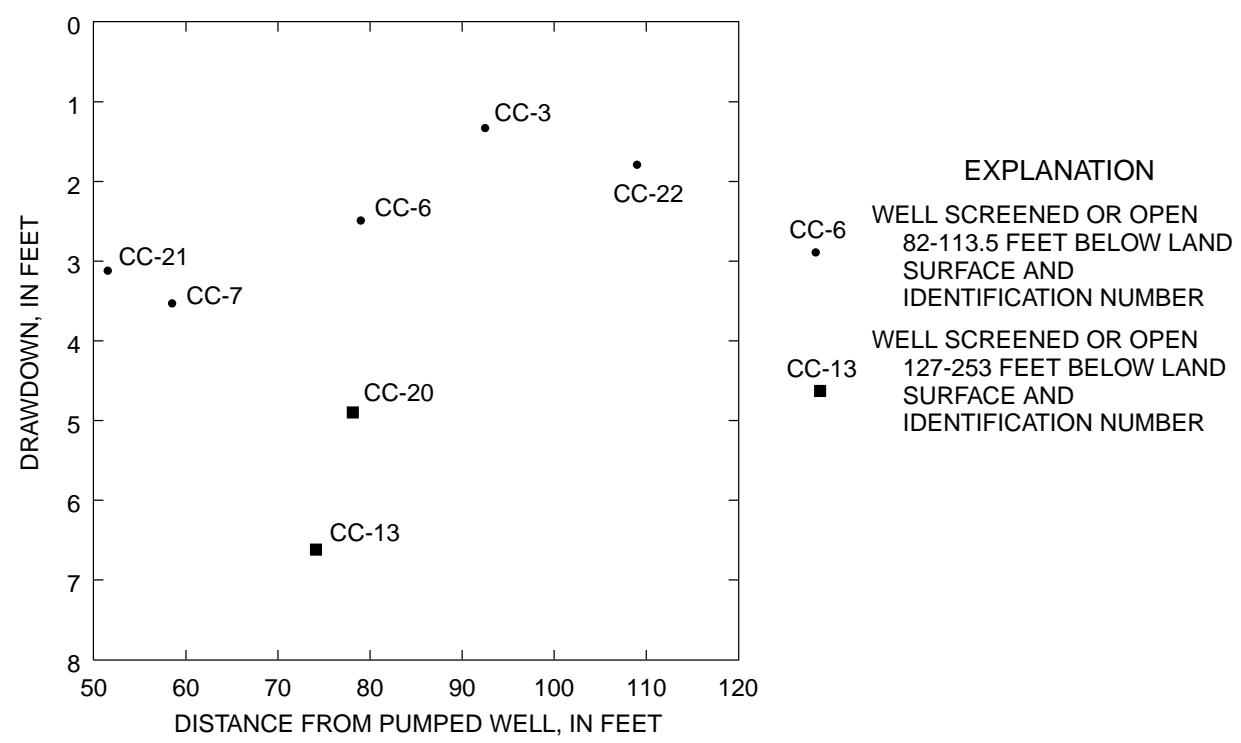

Figure 27. Relation between drawdown in observation wells and distance for aquifer test of well CC-19, May 21-22, 1996, Malvern TCE Site, Chester County, Pennsylvania. Drawdown is after 1,450 minutes of pumping. 


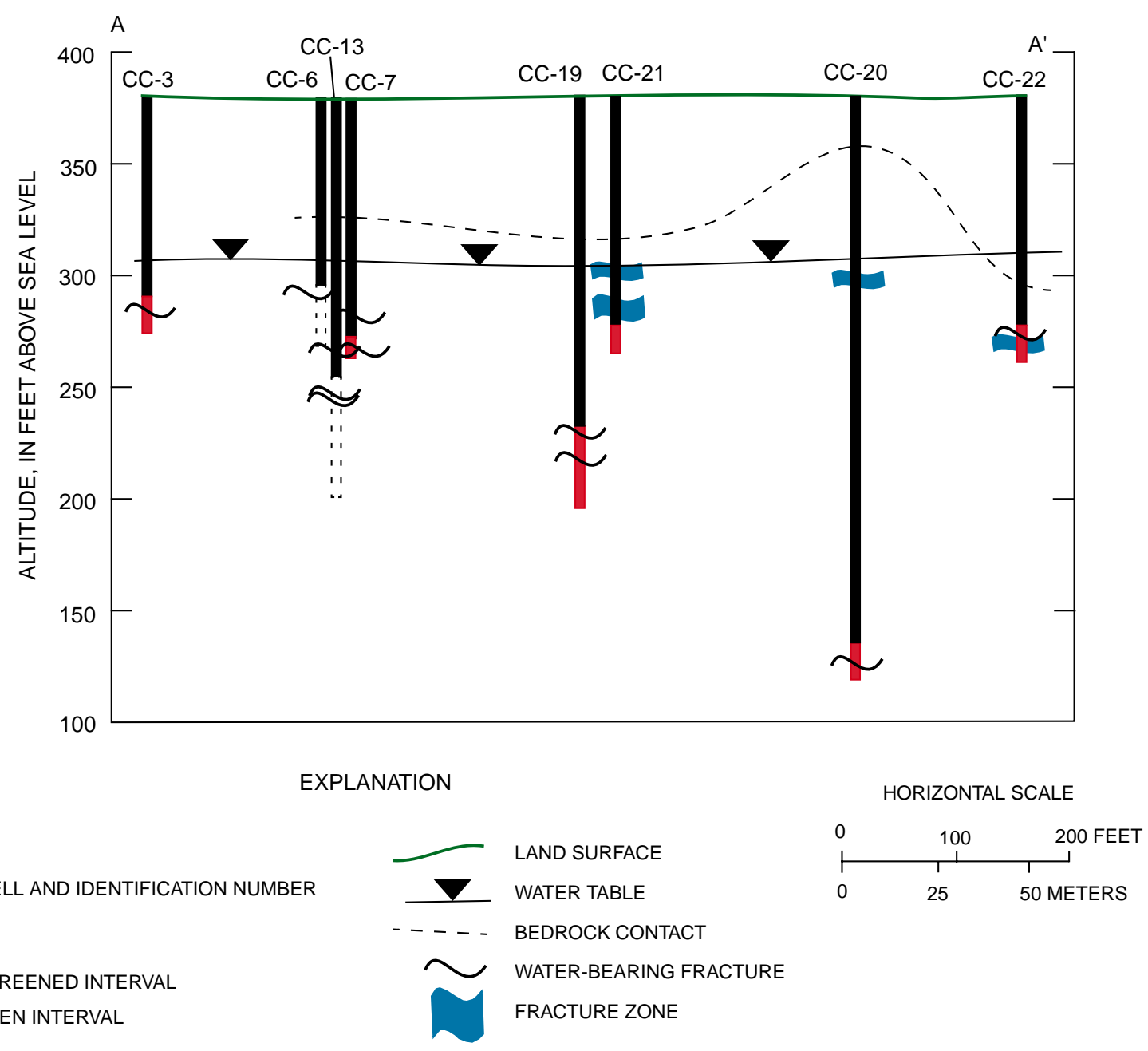

Figure 28. Generalized cross-section of the plant area, Malvern TCE Site, Chester County, Pennsylvania. Line of section is shown on figure 10.

Table 4. Measured drawdown and estimated transmissivity for the aquifer test of well CC-21, May 23-24, 1996, Malvern TCE Site, Chester County, Pennsylvania

\begin{tabular}{|c|c|c|c|c|c|c|}
\hline \multirow[b]{2}{*}{$\begin{array}{c}\text { Well- } \\
\text { identification } \\
\text { number }\end{array}$} & \multirow[b]{2}{*}{$\begin{array}{l}\text { Distance from } \\
\text { pumped well } \\
\text { (feet) }\end{array}$} & \multirow[b]{2}{*}{$\begin{array}{c}\text { Maximum } \\
\text { drawdown } \\
\text { (feet) }\end{array}$} & \multicolumn{2}{|c|}{ Drawdown data } & \multicolumn{2}{|c|}{ Recovery data } \\
\hline & & & $\begin{array}{c}\text { Change in } \\
\text { drawdown over } \\
\text { one log cycle } \\
\text { (feet) }\end{array}$ & $\begin{array}{c}\text { Estimated } \\
\text { transmissivity } \\
\text { (feet squared } \\
\text { per day) }\end{array}$ & $\begin{array}{c}\text { Change in } \\
\text { drawdown over } \\
\text { one log cycle } \\
\text { (feet) }\end{array}$ & $\begin{array}{c}\text { Estimated } \\
\text { transmissivity } \\
\text { (feet squared } \\
\text { per day) }\end{array}$ \\
\hline \multicolumn{7}{|l|}{ Pumped well } \\
\hline CC-21 & -- & 16.03 & 5.1 & 108 & 2.5 & 220 \\
\hline \multicolumn{7}{|c|}{ Observation wells } \\
\hline CC-3 & 120.5 & .74 & 1.17 & 471 & .35 & 1,570 \\
\hline CC-6 & 64 & 2.69 & .89 & 619 & 1.31 & 420 \\
\hline CC-7 & 74 & 2.50 & 1.55 & 355 & 1.53 & 360 \\
\hline CC-13 & 65.5 & 2.19 & .74 & 744 & .94 & 586 \\
\hline CC-19 & 51.5 & 2.16 & .69 & 798 & .92 & 598 \\
\hline CC-20 & 96 & 1.13 & .61 & 902 & .49 & 1,120 \\
\hline CC-22 & 82.5 & .98 & .74 & 744 & .62 & 888 \\
\hline
\end{tabular}




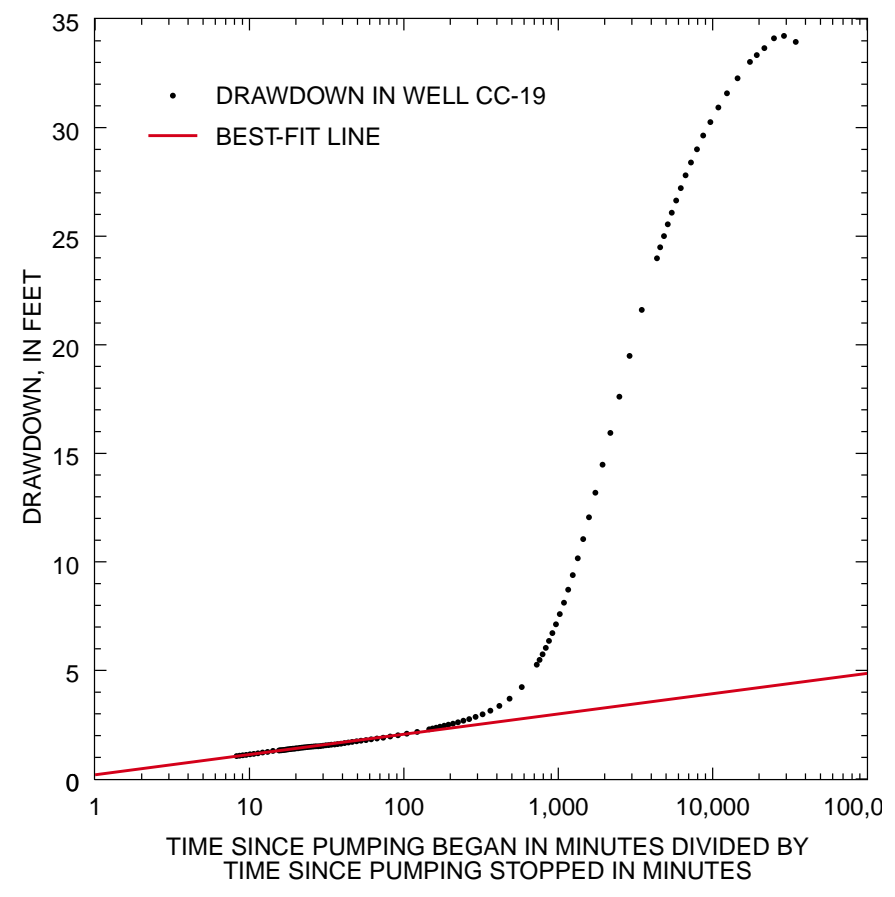

Figure 29. Relation between drawdown in well CC-19 and time for recovery phase of aquifer test of well CC-19, May 22, 1996, Malvern TCE Site, Chester County, Pennsylvania.

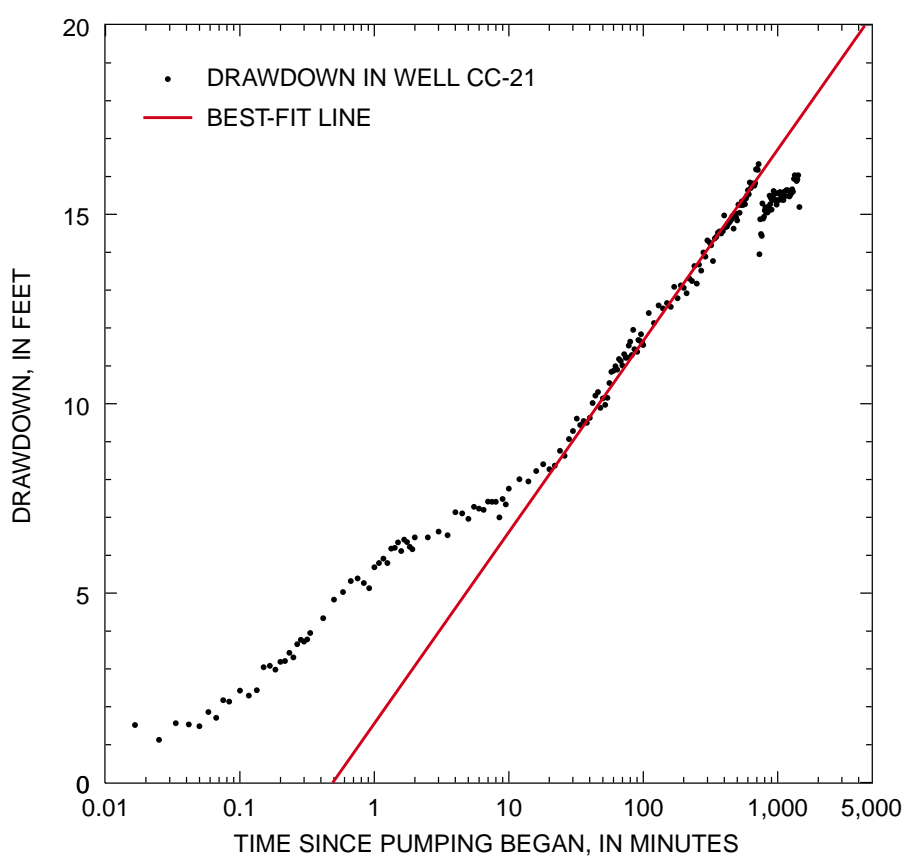

Figure 30. Relation between drawdown in well CC-21 and time for aquifer test of well CC-21, May 23-24, 1996, Malvern TCE Site, Chester County, Pennsylvania. figures 22-28. Transmissivity estimated from the recovery data for the observation wells ranges from 360 to $1,570 \mathrm{ft}^{2} / \mathrm{d}$ (table 4); the median transmissivity estimated from the recovery data for all eight wells is $588 \mathrm{ft}^{2} / \mathrm{d}$, which is very close to the median transmissivity estimated from observation well drawdown data.

\section{WATER LEVELS}

Water levels were measured continuously in wells CC-2 and CC-13. The water levels, plotted as the highest daily water level (fig. 32), show similar seasonal variations and responses to precipitation. The range of water-level fluctuation from February 1995 to April 1996 was $24.15 \mathrm{ft}$ for well CC-2 and $22.97 \mathrm{ft}$ for well CC-13. The hydrograph of well CC-2 (fig. 25) shows a minor effect of daily pumping that starts about 8:30 p.m. each day. The pumping causes a drawdown in the water level of well CC-2 of less than $0.2 \mathrm{ft}$. The source of pumping is unknown. No other hydrographs showed the effects of pumping.

Water levels were measured monthly in all on-site wells from January 1995 to May 1996. The measurements are given in appendix 5 . Water levels in wells at the plant area show a similar magnitude of fluctuation and a similar pattern of seasonal fluctuation (fig. 33). The water-level fluctuation ranged from $21.18 \mathrm{ft}$ in well CC-6 to $22.97 \mathrm{ft}$ in well CC-2.

\section{Distribution of Volatile ORGANiC COMPOUNDS}

The concentrations of VOC's in ground water at the plant area are higher than concentrations at the disposal area (table 5). Concentrations of selected detected compounds are presented in table 5; the complete analyses are given in appendix 6 , table 2 . Water samples collected from wells at the plant area in May 1996 had maximum concentrations of TCE of $53,900 \mu \mathrm{g} / \mathrm{L}, \mathrm{PCE}$ of $7,110 \mu \mathrm{g} / \mathrm{L}$, and TCA of $17,700 \mu \mathrm{g} / \mathrm{L}$ (fig. 34). The highest concentrations of TCE and TCA were in water from well CC-6; the highest concentration of PCE was in water from well CC-7. Concentrations of VOC's are lower in water from well CC-2, which is upgradient, and well CC-13. Well CC-13 is $180 \mathrm{ft}$ deep, cased to $125 \mathrm{ft}$ bls, and penetrates a water-bearing zone $135 \mathrm{ft}$ bls; it is the deepest 


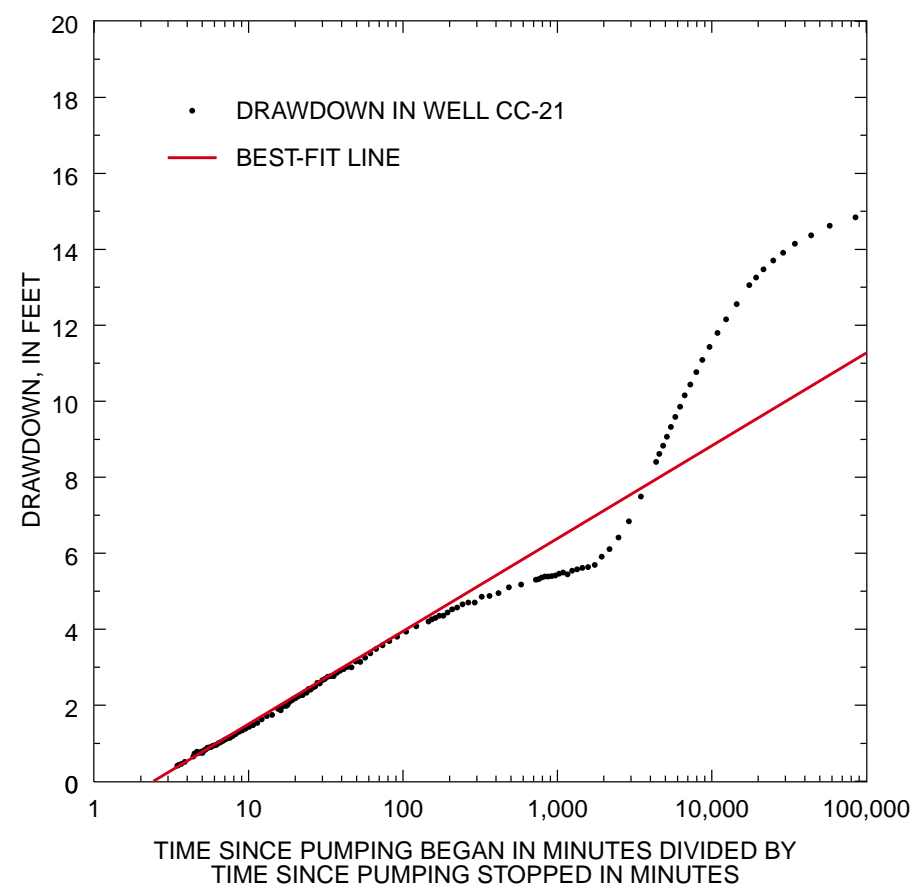

Figure 31. Relation between drawdown in well CC-21 and time for recovery phase of aquifer test of well CC-21, May 24, 1996, Malvern TCE Site, Chester County, Pennsylvania.

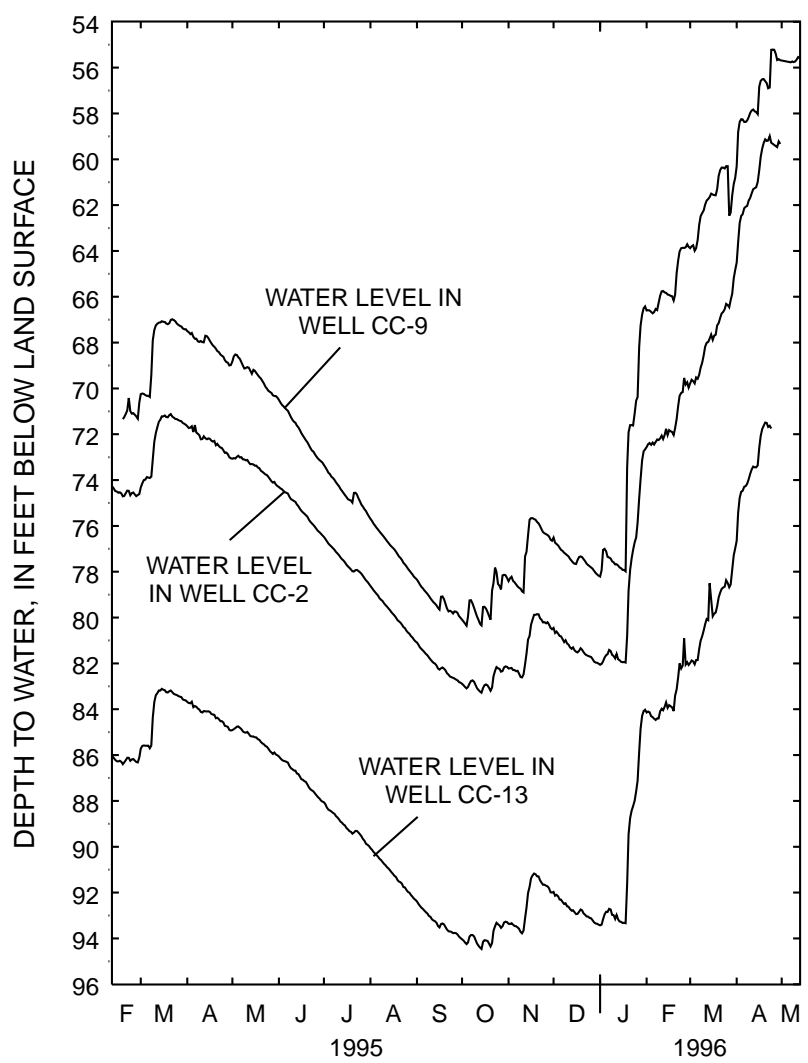

Figure 32. Hydrographs from wells CC-2, CC-9, and CC-13, February 1995 to May 1996, Malvern TCE Site, Chester County, Pennsylvania. well at the plant. Concentrations of VOC's in water from wells CC-19, CC-20, CC-21, and CC-22 drilled northeast and downgradient of the plant property boundary are one to two orders of magnitude less than concentrations in water from wells less than $100 \mathrm{ft}$ away at the plant. This indicates that a relatively low concentration (less than $600 \mu \mathrm{g} / \mathrm{L}$ ) plume of VOC's extends off site.

The water sample from well CC-7 suggests more biodegradation than water samples from the other plant area wells. The water sample from well CC-7 contains a much higher ratio of dehalogenation product cis-1,2-dichloroethylene to TCE than water from the other wells, and it is the only water sample containing detectable concentrations of dehalogenation products vinyl chloride and chloroethane.

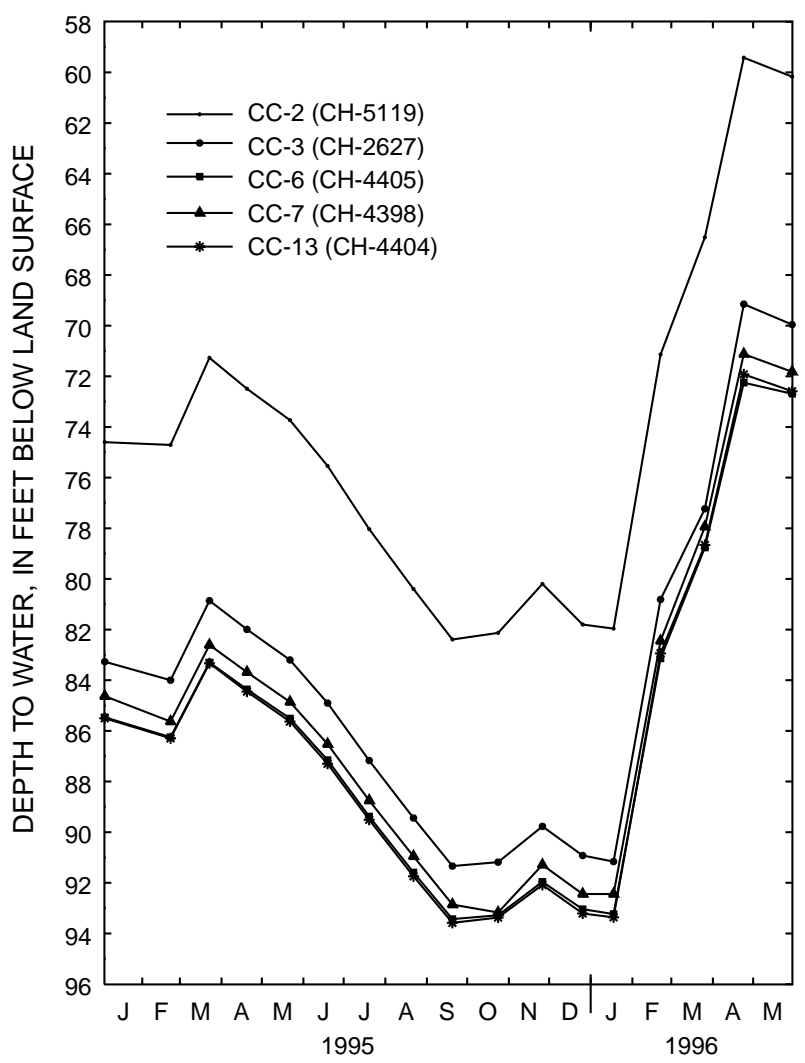

Figure 33. Hydrographs (depth to water) from wells measured monthly at the plant area, January 1995 to May 1996, Malvern TCE Site, Chester County, Pennsylvania. 
Table 5. Results of chemical analyses for selected volatile organic compounds detected in water samples from on-site wells, 1996, Malvern TCE Site, Chester County, Pennsylvania

[Data provided by L.R. Dietz (U.S. Environmental Protection Agency, written commun., 1996); concentrations in micrograms per liter; $<$, less than; J, estimated concentration; C, concentration reported from diluted sample]

\begin{tabular}{|c|c|c|c|c|c|c|c|c|c|c|}
\hline $\begin{array}{l}\text { Site well- } \\
\text { identification } \\
\text { number }\end{array}$ & $\begin{array}{l}\text { U.S. Geological } \\
\text { Survey well- } \\
\text { identification } \\
\text { number }\end{array}$ & $\begin{array}{c}\text { Date } \\
\text { analyzed }\end{array}$ & $\begin{array}{l}\text { 1,1-Di- } \\
\text { chloro- } \\
\text { ethane }\end{array}$ & $\begin{array}{l}\text { 1,2-Di- } \\
\text { chloro- } \\
\text { ethane }\end{array}$ & $\begin{array}{l}1,1-\mathrm{Di}- \\
\text { chloro- } \\
\text { ethene }\end{array}$ & $\begin{array}{l}\text { cis-1,2- } \\
\text { Dichloro- } \\
\text { ethylene }\end{array}$ & $\begin{array}{l}\text { Tetrachloro- } \\
\text { ethylene }\end{array}$ & $\begin{array}{c}1,1,1- \\
\text { Trichloro- } \\
\text { ethane }\end{array}$ & $\begin{array}{l}1,1,2- \\
\text { Trichloro- } \\
\text { ethane }\end{array}$ & $\begin{array}{l}\text { Trichloro- } \\
\text { ethylene }\end{array}$ \\
\hline \multicolumn{11}{|c|}{ Plant area wells } \\
\hline CC-2 & $\mathrm{CH}-5119$ & 05/03/96 & 8.0 & $<1$ & $<1$ & 13.2 & 4.9 & 6.5 & $0.2 \mathrm{~J}$ & 33.0 \\
\hline CC-3 & $\mathrm{CH}-2672$ & 05/03/96 & 18.8 & 2.6 & $963 \mathrm{C}$ & 290 J,C & $1,830 \mathrm{C}$ & $2,650 \mathrm{C}$ & 1.8 & $12,700 \mathrm{C}$ \\
\hline $\mathrm{CC}$ & $\mathrm{CH}-4405$ & 05/07/96 & $57 \mathrm{~J}$ & $1,130 \mathrm{C}$ & $4,230 \mathrm{C}$ & $1,280 \mathrm{C}$ & $6,200 \mathrm{C}$ & $17,700 \mathrm{C}$ & 37.5 & $53,900 \mathrm{C}$ \\
\hline CC-7 & $\mathrm{CH}-4398$ & 05/07/96 & $917 \mathrm{C}$ & $4,960 \mathrm{C}$ & $805 \mathrm{C}$ & $16,500 \mathrm{C}$ & $7,110 \mathrm{C}$ & $9,510 \mathrm{C}$ & 27.9 & $19,900 \mathrm{C}$ \\
\hline CC-13 & $\mathrm{CH}-4404$ & $05 / 07 / 96$ & $63 \mathrm{~J}$ & $184 \mathrm{C}$ & $131 \mathrm{C}$ & $434 \mathrm{C}$ & $569 \mathrm{C}$ & $509 \mathrm{C}$ & 1.6 & $1,510 \mathrm{C}$ \\
\hline CC-19 & $\mathrm{CH}-5146$ & 05/10/96 & $<1$ & $<1$ & 9.2 & 3.1 & $41.1 \mathrm{C}$ & 29.2 & $<1$ & $74.5 \mathrm{C}$ \\
\hline CC-20 & $\mathrm{CH}-5147$ & 05/07/96 & $<1$ & 1.5 & $.7 \mathrm{~J}$ & 2.6 & 3.9 & 2.4 & $<1$ & 8.5 \\
\hline CC-21 & $\mathrm{CH}-5148$ & 05/07/96 & 1.6 & 1.6 & 35.0 & 15.2 & $173 \mathrm{C}$ & $118 \mathrm{C}$ & $<1$ & $503 \mathrm{C}$ \\
\hline CC-22 & $\mathrm{CH}-5149$ & 05/07/96 & $<1$ & $.2 \mathrm{~J}$ & 1.9 & $<1$ & 5.9 & 5.9 & $<1$ & 16.7 \\
\hline \multicolumn{11}{|c|}{ Disposal area wells } \\
\hline CC-5 & $\mathrm{CH}-5121$ & 05/02/96 & 10.3 & $50.5 \mathrm{C}$ & $42.2 \mathrm{C}$ & $2,190 \mathrm{C}$ & $111 \mathrm{C}$ & $108 \mathrm{C}$ & $.6 \mathrm{~J}$ & $768 \mathrm{C}$ \\
\hline CC-9 & $\mathrm{CH}-4395$ & 05/03/96 & $<1$ & 2.2 & 1.8 & 6.0 & 7.6 & 3.7 & $<1$ & 8.1 \\
\hline CC-10 & $\mathrm{CH}-5122$ & 05/02/96 & $<1$ & $.8 \mathrm{~J}$ & $<1$ & 9.0 & 2.3 & $.4 \mathrm{~J}$ & $<1$ & 2.1 \\
\hline CC-11 & $\mathrm{CH}-5123$ & $05 / 03 / 96$ & $<1$ & $<1$ & $<1$ & $<1$ & $<1$ & $<1$ & $<1$ & $<1$ \\
\hline CC-14 & $\mathrm{CH}-5124$ & $05 / 02 / 96$ & $.4 \mathrm{~J}$ & $.5 \mathrm{~J}$ & $.7 \mathrm{~J}$ & 9.6 & $.9 \mathrm{~J}$ & 2.4 & $<1$ & 16.7 \\
\hline CC-15 & $\mathrm{CH}-5142$ & $05 / 02 / 96$ & 1.4 & 2.5 & 9.2 & 28.4 & $44.6 \mathrm{C}$ & 32.6 & $<1$ & $76.1 \mathrm{C}$ \\
\hline CC-16 & $\mathrm{CH}-5143$ & $05 / 02 / 96$ & 3.0 & 9.3 & 19.9 & $121 \mathrm{C}$ & $54.8 \mathrm{C}$ & $54.9 \mathrm{C}$ & $<1$ & $110 \mathrm{C}$ \\
\hline CC-17 & $\mathrm{CH}-5144$ & $05 / 02 / 96$ & 1.2 & 3.2 & 5.3 & $101 \mathrm{C}$ & 36.4 & 23.5 & 1.1 & $67.5 \mathrm{C}$ \\
\hline CC-18 & $\mathrm{CH}-5145$ & $05 / 02 / 96$ & $.3 \mathrm{~J}$ & 1.2 & 1.1 & 27.9 & 2.8 & 7.0 & $.6 \mathrm{~J}$ & 13.1 \\
\hline
\end{tabular}

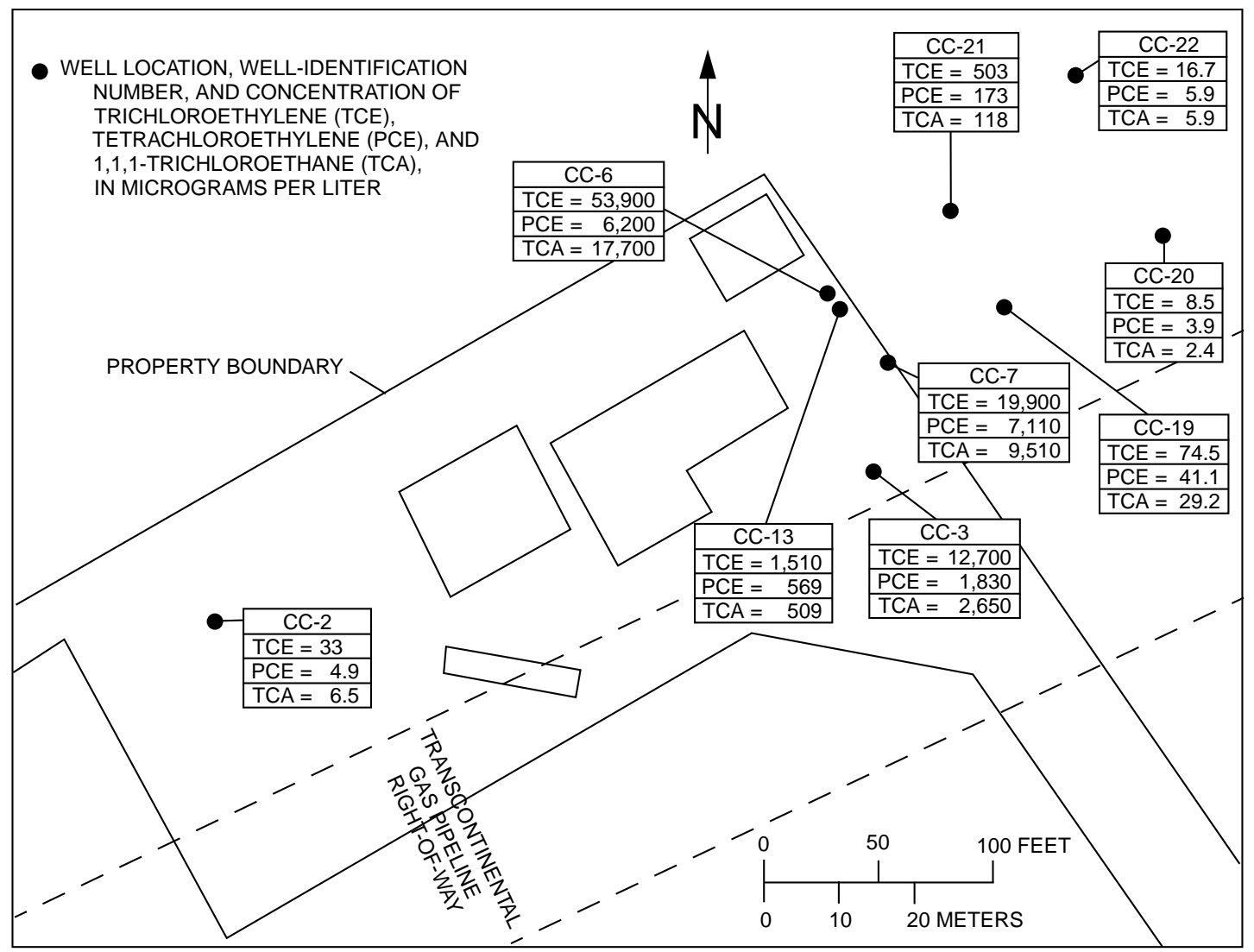

Figure 34. Concentrations of trichloroethylene, tetrachloroethylene, and 1,1,1-trichloroethane in water from wells at the plant area, May 1996, Malvern TCE Site, Chester County, Pennsylvania. 
The presence of a dense nonaqueous phase liquid (DNAPL) may be inferred if dissolved concentrations are greater than 1 percent of the solubility of the pure phase compound (Cohen and Mercer, 1993, p. 9-45). One percent of solubility is $1,500 \mu \mathrm{g} / \mathrm{L}$ for TCE, $11,000 \mu \mathrm{g} / \mathrm{L}$ for PCE, and $13,600 \mu \mathrm{g} / \mathrm{L}$ for TCA. For water samples collected in 1996 (table 5), 1 percent of solubility for TCE is exceeded in water from wells CC-3, CC-6, CC-7, and CC-13, and 1 percent of solubility for TCA is exceeded in water from well CC-6. One percent of solubility for PCE is not exceeded. The concentration of TCE in the water sample from well CC-7 is 36 percent of the solubility of TCE, which strongly suggests the presence of a DNAPL. Historical chemical analyses compiled by CH2M HILL, Inc. (1995), indicate that 1 percent of solubility for TCA was exceeded in water samples collected in 1990 from wells CC-3 and CC-7.

Water from the plant area discharges to the Catanach quarry, approximately $1.2 \mathrm{mi}$ to the northeast (pl. 1). Quarry inflow samples collected by Sloto (1987, p. 42-47) show concentrations of TCE to $200 \mu \mathrm{g} / \mathrm{L}$, PCE to $25 \mu \mathrm{g} / \mathrm{L}$, and TCA to $300 \mu \mathrm{g} / \mathrm{L}$. Concentrations of VOC's in water from well CH-2549 (fig. 1), which is between the plant area and the Catanach quarry, were $19 \mu \mathrm{g} / \mathrm{L}$ of TCE, less than $3 \mu \mathrm{g} / \mathrm{L}$ of PCE, and $34 \mu \mathrm{g} / \mathrm{L}$ of TCA (Sloto, 1987, p. 43). These concentrations are similar to concentrations in water from wells drilled for this study immediately downgradient of the plant and are lower than concentrations in the quarry inflow samples. It is not known if a plume of VOC's extends from the plant area to the Catanach quarry or if another source or sources are contributing to the VOC's detected in quarry inflow samples. Unfortunately, few wells have been drilled between the plant area and the Catanach quarry.

\section{HYDROGEOLOGIC FRAMEWORK}

The plant area is underlain by dolomite of the Elbrook Formation. The dolomite at the plant area is less fractured than the dolomite at the disposal area, which is underlain by the Ledger Dolomite. The mean thickness of the weathered (clay) zone overlying bedrock determined from natural-gamma logs is $55 \mathrm{ft}$, which is similar to that of the disposal area $(58 \mathrm{ft})$. In the three wells drilled at the plant area for this study that did not collapse, only one water-bearing zone in two wells and two water-bearing zones in one well were penetrated to a depth of $303 \mathrm{ft}$ bls. The mean depth to water measured on May 30, 1996, was $70.32 \mathrm{ft}$.
The dolomite at the plant area does not yield as much water as the dolomite at the disposal area because it is less fractured. Yields of 9 wells at the plant area range from 1 to $200 \mathrm{gal} / \mathrm{min}$, and the median yield is $6 \mathrm{gal} / \mathrm{min}$. Specific capacities and transmissivities are lower at the plant area than at the disposal area. Specific capacity for wells at the plant area range from 0.08 to $2(\mathrm{gal} / \mathrm{min}) / \mathrm{ft}$.

Transmissivity estimated from aquifer-test data for well CC-19 is 528 and $839 \mathrm{ft}^{2} / \mathrm{d}$ for drawdown and recovery data, respectively. Well CC-19 is screened from 140-180 ft bls, and this zone is better connected to the deeper fractures penetrated by wells CC-13 (135 ft bls) and CC-20 (250 ft bls) than to shallower fractures penetrated by the other observation wells. Transmissivity estimated from aquifer-test data for well CC-21 is 608 and $588 \mathrm{ft}^{2} / \mathrm{d}$ for drawdown and recovery data, respectively. Well CC-21 is screened from 99-109 ft bls and is open to the shallower fracture zone penetrated by observation wells CC-3 (90 ft bls), CC-6 (106 ft bls), CC-7 (84 ft bls), and CC-22 (106-114 ft bls). The fracture network at the plant area is well connected vertically and horizontally. During aquifer testing, drawdown was observed in observation well CC-2, which is more than $370 \mathrm{ft}$ away from the pumped wells.

\section{DisPOSAL AREA}

At the disposal area, five wells (CC-5, CC-9, CC-10, CC-11, and CC-14) were drilled for previous investigations (fig. 35). Construction data for these wells are summarized in table 1. Drilling logs and well-construction diagrams are compiled by $\mathrm{CH} 2 \mathrm{M}$ HILL, Inc. (1995). Four wells (CC-15, CC-16, CC-17, and CC-18) were drilled for this investigation (fig. 35). Geologic logs are given in appendix 2, and wellconstruction diagrams are given in appendix 3.

\section{RESULTS OF BOREHOLE GEOPHYSICAL LOGGING}

Natural-gamma logs were run in wells CC-15, CC-16, CC-17, and CC-18 after completion as monitor wells because they were collapsing as they were being drilled. A natural-gamma log was run in well CC-10 prior to reconstruction as a screened monitor well. Borehole geophysical logs were not run in well CC-5 because it is screened, in well CC-9 because of an obstruction (round piece of metal) at the bottom of the casing, or in wells CC-11 and CC-14 because of the short open interval ( 3 and $4 \mathrm{ft}$, respectively). 


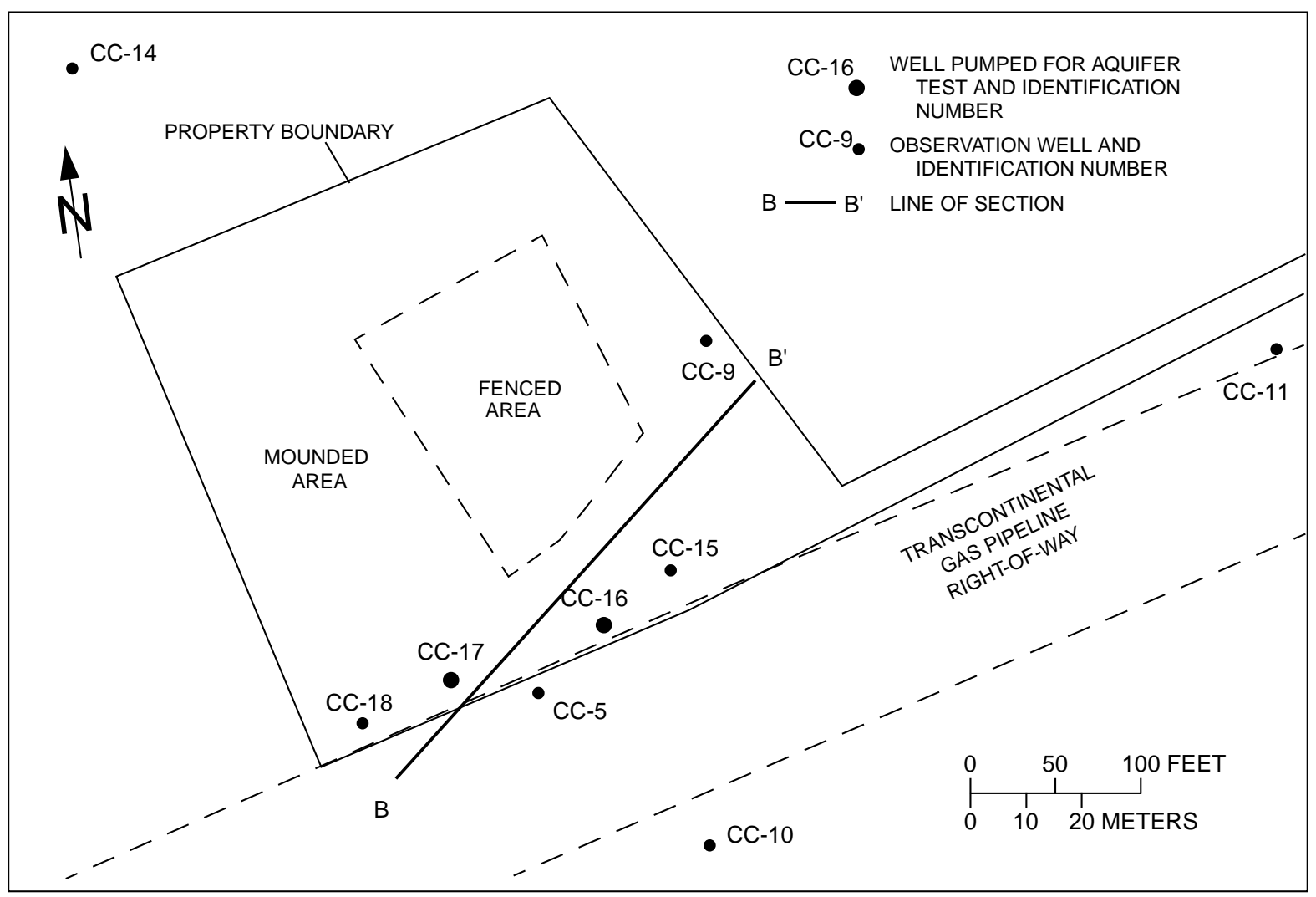

Figure 35. Location of wells at the disposal area, Malvern TCE Site, Chester County, Pennsylvania.

\section{CC-10}

The natural-gamma log from well CC-10 (fig. 36) shows that the well had collapsed to the bottom of the casing, which is set to $124 \mathrm{ft}$ bls. The log shows clay-filled, highly fractured zones at 72-82 and 93-124 ft bls. The drilling log indicates that a $75 \mathrm{gal} / \mathrm{min}$ water-bearing fracture was penetrated at $125 \mathrm{ft}$ bls. After logging, the well was cleaned out to $134.6 \mathrm{ft}$ bls, and a screen was set from 124.6 to $134.6 \mathrm{ft}$ bls.

\section{C-15, CC-16, CC-17, and CC-18}

Wells drilled for this investigation at the disposal area were continually collapsing as they were being drilled. The rock beneath the disposal area is highly fractured and contains clay-filled fractures. Drillers commonly refer to this type of highly fractured rock as "broken rock." Well CC-18 was drilled to $200 \mathrm{ft}$ bls without encountering stable rock. Because the holes would not stay open, they were cased to the bottom prior to setting screens. Therefore, only natural-gamma logs were run.
The natural-gamma logs (fig. 37) show that the thickness of the weathered (clay) zone overlying bedrock ranges from $52 \mathrm{ft}$ (CC-15) to $66 \mathrm{ft}$ bls (CC-16). Three of the wells penetrate the same clay-filled fracture zone at about $100 \mathrm{ft}$ bls-CC-15 at 100$106 \mathrm{ft}$ bls, CC-16 at 104-112 ft bls, and CC-17 at 94$101 \mathrm{ft}$ bls (fig. 38). The land-surface elevation of these wells ranges from 365.57 to $365.93 \mathrm{ft}$ above sea level. Well CC-18 penetrates clay-filled fracture zones at $142-146$ and $162-176 \mathrm{ft}$ bls. The major waterproducing zones were penetrated just above the upper zone and just below the lower zone.

\section{Results OF AQUifer TeSTS}

Wells CC-16 and CC-17 (fig. 35) were selected for aquifer testing on the basis of yield and VOC concentrations. A 24-hour aquifer test was run in each well. 


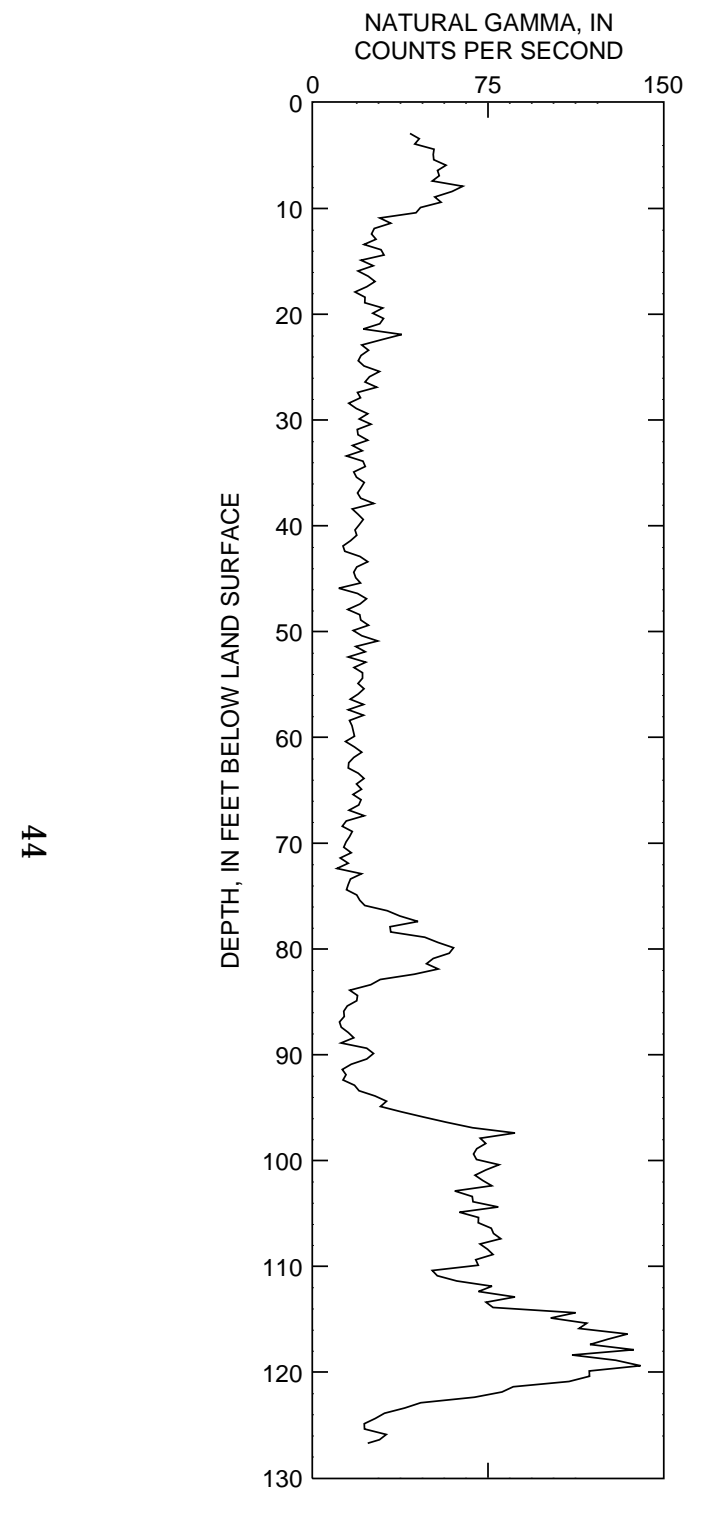

Figure 36. Natural-gamma log for well CC-10, Malvern TCE Site, Chester County, Pennsylvania.
NATURAL GAMMA, IN COUNTS PER SECOND
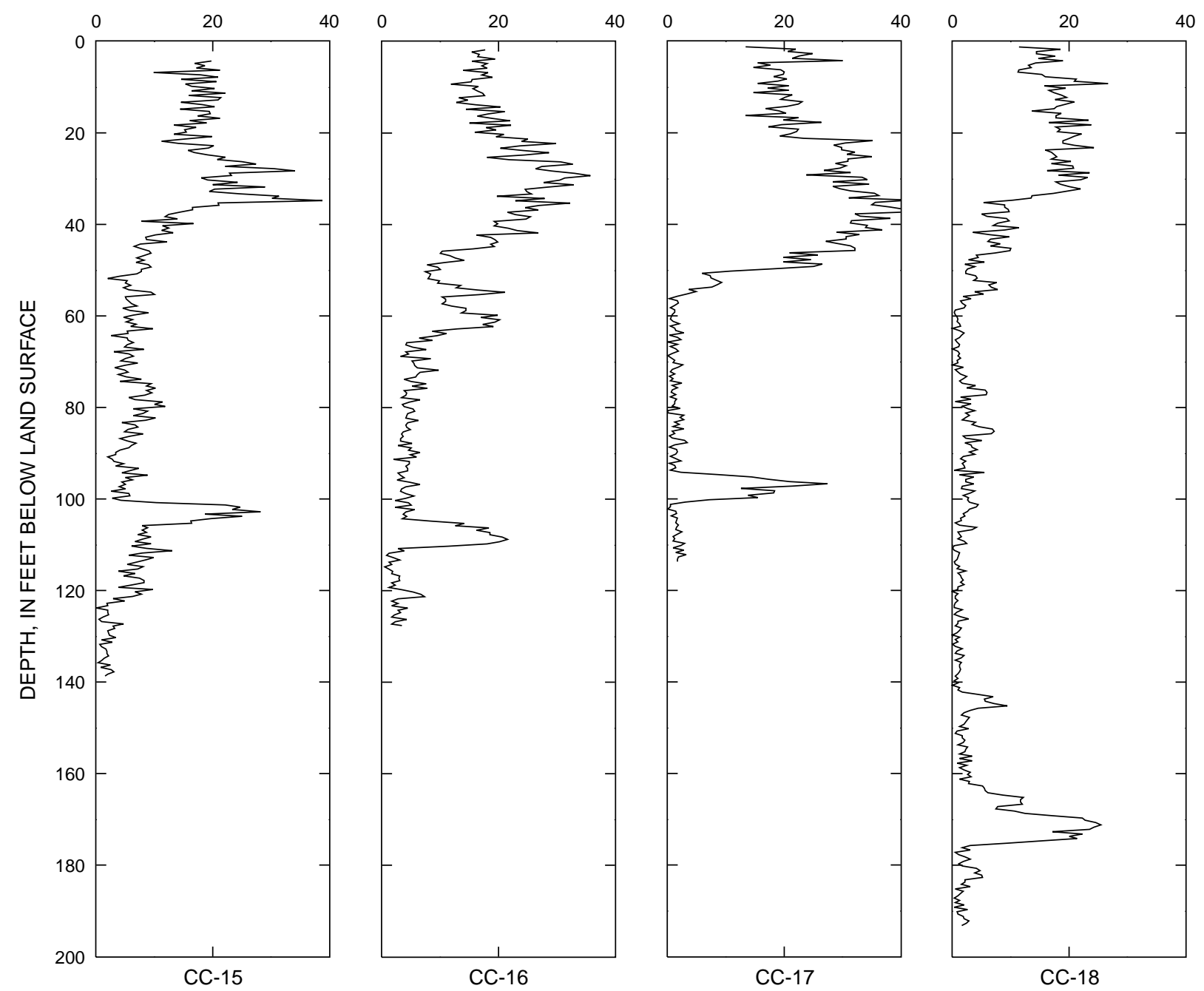

Figure 37. Natural-gamma logs for wells CC-15, CC-16, CC-17, and CC-18, Malvern TCE Site, Chester County, Pennsylvania. 


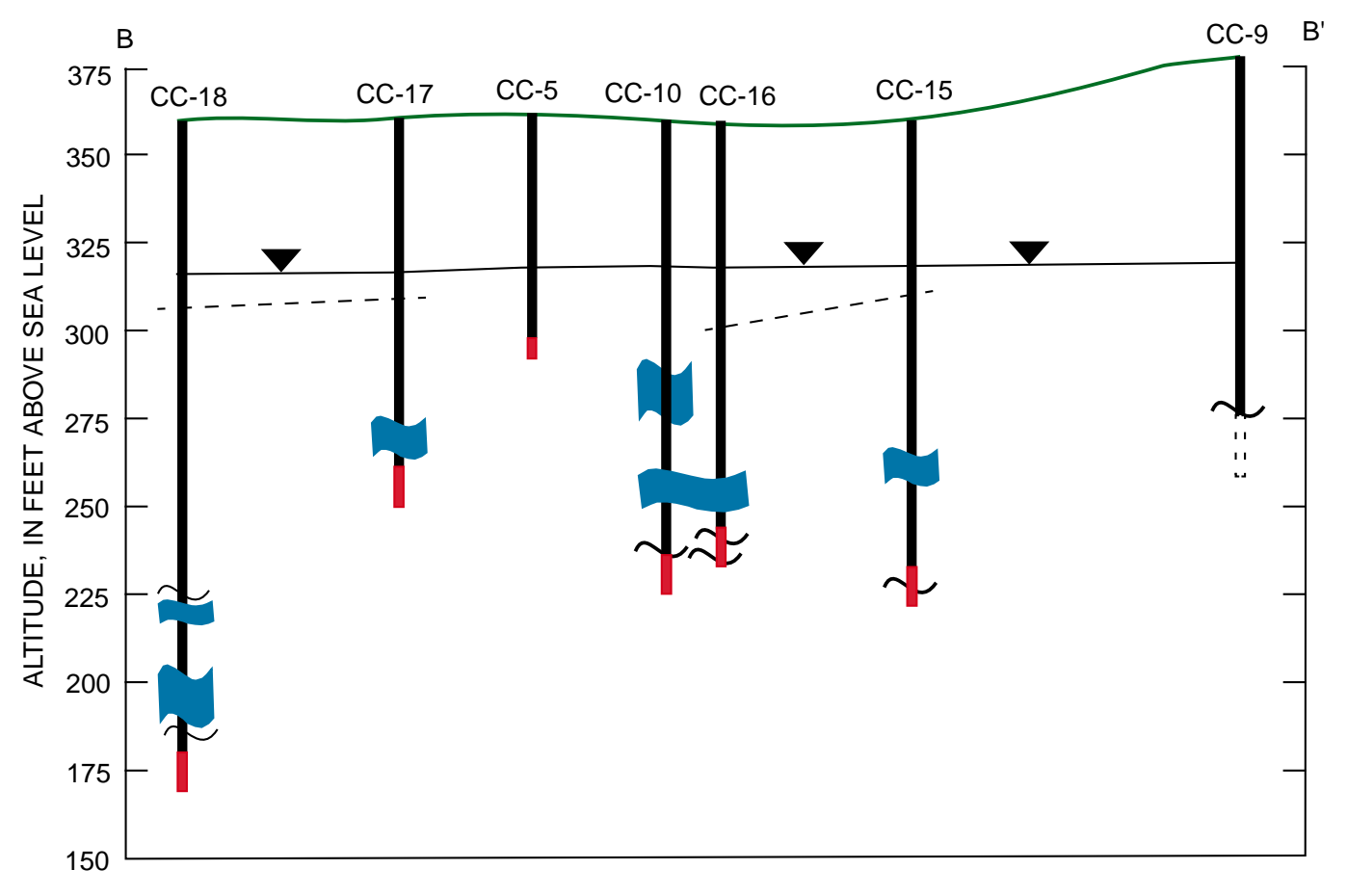

EXPLANATION
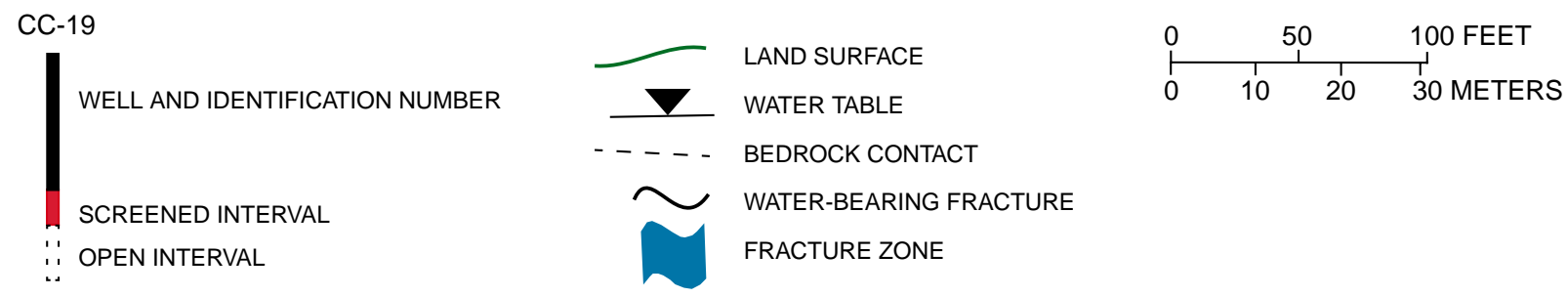

Figure 38. Generalized cross-section of the disposal area, Malvern TCE Site, Chester County, Pennsylvania. Line of section is shown on figure 35.

\section{CC-16}

An aquifer test of well CC-16 was conducted on May 14-15, 1996. Three days prior to the test, $0.8 \mathrm{in}$. of rain fell. No precipitation fell during the test. Prior to and during the test, the water level in well CC-2 was rising (fig. 25). During the test, the water level in well CC-2 rose $0.14 \mathrm{ft}$, and the water level in well CC-14, which is $462 \mathrm{ft}$ northwest of well CC-16, rose $0.09 \mathrm{ft}$. Well CC-16 was pumped for 1,450 minutes (24 hours and 10 minutes) at $39.6 \mathrm{gal} / \mathrm{min}$, the maximum pump capacity. The drawdown was $19.33 \mathrm{ft}$ (fig. 39), and the specific capacity was $2(\mathrm{gal} / \mathrm{min}) / \mathrm{ft}$. Transmissivity was not estimated from data for well CC-16 because the water level decreased to $23.66 \mathrm{ft}$ in 5.5 minutes, stabilized, and then began to rise. This was caused by clay-filled fractures becoming unplugged or partially unplugged and providing additional water to the well.

Drawdown measured in the observation wells ranged from 0.20 to $0.62 \mathrm{ft}$ (table 6). Drawdown curves for observation wells CC-5, CC-9, CC-10, and CC-18 are in appendix 4, figures 29-32. The drawdown data were not corrected for trend. Because of a transducer malfunction, no data were recorded for well CC-15. The water level in the observation 
Table 6. Measured drawdown and estimated transmissivity for the aquifer test of well CC-16, May 14-15, 1996, Malvern TCE Site, Chester County, Pennsylvania

[--, no data]

\begin{tabular}{|c|c|c|c|c|c|c|}
\hline \multirow[b]{2}{*}{$\begin{array}{c}\text { Well- } \\
\text { identification } \\
\text { number }\end{array}$} & \multirow[b]{2}{*}{$\begin{array}{l}\text { Distance from } \\
\text { pumped well } \\
\text { (feet) }\end{array}$} & \multirow[b]{2}{*}{$\begin{array}{l}\text { Maximum } \\
\text { drawdown } \\
\quad \text { (feet) }\end{array}$} & \multicolumn{2}{|c|}{ Drawdown data } & \multicolumn{2}{|c|}{ Recovery data } \\
\hline & & & $\begin{array}{c}\text { Change in } \\
\text { drawdown over } \\
\text { one log cycle } \\
\text { (feet) }\end{array}$ & $\begin{array}{c}\text { Estimated } \\
\text { transmissivity } \\
\text { (feet squared } \\
\text { per day) }\end{array}$ & $\begin{array}{c}\text { Change in } \\
\text { drawdown over } \\
\text { one log cycle } \\
\text { (feet) }\end{array}$ & $\begin{array}{c}\text { Estimated } \\
\text { transmissivity } \\
\text { (feet squared } \\
\text { per day) }\end{array}$ \\
\hline \multicolumn{7}{|l|}{ Pumped well } \\
\hline CC-16 & -- & 19.33 & -- & -- & -- & -- \\
\hline \multicolumn{7}{|c|}{ Observation wells } \\
\hline CC-5 & 58.5 & .23 & 1.03 & 1,360 & 0.03 & 46,600 \\
\hline CC-9 & 177.5 & .26 & 1.27 & 1,100 & .04 & 34,900 \\
\hline CC-10 & 146 & .36 & -- & -- & .06 & 23,300 \\
\hline CC-15 & 51 & .29 & -- & -- & -- & -- \\
\hline $\mathrm{CC}-17$ & 97 & .20 & -- & -- & .04 & 34,900 \\
\hline CC-18 & 156.5 & .62 & .67 & 2,090 & .26 & 5,370 \\
\hline
\end{tabular}

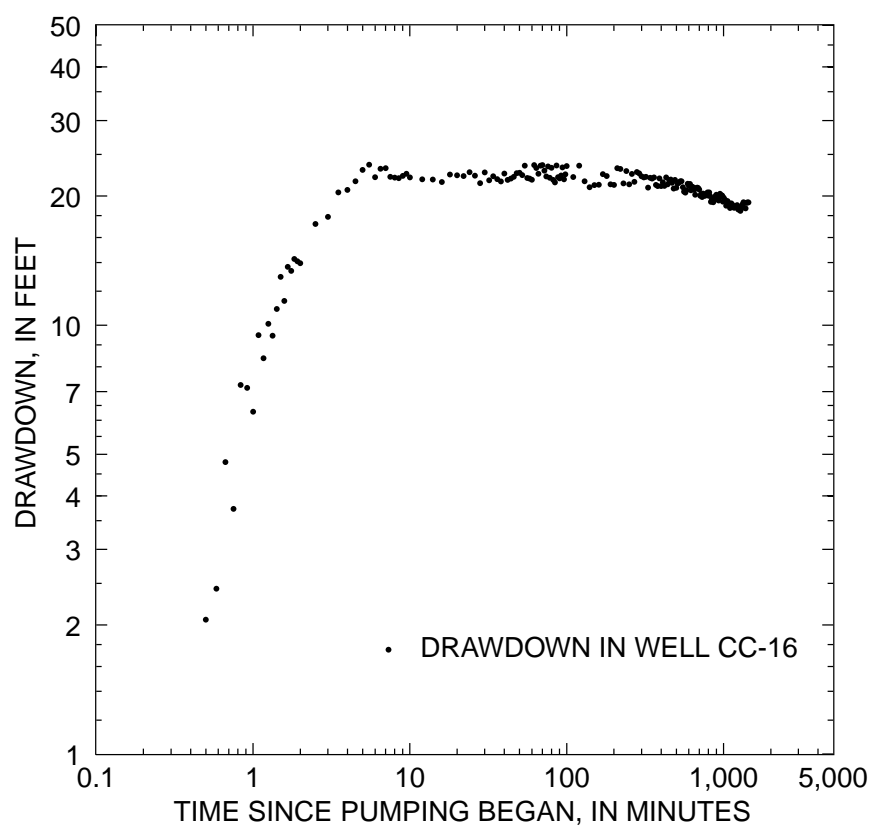

Figure 39. Relation between drawdown in well CC-16 and time for aquifer test of well CC-16, May 14-15, 1996, Malvern TCE Site, Chester County, Pennsylvania. wells began declining about 200-600 minutes into the test (fig. 40). Before that time, water levels were erratic. The water level in well CC-5 sharply rose 10 minutes into the test. The water level in well CC-9 sharply dropped 32 minutes into the test. The water level in well CC-10 began to decline at the start of the test to $1.36 \mathrm{ft}$ bls at 230 minutes. At 240 minutes, the water level sharply rose to $0.26 \mathrm{ft}$ bls and then began declining again. Transmissivity was not estimated from data for well CC-17 because of scatter in the data points (fig. 40). Sensitivity of the transducers ranged from 0.01 to $0.03 \mathrm{ft}$. Transmissivity estimated from the drawdown data measured in wells CC-5, CC-9, and CC-18 ranges from 1,110 to 2,090 $\mathrm{ft}^{2} / \mathrm{d}$ (table 6).

Recovery of water levels was measured for 160 minutes after pumping ceased. Complete recovery of the water level in well CC-16 took 0.8 minutes (fig. 41), and transmissivity could not be estimated. Recovery curves for the observation wells are in appendix 4, figures 33-37. Transmissivity estimated from the recovery data for observation wells ranges from 5,370 to $46,600 \mathrm{ft}^{2} / \mathrm{d}$ (table 5); the median transmissivity is $34,900 \mathrm{ft}^{2} / \mathrm{d}$. 


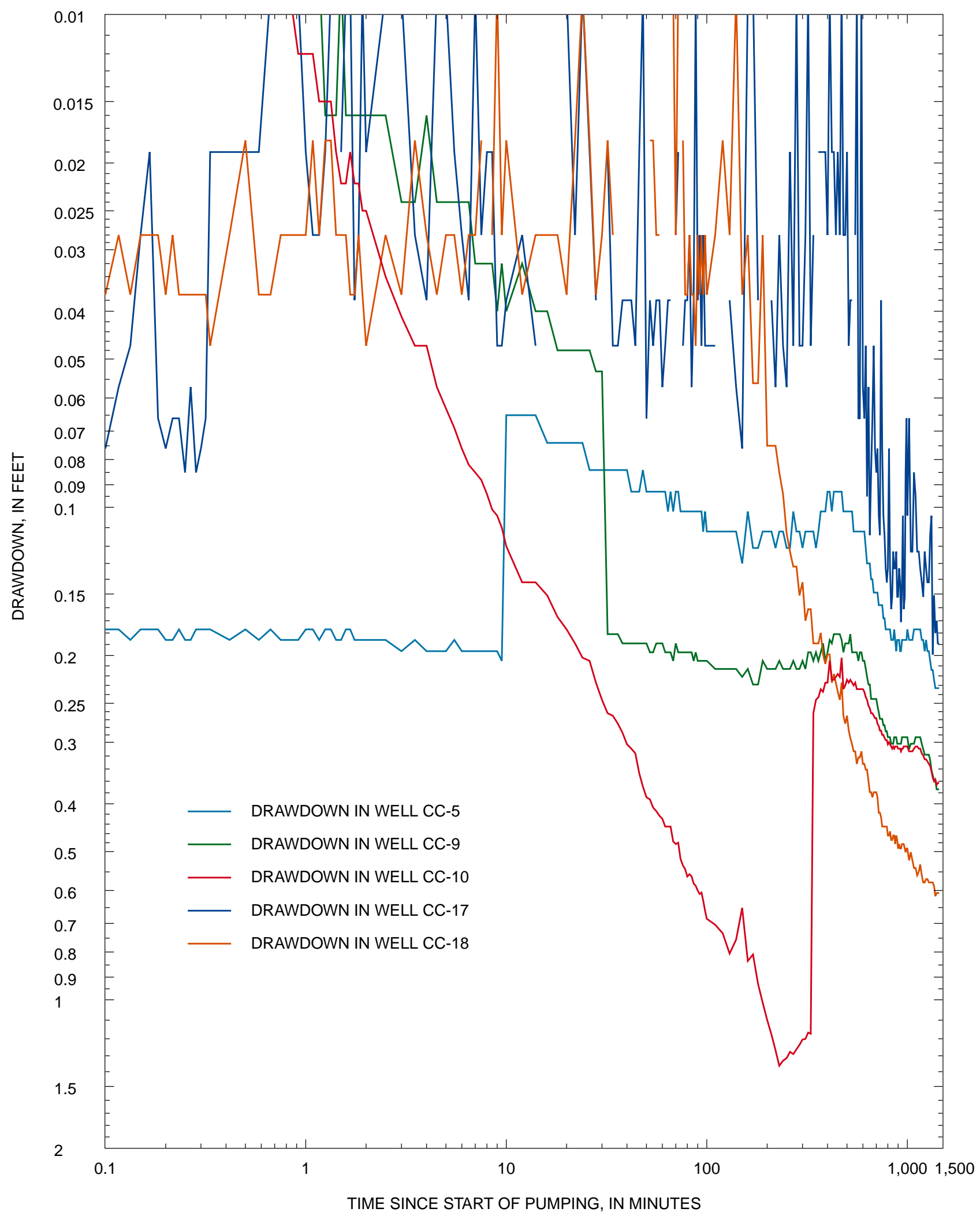

Figure 40. Relation between drawdown in observation wells and time for aquifer test of well CC-16, May 14-15, 1996, Malvern TCE Site, Chester County, Pennsylvania. 


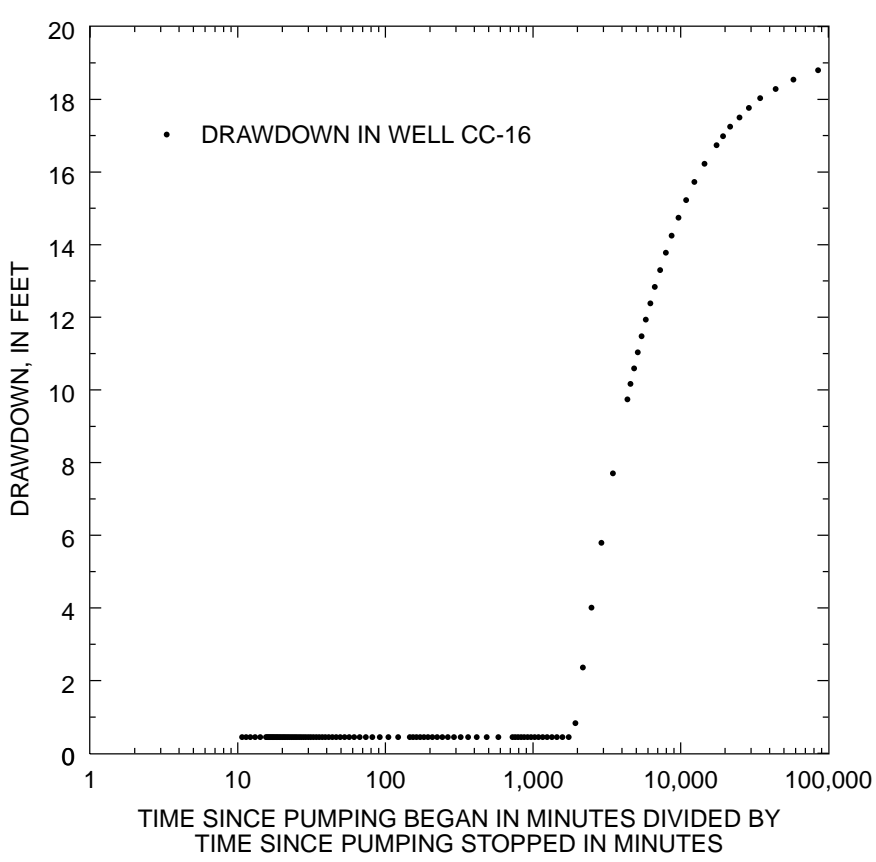

Figure 41. Relation between drawdown in well CC-16 and time for recovery phase of aquifer test of well CC-16, May 15, 1996, Malvern TCE Site, Chester County, Pennsylvania.

\section{CC-17}

An aquifer test of well CC-17 was conducted on May 16-17, 1996. No precipitation fell for 2 days prior to the test. During the test, a light rain (0.41 in. of precipitation) fell. Prior to and during the test, the water level in well CC-2 was rising (fig. 25). During the test, the water level in well CC-2 declined $0.02 \mathrm{ft}$, and the water level in well CC-14, which is $430 \mathrm{ft}$ northwest of well CC-16, declined $0.01 \mathrm{ft}$. Well CC-17 was pumped for 1,450 minutes ( 24 hours and 10 minutes) at $43.2 \mathrm{gal} / \mathrm{min}$, the maximum pump capacity. Transducer data for well CC-17 were unreliable (fig. 42); the drawdown measured in well CC-17 with an electric tape was $0.28 \mathrm{ft}$. The specific capacity was 154 (gal/min)/ft. Transmissivity was not estimated for the pumping phase of this test because of erratic water levels in all wells (fig. 43). Well CC-18 shows over $0.5 \mathrm{ft}$ of water-level rise from recharge. The water-level rise at about 200 minutes in the other observation wells may be recharge.

Drawdown in the observation wells, which began at about 450 minutes, is erratic (fig. 42). The small drawdowns (table 7) indicate that the aquifer was not sufficiently stressed to produce reliable results from the drawdown or recovery data; therefore, transmissivity was estimated using equation 3 with a specific capacity of $154(\mathrm{gal} / \mathrm{min}) / \mathrm{ft}$. Because drawdown was only $0.28 \mathrm{ft}$ in well CC-17, no well loss was assumed. Transmissivity estimated from equation 2 is $56,200 \mathrm{ft}^{2} / \mathrm{d}$.

Recovery of water levels was measured for 62 to 130 minutes after pumping ceased. The recovery of water levels measured in well CC-17 is shown in figure 44. Recovery curves for the observation wells are in appendix 4, figures 38-43.

Table 7. Measured drawdown for aquifer test of well CC-17, May 16-17, 1996, Malvern TCE Site, Chester County, Pennsylvania

\begin{tabular}{lcc}
\hline $\begin{array}{c}\text { Well-identification } \\
\text { number }\end{array}$ & $\begin{array}{c}\text { Distance } \\
\text { from pumped } \\
\text { well (feet) }\end{array}$ & $\begin{array}{c}\text { Drawdown } \\
\text { (feet) }\end{array}$ \\
\hline Pumped well & & 0.28 \\
CC-17 & -- & \\
Observation wells & & .14 \\
CC-5 & 53.5 & .10 \\
CC-9 & 252 & .09 \\
CC-10 & 184 & .10 \\
CC-15 & 146 & .11 \\
CC-16 & 97 & -.30 \\
CC-18 & 60 & \\
\hline
\end{tabular}

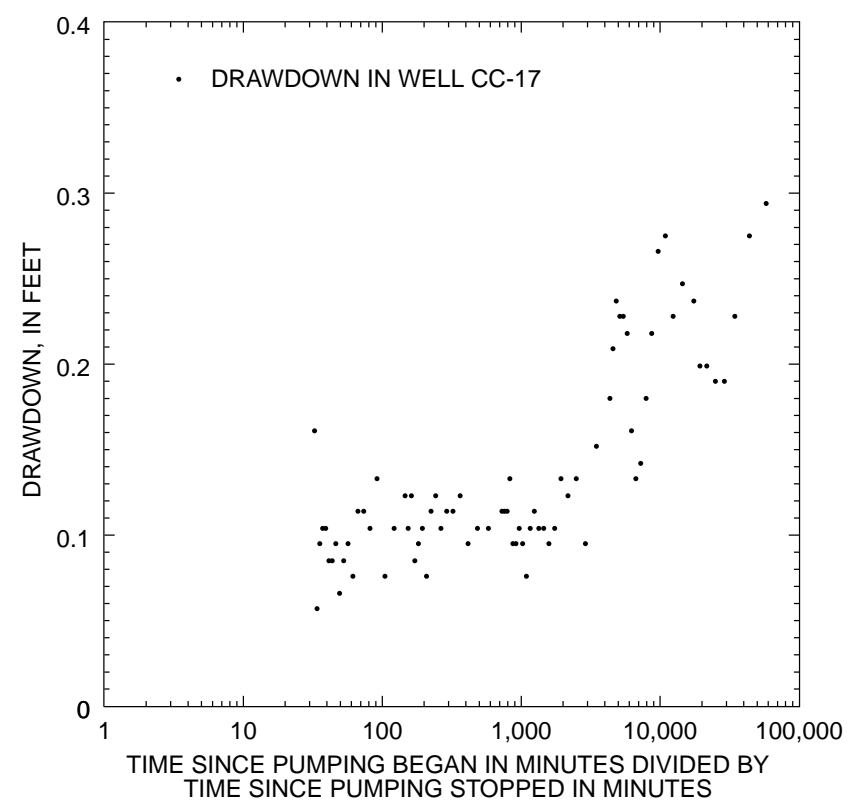

Figure 44. Relation between drawdown in well CC-17 and time for recovery phase of aquifer test of well CC-17, May 17, 1996, Malvern TCE Site, Chester County, Pennsylvania. 


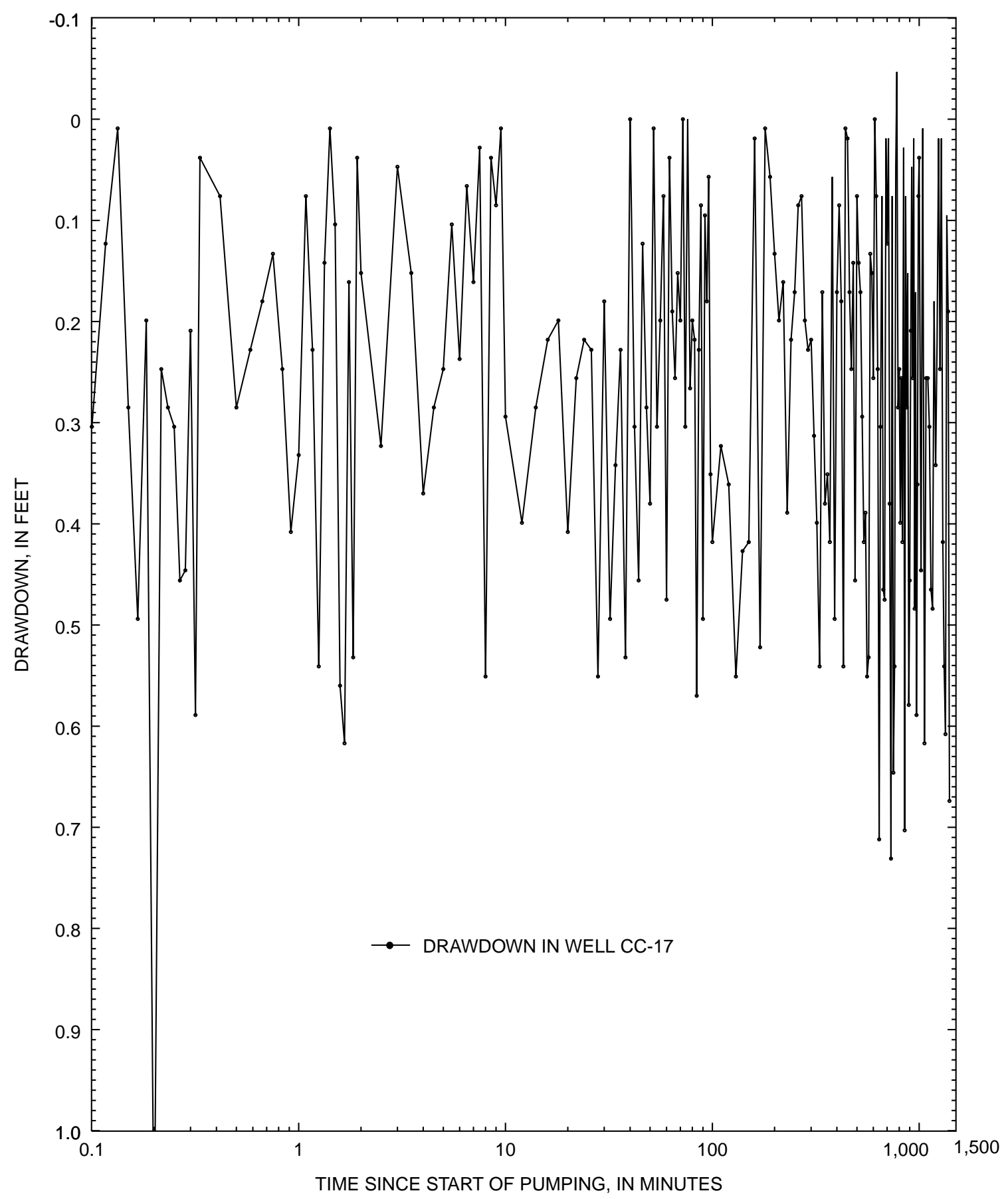

Figure 42. Relation between drawdown in well CC-17 and time for aquifer test of well CC-17, May 16-17, 1996, Malvern TCE Site, Chester County, Pennsylvania. 


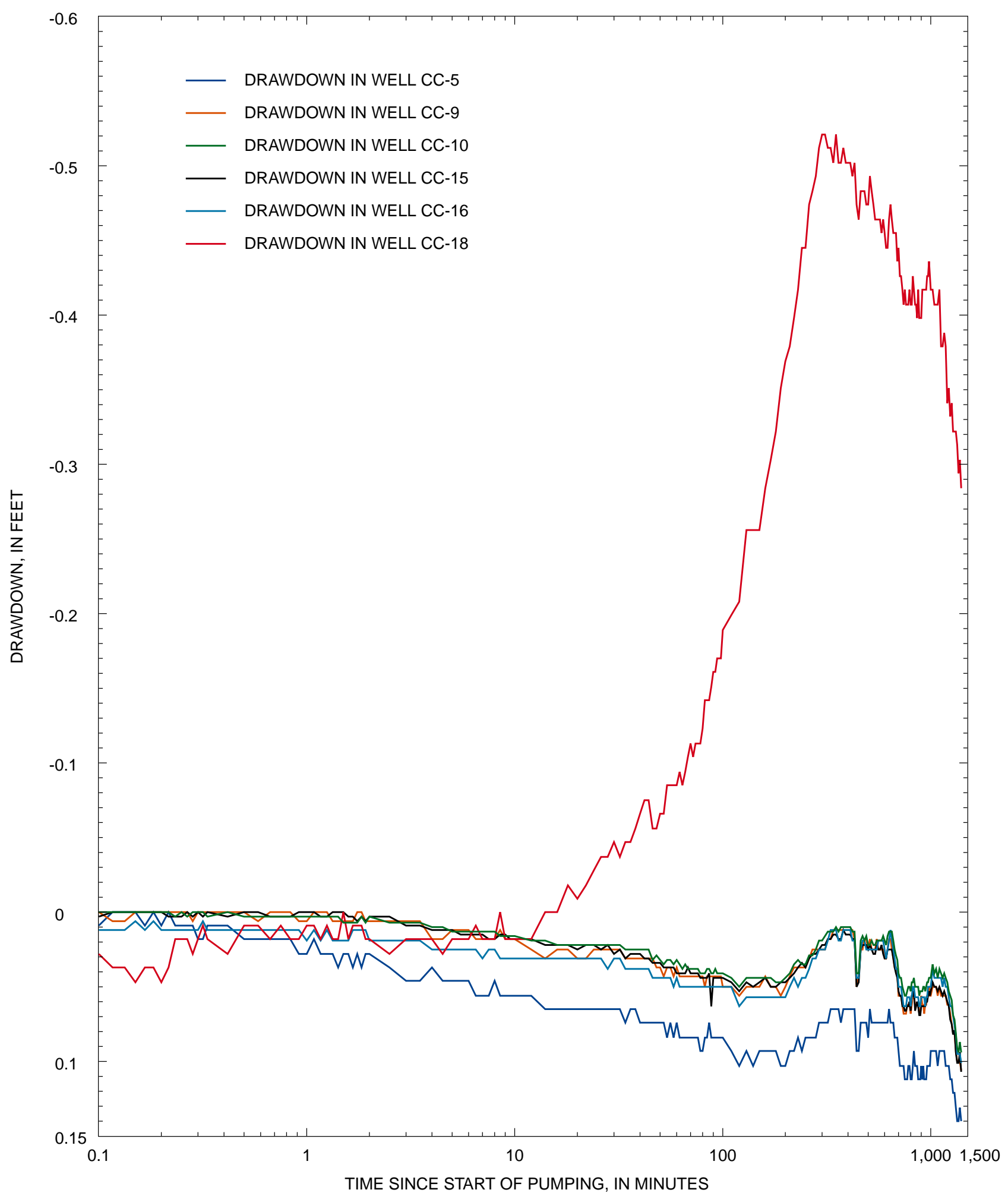

Figure 43. Relation between drawdown in observation wells and time for aquifer test of well CC-17, May 16-17, 1996, Malvern TCE Site, Chester County, Pennsylvania. 


\section{WATER LEVELS}

Water levels were measured continuously in well CC-9. The water levels, plotted as the highest daily water level, show seasonal variations and responses to precipitation similar to wells at the plant area (fig. 32). The range in water-level fluctuation from February 1995 to April 1996 was $25.13 \mathrm{ft}$.

Water levels were measured monthly in all onsite wells from January 1995 to May 1996. The measurements are given in appendix 5 . Wells at the disposal area show a similar magnitude of fluctuation and a similar pattern of seasonal fluctuation to each other and to the wells at the plant area (fig. 45). The range of fluctuation of water levels in the wells near the fenced area is nearly identical, ranging from $24.27 \mathrm{ft}$ in well CC-5 to $24.30 \mathrm{ft}$ in well CC-9. The range of fluctuation measured in upgradient well CC-11 was $24.89 \mathrm{ft}$. The range of fluctuation is nearly identical because the hydraulic gradient is very small, and the water table is nearly flat around the disposal area. When water levels from these wells are plotted as altitude above sea level, the hydrographs plot nearly at the same altitude (fig. 46).

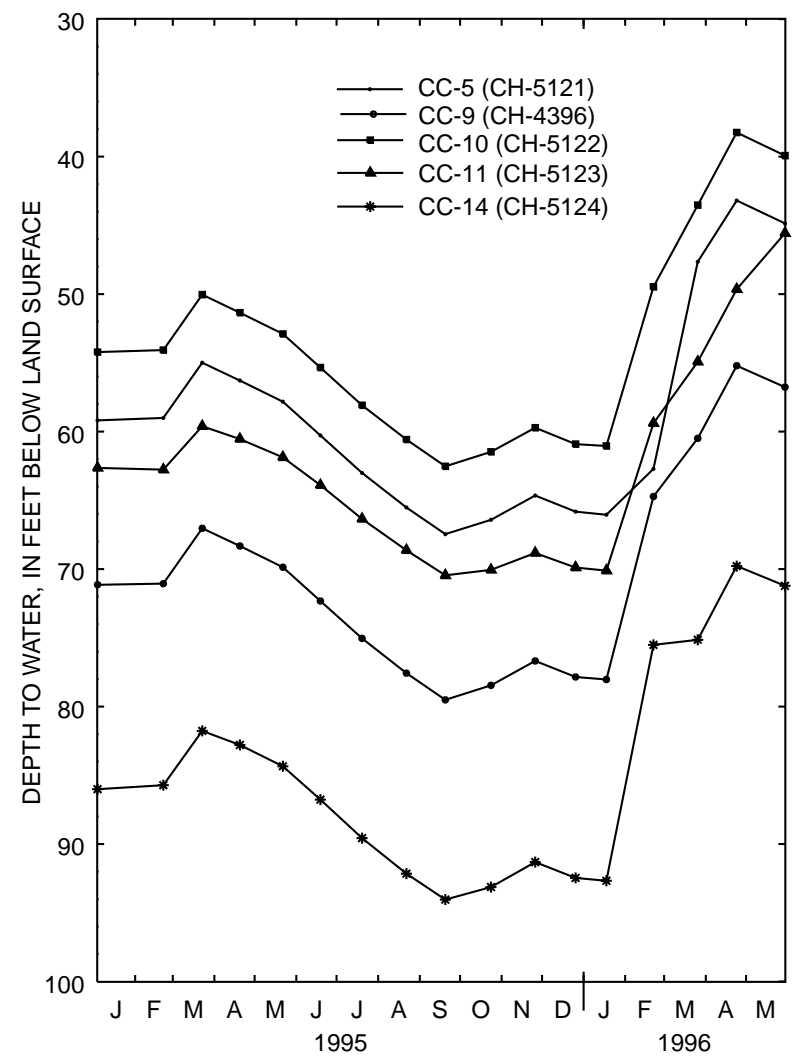

Figure 45. Hydrographs (depth to water) from wells measured monthly at the disposal area, January 1995 to May 1996, Malvern TCE Site, Chester County, Pennsylvania.

\section{DisTRIBUTION OF VOLATILE ORGANIC COMPOUNDS}

Water samples collected from wells at the disposal area in May 1996 (table 5) had maximum concentrations of TCE of $768 \mu \mathrm{g} / \mathrm{L}$ (fig. 47), PCE of $111 \mu \mathrm{g} / \mathrm{L}$ (fig. 48), and TCA of $108 \mu \mathrm{g} / \mathrm{L}$ (fig. 49). The highest concentrations of these constituents were measured in water from well CC-5. The concentrations are lower than concentrations in water samples collected before cleanup of the disposal area was completed in 1984. A water sample collected from well CC-5 on April 21, 1983, contained a concentration of TCE of 9,660 $\mu \mathrm{g} / \mathrm{L}$, PCE of $418 \mu \mathrm{g} / \mathrm{L}$, and TCA of 1,540 $\mu \mathrm{g} / \mathrm{L}$ (CH2M HILL, Inc., 1995). The water samples collected in May 1996 from wells CC-5, CC-10, CC-16, CC-17, and CC-18 contain a higher concentration of dehalogenation product cis-1,2-dichloroethylene than of TCE or PCE; this suggests that the VOC's remaining in the ground water have been degrading since the source was removed.

Water from the disposal area flows toward Valley Creek, approximately $0.3 \mathrm{mi}$ to the south (fig. 9). Water samples collected from off-site wells in

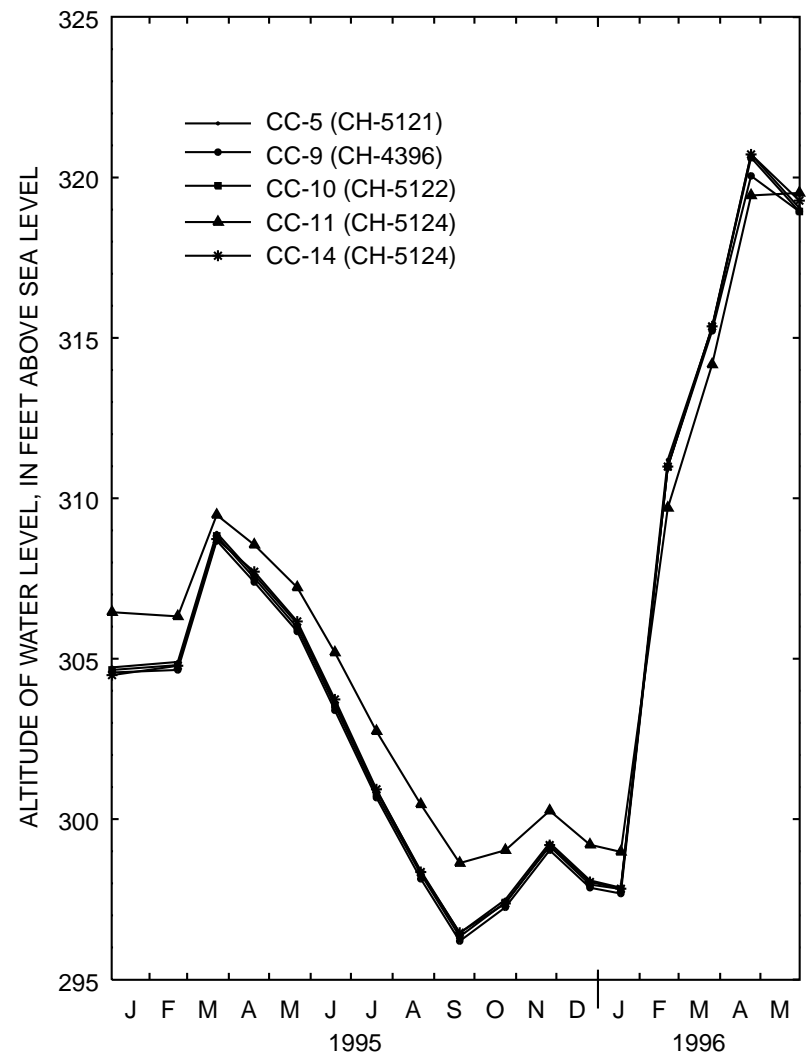

Figure 46. Hydrographs (altitude above sea level) from wells measured monthly at the disposal area, January 1995 to May 1996, Malvern TCE Site, Chester County, Pennsylvania. 


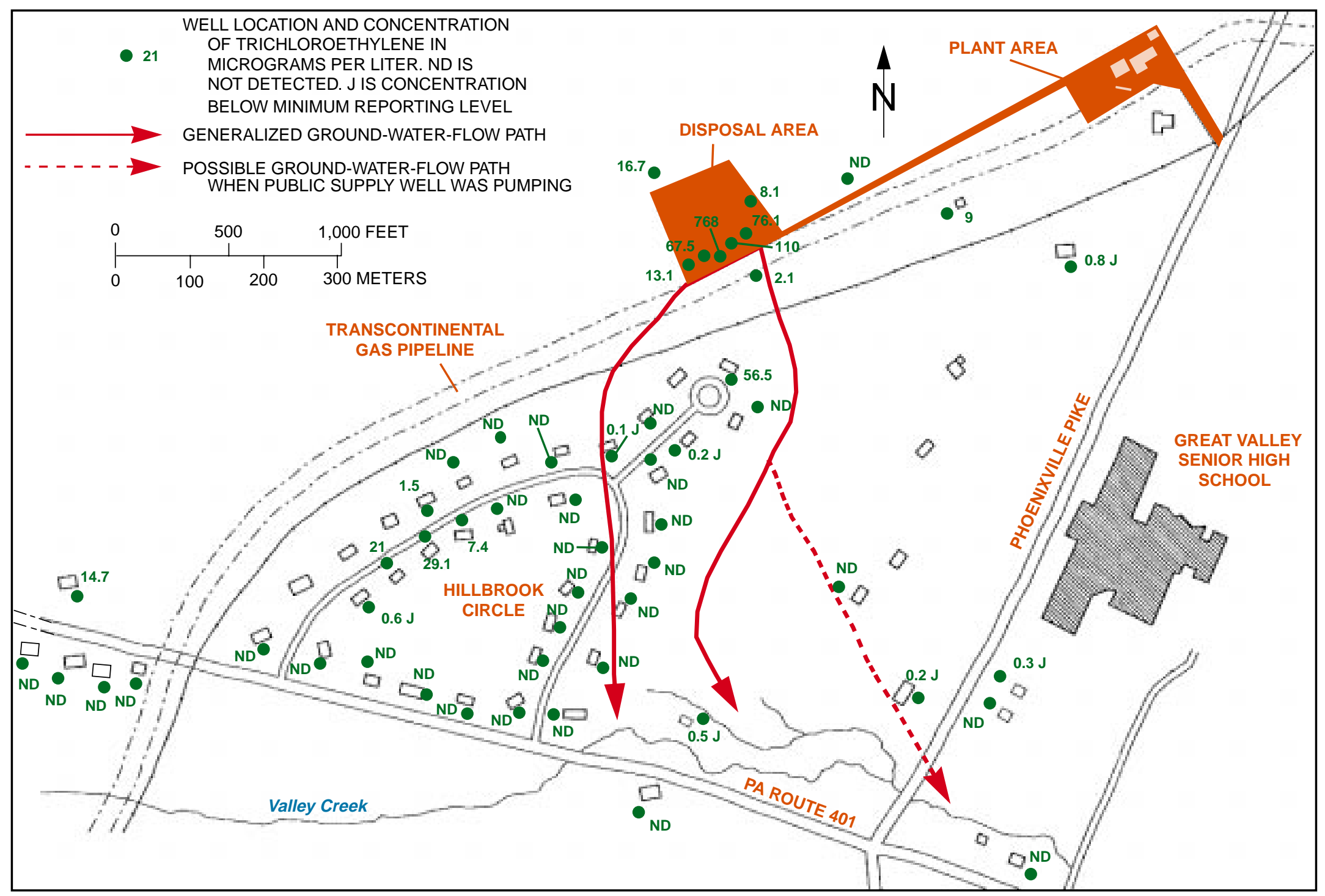

Figure 47. Concentrations of trichloroethylene in water from wells at the disposal area and Hillbrook Circle, 1995-96, Malvern TCE Site, Chester County, Pennsylvania. 


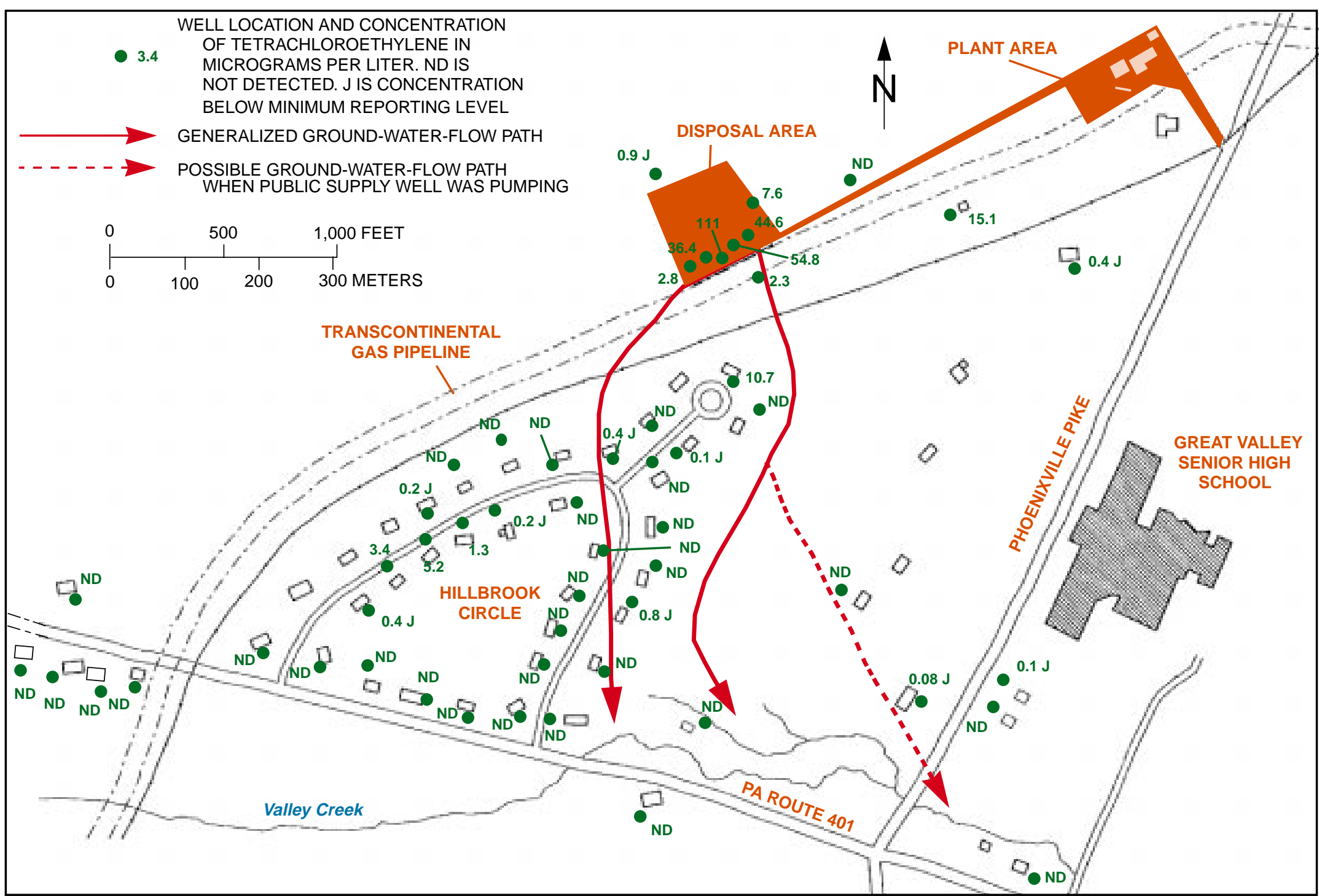

Figure 48. Concentrations of tetrachloroethylene in water from wells at the disposal area and Hillbrook Circle, 1995-96, Malvern TCE Site, Chester County, Pennsylvania. 


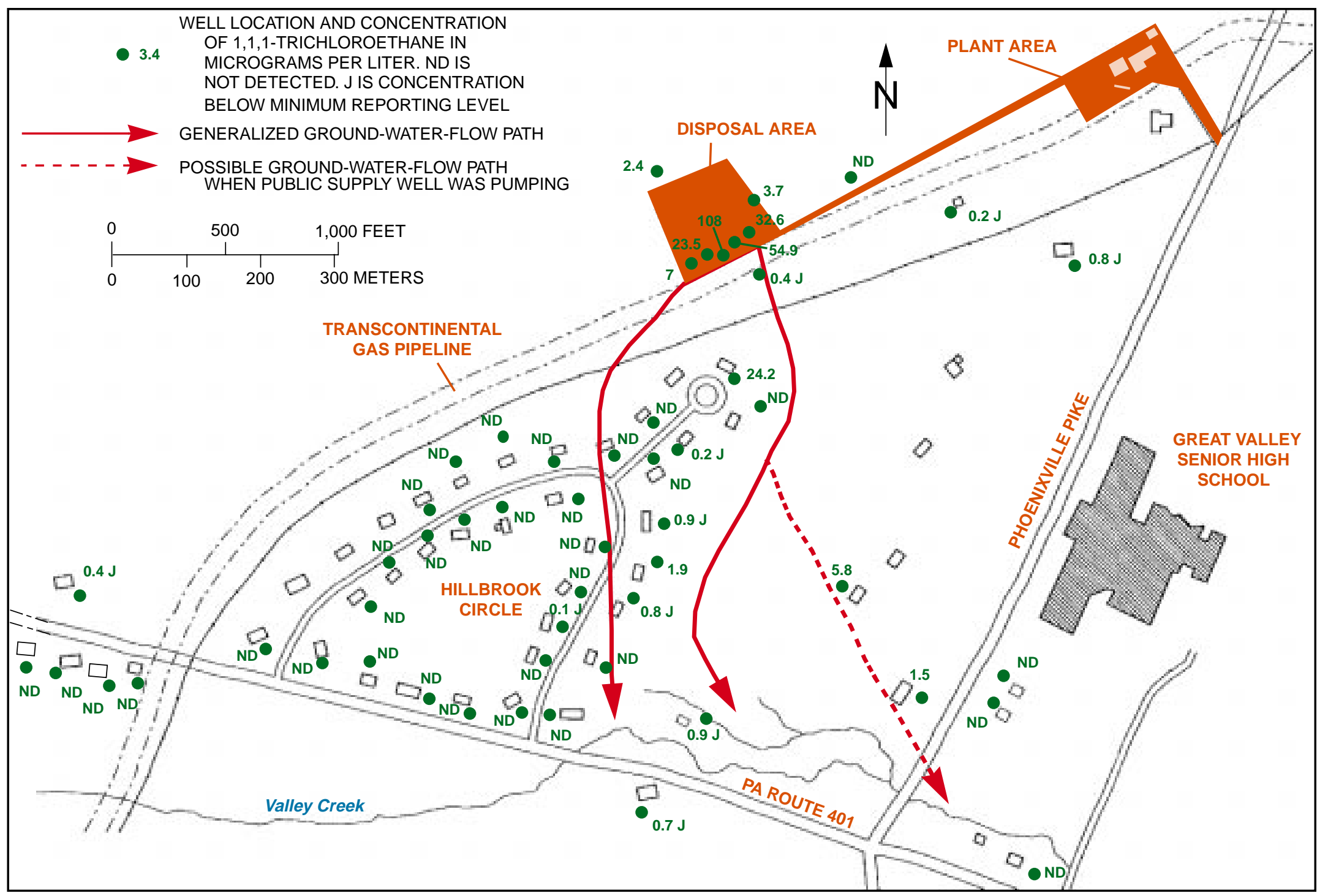

Figure 49. Concentrations of 1,1,1-trichloroethane in water from wells at the disposal area and Hillbrook Circle, 1995-96, Malvern TCE Site, Chester County, Pennsylvania. 
Table 8. Results of chemical analyses for selected volatile organic compounds detected in water samples from off-site wells, 1995, Malvern TCE Site, Chester County, Pennsylvania

[Data provided by the L.R. Dietz (U.S. Environmental Protection Agency, written commun., 1996); concentrations in micrograms per liter; C, concentration reported from diluted sample; J, estimated concentration; ND, compound not detected, minimum detection limit not known]

\begin{tabular}{|c|c|c|c|c|c|c|}
\hline $\begin{array}{c}\text { Off-site well- } \\
\text { identification } \\
\text { number }\end{array}$ & $\begin{array}{c}\text { Date } \\
\text { sampled }\end{array}$ & $\begin{array}{l}\text { 1,1-Dichloro- } \\
\text { ethene }\end{array}$ & $\begin{array}{c}\text { cis-1,2-Dichloro- } \\
\text { ethylene }\end{array}$ & $\begin{array}{l}\text { Tetrachloro- } \\
\text { ethylene }\end{array}$ & $\begin{array}{c}\text { 1,1,1-Trichloro- } \\
\text { ethane }\end{array}$ & $\begin{array}{l}\text { Trichloro- } \\
\text { ethylene }\end{array}$ \\
\hline DW-6 & $08 / 28 / 95$ & ND & 14.6 & 5.2 & ND & $29.1 \mathrm{C}$ \\
\hline DW-7 & $12 / 11 / 95$ & ND & ND & $.4 \mathrm{~J}$ & ND & $.6 \mathrm{~J}$ \\
\hline DW-12 & $06 / 12 / 95$ & ND & ND & ND & $0.7 \mathrm{~J}$ & ND \\
\hline DW-15 & $09 / 05 / 95$ & $0.5 \mathrm{~J}$ & ND & $.08 \mathrm{~J}$ & 1.5 & $.2 \mathrm{~J}$ \\
\hline DW-16 & 08/29/95 & 1.4 & ND & ND & 5.8 & ND \\
\hline DW-23 & 08/29/95 & $.1 \mathrm{~J}$ & 1.3 & $.4 \mathrm{~J}$ & $.8 \mathrm{~J}$ & $.8 \mathrm{~J}$ \\
\hline DW-36 & 08/29/95 & 7.2 & $20.3 \mathrm{C}$ & 10.7 & $24.2 \mathrm{C}$ & $56.5 \mathrm{C}$ \\
\hline DW-42 & $12 / 11 / 95$ & ND & ND & $.1 \mathrm{~J}$ & $.2 \mathrm{~J}$ & $.2 \mathrm{~J}$ \\
\hline DW-44 & 08/29/95 & ND & ND & $.4 \mathrm{~J}$ & ND & $.1 \mathrm{~J}$ \\
\hline DW-45 & 06/09/95 & ND & ND & ND & $.9 \mathrm{~J}$ & ND \\
\hline DW-46 & $06 / 12 / 95$ & 1.1 & ND & ND & 1.9 & ND \\
\hline DW-47 & $06 / 12 / 95$ & ND & ND & $.8 \mathrm{~J}$ & ND & ND \\
\hline DW-50 & 08/28/95 & ND & ND & ND & $.1 \mathrm{~J}$ & ND \\
\hline DW-54 & $12 / 12 / 95$ & ND & ND & $.2 \mathrm{~J}$ & ND & ND \\
\hline DW-55 & $09 / 05 / 95$ & ND & 2.8 & 1.3 & ND & 7.4 \\
\hline DW-56 & $08 / 28 / 95$ & ND & $.7 \mathrm{~J}$ & $.2 \mathrm{~J}$ & ND & 1.5 \\
\hline DW-57 & 08/29/95 & ND & 11 & 3.4 & ND & $21 \mathrm{~J}$ \\
\hline DW-65 & 08/29/95 & ND & ND & 15.1 & $.2 \mathrm{~J}$ & 9 \\
\hline DW-66 & $12 / 11 / 95$ & ND & ND & $.1 \mathrm{~J}$ & ND & $.3 \mathrm{~J}$ \\
\hline DW-67 & $08 / 28 / 95$ & $.09 \mathrm{~J}$ & $.5 \mathrm{~J}$ & ND & $.4 \mathrm{~J}$ & 14.7 \\
\hline DW-100 & $06 / 12 / 95$ & ND & ND & ND & $.9 \mathrm{~J}$ & $.5 \mathrm{~J}$ \\
\hline
\end{tabular}

1995 (table 8) had maximum concentrations of TCE of $56.5 \mu \mathrm{g} / \mathrm{L}$, PCE of $10.7 \mu \mathrm{g} / \mathrm{L}$, and TCA of $24.2 \mu \mathrm{g} / \mathrm{L}$ (figs. 47-49). Concentrations of selected detected compounds are given in table 8; the complete analyses are given in appendix 6 , table 3 . A comparison of data from 1995 (appendix 6, table 3) with data from 1981-84 (CH2M HILL, Inc., 1995) shows that concentrations of TCE, PCE, and TCA in water from most off-site wells have decreased and that water from fewer wells contains detectable concentrations of those compounds (fig. 50). The decrease in concentrations and number of wells affected is most likely caused by cleanup of the disposal area.

\section{HydRogeOLOGIC FrameWORK}

The disposal area is underlain by the Ledger Dolomite. The dolomite at the disposal area is more fractured than the dolomite at the plant area, which is underlain by the Elbrook Formation. Many of the fractures are filled or partially filled with clay. The mean thickness of the weathered (clay) zone overlying bedrock determined from natural-gamma logs is $58 \mathrm{ft}$, which is similar to that of the plant area
$(55 \mathrm{ft})$. Because of the highly fractured nature of the rocks and the presence of numerous clay seams, drilling was very difficult, and none of the wells drilled for this study would stay open. The mean depth to water measured on May 30, 1996, was $70.32 \mathrm{ft}$.

The dolomite at the disposal area yields more water to wells than the dolomite at the plant area. Yields of eight wells at the disposal area range from 15 to more than $200 \mathrm{gal} / \mathrm{min}$, and the median yield is greater than $100 \mathrm{gal} / \mathrm{min}$. Specific capacities for wells at the disposal area range from 2 to $280(\mathrm{gal} / \mathrm{min}) / \mathrm{ft}$. Transmissivity estimated from aquifer-test recovery data for well CC- 16 is $34,900 \mathrm{ft}^{2} / \mathrm{d}$. Transmissivity estimated from aquifer-test specific-capacity data for well CC- 17 is $56,200 \mathrm{ft}^{2} / \mathrm{d}$.

Wells CC-15, CC-16, and CC-17 penetrate the same clay-filled fracture zone at about $100 \mathrm{ft}$ bls. Well CC-18 penetrates clay-filled fracture zones at 142-146 and $162-176 \mathrm{ft}$ bls. The aquifer test data show that the deeper fracture zones penetrated by well CC-18 are hydraulically connected to the shallower fracture zones penetrated by the other three wells. 


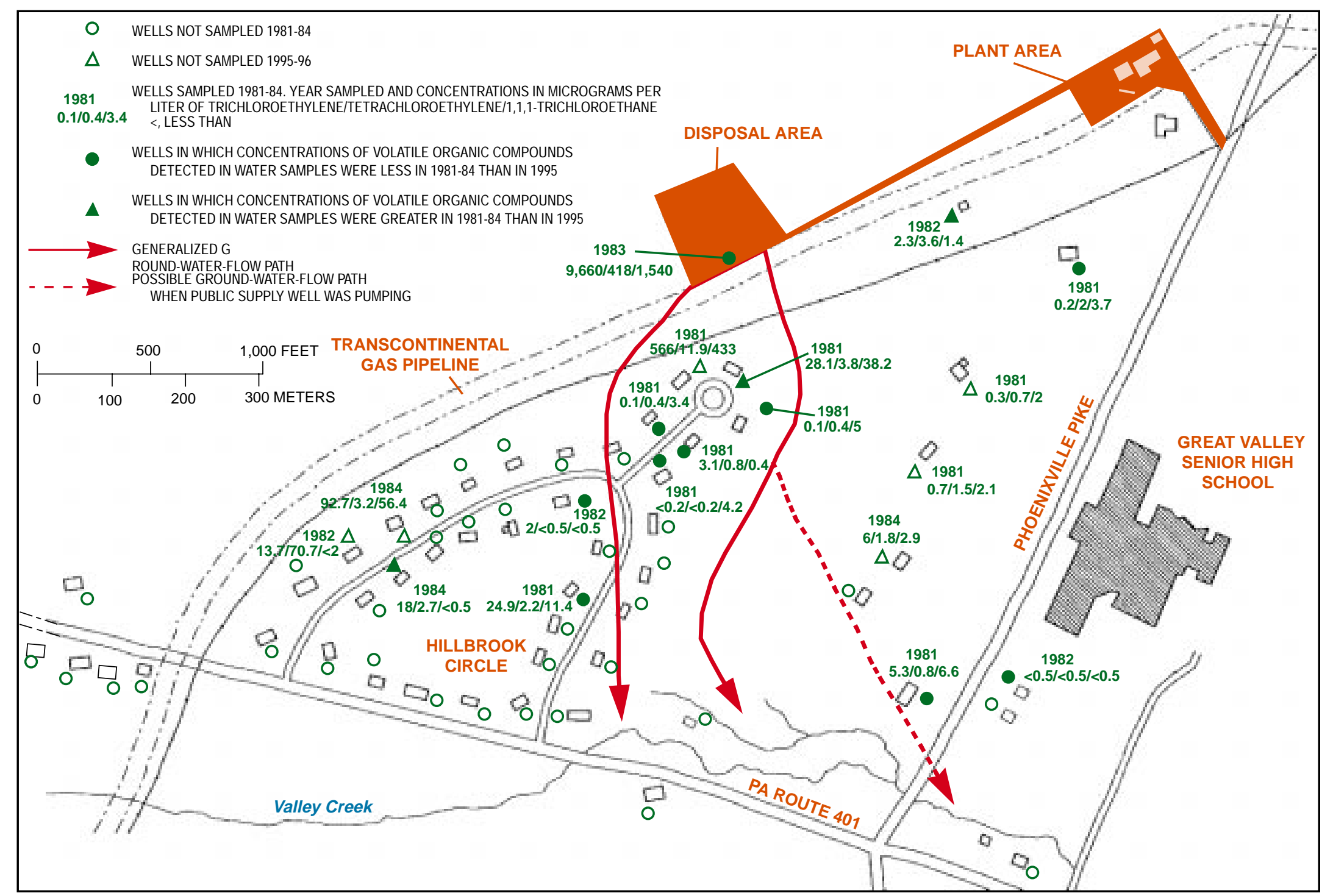

Figure 50. Wells in which volatile organic compounds were detected in water samples, disposal area and Hillbrook Circle, 1981-84, Malvern TCE Site, Chester County, Pennsylvania. 


\section{CAPTURE ZONES}

A capture-zone analysis was used to determine the extent of the capture zone formed by pumping selected wells installed by the USGS. The capture zone and the cone of depression caused by pumping do not coincide. The cone of depression formed by pumping a well describes the area of the aquifer where water levels have been lowered as a result of pumping. The capture zone is a ground-water divide within the cone of depression that describes the area where ground water is transported to the pumped well as a result of pumping.

\section{DISPOSAL OF WATER}

Although an evaluation of disposal methods for pumped and treated water is not an objective of this study, the topic is of sufficient importance to discuss briefly. At the Malvern TCE Site, four options are available for disposal of treated water: (1) discharge to Valley Creek, (2) discharge to the local sewer system, (3) reinjection, and (4) spray irrigation. Valley Creek has been designated as an exceptional value stream by PaDEP, and discharges to the stream are not allowed under this designation. The local sewer system is at its maximum capacity and cannot accept additional flow (J.D. Reimenschneider, East Whiteland Township, oral commun., 1995). Reinjection of treated water is a possibility, but a study may be needed to determine the proper location of injection wells in an area that is not prone to sinkhole development and where a fracture or fracture system would not directly connect the pumping and injection wells. Spray irrigation is also a possibility, but a study may be needed to determine the proper location and acreage requirements for a spray system.

\section{$\underline{\text { Plant Area }}$}

Two capture-zone analyses were done for the plant area, one with well CC-19 pumping and one with wells CC-19 and CC-21 pumping. Median transmissivities estimated for the plant area were $528 \mathrm{ft}^{2} / \mathrm{d}$ (drawdown data) and $839 \mathrm{ft}^{2} / \mathrm{d}$ (recovery data) for the aquifer test of well CC-19 (table 3) and $566 \mathrm{ft}^{2} / \mathrm{d}$ (drawdown data) and $595 \mathrm{ft}^{2} / \mathrm{d}$ (recovery data) for the aquifer test of well CC-21 (table 4). Each capture-zone analysis was run using the highest $\left(839 \mathrm{ft}^{2} / \mathrm{d}\right)$ and lowest $\left(528 \mathrm{ft}^{2} / \mathrm{d}\right)$ transmissivity.

For well CC-19, the available drawdown $(67.45 \mathrm{ft})$ was calculated by subtracting the depth to water $(72.55 \mathrm{ft})$ measured on May 21, 1996, from the depth of the top of the well screen $(140 \mathrm{ft})$. One-half of the available drawdown was multiplied by the specific capacity $[0.59(\mathrm{gal} / \mathrm{min}) / \mathrm{ft}]$ to give a pumping rate of $20 \mathrm{gal} / \mathrm{min}$. For well CC-21, the available drawdown $(22.91 \mathrm{ft})$ was calculated by subtracting the depth to water $(76.09 \mathrm{ft})$ measured on May 23, 1996, from the depth of the top of the well screen (99 ft). One-half of the available drawdown was multiplied by the specific capacity $[0.97(\mathrm{gal} / \mathrm{min}) / \mathrm{ft}]$ to give a pumping rate of $11 \mathrm{gal} / \mathrm{min}$. The hydraulic gradient $(0.015)$ was calculated using water levels at the plant area measured on May 20, 1996, before the start of the plant area aquifer tests.

Pumping wells CC-19 and CC-21 together would form a combined capture zone ranging from approximately $393 \mathrm{ft}$ wide (transmissivity of $839 \mathrm{ft}^{2} / \mathrm{d}$ ) to approximately $630 \mathrm{ft}$ wide (transmissivity of $528 \mathrm{ft}^{2} / \mathrm{d}$ ) at a distance $500 \mathrm{ft}$ upgradient from the center of the pumping wells (fig. 51). Pumping only well CC-19 would form a capture zone ranging from approximately $262 \mathrm{ft}$ wide (transmissivity of $839 \mathrm{ft}^{2} / \mathrm{d}$ ) to approximately $402 \mathrm{ft}$ wide (transmissivity of $528 \mathrm{ft}^{2} / \mathrm{d}$ ) at a distance $500 \mathrm{ft}$ upgradient from well CC-19 (fig. 52). Pumping well CC-19 at a rate of $20 \mathrm{gal} / \mathrm{min}$ would be sufficient to capture all ground-water flow from the plant area.

Although water from wells on the plant site contains higher concentrations of VOC's than water from well CC-19, the yield of the wells on the plant site is too low for recovery. If a DNAPL is present at the plant area, it will slowly partition from the pure phase to the dissolved phase over time. Large fractures and solution openings penetrated by wells drilled at the plant site indicate the presence of subsurface voids where a DNAPL could collect and conduits through which it could move. Pumping wells at the plant could potentially mobilize DNAPL. However, pumping wells CC-19 and CC-20 could also mobilize DNAPL. Pumping well CC-19 would induce the flow of water with higher concentrations of VOC's to the well with time. After 23 hours of pumping well CC-19, the concentration of TCE increased from 120 to $1,110 \mu \mathrm{g} / \mathrm{L}, \mathrm{PCE}$ from 58 to $230 \mu \mathrm{g} / \mathrm{L}$, TCA from 33 to $270 \mu \mathrm{g} / \mathrm{L}$, and 1,2-dichloroethylene from 5 to $86 \mu \mathrm{g} / \mathrm{L}$ (appendix 6, table 2). Pumping well CC-19, which is screened from 140-180 ft bls could induce the flow of VOC's lower into the aquifer. Pumping well CC-19 at a rate of $20 \mathrm{gal} / \mathrm{min}$ would not affect water levels in nearby domestic wells. 


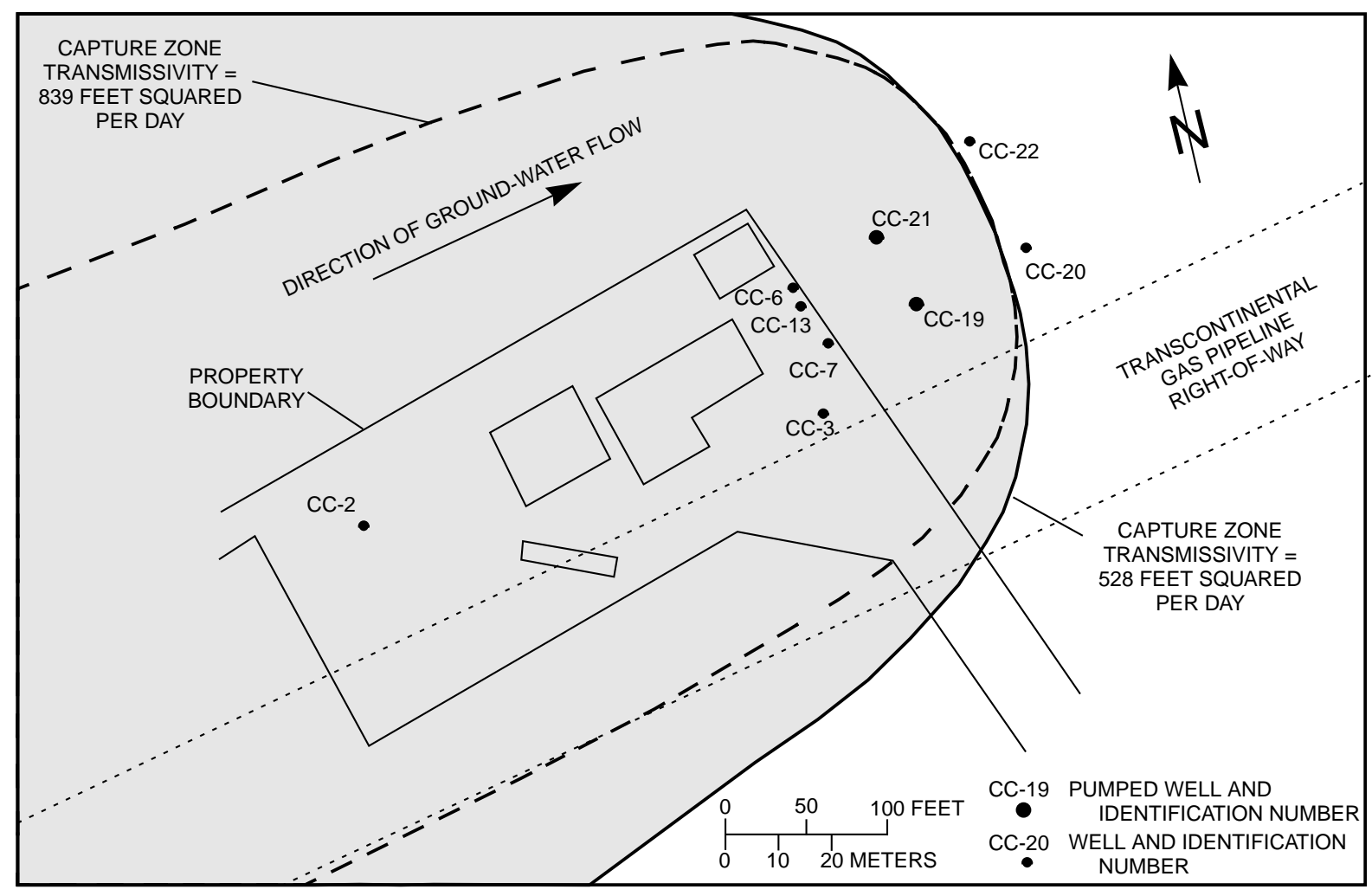

Figure 51. Capture zone formed by pumping wells CC-19 and CC-21 at the plant area, Malvern TCE Site, Chester County, Pennsylvania.

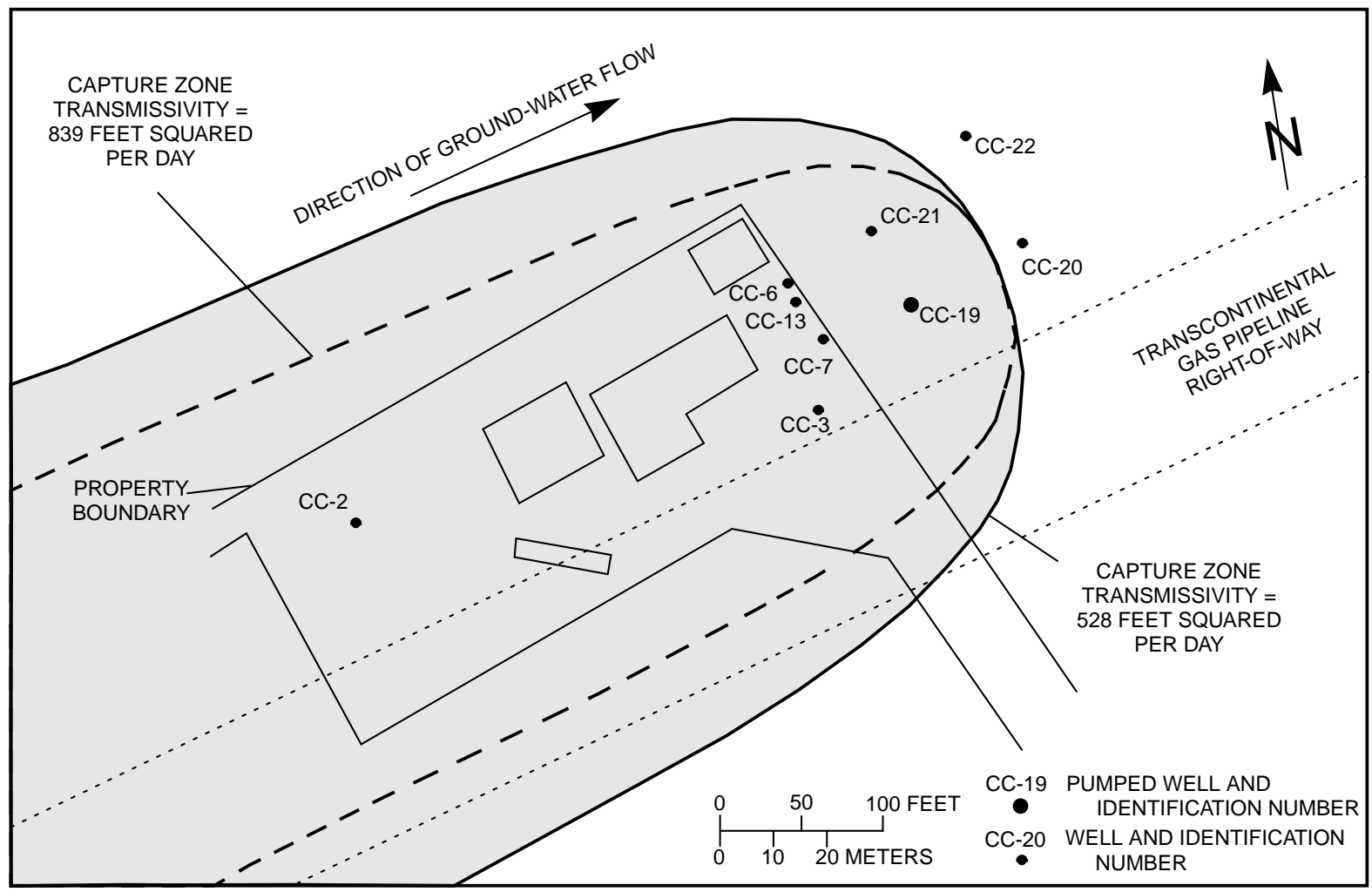

Figure 52. Capture zone formed by pumping well CC-19 at the plant area, Malvern TCE Site, Chester County, Pennsylvania. 


\section{Disposal AREA}

Two capture-zone analyses were done for the disposal area, one with wells CC-16 and CC-17 pumping and one with wells CC-16, CC-17, and CC-18 pumping. Median transmissivities estimated for the disposal area were $34,900 \mathrm{ft}^{2} / \mathrm{d}$ (recovery data) for the aquifer test of well CC-16 (table 6) and $56,200 \mathrm{ft}^{2} / \mathrm{d}$ for the aquifer test of well CC-17. Each capture-zone analysis was run using both transmissivity values.

For well CC-16, the available drawdown $(72.21 \mathrm{ft})$ was calculated by subtracting the depth to water (46.79 ft) measured on May 13, 1996, from the depth of the top of the well screen $(119 \mathrm{ft})$. One-half of the available drawdown was multiplied by the specific capacity [2 $(\mathrm{gal} / \mathrm{min}) / \mathrm{ft}$ ] to give a pumping rate of $72 \mathrm{gal} / \mathrm{min}$. For well CC-17, the available drawdown $(56.41 \mathrm{ft})$ was calculated by subtracting the depth to water $(48.59 \mathrm{ft})$ measured on May 13, 1996, from the depth of the top of the well screen $(105 \mathrm{ft})$. One-half of the available drawdown multiplied by the specific capacity $[150(\mathrm{gal} / \mathrm{min}) / \mathrm{ft}$ ] produces an unrealistically high pumping rate, so a more reasonable rate of $100 \mathrm{gal} / \mathrm{min}$ was used. During well development, well CC-18 behaved nearly identically to well CC-17 (see table 2). Pumping well CC-18 at $16.7 \mathrm{gal} / \mathrm{min}$ produced $0.06 \mathrm{ft}$ of drawdown [specific capacity of $280(\mathrm{gal} / \mathrm{min}) / \mathrm{ft}$ ], while pumping well CC-17 at $17.8 \mathrm{gal} / \mathrm{min}$ produced $0.08 \mathrm{ft}$ of drawdown [specific capacity of $250(\mathrm{gal} / \mathrm{min}) / \mathrm{ft}$ ]. Because the hydraulic characteristics of well CC-18 are similar to those of well CC-17, a rate of $100 \mathrm{gal} / \mathrm{min}$ for well CC-18 also was used. The hydraulic gradient (0.002) was estimated using water levels at the disposal area measured on May 13, 1996, before the start of the disposal area aquifer tests. Pumping wells CC-16 and CC-17 together at a combined rate of $172 \mathrm{gal} / \mathrm{min}$ would form a capture zone ranging from approximately $172 \mathrm{ft}$ wide (transmissivity of $56,200 \mathrm{ft}^{2} / \mathrm{d}$ ) to approximately $400 \mathrm{ft}$ wide (transmissivity of $34,900 \mathrm{ft}^{2} / \mathrm{d}$ ) at a distance $500 \mathrm{ft}$ upgradient from the center of the pumping wells (fig. 53). Pumping wells CC-16, CC-17, and CC-18 together at a combined rate of $270 \mathrm{gal} / \mathrm{min}$ would form a capture zone ranging from approximately $443 \mathrm{ft}$ wide (transmissivity of $56,200 \mathrm{ft}^{2} / \mathrm{d}$ ) to approximately $477 \mathrm{ft}$ wide (transmissivity of $34,900 \mathrm{ft}^{2} / \mathrm{d}$ ) at a distance $500 \mathrm{ft}$ upgradient from the center of the pumping wells (fig. 54).
The capture-zone analysis for the disposal area could be improved by conducting an aquifer test of well CC-17 at a higher pumping rate than was previously conducted and conducting an aquifer test of well CC-18. The aquifer test that was conducted in well CC-17 was limited by pump capacity and the inflow capacity of the carbon unit used to treat the discharge water.

Water from well CC- 5 contains the highest concentrations of VOC's of the wells at the disposal area (appendix 6 , table 2 ). Well CC-5 potentially could be used as a recovery well because it has a high specific capacity. However, because of its shallow depth $(80 \mathrm{ft})$, the available drawdown would be about $35 \mathrm{ft}$. Pumping wells CC-16, CC-17, and CC-18 would probably induce the flow of water with higher concentrations of VOC's to the wells with time. After 23 hours of pumping well CC-16, the concentration of TCE increased from 140 to $170 \mu \mathrm{g} / \mathrm{L}$, TCA from 68 to $99 \mu \mathrm{g} / \mathrm{L}$, and 1,2-dichloroethylene from 200 to $320 \mu \mathrm{g} / \mathrm{L}$; the concentration of PCE remained the same (appendix 6, table 2). After 23 hours of pumping well CC-17, the concentration of TCE increased from 58 to $97 \mu \mathrm{g} / \mathrm{L}$, PCE from 22 to $30 \mu \mathrm{g} / \mathrm{L}$, TCA from 14 to $25 \mu \mathrm{g} / \mathrm{L}$, and 1,2-dichloroethylene from 110 to $220 \mu \mathrm{g} / \mathrm{L}$ (appendix 6, table 2). Pumping well CC-18, which is screened from 184-194 ft bls, may induce the flow of contaminants deeper into the aquifer.

Pumping wells CC-16, CC-17, and CC-18 at a combined rate of $172-272 \mathrm{gal} / \mathrm{min}$ could potentially affect water levels in nearby domestic wells, but the drawdown in these wells would probably be less than $1 \mathrm{ft}$. Domestic wells DW-3, DW-33, DW-36, DW-41, DW-42, DW-43, and DW-44 were measured daily during the aquifer tests of wells CC-16 and CC-17. The water levels in the wells behaved identically, showing an overall declining trend with a slight rise on May 16 from recharge by precipitation. From May 13 and May 17, the net decrease in water level ranged from 0.24 to $0.26 \mathrm{ft}$. The water levels were not affected by pumping during the aquifer tests.

\section{SUMMARY}

The Malvern TCE Site is an active facility operated by the Chemclene Corporation, which sells solvents and formerly recycled them. The site consists of a plant area and a disposal area, which are approximately 1,900 ft apart. The plant area includes the distillation building and a former underground storage tank area. The disposal area once contained two earthen disposal impoundments used to dispose 


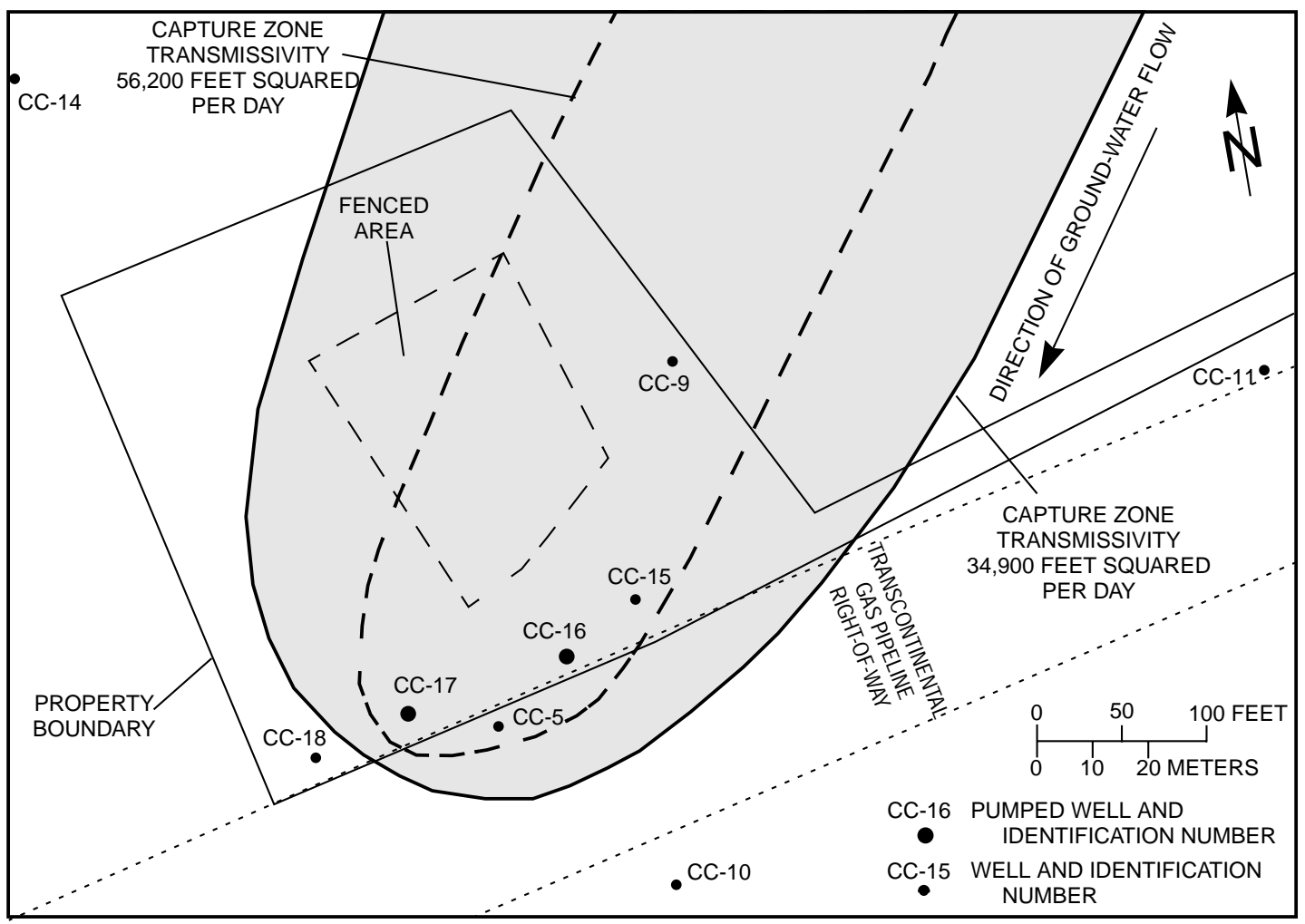

Figure 53. Capture zone formed by pumping wells CC-16 and CC-17 at the disposal area, Malvern TCE Site, Chester County, Pennsylvania.

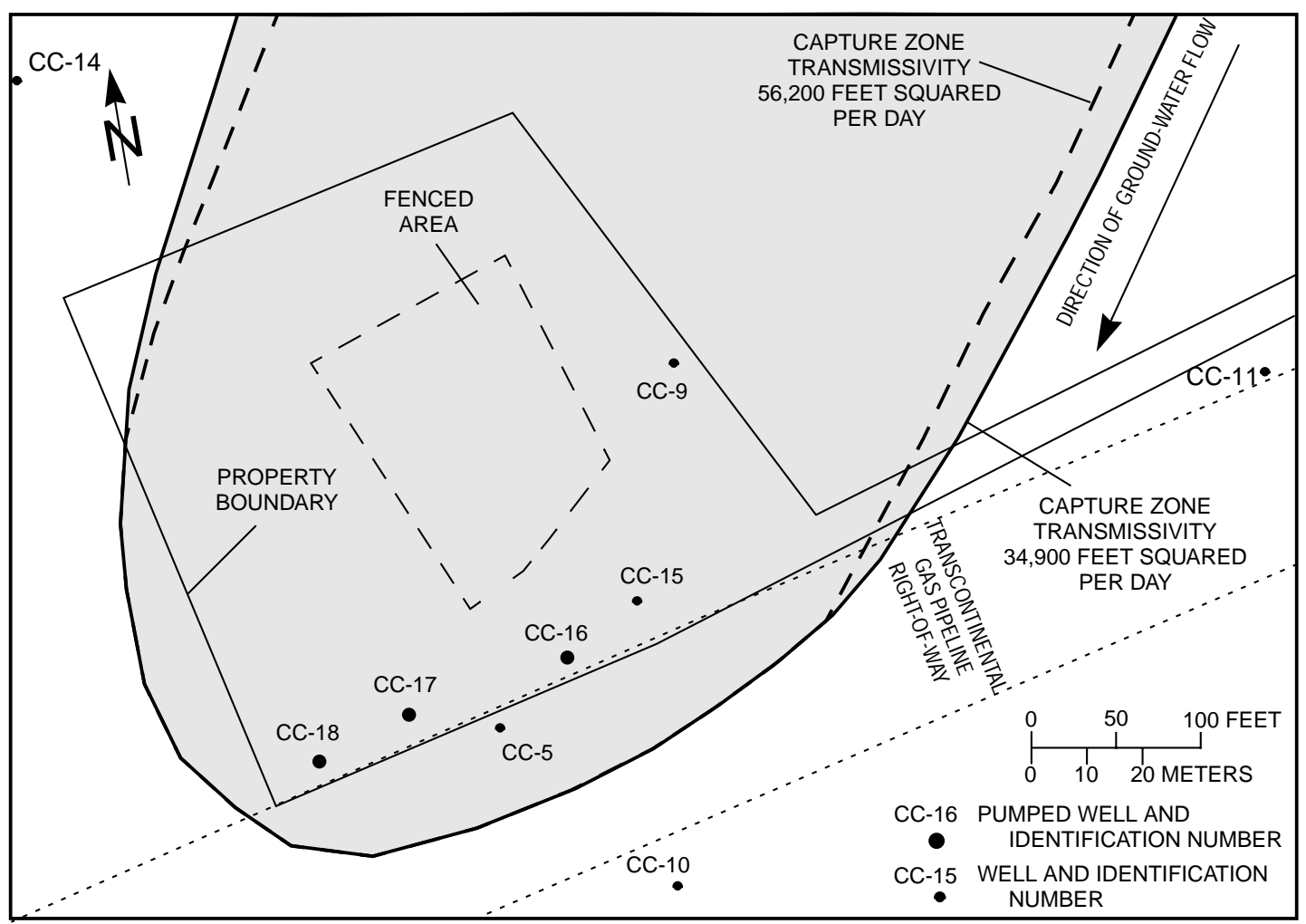

Figure 54. Capture zone formed by pumping wells CC-16, CC-17, and CC-18 at the disposal area, Malvern TCE Site, Chester County, Pennsylvania. 
of drummed distillation residue from Chemclene's solvent recycling process. From 1981 to 1984, the Chemclene Corporation removed all drums and soil to a depth of $15 \mathrm{ft}$. Buried drums of distillation residue found in 1990 were removed from the mounded area; however, contaminated soil remains in place.

The Malvern TCE Site is underlain by a carbonate bedrock aquifer that generally is under unconfined (water-table) conditions and is recharged by local precipitation. Ground water flows through a network of interconnected secondary openings that include joints, faults, bedding planes, and fractures. Primary porosity is insignificant. The primary weathering process is dissolution of dolomite. Secondary openings commonly are enlarged by solution, and permeability is predominately the result of solution-enlarged fractures. Where solution has been active, permeability may be high; elsewhere, the same unit may be nearly impermeable.

Water levels were measured continuously in three wells on site (CC-2, CC-9, and CC-13) and two wells off site (CH-2313 and $\mathrm{CH}-4394)$ and monthly in all wells on site. Water levels respond quickly to precipitation, usually during or immediately following precipitation. Water levels in on-site wells show a similar seasonal variation, response to precipitation, and range of fluctuation. The altitude of water levels in wells at the disposal area is nearly identical because of the small hydraulic gradient.

A comparison of water-table maps for October 1983 during a time of about average water levels, for May and June 1993 during a time of relatively high water levels, and for December 1994 during a time of relatively low water levels shows that the general shape of the water table and hydraulic gradients have remained nearly the same through time and for different climatic conditions.

The plant area is underlain by dolomite of the Elbrook Formation. The dolomite at the plant area is less fractured than the dolomite at the disposal area, which is underlain by the Ledger Dolomite. The mean thickness of the weathered (clay) zone overlying bedrock determined from natural-gamma logs is $55 \mathrm{ft}$, which is similar to that of the disposal area $(58 \mathrm{ft})$.

Five wells (CC-19, CC-20, CC-21, CC-22, and CC-23) were drilled at the plant area for this investigation. In the three wells that did not collapse, only one waterbearing zone in two wells (CC-20 and CC-22) and two water-bearing zones in one well (CC-19) were penetrated to a depth of $303 \mathrm{ft}$ bls. The dolomite at the plant area does not yield as much water as the dolomite at the disposal area because it is less fractured. Yields of nine wells at the plant area range from 1 to $200 \mathrm{gal} / \mathrm{min}$; the median yield is $6 \mathrm{gal} / \mathrm{min}$. Specific capacities and transmissivities are lower at the plant area than at the disposal area. Specific capacity for wells at the plant area ranged from 0.08 to 2 (gal/min)/ft.

Well CC-19 was originally drilled to a depth of $303 \mathrm{ft}$ bls. Water-bearing fractures were penetrated at 145 and $166 \mathrm{ft}$ bls. Borehole geophysical logging and heat-pulse-flowmeter measurements show that water enters the well through fractures at $177 \mathrm{ft}$ bls (0.09 $\mathrm{gal} / \mathrm{min})$ and $166 \mathrm{ft}$ bls $(0.12 \mathrm{gal} / \mathrm{min})$, flows upwards at $0.2 \mathrm{gal} / \mathrm{min}$, and exits the well through the fracture at $145 \mathrm{ft}$ bls. An aquifer-isolation test using an inflatable packer was conducted to determine the yield and VOC concentration of water from each zone. Water levels measured in both zones after water levels had stabilized showed that the water level was $0.15 \mathrm{ft}$ higher in the lower zone than in the upper zone, indicating flow from the lower to the upper zone; this confirmed the heat-pulseflowmeter measurements. VOC concentrations were similar for each zone.

Well CC-19 was pumped for 1,450 minutes (24 hours and 10 minutes) at an average rate of $20.8 \mathrm{gal} / \mathrm{min}$. The drawdown was $35.01 \mathrm{ft}$, and the specific capacity was $0.59(\mathrm{gal} / \mathrm{min}) / \mathrm{ft}$. The median transmissivity estimated from the drawdown and recovery data is 528 and $839 \mathrm{ft}^{2} / \mathrm{d}$, respectively. Well CC-21 was pumped for 1,450 minutes at $15.6 \mathrm{gal} / \mathrm{min}$. The drawdown was $16.03 \mathrm{ft}$, and the specific capacity was $0.97(\mathrm{gal} / \mathrm{min}) / \mathrm{ft}$. The median transmissivity estimated from the drawdown and recovery data for the observation wells is 608 and $588 \mathrm{ft}^{2} / \mathrm{d}$, respectively.

Concentrations of VOC's in ground water are higher at the plant area than at the disposal area. Water samples collected from wells at the plant area in May 1996 had maximum concentrations of TCE of $53,900 \mu \mathrm{g} / \mathrm{L}$, PCE of 7,110 $\mu \mathrm{g} / \mathrm{L}$, and TCA of $17,700 \mu \mathrm{g} / \mathrm{L}$. One percent of solubility for TCE was exceeded in water from wells CC-3, CC-6, CC-7, and CC-13, and 1 percent of solubility for TCA was exceeded in water from well CC-6, indicating the possible presence of a DNAPL. The concentration of TCE in the water sample from well CC-7 is 36 percent of the solubility of TCE, which strongly suggests the presence of a DNAPL. The water sample from well 
CC-7 indicates more biodegradation than water samples from the other plant area wells. The water sample from well CC-7 contains a much higher ratio of dehalogenation product cis-1,2-dichloroethylene to TCE than water from the other wells, and it is the only water sample containing detectable concentrations of dehalogenation products vinyl chloride and chloroethane.

A ground-water divide is located between the plant area and the disposal area. Ground-water withdrawal for dewatering the Catanach quarry has caused a cone of depression in the water-table surface that reaches to the plant area. From the plant area, ground water flows $1.2 \mathrm{mi}$ to the northeast and discharges to the Catanach quarry. The regional hydraulic gradient between the plant and the Catanach quarry is 0.019 . Concentrations of VOC's in water from wells drilled northeast and downgradient of the plant property boundary are one to two orders of magnitude less than concentrations in water from wells less than $100 \mathrm{ft}$ away at the plant.

A capture-zone analysis for the plant area indicates that pumping wells CC-19 and CC-21 together would form a combined capture zone ranging from approximately $393 \mathrm{ft}$ wide (transmissivity of $839 \mathrm{ft}^{2} / \mathrm{d}$ ) to approximately $630 \mathrm{ft}$ wide (transmissivity of $528 \mathrm{ft}^{2} / \mathrm{d}$ ) at a distance $500 \mathrm{ft}$ upgradient from the center of the pumping wells.

Pumping only well CC-19 would form a capture zone ranging from approximately $262 \mathrm{ft}$ wide (transmissivity of $839 \mathrm{ft}^{2} / \mathrm{d}$ ) to approximately $402 \mathrm{ft}$ wide (transmissivity of $528 \mathrm{ft}^{2} / \mathrm{d}$ ) at a distance $500 \mathrm{ft}$ upgradient from well CC-19. Pumping well CC-19 at a rate of $20 \mathrm{gal} / \mathrm{min}$ would be sufficient to capture all ground-water flow from the plant area. Pumping well CC-19 would induce the flow of water with higher concentrations of $\mathrm{VOC}^{\prime}$ s to the well with time but might cause VOC's to move lower into the aquifer.

The disposal area is underlain by the Ledger Dolomite. The dolomite at the disposal area is more fractured than the dolomite at the plant area, which is underlain by the Elbrook Formation. Many of the fractures are filled or partially filled with clay. The mean depth of the weathered (clay) zone overlying bedrock determined from natural-gamma logs is $58 \mathrm{ft}$, which is similar to that of the plant area (55 ft). Four wells (CC-15, CC-16, CC-17, and CC-18) were drilled for this investigation. Because of the highly fractured nature of the rocks and the presence of numerous clay seams, drilling was difficult, and none of the wells drilled for this study would stay open. To construct monitor wells, each well was cased to the bottom, and all loose material was blown out of the casing with compressed air. A filter pack, well screen, and inner casing were placed in the center of the well, and the casing was pulled up to expose the screen.

The dolomite at the disposal area yields more water than the dolomite at the plant area. Yields of eight wells at the disposal area range from 15 to more than $200 \mathrm{gal} / \mathrm{min}$; the median yield is greater than $100 \mathrm{gal} / \mathrm{min}$. Specific capacity for wells at the disposal area ranges from 2 to $280(\mathrm{gal} / \mathrm{min}) / \mathrm{ft}$.

Well CC-16 was pumped for 1,450 minutes at $39.6 \mathrm{gal} / \mathrm{min}$, the maximum pump capacity. The drawdown was $19.33 \mathrm{ft}$, and the specific capacity was $2(\mathrm{gal} / \mathrm{min}) / \mathrm{ft}$. The water level in well CC-16 decreased to $23.66 \mathrm{ft}$ in 5.5 minutes, stabilized, and then began to rise. This was caused by clay-filled fractures becoming unplugged or partially unplugged and providing additional water to the well. Complete recovery of the water level in well CC-16 took 0.8 minutes. The median transmissivity estimated from the recovery data for observation wells is $34,900 \mathrm{ft}^{2} / \mathrm{d}$. Well CC-17 was pumped for 1,450 minutes at $43.2 \mathrm{gal} / \mathrm{min}$, the maximum pump capacity. The drawdown was $0.28 \mathrm{ft}$, and the specific capacity was 150 (gal/min)/ft. Small drawdowns in the pumped and observation wells indicate that the aquifer was not sufficiently stressed to produce reliable results. Transmissivity estimated from the specific capacity is $56,200 \mathrm{ft}^{2} / \mathrm{d}$.

Concentrations of VOC's in ground water are lower at the disposal area than concentrations at the plant area. Water samples collected from wells at the disposal area in 1996 had maximum concentrations of TCE of $768 \mu \mathrm{g} / \mathrm{L}$, PCE of $111 \mu \mathrm{g} / \mathrm{L}$, and TCA of $108 \mu \mathrm{g} / \mathrm{L}$. These concentrations are lower than concentrations in water samples collected before cleanup of the disposal area was completed in 1984. Water samples collected in 1996 from wells CC-5, CC-10, CC-16, CC-17, and CC-18 contain a higher concentration of dehalogenation product cis-1,2-dichloroethylene than of TCE or PCE; this may indicate that since the source has been removed, the VOC's remaining in the ground water are degrading.

Ground water from the disposal area flows south-southeast toward Valley Creek. The hydraulic gradient between the disposal area and Valley Creek is 0.001 , which is less than one-tenth of the hydraulic 
gradient at the plant area. The low hydraulic gradient and relatively flat water table are reflective of the high transmissivity of the aquifer in this area.

A well defined plume of VOC's in ground water extends downgradient from the disposal area toward Valley Creek. Water samples from off-site wells collected in 1995 showed maximum concentrations of TCE of $56.5 \mu \mathrm{g} / \mathrm{L}, \mathrm{PCE}$ of $10.7 \mu \mathrm{g} / \mathrm{L}$, and TCA of $10.7 \mu \mathrm{g} / \mathrm{L}$. A comparison of data from 1995 (appendix 6, table 3) with data from 1981 to 1984 (CH2M HILL, Inc., 1995) shows that concentrations of TCE, PCE, and TCA in water from most off-site wells have decreased and that water from fewer wells contains detectable concentrations of those compounds. The decrease in concentrations and number of wells affected is most likely caused by cleanup of the disposal area.

A capture-zone analysis performed for the disposal area indicates that pumping wells CC-16 and CC-17 together at a combined rate of $172 \mathrm{gal} / \mathrm{min}$ would form a capture zone ranging from approximately $172 \mathrm{ft}$ wide (transmissivity of $56,200 \mathrm{ft}^{2} / \mathrm{d}$ ) to approximately $400 \mathrm{ft}$ wide (transmissivity of $34,900 \mathrm{ft}^{2} / \mathrm{d}$ ) at a distance $500 \mathrm{ft}$ upgradient from the center of the pumping wells. Pumping wells CC-16, CC-17, and CC-18 together at a combined rate of $270 \mathrm{gal} / \mathrm{min}$ would form a capture zone ranging from approximately $443 \mathrm{ft}$ wide (transmissivity of $56,200 \mathrm{ft}^{2} / \mathrm{d}$ ) to approximately $477 \mathrm{ft}$ wide (transmissivity of $34,900 \mathrm{ft}^{2} / \mathrm{d}$ ) at a distance $500 \mathrm{ft}$ upgradient from the center of the pumping wells.

\section{REFERENCES CITED}

Bascom, Florence, and Stose, G., 1938, Geology and mineral resources of the Honeybrook and Phoenixville quadrangles, Pennsylvania: U.S. Geological Survey Bulletin 891, 145 p.

Bierschenk, W.H., 1963, Determining well efficiency by multiple step-drawdown tests: International Association of Scientific Hydrology Publication 64, p. 493-507.

CH2M HILL, Inc., 1995, Final data summary report for Malvern TCE Site: Philadelphia, Pennsylvania, 2 vols.

1997, Remedial investigation report for Malvern TCE Site: Philadelphia, Pennsylvania, 2 vols.
Chemclene Corporation, 1992, RCRA corrective action order response submittal: Malvern, Pennsylvania.

1993, Interim report on the results of pumping tests on Chemclene Corporation monitoring well CC-05: Malvern, Pennsylvania.

Cohen, R.M., and Mercer, J.W., 1993, DNAPL site evaluation: C.K. Smoley, Boca Raton, variously paginated.

Cooper, H.H., Jr., and Jacob, C.E., 1946, A generalized graphical method for evaluating formation constants and summarizing wellfield history: Transactions, American Geophysical Union, v. 27, p. 526-534.

Crawford, M.L., and Crawford, W.A., 1980, Metamorphic and tectonic history of the Pennsylvania piedmont: Journal of the Geological Society of London, v. 137, p. 311-320.

Crawford, W.A., and Hoersch, A.L., 1984, The geology of the Honey Brook upland, southeastern Pennsylvania: Geological Society of America Special Paper 194, p. 111-125.

Dames and Moore, Inc., 1989a, USEPA submittal RFI workplan Chemclene Corporation, Malvern, Pennsylvania: unpublished report.

1989b, Addendum USEPA submittal RFI workplan Chemclene Corporation, Malvern, Pennsylvania: unpublished report.

Earth Data, Inc., 1984, Ground-water retrieval plan for the former disposal area: St. Michaels, Maryland, and West Chester, Pennsylvania, $24 \mathrm{p}$.

1986, Workplan to complete remedial investigation and feasibility study for the Malvern TCE Superfund Site: St. Michaels, Maryland, and West Chester, Pennsylvania, $23 \mathrm{p}$.

1991, USEPA submittal addendum to RFI workplan Chemclene Corporation, Malvern, Pennsylvania: Exton, Pennsylvania. 
1992, Chemclene Corporation modification

to RFI workplan - pumping tests:

Correspondence to USEPA dated November 6, 1992.

Goodwin, P.W., and Anderson, E.J., 1974, Associated physical and biogenic structures in environmental subdivision of a Cambrian tidal body: Journal of Geology, v. 82, p. 779-794.

Javandel, Iraj, Doughty, Christine, and Tsang, Chin-Fu, 1984, Groundwater transportHandbook of mathematical models: American Geophysical Union Water Resources Monograph 10, 228 p.

Kauffman, M.E., and Frey, E.P., 1979, Antietam sandstone ridges-exhumed barrier islands or fault-bound blocks [ABS]: Geological Society of America Abstracts with Programs, Northeastern Section, v. 11, no. 1, p. 18.

Keys, W.S., 1990, Borehole geophysics applied to ground-water investigations: U.S. Geological Survey Techniques of Water-Resources Investigations, book 2, chap. E2, 149 p.

Lohman, S.W, 1972, Definitions of selected ground-water terms-revisions and conceptual refinements: U.S. Geological Survey Water-Supply Paper 1988, 21 p.

Lyttle, P.T., and Epstein, J.B., 1987, Geologic map of the Newark $1^{\circ} \times 2^{\circ}$ quadrangle, New Jersey, Pennsylvania, and New York: U.S. Geological Survey Miscellaneous Investigations Series I-1715, 2 plates, scale $1: 250,000$.

MacLachlan, D.B., 1994a, Some aspects of the Lower Paleozoic Laurentian margin and slope in Southeastern Pennsylvania: in Faill, R.T., and Sevon, W.D., eds., Various aspects of Piedmont geology in Lancaster and Chester Counties, Pennsylvania: Field Conference of Pennsylvania Geologists, Inc., Guidebook for 59th Annual Field Conference of Pennsylvania Geologists, p. 3-23. 1994b, Stop 3. General Crushed Stone Company, Downingtown Quarry; Ledger, Zooks Corner, and Henderson Marble Formations in Faill, R.T., and Sevon, W.D., eds., Various aspects of Piedmont geology in Lancaster and Chester Counties, Pennsylvania: Field Conference of Pennsylvania Geologists, Inc., Guidebook for 59th Annual Field Conference of Pennsylvania Geologists, p. 150-153.

McManus, B.C., and Sloto, R.A., 1993, Altitude and configuration of the potentiometric surface, May and June 1993, and change in water level 1983-93, in the carbonate rocks in part of East Whiteland and Charlestown Townships, Chester County, Pennsylvania: U.S. Geological Survey OpenFile Report 93-659, 1 plate, scale 1:24,000.

1996, Altitude and configuration of the potentiometric surface, December 6, 1994, in the carbonate rocks in part of East Whiteland and Charlestown Townships, Chester County, Pennsylvania: U.S. Geological Survey OpenFile Report 96-367, 1 plate, scale 1:24,000.

Moorshead-Siddiqui and Associates, 1982, Groundwater quality investigation for Chemclene Corporation, Malvern, Pennsylvania: St. Michaels, Maryland, and West Chester, Pennsylvania, 10 p.

Neuman, S.P., 1975, Analysis of pumping test data from anisotropic unconfined aquifers considering delayed gravity response: Water Resources Research, v. 11, p. 329-342.

Owenby, J.R., and Ezell, D.S., 1992, Monthly station normals of temperature, precipitation, and heating and cooling degree days, 19611990, Pennsylvania: National Oceanic and Atmospheric Administration Climatography of the United States, no. 81, 25 p.

Rodgers, John, 1968, The eastern edge of the North American continent during the Cambrian and early Ordovician, in Zen, E. White, W.S., Hadley, J.B., and Thompson, J.B., Jr., Studies of Appalachian Geology: New York, Interscience Publishers, p. 141-149. 
Schwab, F.L., 1970, Petrology, paleocurrents, and depositional environment of the Harpers Formation in the central Appalachians [ABS]: Geological Society of America Abstracts with Program, Northeast Section, v. 2, no. 1, p. 35.

Sloto, R.A, 1987, Effect of urbanization on the water resources of eastern Chester County, Pennsylvania: U.S. Geological Survey WaterResources Investigations Report 87-4098, $131 \mathrm{p}$.

1989, Selected ground-water data, Chester County, Pennsylvania: U.S. Geological Survey Open-File Report 87-217, 198 p.

1990, Geohydrology and simulation of ground-water flow in the carbonate rocks of the Valley Creek basin, eastern Chester County, Pennsylvania: U.S. Geological Survey Water-Resources Investigations Report 89-4169, 60 p.

1994, Geology, hydrology, and groundwater quality, Chester County, Pennsylvania: Chester County Water Resources Authority Water-Resource Report 2, 127 p.
Theis, C.V., 1935, The relation between the lowering of the piezometric surface and the rate and duration of discharge of a well using groundwater storage: Transactions, American Geophysical Union, v. 16, p. 519-524.

Theis, C.V., Brown, R.H., and Meyer, R.R., 1963, Estimating the transmissibility of aquifers from the specific capacity of wells in Bentall, Ray (comp.), Methods of determining permeability, transmissibility, and drawdown: U.S. Geological Survey Water Supply Paper 1536-I, p. 331-340.

Todd, D.K., 1980, Groundwater hydrology (2nd ed.): New York, John Wiley and Sons, 535 p.

U.S. Environmental Protection Agency, 1992, Superfund: Progress at National Priority List Sites: U.S. Environmental Protection Agency Office of Emergency and Remedial Response, Publication 9200.5-738B, 277 p.

Wagner, M.E., and Srogi, Leeann, 1987, Early Paleozoic metamorphism at two crustal levels and a tectonic model for the PennsylvaniaDelaware piedmont: Geological Society of America Bulletin, v. 99, p. 113-126. 


\section{APPENDIX 1. RECORD OF OFF-SITE WELLS}


Table 1. Record of off-site wells near the Malvern TCE Site, Chester County, Pennsylvania

[gal/min, gallons per minute; MSL, mean sea level; --, no data; >, greater than; PVC, polyvinyl chloride]

\begin{tabular}{|c|c|c|c|c|c|c|c|c|}
\hline $\begin{array}{c}\text { Off-site well- } \\
\text { identification } \\
\text { number }\end{array}$ & $\begin{array}{c}\text { U.S. } \\
\text { Geological } \\
\text { Survey well- } \\
\text { identification } \\
\text { number }\end{array}$ & $\begin{array}{l}\text { Well } \\
\text { depth } \\
\text { (feet) }\end{array}$ & $\begin{array}{c}\text { Well } \\
\text { diameter } \\
\text { (inches) }\end{array}$ & $\begin{array}{c}\text { Casing } \\
\text { length } \\
\text { (feet) }\end{array}$ & $\begin{array}{c}\text { Yield } \\
\text { (gal/min) }\end{array}$ & $\begin{array}{l}\text { Depth to } \\
\text { water (feet } \\
\text { below land } \\
\text { surface) }{ }^{1}\end{array}$ & $\begin{array}{l}\text { Land surface } \\
\text { elevation (feet } \\
\text { above MSL) }\end{array}$ & $\begin{array}{l}\text { Water level } \\
\text { elevation (feet } \\
\text { above MSL) }\end{array}$ \\
\hline DW-1 & -- & -- & -- & -- & -- & -- & 328.7 & -- \\
\hline DW-2 & $\mathrm{CH}-5159$ & 60 & 6 & 54 & 45 & -- & -- & -- \\
\hline DW-3 & -- & 90 & 6 & 68 & 30 & -- & 377.09 & -- \\
\hline DW-4 & $\mathrm{CH}-5134$ & 77 & 6 & 65 & 15 & 36.20 & 341.54 & 305.34 \\
\hline DW-5 & $\mathrm{CH}-5161$ & 60 & 6 & 48 & 12 & -- & -- & -- \\
\hline DW-6 & $\mathrm{CH}-5162$ & 94 & 6 & 90 & 20 & -- & -- & -- \\
\hline DW-7 & $\mathrm{CH}-5126$ & 100 & 6 & 79 & 15 & 52.28 & 358.10 & 305.82 \\
\hline DW-9 & $\mathrm{CH}-5129$ & -- & 6 & -- & -- & 53.46 & 359.97 & 306.5 \\
\hline DW-10 & $\mathrm{CH}-2551$ & 199 & 6 & 60 & 8 & 275.26 & 366.0 & 291 \\
\hline DW-12 & $\mathrm{CH}-2536$ & -- & 6 & -- & -- & 34.63 & 339.95 & 305.32 \\
\hline DW-15 & -- & -- & -- & -- & -- & -- & -- & -- \\
\hline DW-16 & CH-4399 & 120 & 6 & -- & -- & -- & -- & -- \\
\hline DW-17 & $\mathrm{CH}-2550$ & 100 & 6 & 87 & 15 & -- & -- & -- \\
\hline DW-19 & $\mathrm{CH}-2564$ & 180 & 6 & 60 & 50 & 59.24 & 364.26 & 305.02 \\
\hline DW-20 & $\mathrm{CH}-4397$ & 200 & 6 & 142 & 50 & 52.44 & 352.80 & 300.36 \\
\hline DW-23 & $\mathrm{CH}-2566$ & 85 & 6 & -- & 20 & -- & -- & -- \\
\hline DW-30 & $\mathrm{CH}-2516$ & -- & -- & -- & -- & -- & -- & -- \\
\hline DW-31 & $\mathrm{CH}-5158$ & 100 & 6 & 90 & $>50$ & -- & -- & -- \\
\hline DW-32 & $\mathrm{CH}-5156$ & 148 & 6 & 105 & 12 & -- & -- & -- \\
\hline DW-33 & $\mathrm{CH}-4400$ & -- & 6 & -- & -- & 43.50 & 348.60 & 305.10 \\
\hline DW-36 & CH-2438 & 80 & 6 & 65 & 10 & 40.92 & 346.08 & 305.16 \\
\hline DW-41 & $\mathrm{CH}-5130$ & -- & 6 & -- & -- & 44.00 & 349.18 & 305.18 \\
\hline DW-42 & $\mathrm{CH}-5135$ & 60 & 6 & -- & -- & 35.83 & 341.02 & 305.19 \\
\hline DW-43 & $\mathrm{CH}-4401$ & 75 & 6 & 65 & 10 & 38.34 & 347.58 & 309.24 \\
\hline DW-44 & $\mathrm{CH}-5131$ & 57 & 6 & -- & -- & 36.09 & 341.35 & 305.26 \\
\hline DW-45 & -- & -- & -- & -- & -- & -- & -- & -- \\
\hline DW-46 & -- & -- & -- & -- & -- & -- & -- & -- \\
\hline DW-47 & -- & -- & -- & -- & -- & -- & -- & -- \\
\hline DW-48 & -- & -- & -- & -- & -- & -- & -- & -- \\
\hline DW-49 & $\mathrm{CH}-5136$ & 150 & 6 & 50 & 20 & 32.96 & 341.04 & 308.08 \\
\hline DW-50 & -- & -- & -- & -- & -- & -- & -- & -- \\
\hline DW-51 & CH-2512 & 82 & 6 & 63 & 60 & 27.34 & 332.54 & 305.20 \\
\hline DW-52 & $\mathrm{CH}-5140$ & 115 & 6 & -- & 50 & 39.06 & 344.34 & 305.28 \\
\hline DW-53 & $\mathrm{CH}-5133$ & 128 & 6 & 120 & 30 & 41.34 & 346.65 & 305.31 \\
\hline DW-54 & -- & -- & -- & -- & -- & -- & -- & -- \\
\hline DW-55 & $\mathrm{CH}-5128$ & 103 & 6 & 80 & -- & 40.92 & 346.20 & 305.28 \\
\hline DW-56 & -- & -- & -- & -- & -- & -- & -- & -- \\
\hline DW-57 & $\mathrm{CH}-5127$ & 80 & 6 & 77 & 50 & 51.78 & 357.54 & 305.76 \\
\hline DW-58 & $\mathrm{CH}-2538$ & 100 & 6 & 40 & 20 & 55.17 & 362.96 & 307.79 \\
\hline DW-60 & $\mathrm{CH}-5125$ & 65 & 6 & & & 42.74 & 351.07 & 308.33 \\
\hline DW-61 & $\mathrm{CH}-5139$ & 80 & 6 & & & 42.00 & 349.16 & 307.16 \\
\hline DW-62 & -- & -- & -- & -- & -- & -- & -- & -- \\
\hline DW-63 & -- & -- & -- & -- & -- & -- & -- & -- \\
\hline DW-64 & $\mathrm{CH}-5141$ & 100 & 6 & 80 & 10 & 34.78 & 341.35 & 306.57 \\
\hline DW-65 & $\mathrm{CH}-5157$ & 160 & 6 & 60 & 50 & -- & 368.98 & -- \\
\hline DW-66 & $\mathrm{CH}-2540$ & 80 & 6 & 60 & 100 & 24.00 & 327.04 & 303.04 \\
\hline DW-67 & -- & -- & -- & -- & -- & -- & -- & -- \\
\hline DW-69 & $\mathrm{CH}-2539$ & 98 & 6 & 82 & 10 & 21.45 & 326.94 & 305.49 \\
\hline DW-70 & -- & -- & -- & -- & -- & -- & -- & -- \\
\hline DW-71 & -- & -- & -- & -- & -- & -- & -- & -- \\
\hline
\end{tabular}


Table 1. Record of off-site wells near the Malvern TCE Site, Chester County, Pennsylvania-Continued [gal/min, gallons per minute; MSL, mean sea level; --, no data; >, greater than; PVC, polyvinyl chloride]

\begin{tabular}{|c|c|c|c|c|c|c|c|c|}
\hline $\begin{array}{c}\text { Off-site well- } \\
\text { identification } \\
\text { number }\end{array}$ & $\begin{array}{c}\text { U.S. } \\
\text { Geological } \\
\text { Survey well- } \\
\text { identification } \\
\text { number }\end{array}$ & $\begin{array}{l}\text { Well } \\
\text { depth } \\
\text { (feet) }\end{array}$ & $\begin{array}{c}\text { Well } \\
\text { diameter } \\
\text { (inches) }\end{array}$ & $\begin{array}{l}\text { Casing } \\
\text { length } \\
\text { (feet) }\end{array}$ & $\begin{array}{c}\text { Yield } \\
\text { (gal/min) }\end{array}$ & $\begin{array}{l}\text { Depth to } \\
\text { water (feet } \\
\text { below land } \\
\text { surface) }\end{array}$ & $\begin{array}{l}\text { Land surface } \\
\text { elevation (feet } \\
\text { above MSL) }\end{array}$ & $\begin{array}{l}\text { Water level } \\
\text { elevation (feet } \\
\text { above MSL) }\end{array}$ \\
\hline DW-100 & -- & -- & -- & -- & -- & -- & -- & -- \\
\hline DW-200 & -- & -- & -- & -- & -- & -- & -- & -- \\
\hline-- & $\mathrm{CH}-79$ & 200 & 6 & 20 & -- & 26.46 & 348.90 & 322.44 \\
\hline-- & $\mathrm{CH}-89$ & 265 & 6 & 112 & 30 & 164.12 & 365 & 200.88 \\
\hline-- & $\mathrm{CH}-269$ & 135 & 6 & 131 & 14 & 82.35 & 391.22 & 308.87 \\
\hline-- & CH-1979 & 90 & 6 & 57 & 45 & 28 & 352 & 334 \\
\hline-- & $\mathrm{CH}-2111$ & 200 & 6 & 20 & -- & 26.46 & 348.90 & 322.44 \\
\hline-- & $\mathrm{CH}-2142$ & 160 & 6 & -- & -- & 84.04 & 364 & 279.96 \\
\hline-- & CH-2199 & -- & -- & -- & -- & 13.49 & 317.08 & 303.59 \\
\hline-- & $\mathrm{CH}-2313$ & 507 & 6 & 22 & $>75$ & 11.00 & 321.20 & 316.20 \\
\hline-- & $\mathrm{CH}-2509$ & 141 & 6 & 72 & 9 & 59.30 & 439 & 379.70 \\
\hline-- & $\mathrm{CH}-2524$ & 107 & 6 & 107 & -- & 22.11 & 422 & 399.89 \\
\hline-- & $\mathrm{CH}-2528$ & 146 & 6 & -- & 25.0 & 85.93 & 394.77 & 308.84 \\
\hline-- & CH-2529 & 95 & 6 & -- & 5 & 67.69 & 377.06 & 309.37 \\
\hline-- & $\mathrm{CH}-2530$ & 121 & 6 & 89 & 15 & 61.76 & 370.48 & 308.72 \\
\hline-- & $\mathrm{CH}-2531$ & -- & 6 & -- & -- & 83.58 & 420 & 336.42 \\
\hline-- & $\mathrm{CH}-2541$ & -- & 6 & -- & -- & 44.61 & 315 & 270.39 \\
\hline-- & $\mathrm{CH}-2547$ & 125 & 6 & -- & -- & 36.92 & 368 & 331.08 \\
\hline-- & CH-2549 & -- & 6 & -- & -- & 77.22 & 353.13 & 275.91 \\
\hline-- & $\mathrm{CH}-2553$ & 181 & 6 & 157 & 100 & 107.73 & 344 & 236.27 \\
\hline-- & $\mathrm{CH}-2561$ & -- & 6 & 229 & -- & 160.0 & 337.10 & 177.10 \\
\hline-- & $\mathrm{CH}-2563$ & 195 & 6 & -- & -- & 101.61 & 360.50 & 258.89 \\
\hline-- & $\mathrm{CH}-2616$ & 80 & 6 & -- & -- & 11.52 & 313.25 & 301.73 \\
\hline-- & $\mathrm{CH}-2626$ & -- & 6 & -- & -- & 133.95 & 366 & 232.05 \\
\hline-- & $\mathrm{CH}-4392$ & 63.95 & 6 & -- & -- & Dry & 349.74 & -- \\
\hline-- & $\mathrm{CH}-4393$ & 74.30 & $\begin{array}{l}6 \text { steel } \\
4 \text { PVC }\end{array}$ & -- & -- & 66.81 & 346.37 & 279.56 \\
\hline-- & $\mathrm{CH}-4394$ & 102.55 & 6 & -- & -- & 69.77 & 344.82 & 275.05 \\
\hline-- & $\mathrm{CH}-4402$ & 280 & 6 & 63 & 4 & 67.49 & 387 & 319.51 \\
\hline-- & $\mathrm{CH}-4403$ & 247 & 6 & 42 & 27 & 106.50 & 332.90 & 226.40 \\
\hline-- & $\mathrm{CH}-4407$ & -- & 6 & -- & -- & 77.09 & 396 & 318.91 \\
\hline-- & $\mathrm{CH}-4492$ & 98 & 6 & -- & -- & 79.87 & 360.93 & 281.06 \\
\hline-- & $\mathrm{CH}-4494$ & 105 & $\begin{array}{l}6 \text { steel } \\
4 \text { PVC }\end{array}$ & -- & -- & 84.46 & 364.38 & 279.92 \\
\hline-- & $\mathrm{CH}-5138$ & -- & 6 & -- & 5 & 67.69 & 377.06 & 309.37 \\
\hline
\end{tabular}

${ }^{1}$ Water levels measured on December 6, 1994.

${ }^{2}$ Water level recovering after recent pumping. 


\section{APPENDIX 2. GEOLOGIC LOGS}


Table 1. Geologic log for well CC-15, Malvern TCE Site, Chester County, Pennsylvania

[Well drilled October 19-November 6, 1995.]

\begin{tabular}{|c|c|c|}
\hline $\begin{array}{c}\text { Depth below } \\
\text { land surface (feet) }\end{array}$ & Lithologic description & Comments \\
\hline $0-7.7$ & Clay, orange-brown & \\
\hline $7.7-11$ & Clay, tan to yellow, with quartzite pebbles to cobbles & \\
\hline $11-16.5$ & Clay, orange & Slightly damp \\
\hline $16.5-17$ & Clay, orange, darker, with small quartzite chips, sandy & \\
\hline $17-23$ & Clay, tan to yellow, sandy & \\
\hline 23-28 & Clay, tan to yellow, sandy, some quartzite cobbles & \\
\hline $28-29$ & Clay, tan to yellow, with interbedded white, plastic clay with red inclusions & \\
\hline $29-33$ & Clay, orange-brown, with some white, plastic clay with pebble inclusions & \\
\hline 33-36 & Clay, dark brown & \\
\hline $36-37$ & Clay, orange-brown & \\
\hline $37-42$ & Clay, dark brown & \\
\hline 42 & Clay, dark brown, with limestone fragments & \\
\hline $42-50$ & Clay, brown, with some sand and limestone cobbles & \\
\hline $50-55$ & Clay, brown, with gray-white limestone fragments & \\
\hline $55-60$ & Dolomite, light gray, weathered & \\
\hline $60-65$ & & No returns \\
\hline $65-75$ & Dolomite, light to dark gray, weathered & $\begin{array}{l}\text { Some water at } 67-68 \text { feet, } \\
\text { cased off }\end{array}$ \\
\hline $75-85$ & Dolomite, light to dark gray, weathered & \\
\hline $85-90$ & & No returns \\
\hline $90-105$ & Dolomite, light to dark gray, weathered & \\
\hline $105-115$ & Dolomite, light to dark gray, weathered, with white limestone fragments & \\
\hline $115-120$ & Dolomite, light to dark gray, weathered & \\
\hline $120-125$ & $\begin{array}{l}\text { Dolomite, light gray, to dark weathered, with some dark gray limestone } \\
\text { fragments }\end{array}$ & \\
\hline $125-130$ & Dolomite, light to dark gray, weathered, with white limestone fragments & \\
\hline $130-140$ & Dolomite, light to dark gray, weathered & $\begin{array}{l}\text { Water }(200+\text { gallons per } \\
\text { minute) at } 139 \text { feet }\end{array}$ \\
\hline $140-145$ & Dolomite, light to dark gray, weathered, with white limestone fragments & \\
\hline $145-150$ & Dolomite, light to dark gray, weathered and limestone, white to dark gray & \\
\hline
\end{tabular}


Table 2. Geologic log for well CC-16, Malvern TCE Site, Chester County, Pennsylvania

[Well drilled December 1-7, 1995; XRD, X-ray diffraction analysis]

\begin{tabular}{|c|c|c|}
\hline $\begin{array}{l}\text { Depth below } \\
\text { land surface (feet) }\end{array}$ & Lithologic description & Comments \\
\hline $0-10$ & Clay, orange & \\
\hline $10-23$ & Clay, yellow-tan, with white-gray quartzite fragments & \\
\hline $23-28$ & $\begin{array}{l}\text { Clay, orange-brown, with white-gray quartzite fragments and } \\
\text { white kaolin nodules }\end{array}$ & Kaolin identified by XRD \\
\hline $28-33$ & Clay, tan-orange-brown & \\
\hline $33-63$ & Clay, orange-brown with some sand and white kaolin nodules & \\
\hline $63-80$ & & No returns \\
\hline $80-85$ & Dolomite, light blue-gray & \\
\hline $85-90$ & Dolomite, gray-brown & \\
\hline $90-110$ & Dolomite, gray-brown, with very small white limestone fragments & \\
\hline $110-120$ & $\begin{array}{l}\text { Dolomite, gray-brown, with very small white limestone fragments } \\
\text { and quartz crystals }\end{array}$ & \\
\hline $120-125$ & & $\begin{array}{l}\text { Large fracture, water at } 124 \text { feet, } \\
\text { no returns }\end{array}$ \\
\hline $1125-135$ & $\begin{array}{l}\text { Dolomite, medium dark gray, with quartz crystals and veins and } \\
\text { abundant red clay }\end{array}$ & $\begin{array}{l}\text { Clay identified as phlogophite and } \\
\text { illite by XRD }\end{array}$ \\
\hline${ }^{1} 135-140$ & $\begin{array}{l}\text { Dolomite, medium dark gray, with quartz crystals and veins, } \\
\text { calcite, and some red clay }\end{array}$ & \\
\hline
\end{tabular}

\footnotetext{
${ }^{1}$ Returns from below 125 feet below land surface probably mixed because borehole was collapsing.
} 
Table 3. Geologic log for well CC-18, Malvern TCE Site, Chester County, Pennsylvania

[Well drilled December 1995-January 1996.]

\begin{tabular}{|c|c|c|}
\hline $\begin{array}{l}\text { Depth below } \\
\text { land surface (feet) }\end{array}$ & Lithologic description & Comments \\
\hline $0-15$ & & No returns \\
\hline $15-25$ & Clay, light reddish brown to tan, and sand & \\
\hline $25-35$ & Clay, light yellowish brown to tan, and sand & \\
\hline $35-45$ & Clay, light orange brown to tan, and sand & \\
\hline $45-75$ & Dolomite, medium brown-gray & \\
\hline $75-85$ & Dolomite, medium brown-gray, weathered & \\
\hline $85-105$ & Dolomite, gray & \\
\hline $105-120$ & & No returns \\
\hline $120-135$ & Dolomite, tan to gray, weathered, iron oxide stained & \\
\hline $140-160$ & & Water at 140 feet, no returns \\
\hline $160-165$ & $\begin{array}{l}\text { Dolomite, tan to gray, weathered, iron oxide stained; and quartz sheets } \\
\text { to } 1 / 8 \text { inch thick }\end{array}$ & \\
\hline $165-170$ & $\begin{array}{l}\text { Dolomite, tan to gray, weathered, iron oxide stained; quartz sheets; and } \\
\text { pink clay }\end{array}$ & \\
\hline $170-175$ & $\begin{array}{l}\text { Dolomite, tan to gray and brown, weathered, iron oxide stained; quartz, } \\
\text { crystals and sheets }\end{array}$ & \\
\hline $175-185$ & $\begin{array}{l}\text { Dolomite, tan to gray and brown, weathered, some iron oxide staining; } \\
\text { quartz, crystals and massive; red and pink clay }\end{array}$ & Water at 180 feet \\
\hline $185-190$ & $\begin{array}{l}\text { Dolomite, tan to gray, weathered, some iron oxide staining; quartz } \\
\text { crystals, }\end{array}$ & \\
\hline $190-195$ & Dolomite, tan to gray, some iron oxide staining; pink clay & \\
\hline $195-200$ & Dolomite, tan to gray, some iron oxide staining & \\
\hline $200-205$ & Dolomite, tan to gray and brown; quartz crystals & \\
\hline
\end{tabular}


Table 4. Geologic log for well CC-19, Malvern TCE Site, Chester County, Pennsylvania

[Well drilled March 25-27, 1996.]

\begin{tabular}{|c|c|c|}
\hline $\begin{array}{c}\text { Depth below } \\
\text { land surface (feet) }\end{array}$ & Lithologic description & Comments \\
\hline $0-5$ & Soil, medium dark brown & \\
\hline $5-8$ & Clay, gray to tan & \\
\hline 8-18 & Clay, orange to tan & \\
\hline $18-25$ & Clay, white to tan, sandy & \\
\hline $25-33$ & Clay, orange to tan, sandy & \\
\hline $33-47$ & Clay, brown with gray inclusions & \\
\hline $47-65$ & Dolomite, gray; and clay, gray and brown & \\
\hline $65-75$ & Dolomite, light gray & \\
\hline $75-145$ & Dolomite, light gray and tan & \\
\hline $145-150$ & Dolomite, light gray and tan, some banding, weathered & $\begin{array}{l}\text { Water ( } 5 \text { gallons per minute) } \\
\text { at } 145 \text { feet }\end{array}$ \\
\hline $150-175$ & Dolomite, medium gray, banded, weathered & $\begin{array}{l}\text { Water ( } 20 \text { gallons per minute) } \\
\text { at } 166 \text { feet }\end{array}$ \\
\hline $175-240$ & Dolomite, medium gray, banded, slightly weathered & \\
\hline $240-245$ & Dolomite, medium gray to blue, slightly weathered & \\
\hline $245-250$ & Dolomite, medium gray, banded, slightly weathered & \\
\hline $250-265$ & Dolomite, medium gray to blue, blue banding, slightly weathered & \\
\hline $265-270$ & Dolomite, medium gray to blue, slightly weathered & \\
\hline $270-275$ & Dolomite, blue & \\
\hline $275-285$ & Dolomite, medium gray and blue, some banding, slightly weathered & \\
\hline $285-290$ & Dolomite, blue & \\
\hline $290-303$ & Dolomite, dark blue & \\
\hline
\end{tabular}

Table 5. Geologic log for well CC-20, Malvern TCE Site, Chester County, Pennsylvania [Well drilled March 1-11, 1996.]

\begin{tabular}{cll}
\hline $\begin{array}{c}\text { Depth below } \\
\text { land surface (feet) }\end{array}$ & & \multicolumn{1}{c}{ Lithologic description } \\
\hline $0-15$ & Clay and soil & Comments \\
$15-30$ & Clay with tan to gray dolomite fragments & \\
$30-35$ & Dolomite fragments, tan to gray; goethite & No sample \\
$35-40$ & Dolomite, tan to gray, weathered; goethite; and quartz crystals \\
$40-50$ & Dolomite, tan to gray; goethite \\
$50-103$ & Dolomite, light gray to white, occasional iron oxide staining & Water at 250 feet \\
$103-110$ & & \\
$110-170$ & Dolomite, light gray to white, occasional iron oxide staining \\
$170-260$ & Dolomite, gray with blue banding, occasional iron oxide staining \\
$260-270$ & Dolomite, gray with thicker blue banding \\
$270-275$ & Dolomite, gray with thinner blue banding, \\
$275-303$ & Dolomite, blue \\
\hline
\end{tabular}


Table 6. Geologic log for well CC-21, Malvern TCE Site, Chester County, Pennsylvania

[Well drilled March 12-16, 1996.]

\begin{tabular}{cl}
\hline $\begin{array}{c}\text { Depth below } \\
\text { land surface (feet) }\end{array}$ & \multicolumn{1}{c}{ Lithologic description } \\
\hline $0-23$ & Clay, white to gray; soil \\
$23-35$ & Clay, orange to tan \\
$35-48$ & Clay, orange to brown; weathered dolomite fragments \\
$48-60$ & Clay, orange to brown and gray to tan; weathered dolomite fragments \\
$60-65$ & Dolomite, weathered \\
$65-70$ & Dolomite, gray to brown, weathered \\
$70-80$ & Dolomite, gray to brown, weathered; and clay, orange to white \\
$80-105$ & Dolomite, gray to brown, weathered, with some clay \\
$105-110$ & \\
$110-125$ & Dolomite, gray to brown, weathered with some clay \\
$125-135$ & Dolomite, gray to brown, weathered \\
$135-170$ & Dolomite, gray \\
$170-185$ & Dolomite, gray and brown with blue banding, weathered \\
\hline
\end{tabular}

Table 7. Geologic log for well CC-22, Malvern TCE Site, Chester County, Pennsylvania [Well drilled February 20-26, 1996; XRD, X-ray diffraction analysis]

\begin{tabular}{|c|c|c|}
\hline $\begin{array}{l}\text { Depth below } \\
\text { land surface (feet) }\end{array}$ & Lithologic description & Comments \\
\hline $0-13$ & Clay; soil & \\
\hline $13-23$ & Clay, white; kaolinite & $\begin{array}{l}\text { XRD analysis of clay } \\
\text { showed kaolinite, } \\
\text { muscovite, and quartz }\end{array}$ \\
\hline $23-33$ & Clay, white to tan & \\
\hline $33-43$ & Clay, white to tan and brown & \\
\hline $43-53$ & Clay, white, tan, and gray-brown & \\
\hline $53-63$ & Clay, white, tan, orange, and gray-brown & \\
\hline $63-80$ & Clay, tan and gray-brown & \\
\hline $80-90$ & Dolomite, gray, slightly weathered; and clay, orange-brown & \\
\hline $90-95$ & Dolomite, gray, slightly weathered; and clay, orange-brown & XRD confirmation of dolomite \\
\hline $95-100$ & $\begin{array}{l}\text { Dolomite, gray, slightly weathered; quartz crystals; and clay, orange- } \\
\text { brown }\end{array}$ & \\
\hline $100-105$ & Dolomite, gray, slightly weathered & \\
\hline $105-110$ & Dolomite, light gray to tan, slightly weathered & $\begin{array}{l}\text { Large fracture and water } \\
\text { at } 106 \text { feet }\end{array}$ \\
\hline $110-125$ & $\begin{array}{l}\text { Dolomite, light gray to tan, slightly weathered; quartz crystals; and } \\
\text { goethite }\end{array}$ & XRD confirmation of goethite \\
\hline $1125-165$ & Dolomite, light gray with blue veins; quartz crystals; and gothite & \\
\hline${ }^{1} 165-225$ & Dolomite, light gray to blue; quartz crystals; and gothite & \\
\hline $1225-303$ & Dolomite, blue; quartz crystals; and gothite & \\
\hline
\end{tabular}

${ }^{1}$ No returns during drilling. Samples obtained every 20 feet when borehole was blown clear with compressed air before next drill rod was added. Returns probably lodged in fracture at 106 feet below land surface. 
Table 8. Geologic log for well CC-23, Malvern TCE Site, Chester County, Pennsylvania

[Well drilled September 23-25, 1996.]

\begin{tabular}{|c|c|c|}
\hline $\begin{array}{c}\text { Depth below } \\
\text { land surface (feet) }\end{array}$ & Lithologic description & Comments \\
\hline $0-12$ & Clay, yellow and brown; soil & \\
\hline $12-16$ & Clay, gray & \\
\hline $16-23$ & Dolomite, gray, tan, and pink & \\
\hline $24-28$ & Dolomite, tan & \\
\hline $30-34$ & Dolomite, iron stained; clay; & \\
\hline $34-43$ & Clay, dark brown; very stained dolomite & \\
\hline $48-63$ & Dolomite, tan & \\
\hline $63-65$ & Dolomite, tan, pink, and brown & \\
\hline $65-70$ & Dolomite, tan, brown, and gray & \\
\hline $70-85$ & Dolomite, buff & \\
\hline $85-97$ & Dolomite, gray & \\
\hline $97-102$ & Dolomite, $\tan$ & Minor water at 100 feet \\
\hline $102-115$ & Dolomite, tan and gray & \\
\hline $115-122$ & Dolomite, tan to brownish gray & \\
\hline $122-137$ & Dolomite, tan, brown, and gray & \\
\hline $137-147$ & Dolomite, brown, tan, and gray & \\
\hline $147-152$ & Dolomite, tannish-gray and brown & \\
\hline $152-162$ & Dolomite, brown & \\
\hline $162-177$ & Dolomite, tan, gray, and brown & \\
\hline $177-182$ & Dolomite, tan and gray & \\
\hline $182-192$ & Dolomite, brown & \\
\hline $192-200$ & Dolomite, gray, tan, and brown & \\
\hline $200-206$ & Dolomite, tan and gray & \\
\hline $206-213$ & Dolomite, tan & \\
\hline $213-217$ & Dolomite, brown & \\
\hline $217-223$ & Dolomite, tan & \\
\hline $223-228$ & Dolomite, brown & \\
\hline $228-233$ & Dolomite, tan & \\
\hline $233-243$ & Dolomite, tan and brown & \\
\hline $243-249$ & Dolomite, brown and tan & \\
\hline $249-257$ & Dolomite, gray and tan & \\
\hline $257-263$ & Dolomite, brown and tan & \\
\hline $263-268$ & Dolomite, gray, tan & \\
\hline $268-272$ & Dolomite, gray, tan, and brown & \\
\hline $272-279$ & Dolomite, tan, brown, and gray & $\begin{array}{l}\text { Water ( } 10 \text { gallons per minute) } \\
\text { at } 272 \text { feet }\end{array}$ \\
\hline $279-282$ & $\begin{array}{l}\text { Clay, dark brown; clay, yellow-brown; silt, very fine; sand; and dolomite, } \\
\text { tan, in weathered blocks up to } 4 \text { inches }\end{array}$ & $\begin{array}{l}\text { Large fracture and water } \\
\text { (200 gallons per minute) } \\
\text { at } 279-282 \text { feet }\end{array}$ \\
\hline
\end{tabular}




\section{APPENDIX 3. WELL-CONSTRUCTION DIAGRAMS}




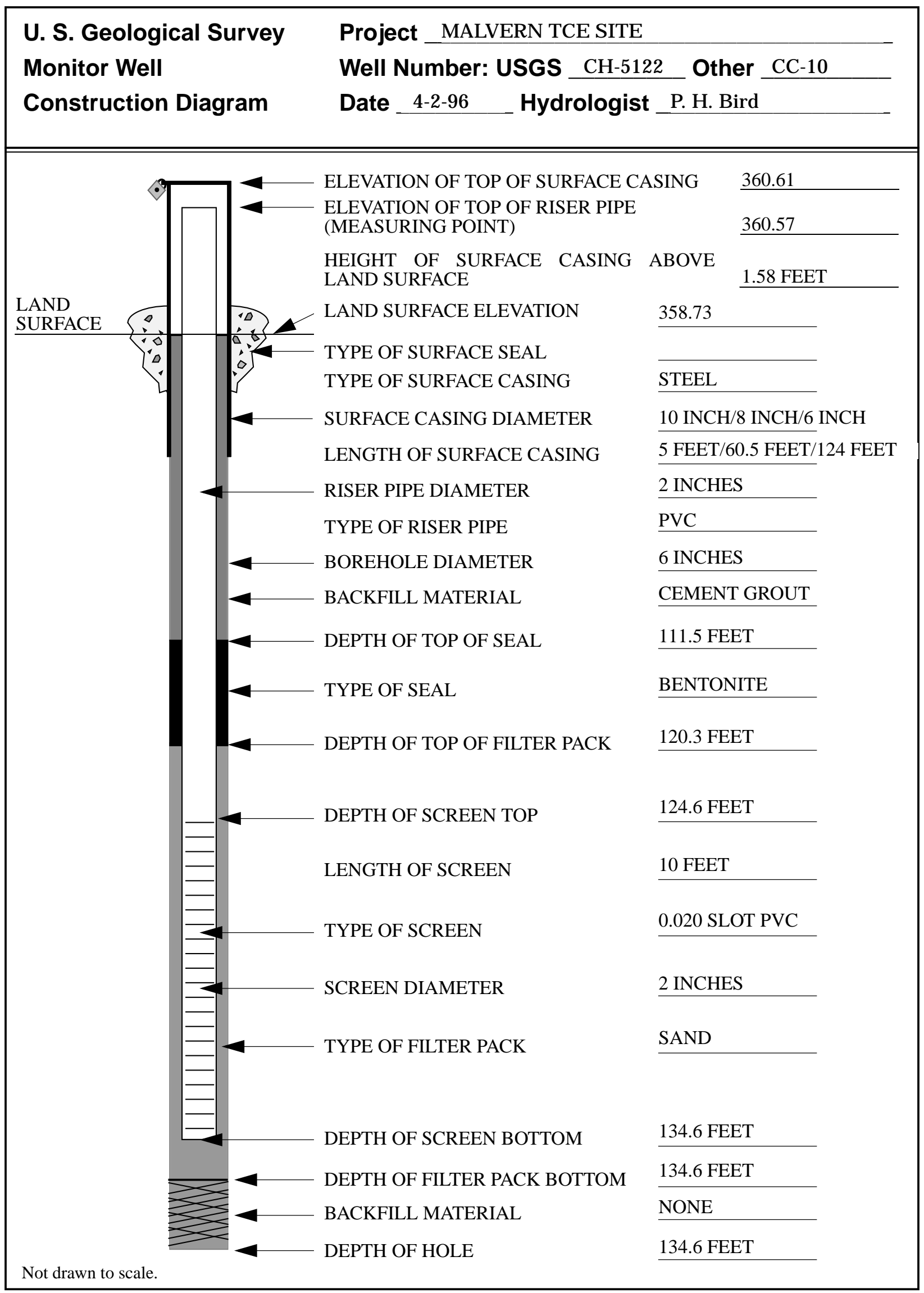




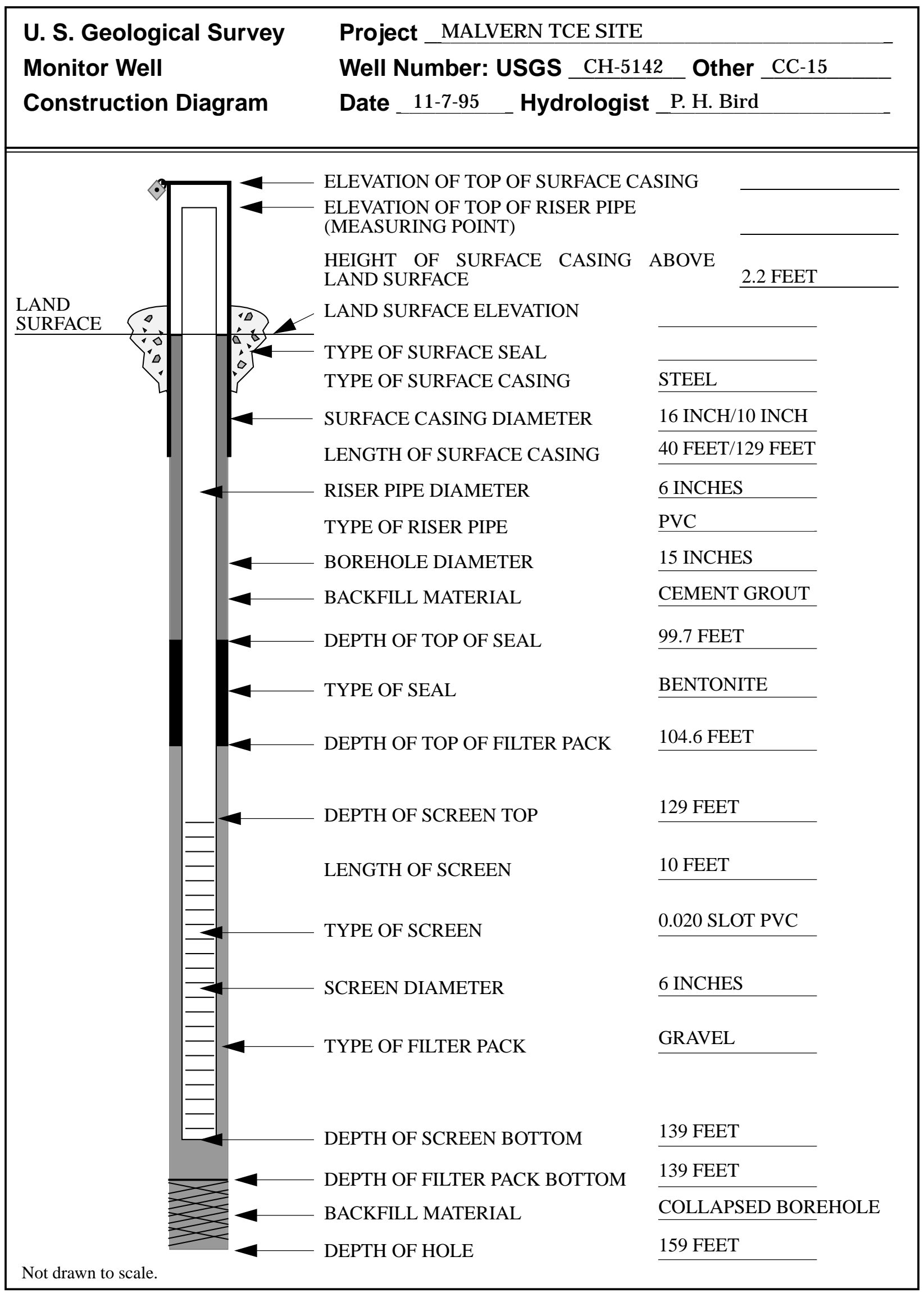




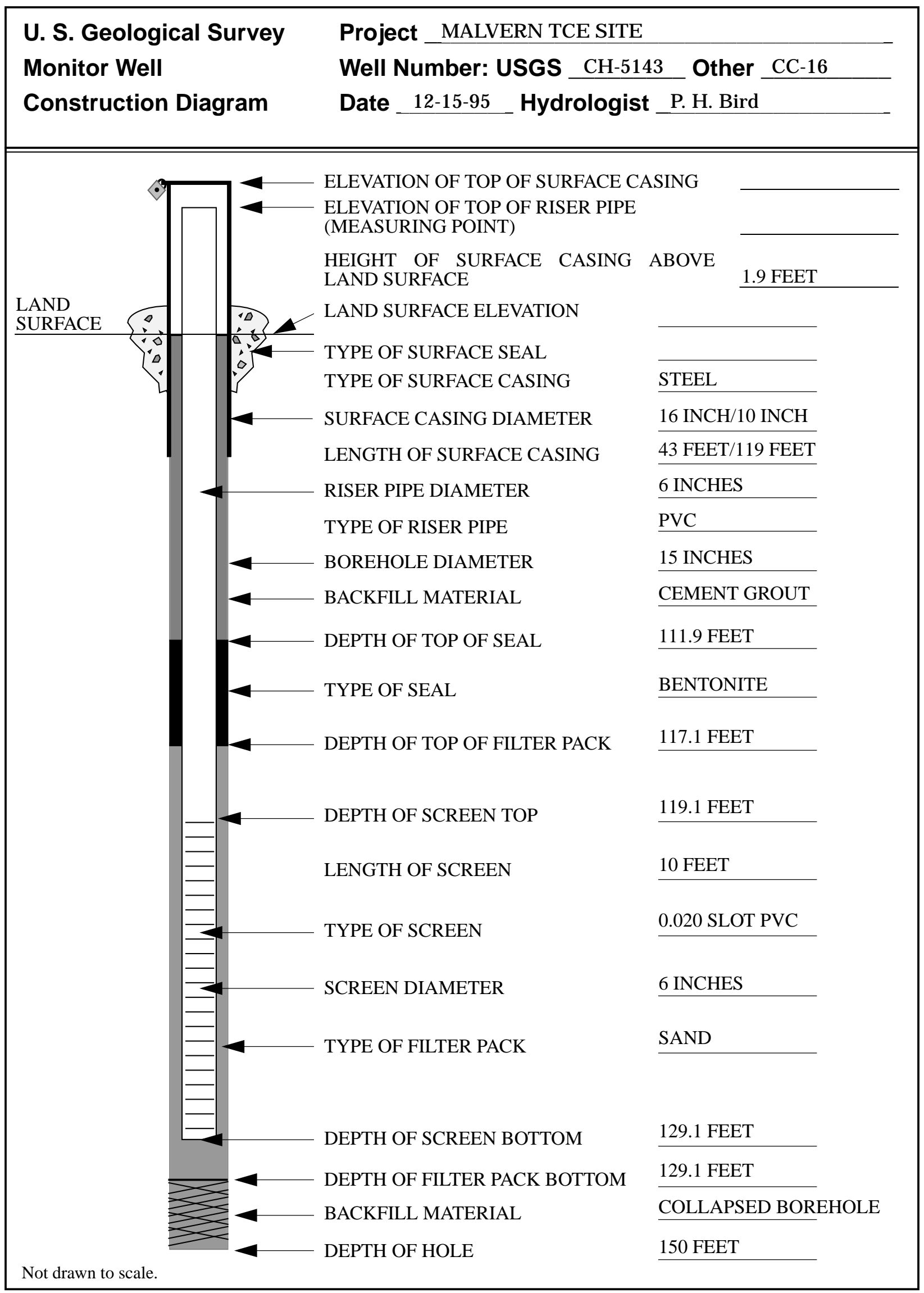




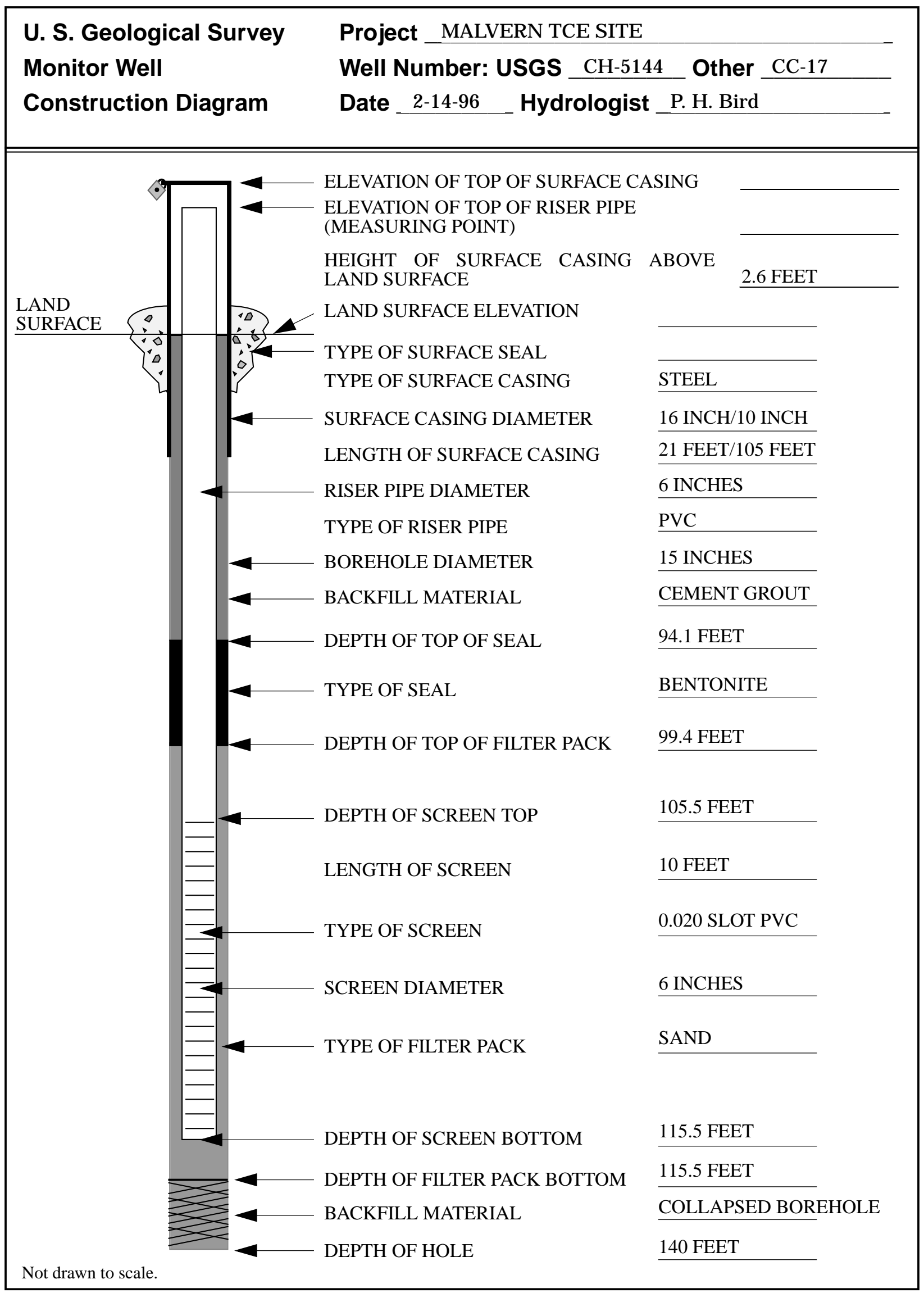




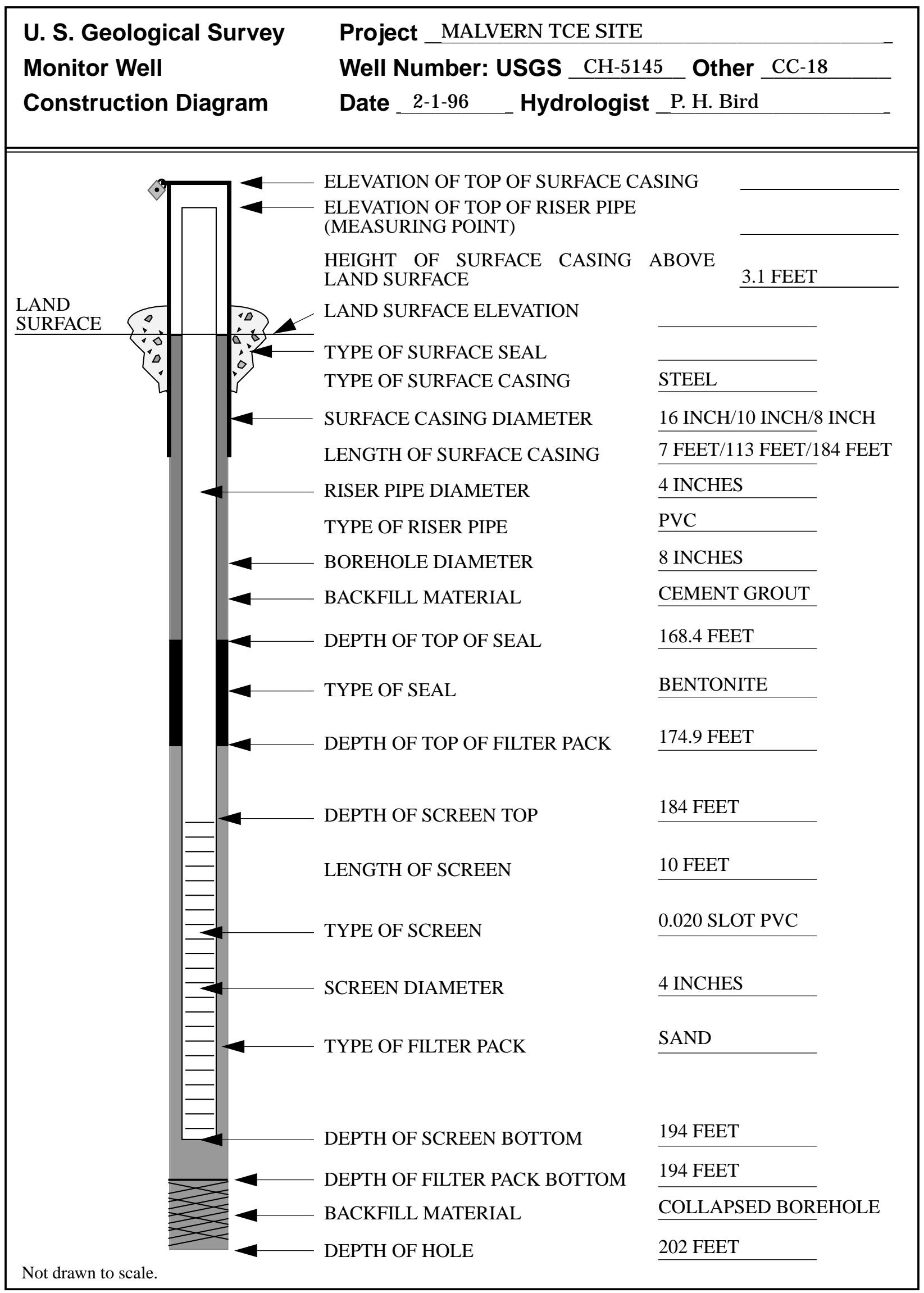




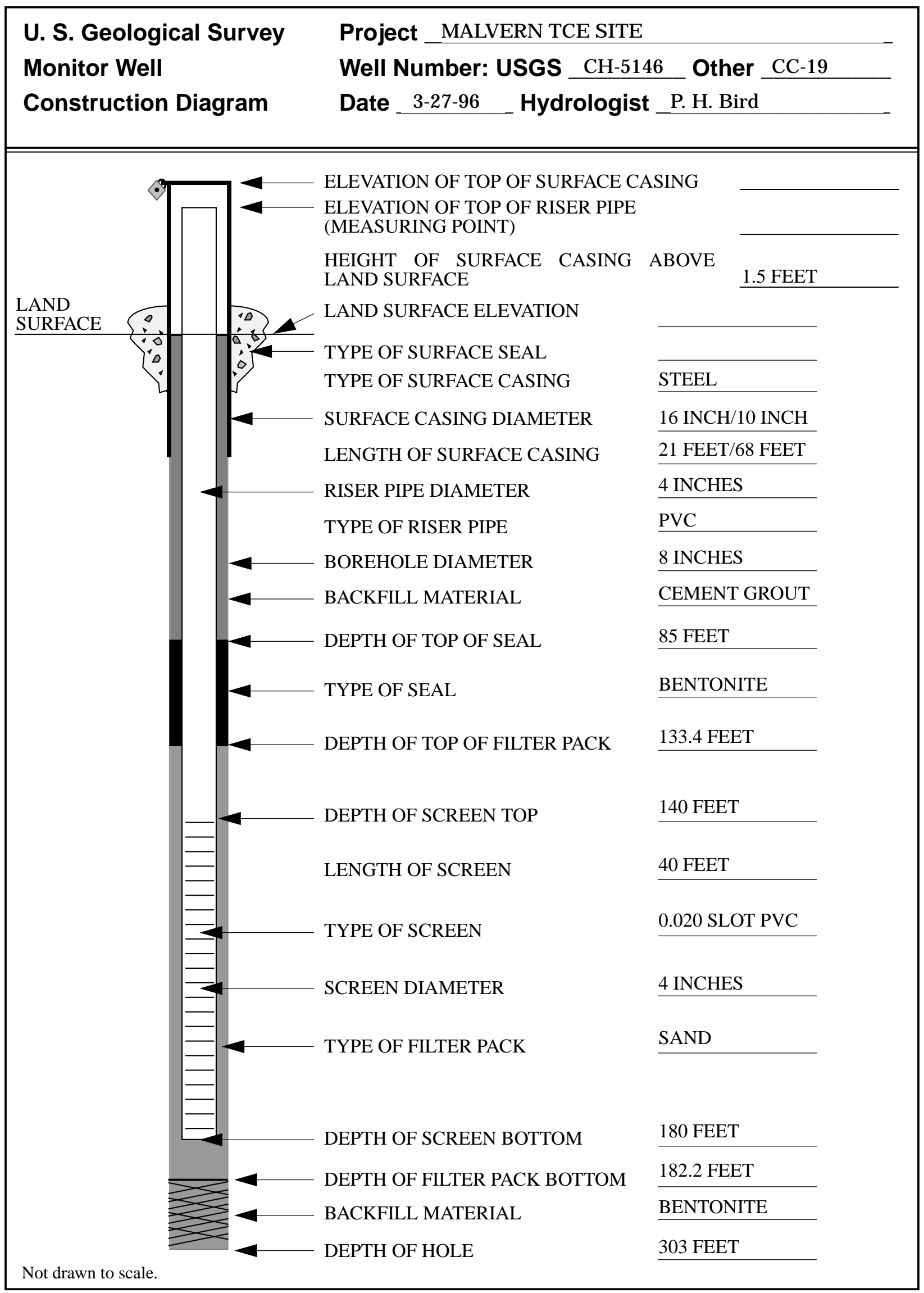




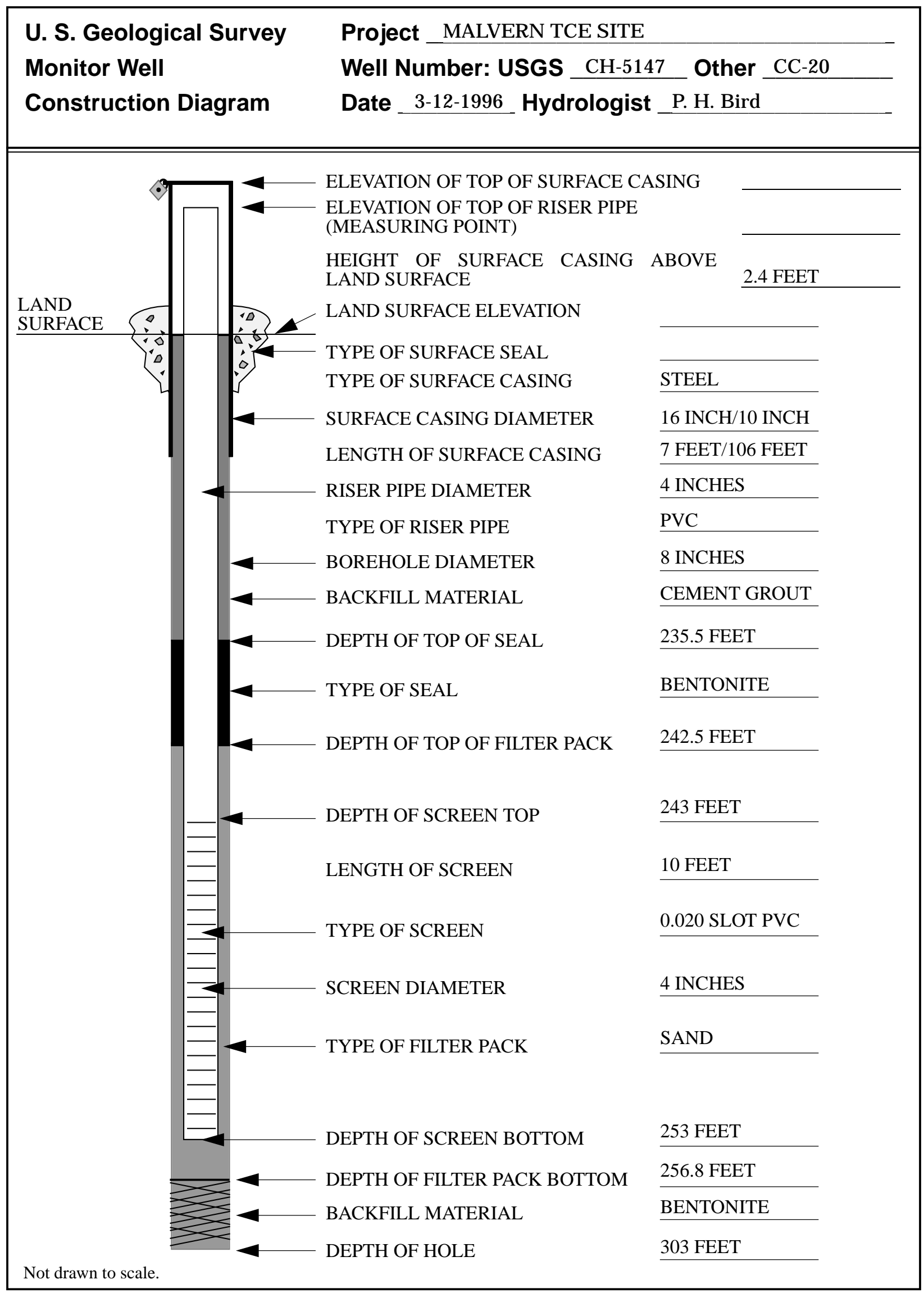




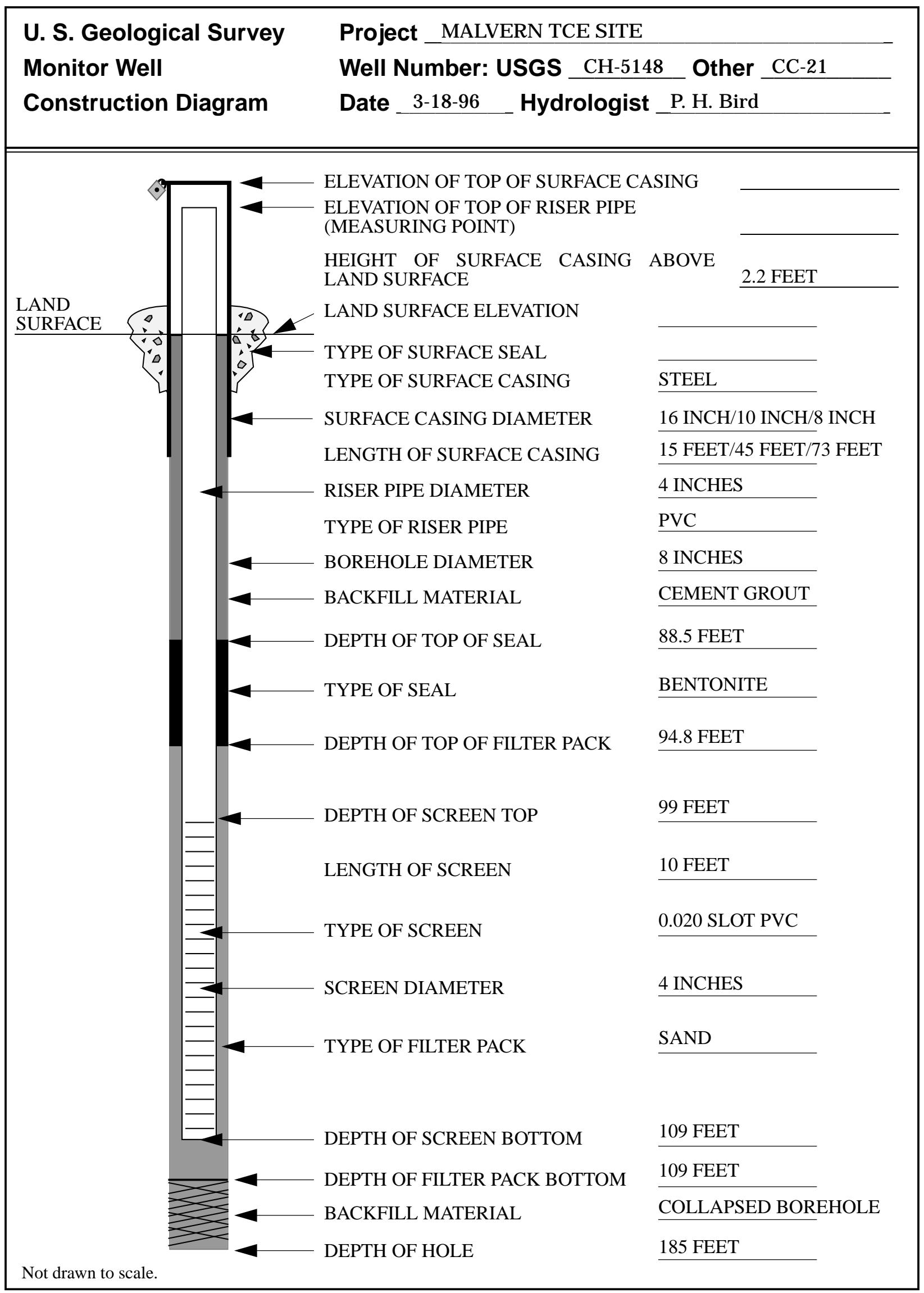




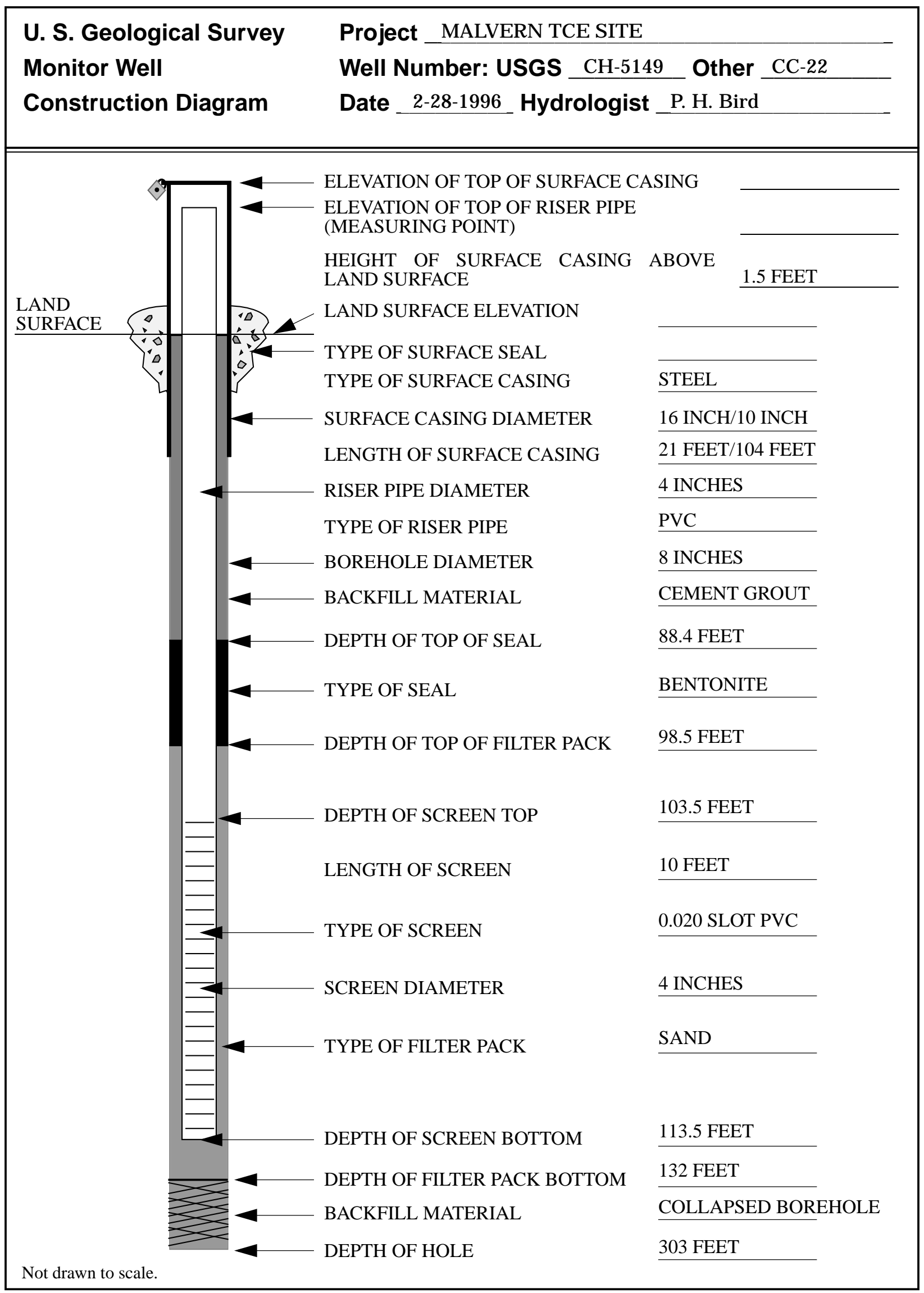




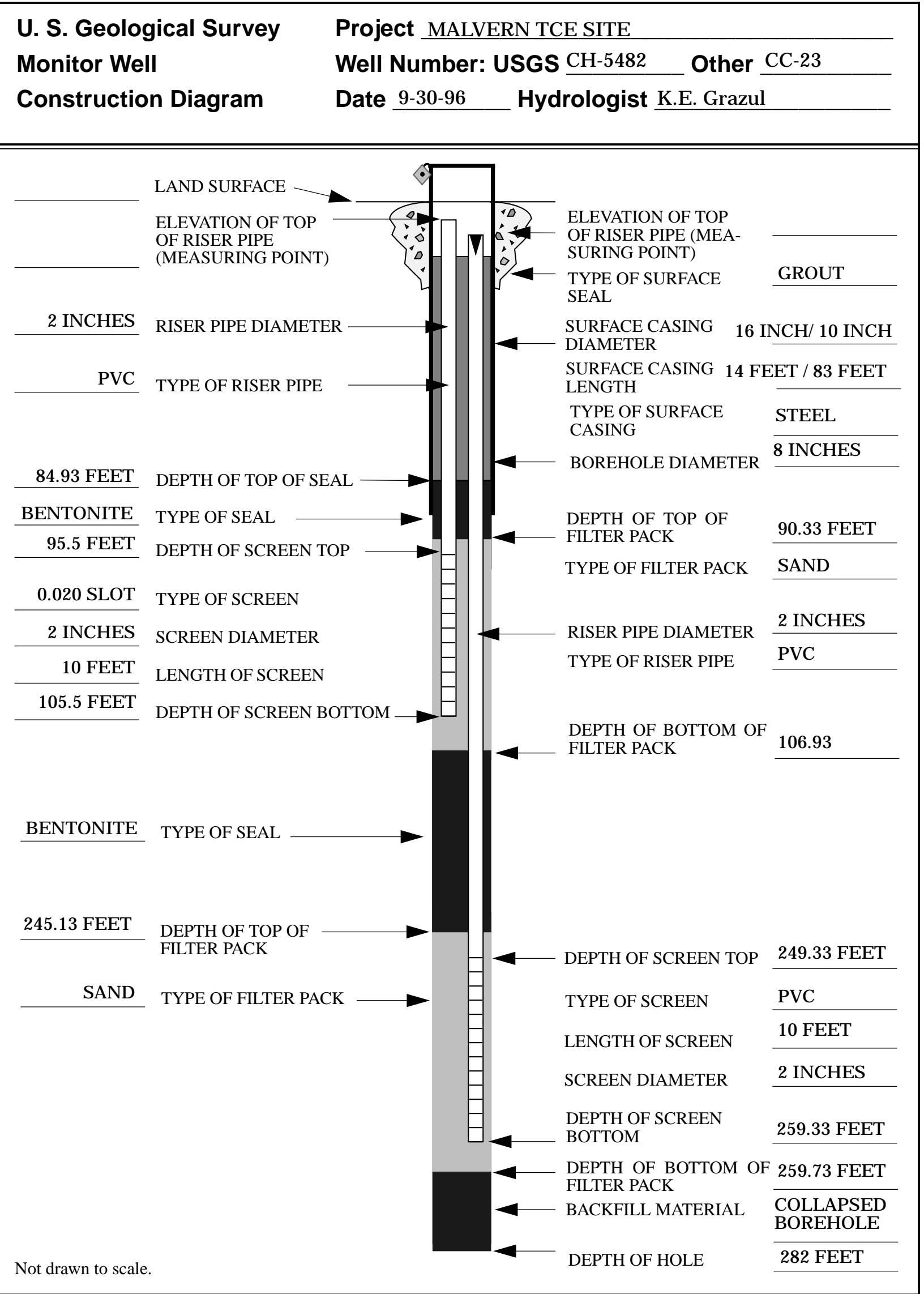




\section{APPENDIX 4. GRAPHS OF DRAWDOWN AND RECOVERY MEASURED DURING AQUIFER TESTS}




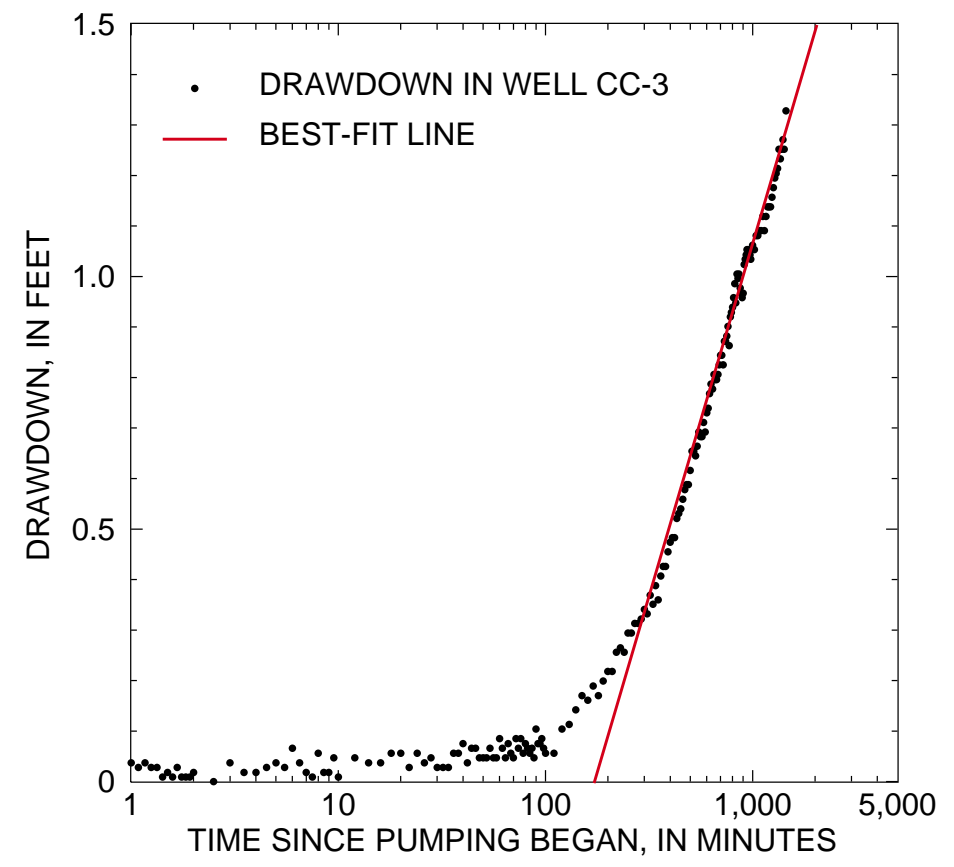

Figure 1. Relation between drawdown in well CC-3 and time for aquifer test of well CC-19, May 21-22, 1996, Malvern TCE Site, Chester County, Pennsylvania.

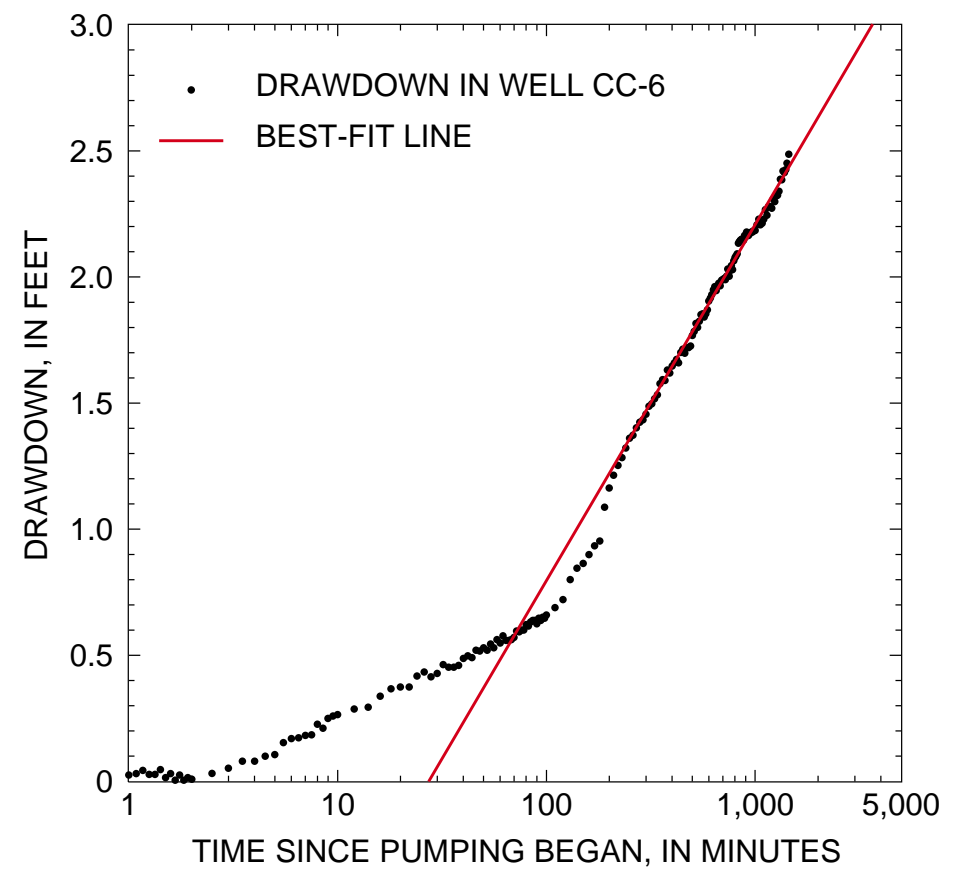

Figure 2. Relation between drawdown in well CC- 6 and time for aquifer test of well CC-19, May 21-22, 1996, Malvern TCE Site, Chester County, Pennsylvania. 


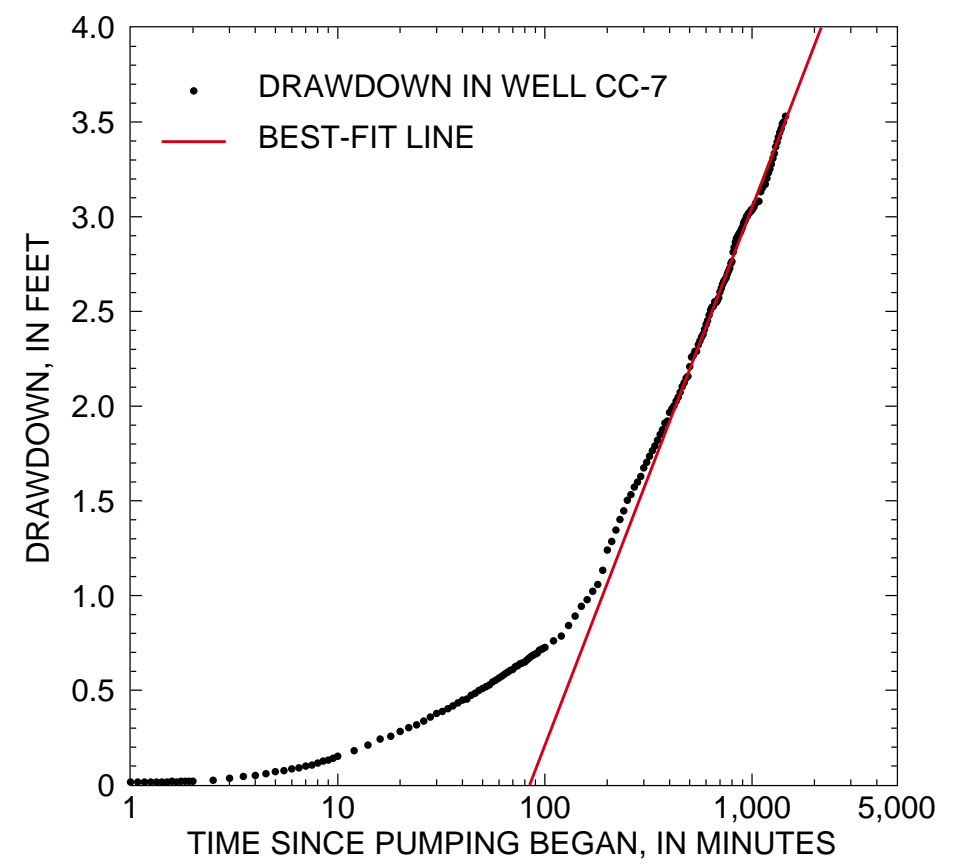

Figure 3. Relation between drawdown in well CC-7 and time for aquifer test of well CC-19, May 21-22, 1996, Malvern TCE Site, Chester County, Pennsylvania.

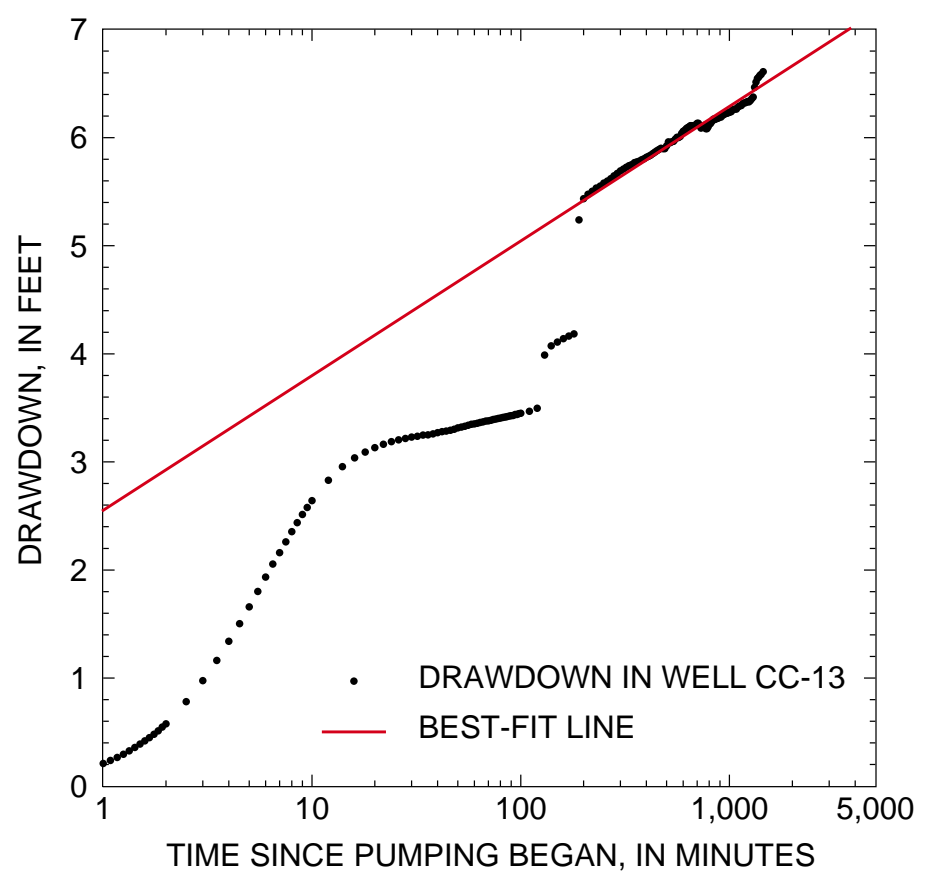

Figure 4. Relation between drawdown in well CC-13 and time for aquifer test of well CC-19, May 21-22, 1996, Malvern TCE Site, Chester County, Pennsylvania. 


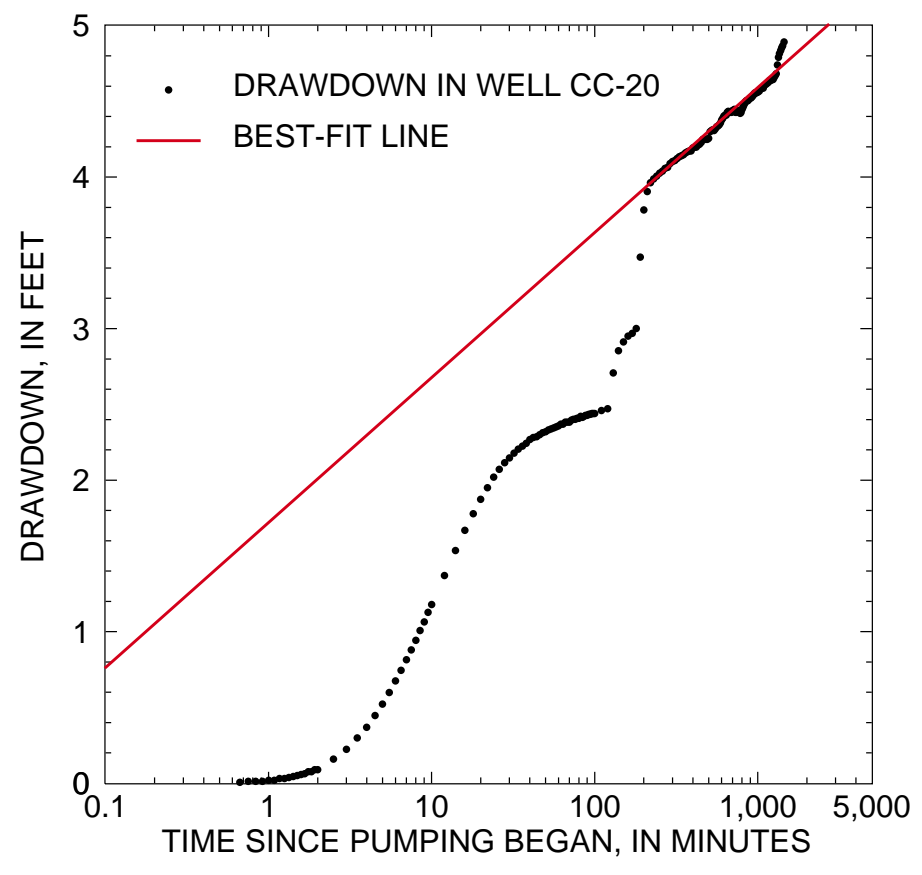

Figure 5. Relation between drawdown in well CC-20 and time for aquifer test of well CC-19, May 21-22, 1996, Malvern TCE Site, Chester County, Pennsylvania.

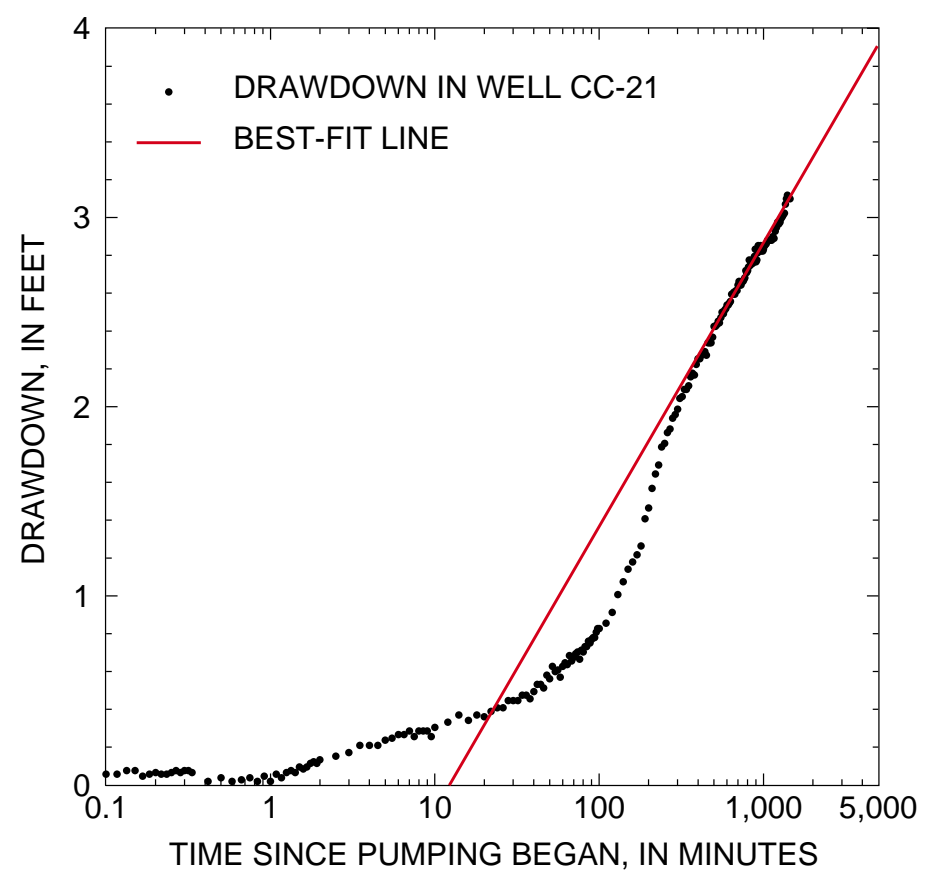

Figure 6. Relation between drawdown in well CC-21 and time for aquifer test of well CC-19, May 21-22, 1996, Malvern TCE Site, Chester County, Pennsylvania. 


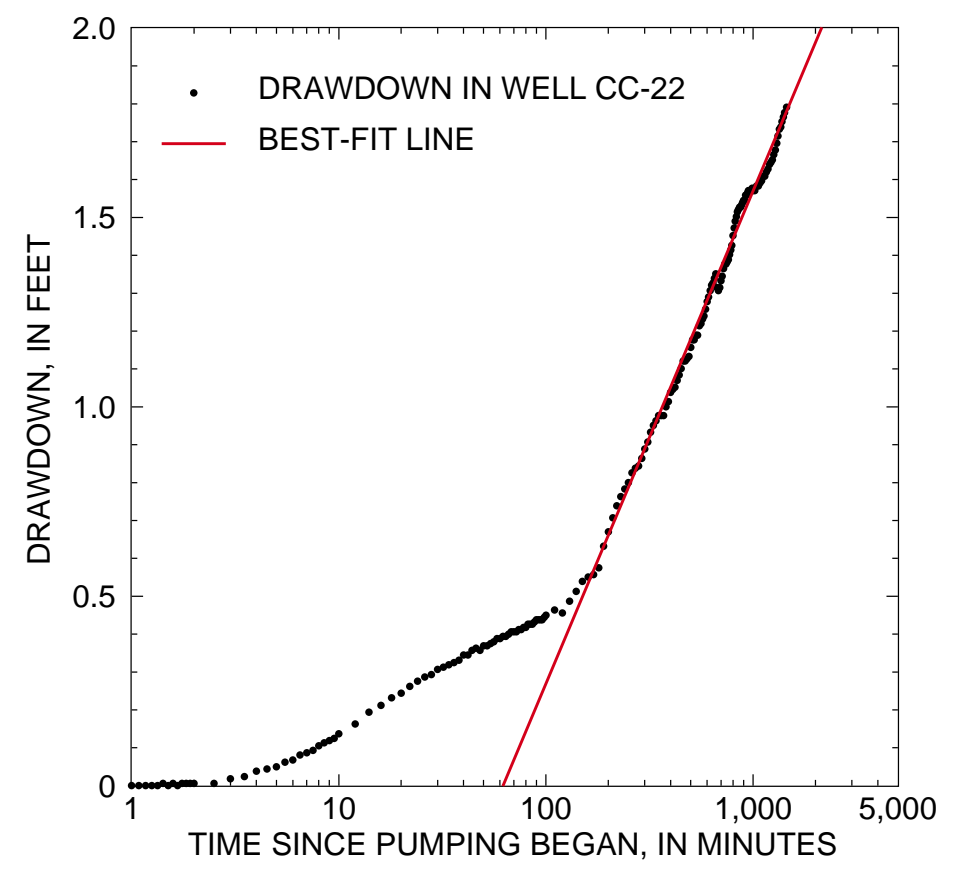

Figure 7. Relation between drawdown in well CC-22 and time for aquifer test of well CC-19, May 21-22, 1996, Malvern TCE Site, Chester County, Pennsylvania.

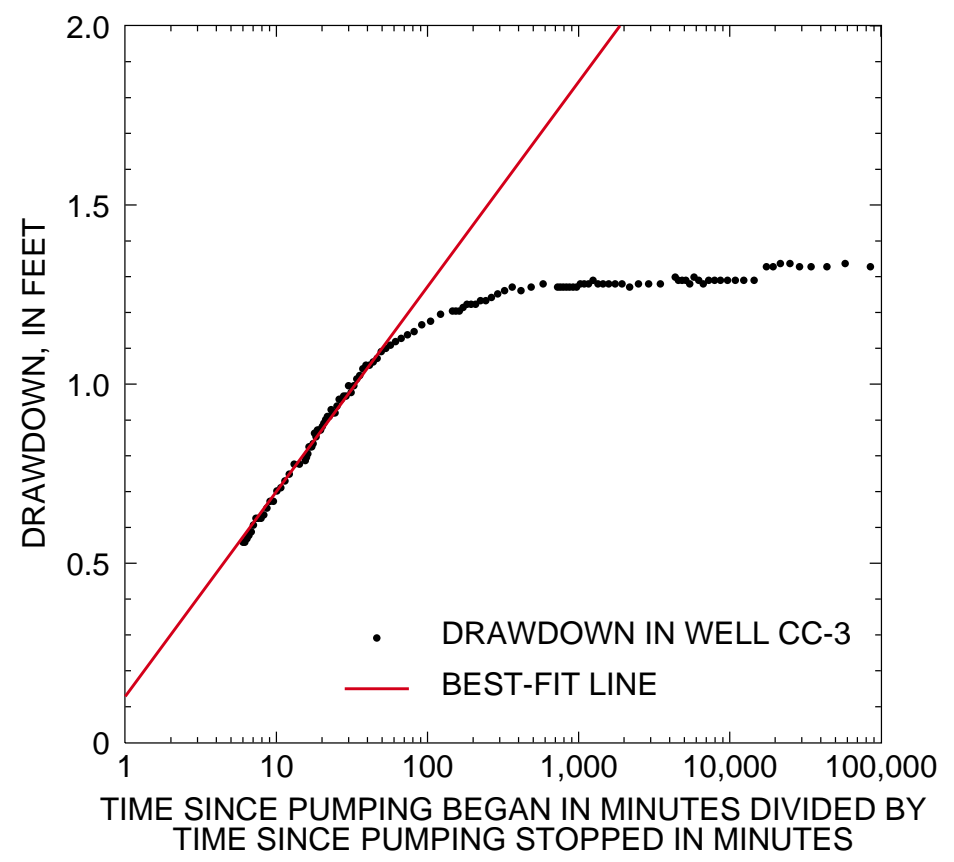

Figure 8. Relation between drawdown in well CC-3 and time for recovery phase of aquifer test of well CC-19, May 22, 1996, Malvern TCE Site, Chester County, Pennsylvania. 


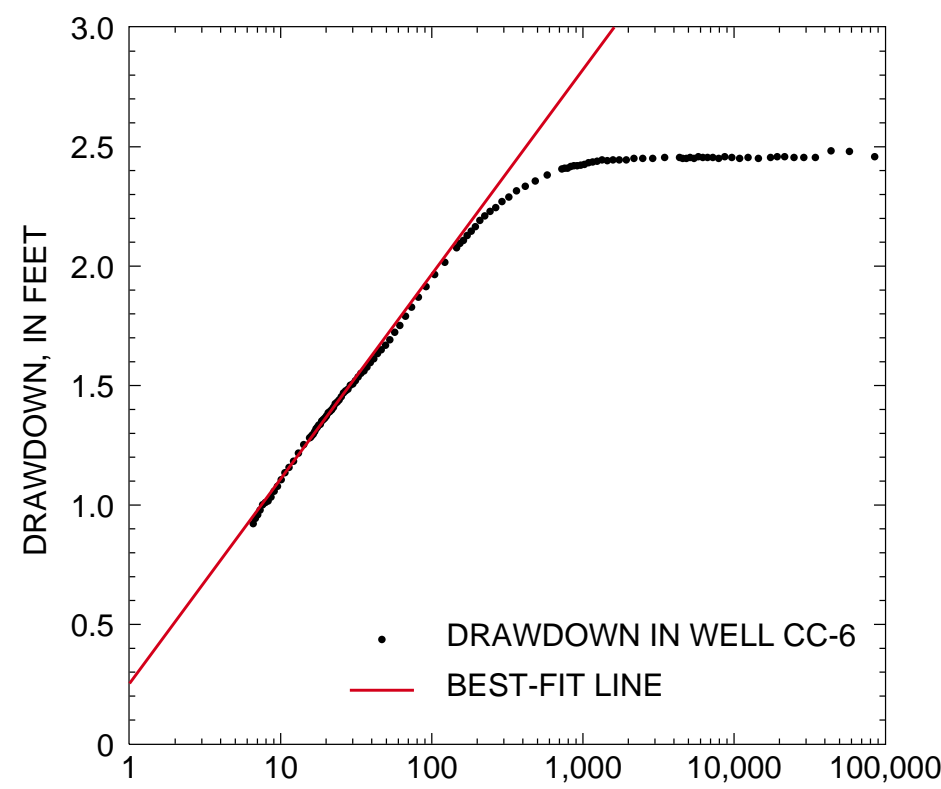

TIME SINCE PUMPING BEGAN IN MINUTES DIVIDED BY TIME SINCE PUMPING STOPPED IN MINUTES

Figure 9. Relation between drawdown in well CC-6 and time for recovery phase of aquifer test of well CC-19, May 22, 1996, Malvern TCE Site, Chester County, Pennsylvania.

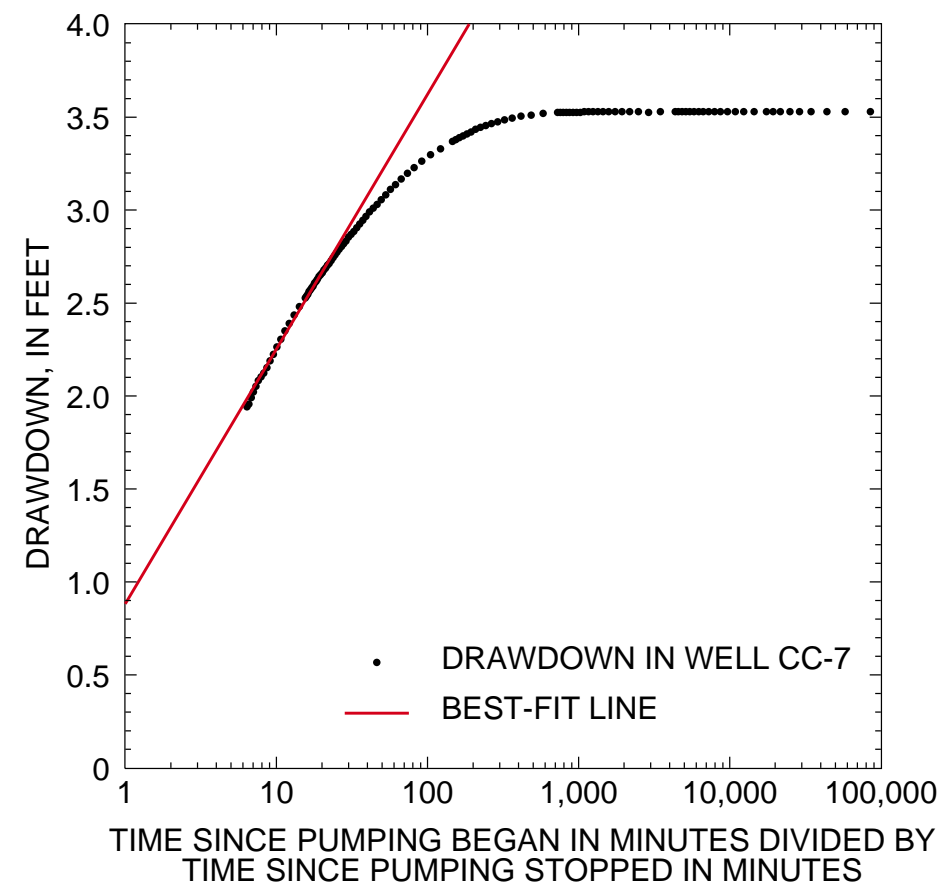

Figure 10. Relation between drawdown in well CC-7 and time for recovery phase of aquifer test of well CC-19, May 22, 1996, Malvern TCE Site, Chester County, Pennsylvania. 


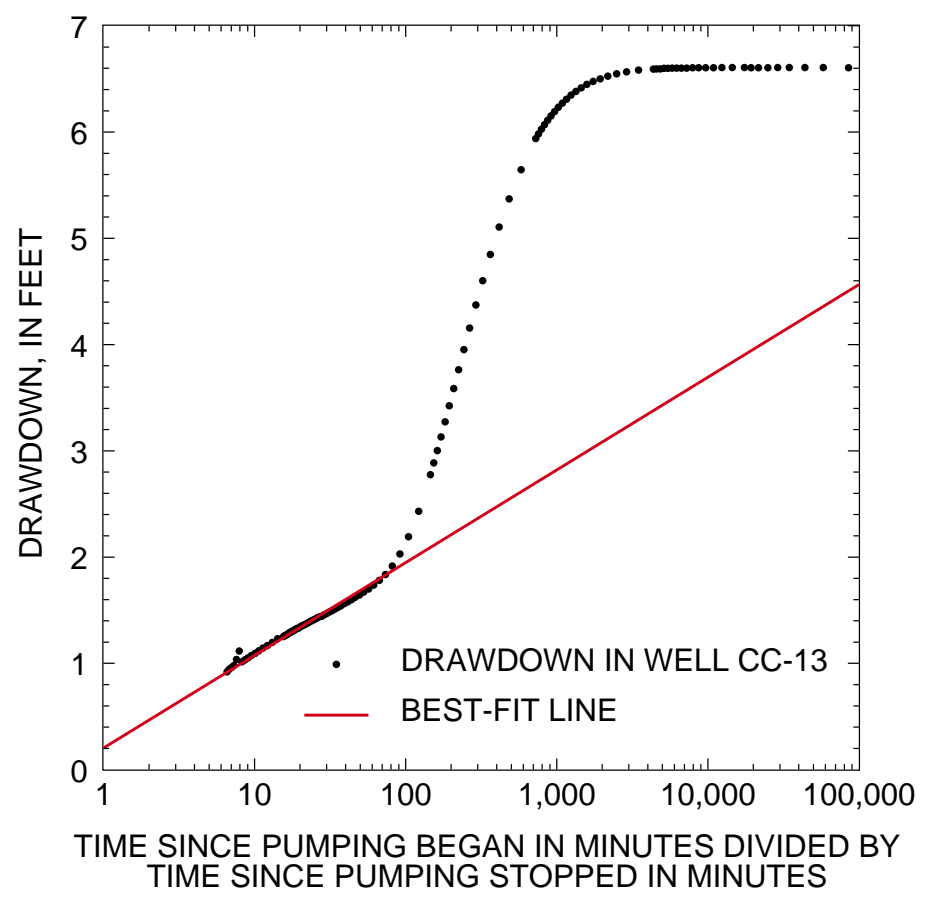

Figure 11. Relation between drawdown in well CC-13 and time for recovery phase of aquifer test of well CC-19, May 22, 1996, Malvern TCE Site, Chester County, Pennsylvania.

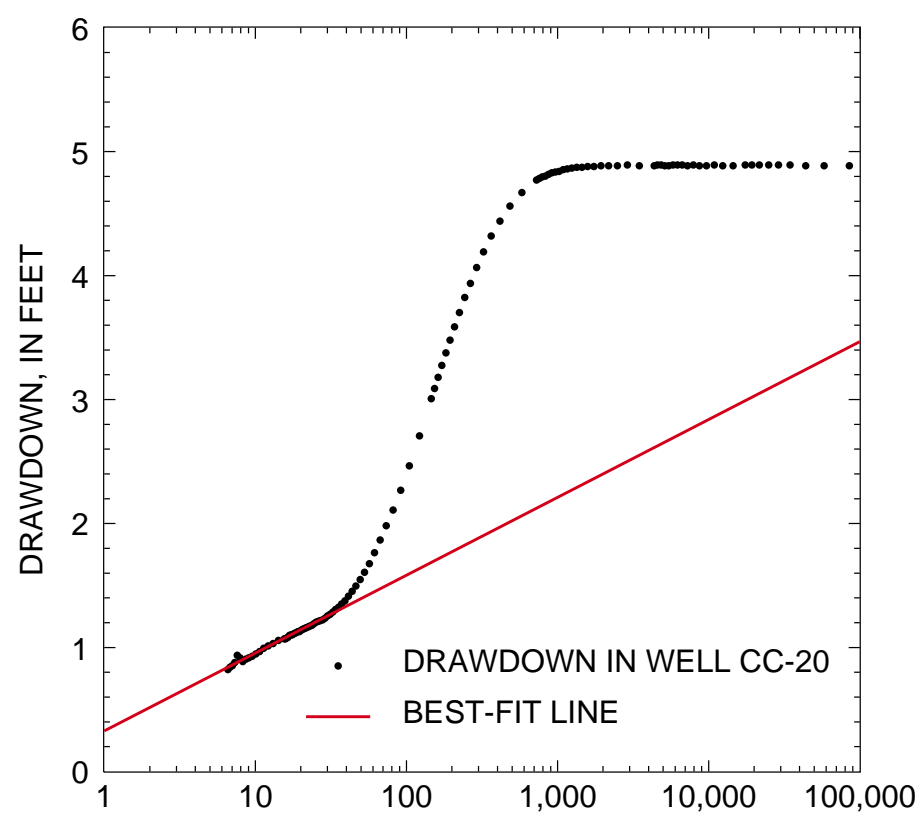

TIME SINCE PUMPING BEGAN IN MINUTES DIVIDED BY TIME SINCE PUMPING STOPPED IN MINUTES

Figure 12. Relation between drawdown in well CC-20 and time for recovery phase of aquifer test of well CC-19, May 22, 1996,

Malvern TCE Site, Chester County, Pennsylvania. 


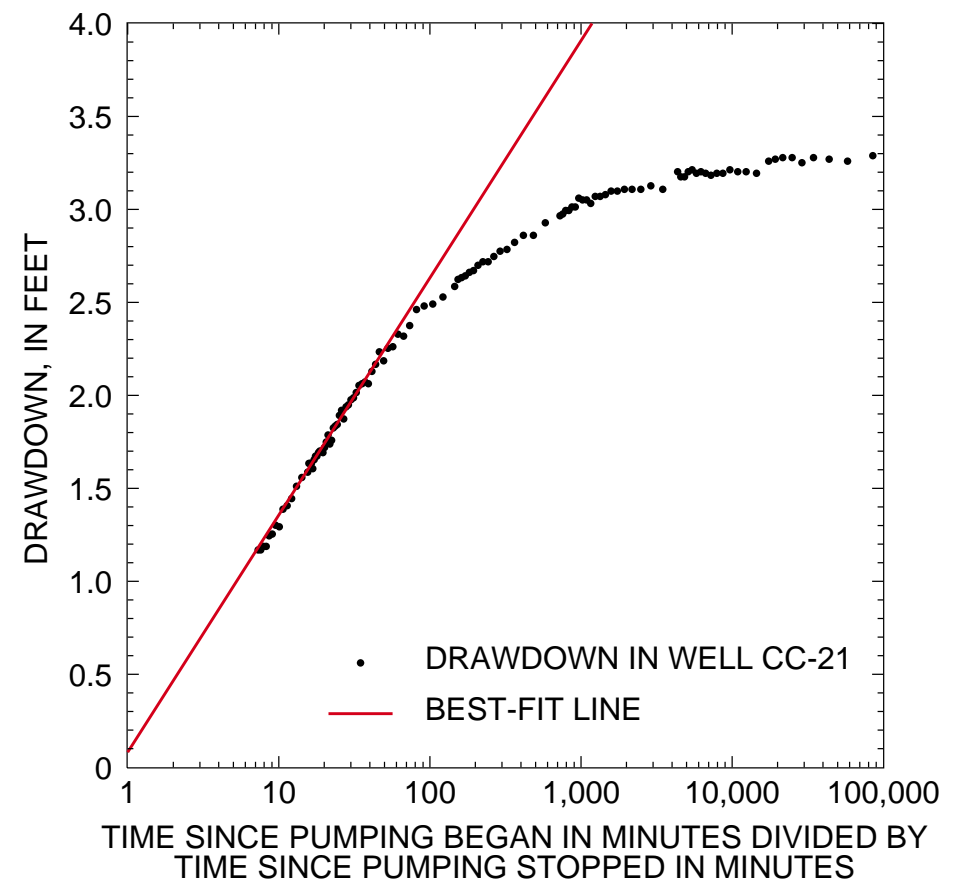

Figure 13. Relation between drawdown in well CC-21 and time for recovery phase of aquifer test of well CC-19, May 22, 1996, Malvern TCE Site, Chester County, Pennsylvania.

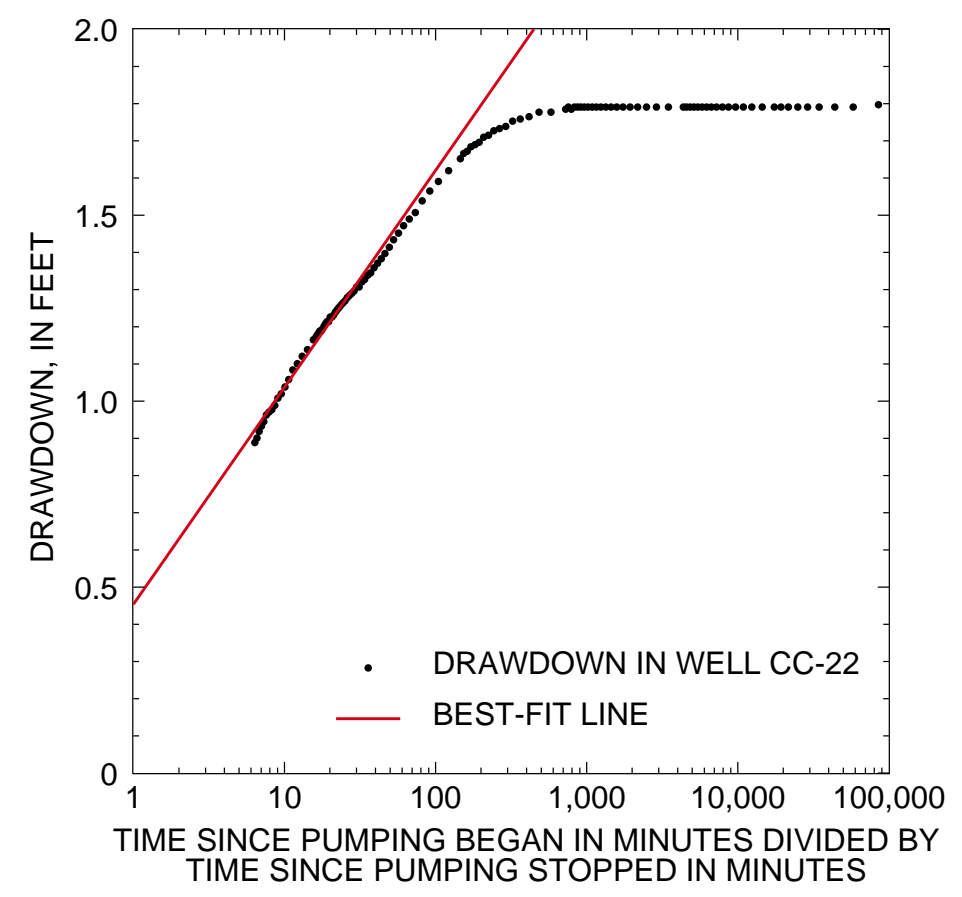

Figure 14. Relation between drawdown in well CC-22 and time for recovery phase of aquifer test of well CC-19, May 22, 1996,

Malvern TCE Site, Chester County, Pennsylvania. 


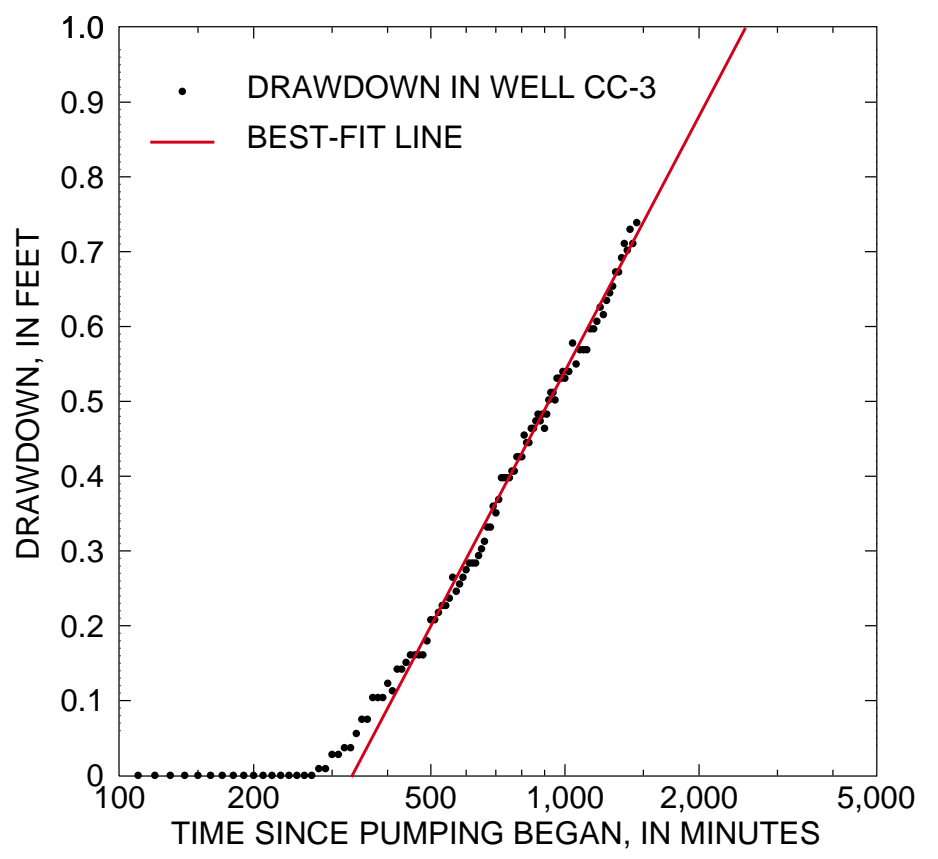

Figure 15. Relation between drawdown in well CC-3 and time for aquifer test of well CC-21, May 23-24, 1996, Malvern TCE Site, Chester County, Pennsylvania.

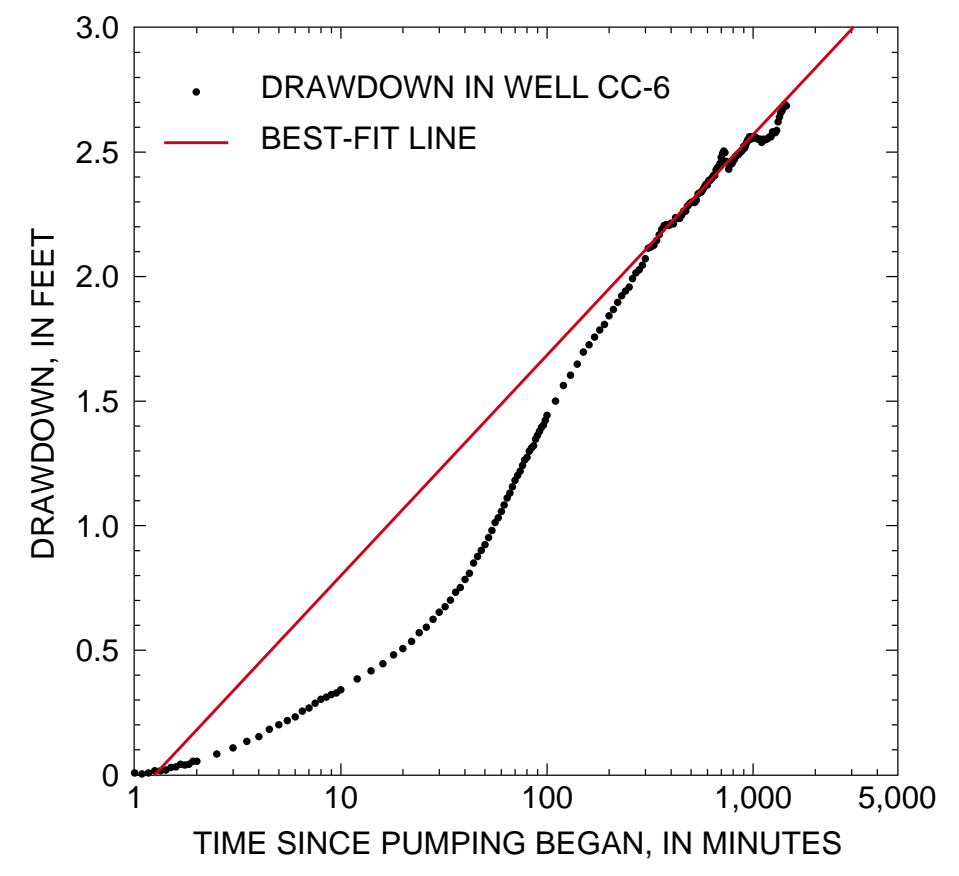

Figure 16. Relation between drawdown in well CC-6 and time for aquifer test of well CC-21, May 23-24, 1996, Malvern TCE Site, Chester County, Pennsylvania. 


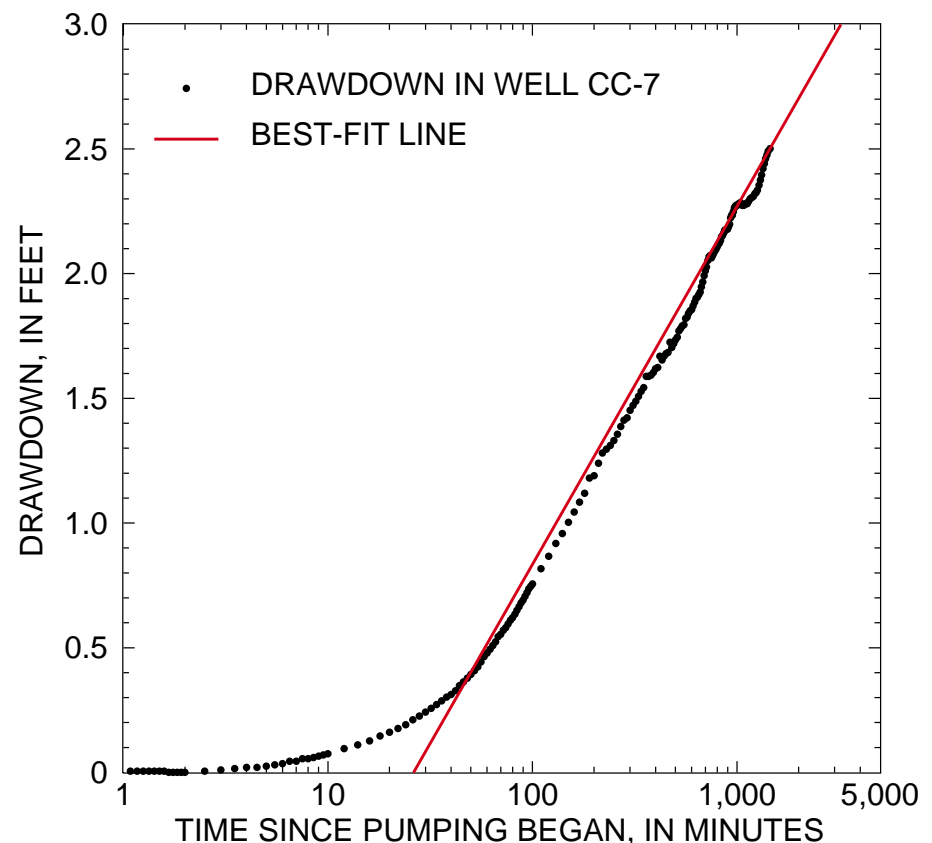

Figure 17. Relation between drawdown in well CC-7 and time for aquifer test of well CC-21, May 23-24, 1996, Malvern TCE Site, Chester County, Pennsylvania.

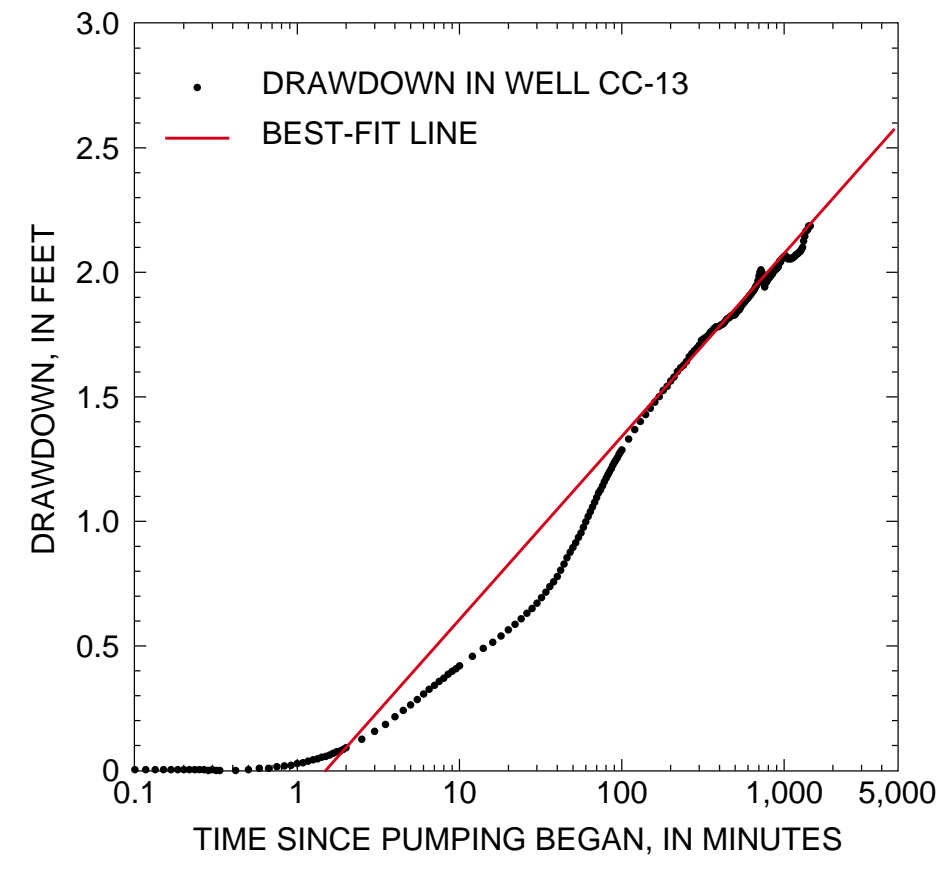

Figure 18. Relation between drawdown in well CC-13 and time for aquifer test of well CC-21, May 23-24, 1996, Malvern TCE Site, Chester County, Pennsylvania. 


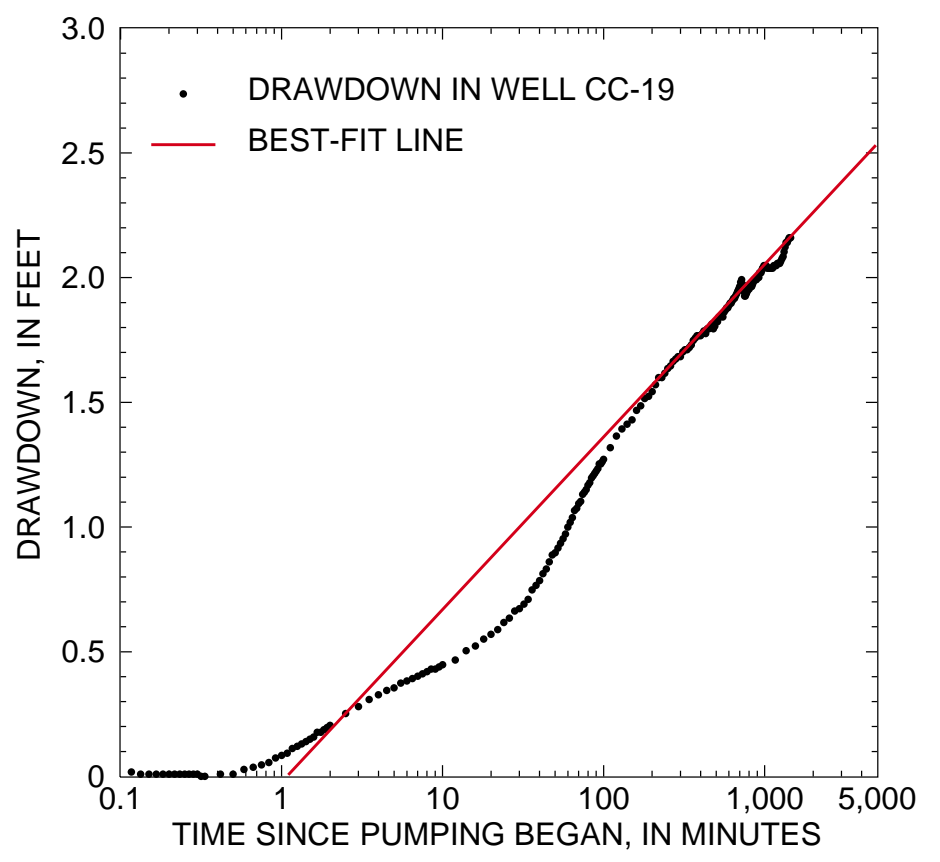

Figure 19. Relation between drawdown in well CC-19 and time for aquifer test of well CC-21, May 23-24, 1996, Malvern TCE Site, Chester County, Pennsylvania.

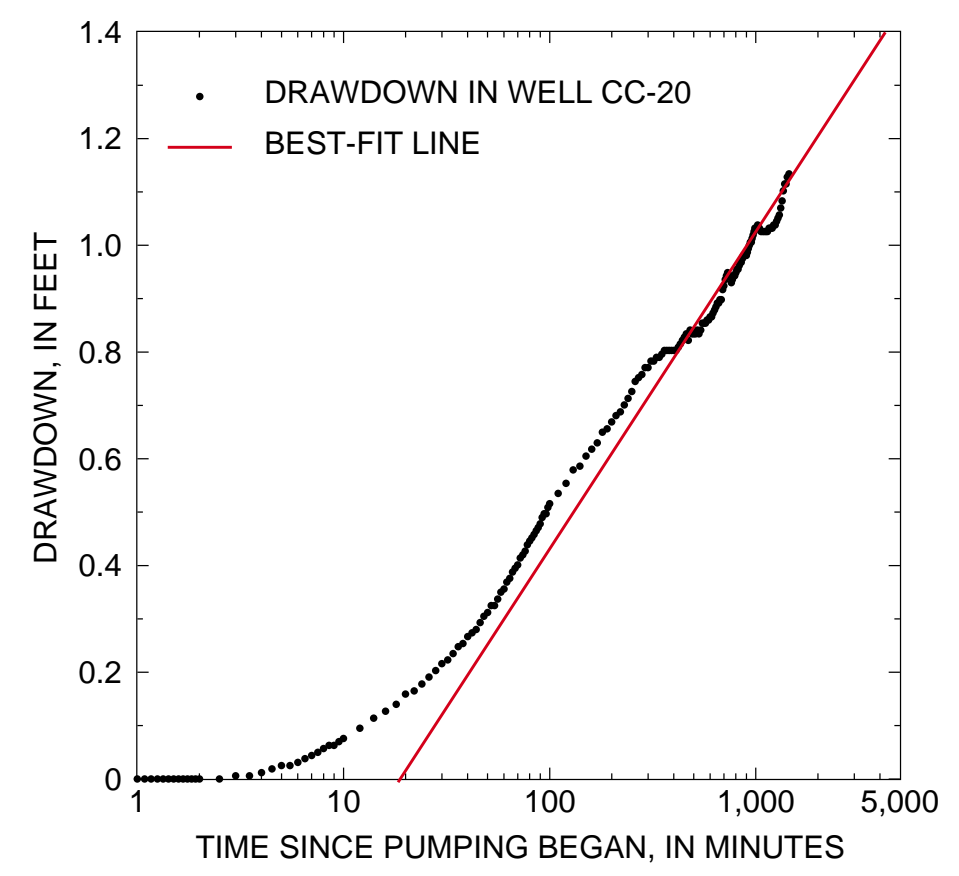

Figure 20. Relation between drawdown in well CC-20 and time for aquifer test of well CC-21, May 23-24, 1996, Malvern TCE Site, Chester County, Pennsylvania. 


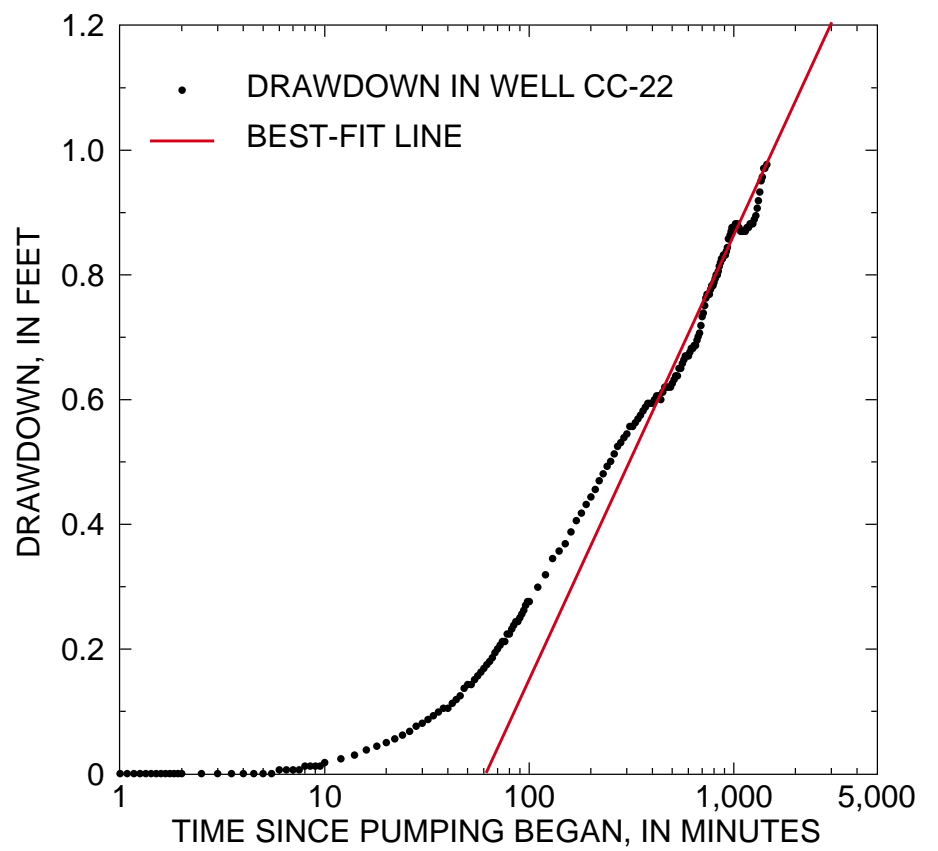

Figure 21. Relation between drawdown in well CC-22 and time for aquifer test of well CC-21, May 23-24, 1996, Malvern TCE Site, Chester County, Pennsylvania.

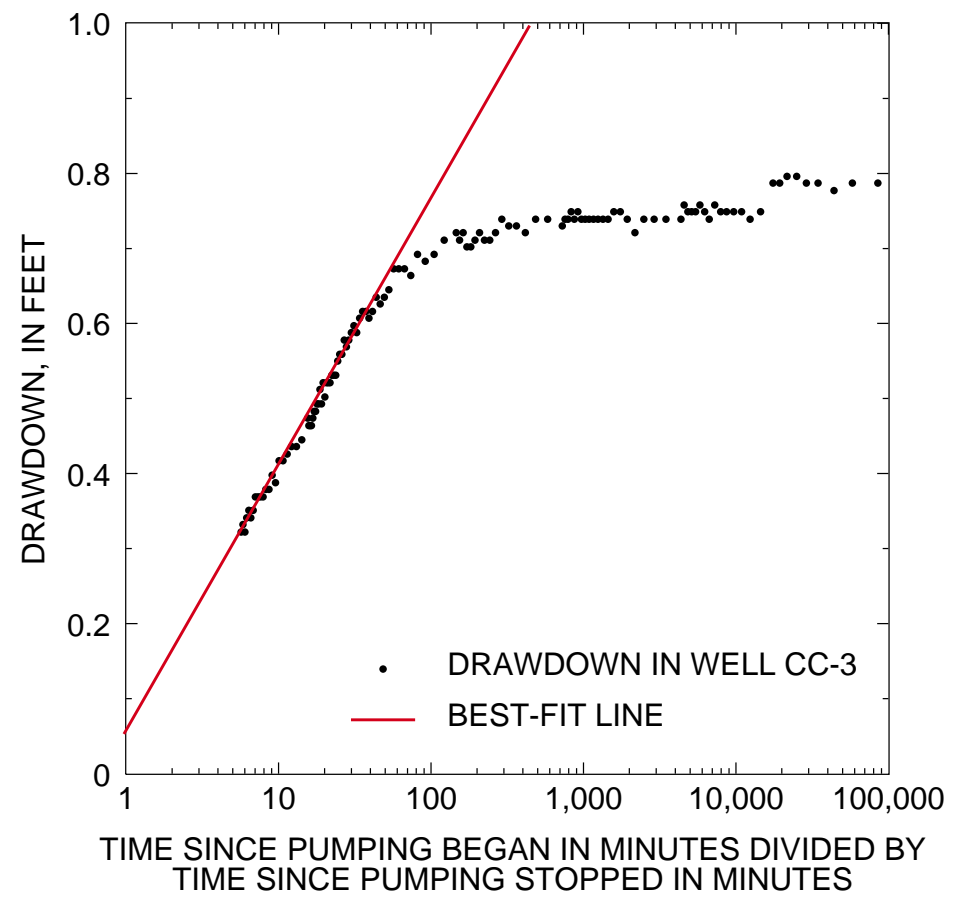

Figure 22. Relation between drawdown in well CC-3 and time for recovery phase of aquifer test of well CC-21, May 24, 1996, Malvern TCE Site, Chester County, Pennsylvania. 


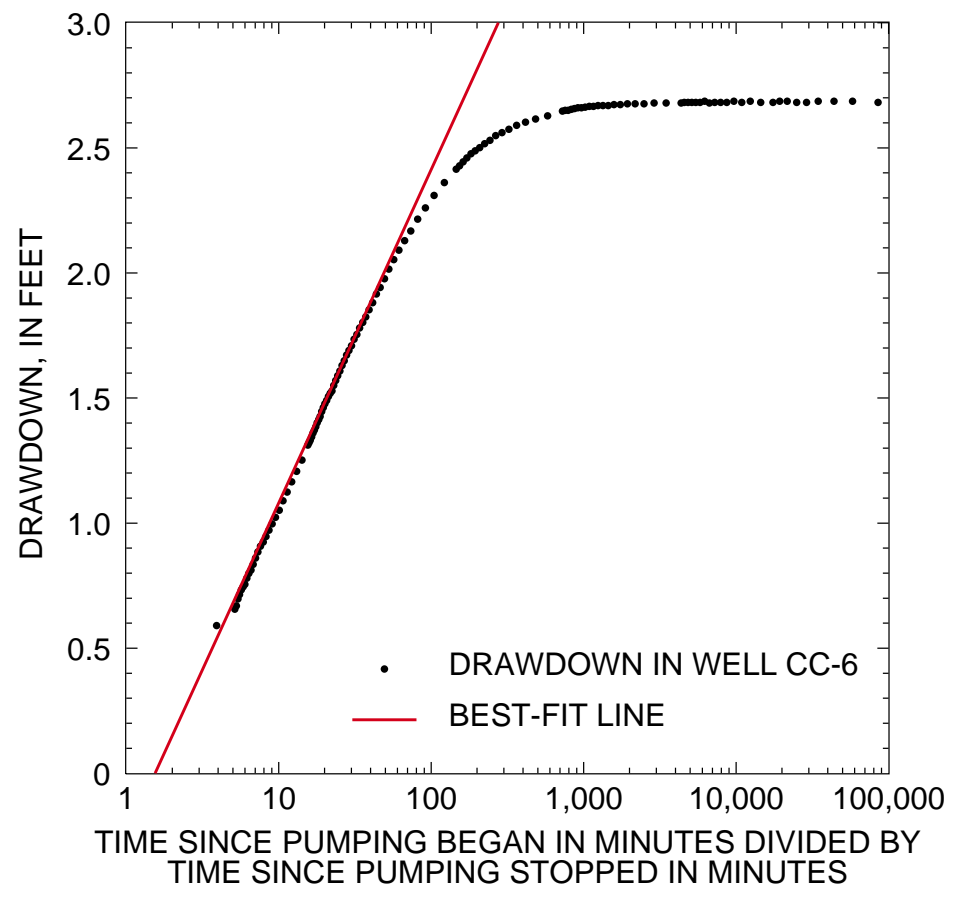

Figure 23. Relation between drawdown in well CC- 6 and time for recovery phase of aquifer test of well CC-21, May 24, 1996, Malvern TCE Site, Chester County, Pennsylvania.

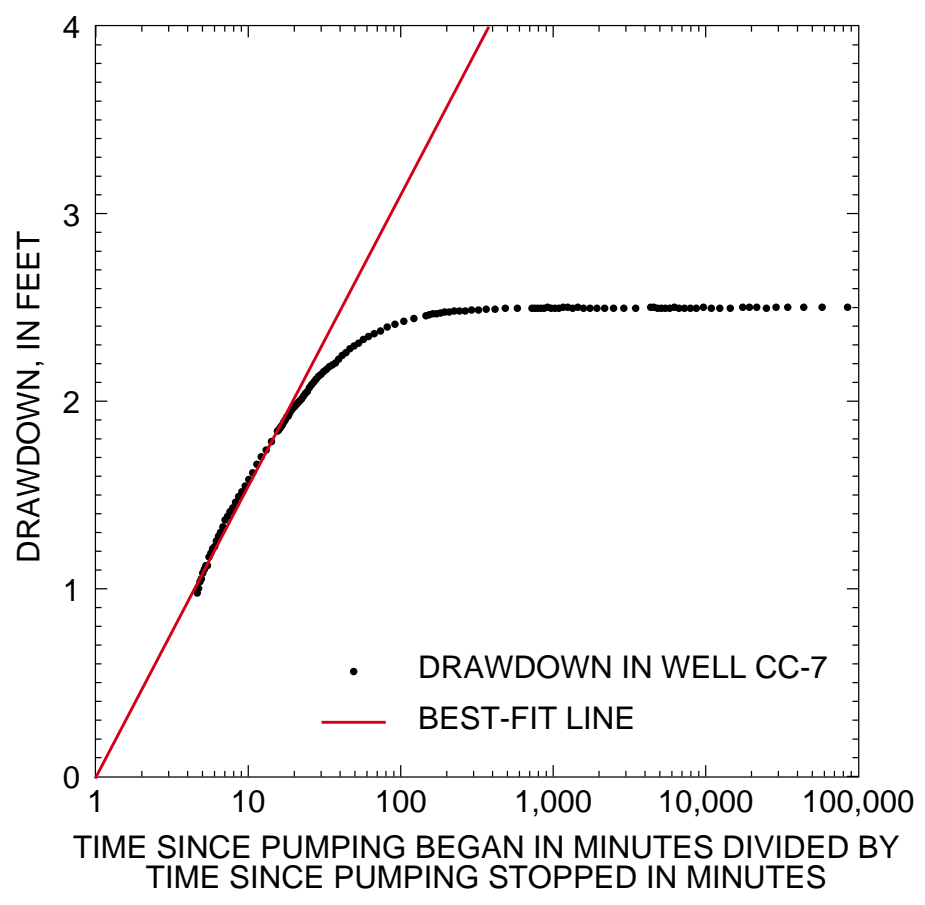

Figure 24. Relation between drawdown in well CC-7 and time for recovery phase of aquifer test of well CC-21, May 24, 1996, Malvern TCE Site, Chester County, Pennsylvania. 


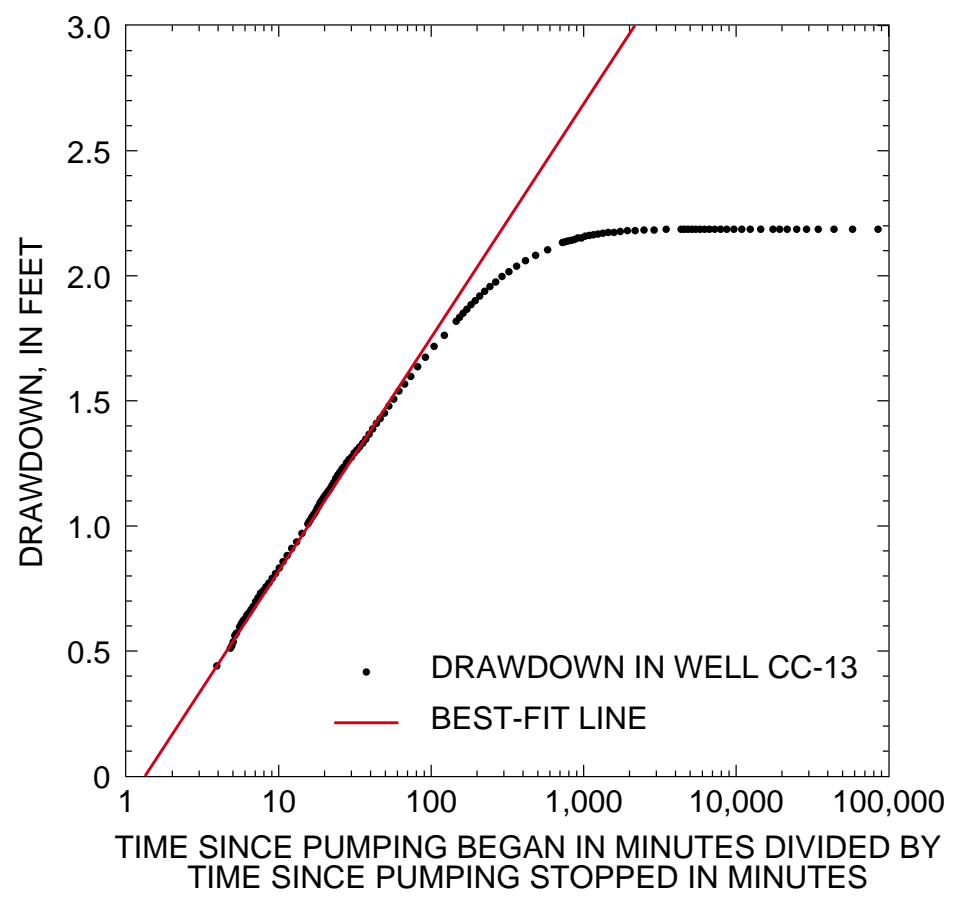

Figure 25. Relation between drawdown in well CC-13 and time for recovery phase of aquifer test of well CC-21, May 24, 1996, Malvern TCE Site, Chester County, Pennsylvania.

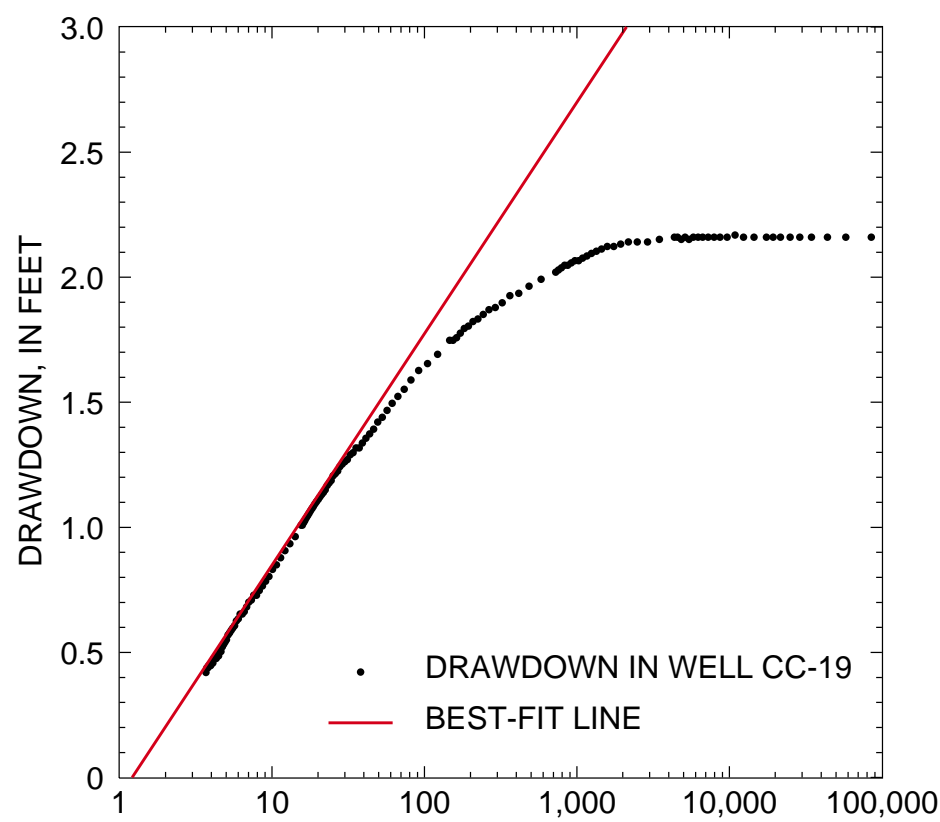

TIME SINCE PUMPING BEGAN IN MINUTES DIVIDED BY TIME SINCE PUMPING STOPPED IN MINUTES

Figure 26. Relation between drawdown in well CC-19 and time for recovery phase of aquifer test of well CC-21, May 24, 1996,

Malvern TCE Site, Chester County, Pennsylvania. 


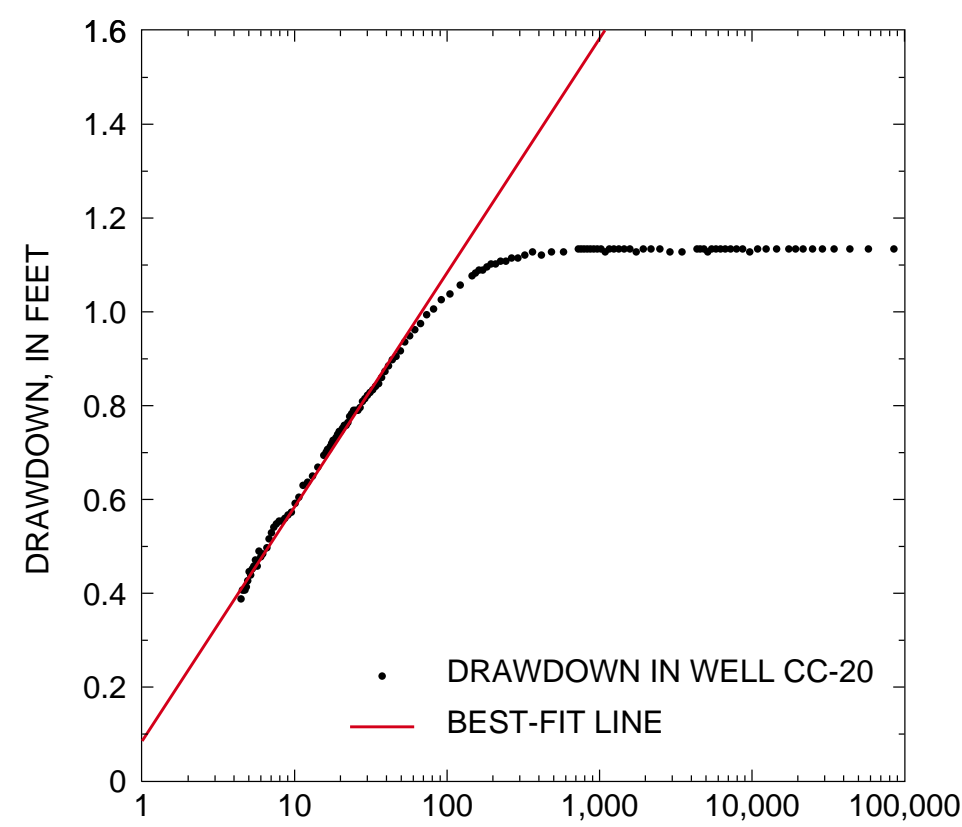

TIME SINCE PUMPING BEGAN IN MINUTES DIVIDED BY TIME SINCE PUMPING STOPPED IN MINUTES

Figure 27. Relation between drawdown in well CC-20 and time for recovery phase of aquifer test of well CC-21, May 24, 1996, Malvern TCE Site, Chester County, Pennsylvania.

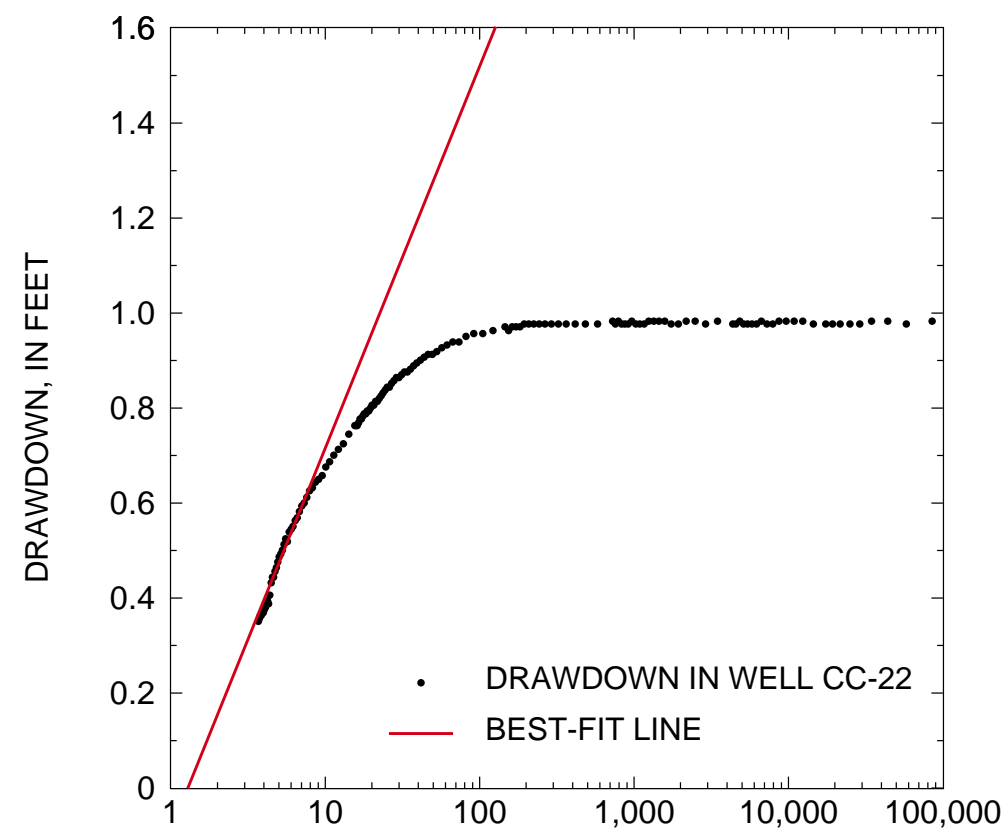

TIME SINCE PUMPING BEGAN IN MINUTES DIVIDED BY TIME SINCE PUMPING STOPPED IN MINUTES

Figure 28. Relation between drawdown in well CC-22 and time for recovery phase of aquifer test of well CC-21, May 24, 1996, Malvern TCE Site, Chester County, Pennsylvania. 


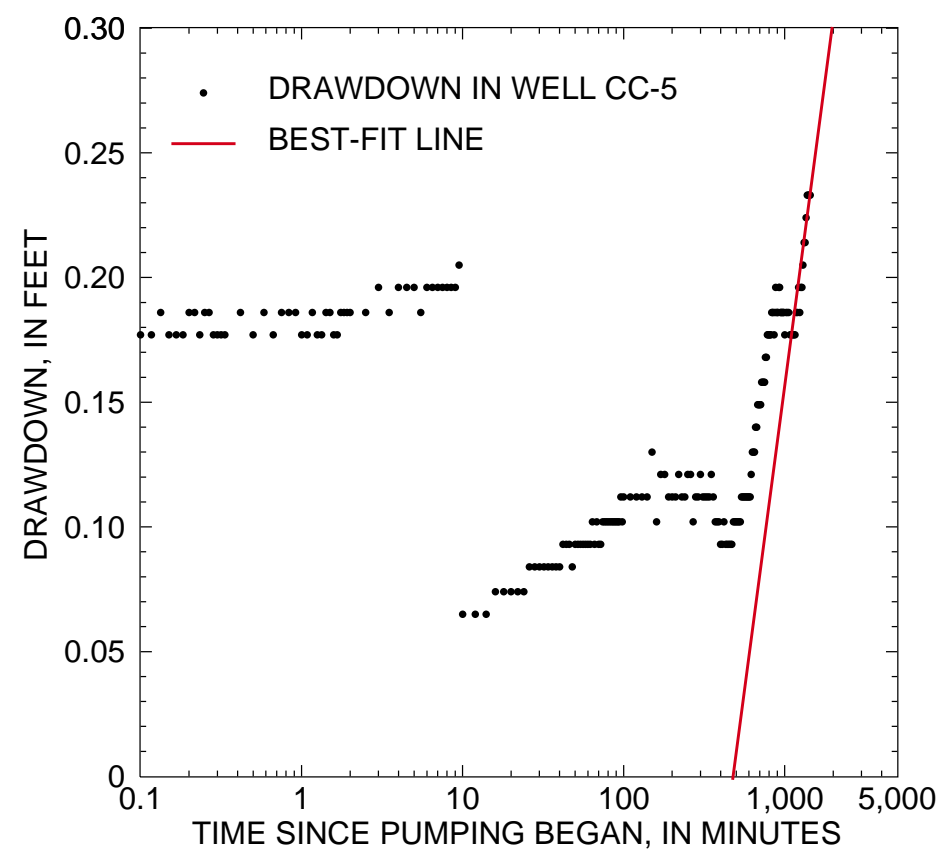

Figure 29. Relation between drawdown in well CC-5 and time for aquifer test of well CC-16, May 14-15, 1996, Malvern TCE Site, Chester County, Pennsylvania.

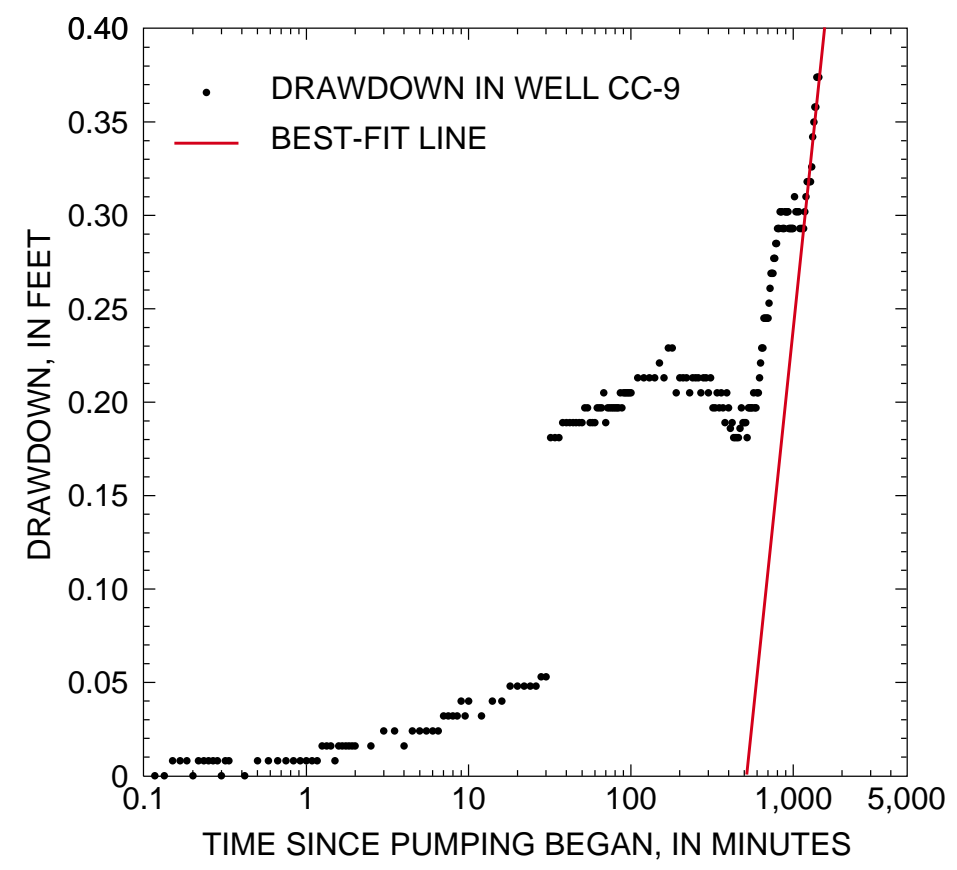

Figure 30. Relation between drawdown in well CC-9 and time for aquifer test of well CC-16, May 14-15, 1996, Malvern TCE Site, Chester County, Pennsylvania. 


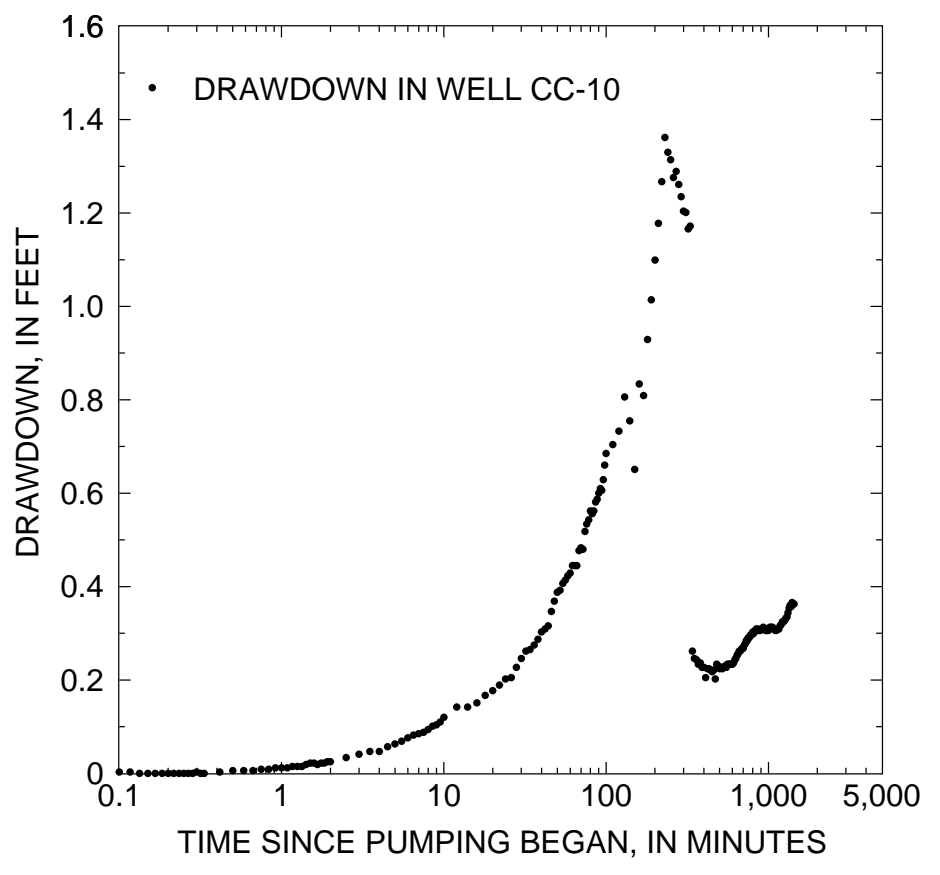

Figure 31. Relation between drawdown in well CC-10 and time for aquifer test of well CC-16, May 14-15, 1996, Malvern TCE Site, Chester County, Pennsylvania.

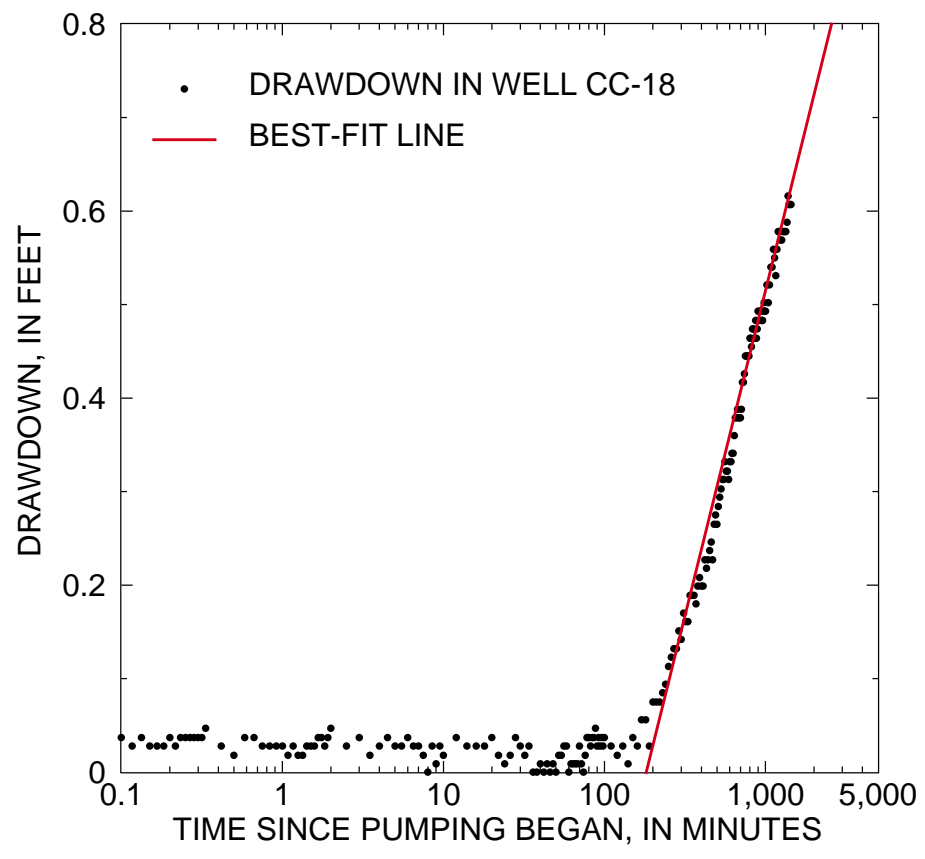

Figure 32. Relation between drawdown in well CC-18 and time for aquifer test of well CC-16, May 14-15, 1996, Malvern TCE Site, Chester County, Pennsylvania. 


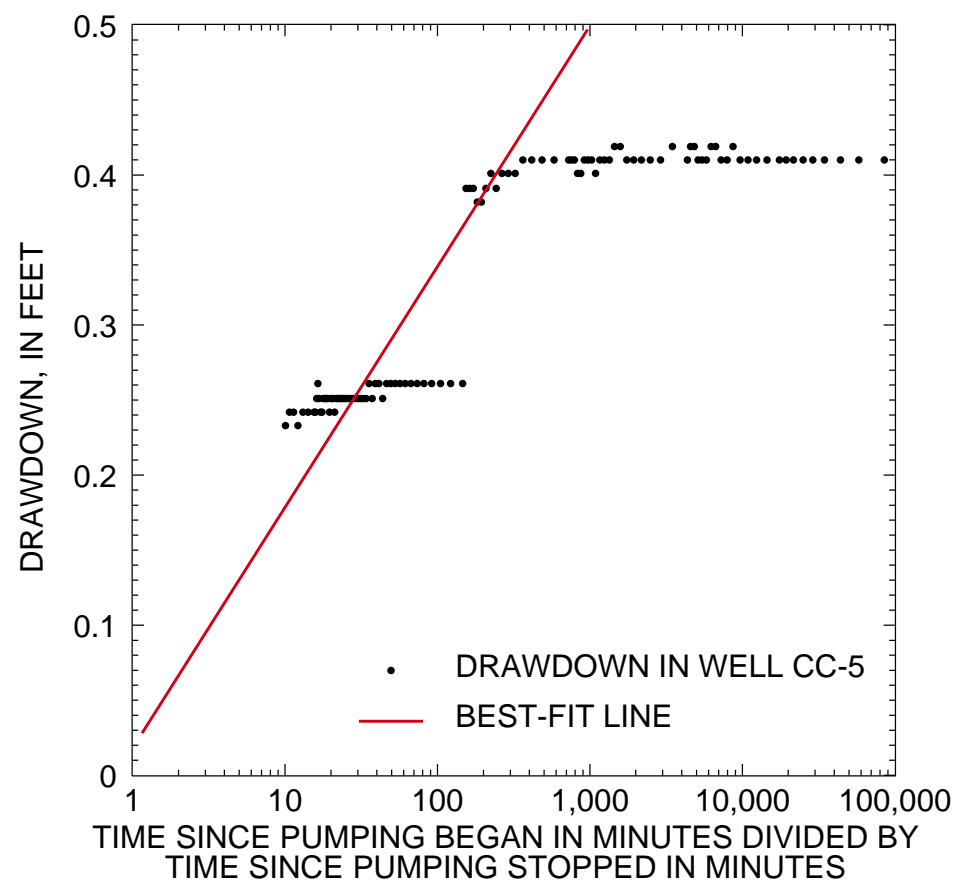

Figure 33. Relation between drawdown in well CC-5 and time for recovery phase of aquifer test of well CC-16, May 15, 1996, Malvern TCE Site, Chester County, Pennsylvania.

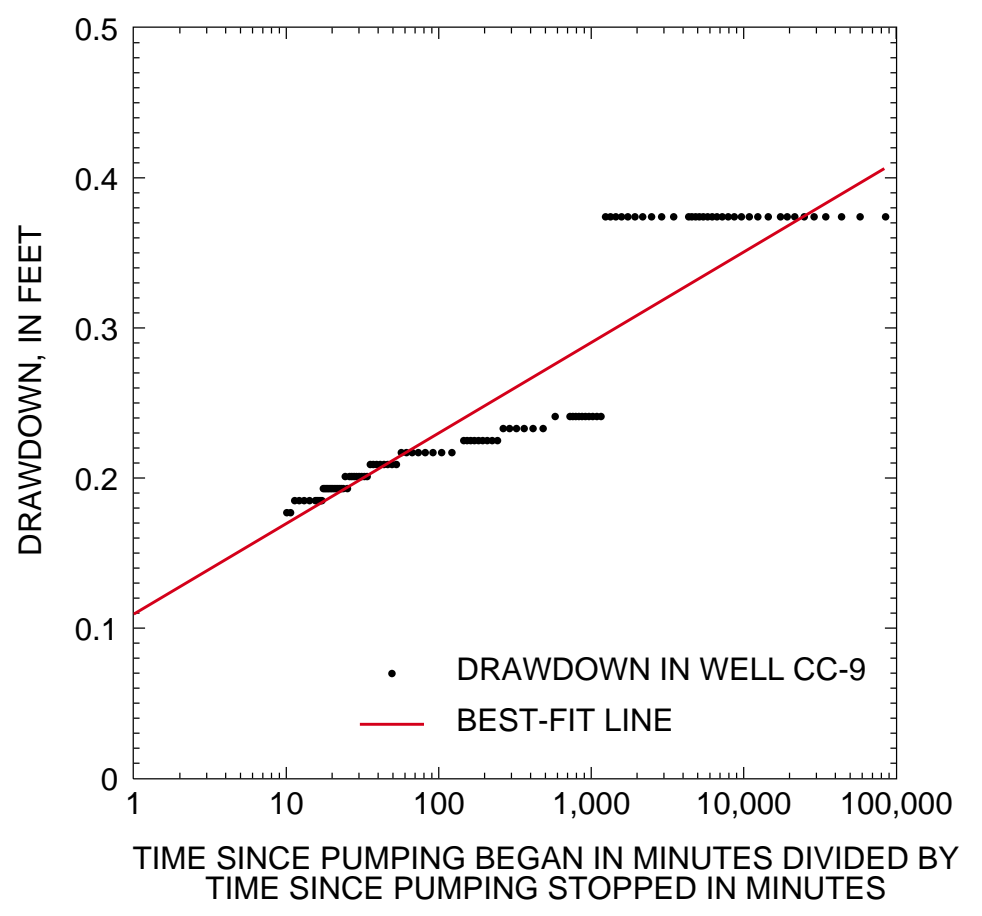

Figure 34. Relation between drawdown in well CC-9 and time for recovery phase of aquifer test of well CC-16, May 15, 1996, Malvern TCE Site, Chester County, Pennsylvania. 


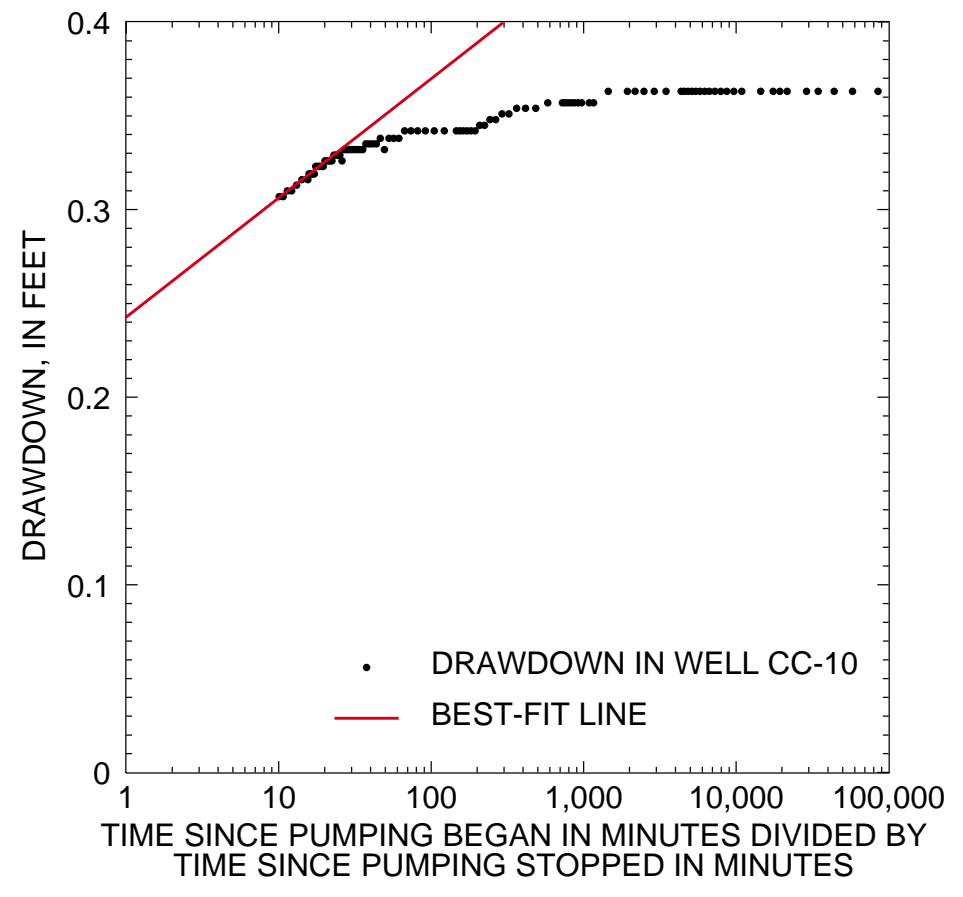

Figure 35. Relation between drawdown in well CC-10 and time for recovery phase of aquifer test of well CC-16, May 15, 1996, Malvern TCE Site, Chester County, Pennsylvania.

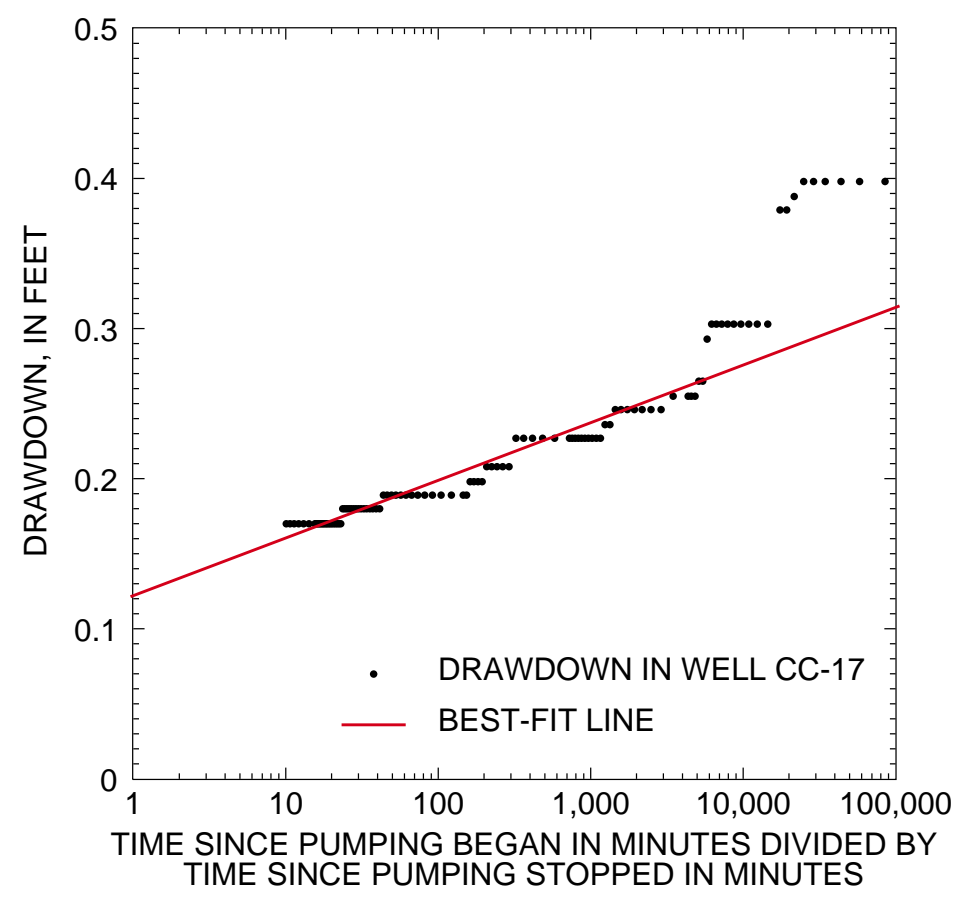

Figure 36. Relation between drawdown in well CC-17 and time for recovery phase of aquifer test of well CC-16, May 15, 1996, Malvern TCE Site, Chester County, Pennsylvania. 


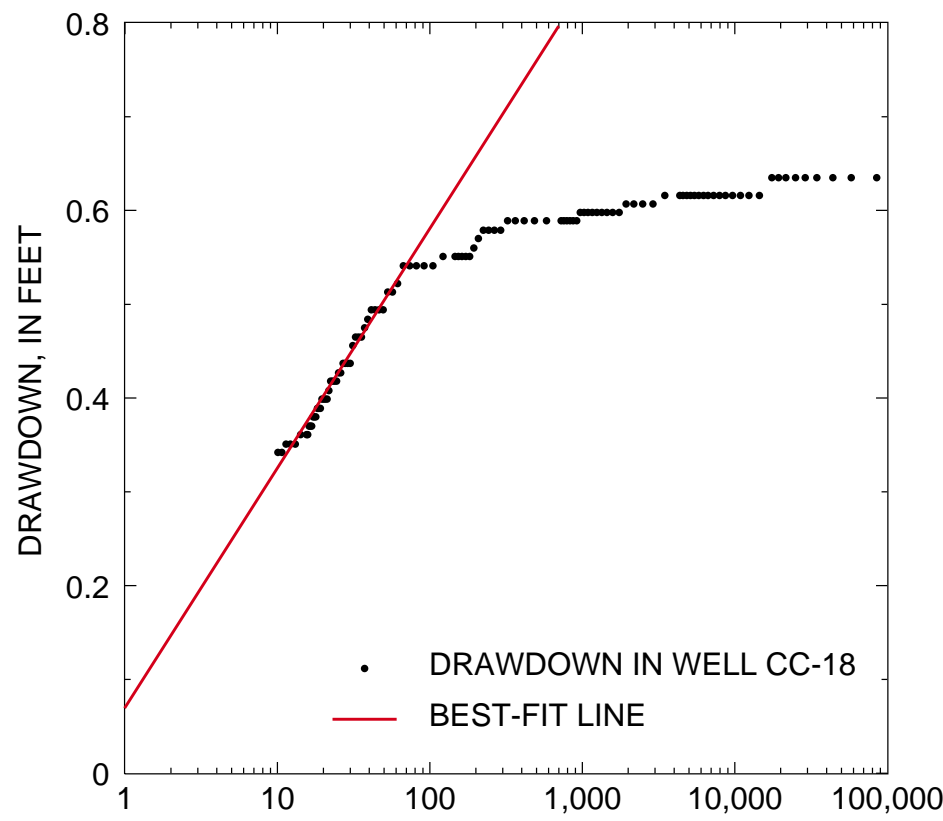

TIME SINCE PUMPING BEGAN IN MINUTES DIVIDED BY TIME SINCE PUMPING STOPPED IN MINUTES

Figure 37. Relation between drawdown in well CC-18 and time for recovery phase of aquifer test of well CC-16, May 15, 1996, Malvern TCE Site, Chester County, Pennsylvania.

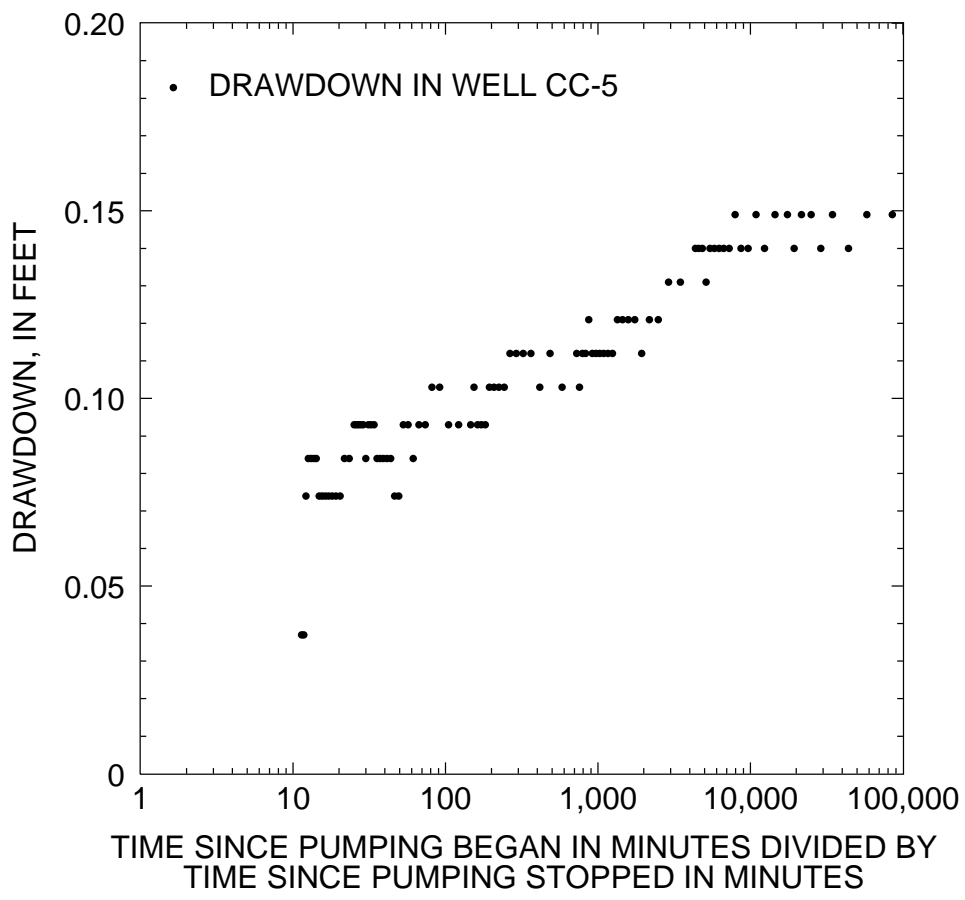

Figure 38. Relation between drawdown in well CC-5 and time for recovery phase of aquifer test of well CC-17, May 17, 1996, Malvern TCE Site, Chester County, Pennsylvania. 


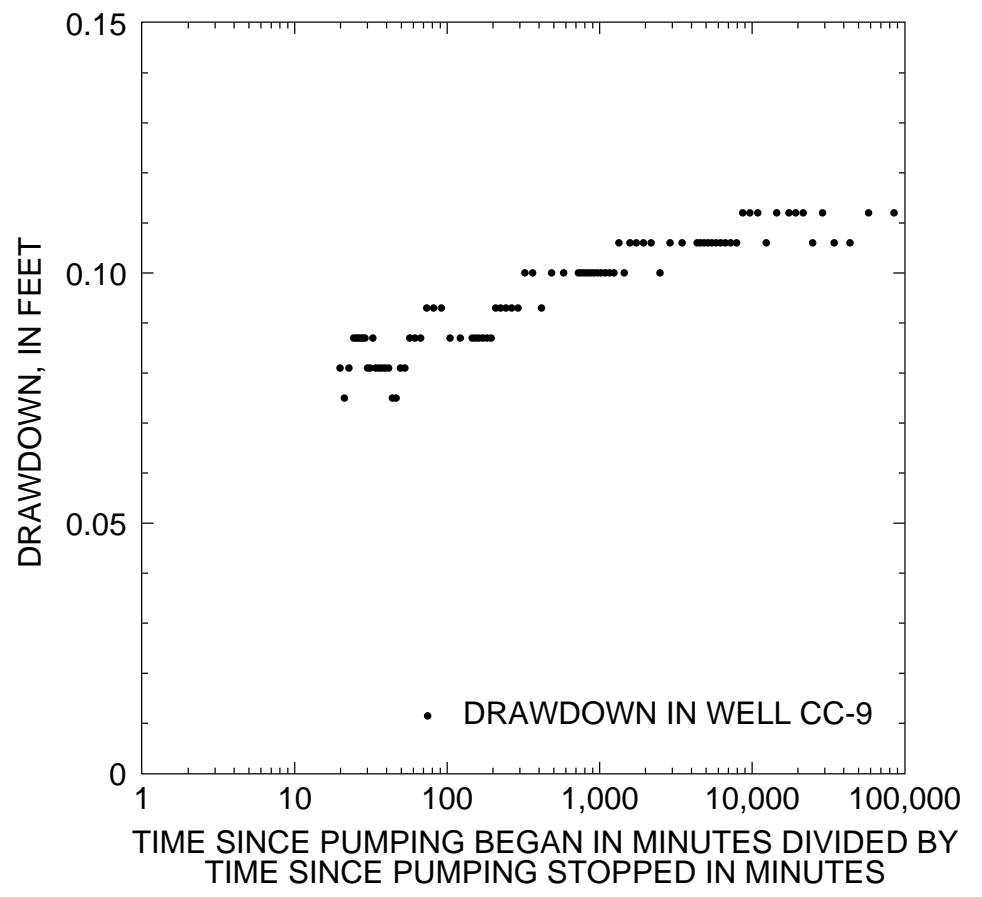

Figure 39. Relation between drawdown in well CC-9 and time for recovery phase of aquifer test of well CC-17, May 17, 1996, Malvern TCE Site, Chester County, Pennsylvania.

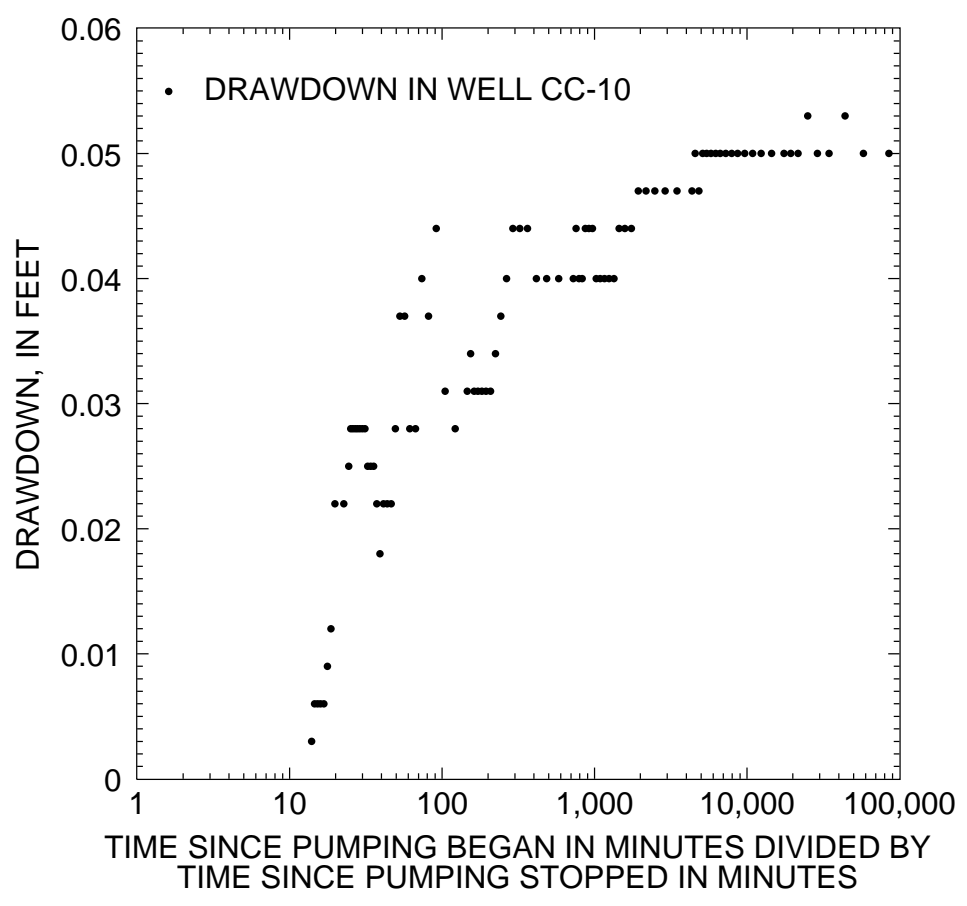

Figure 40. Relation between drawdown in well CC-10 and time for recovery phase of aquifer test of well CC-17, May 17, 1996, Malvern TCE Site, Chester County, Pennsylvania. 


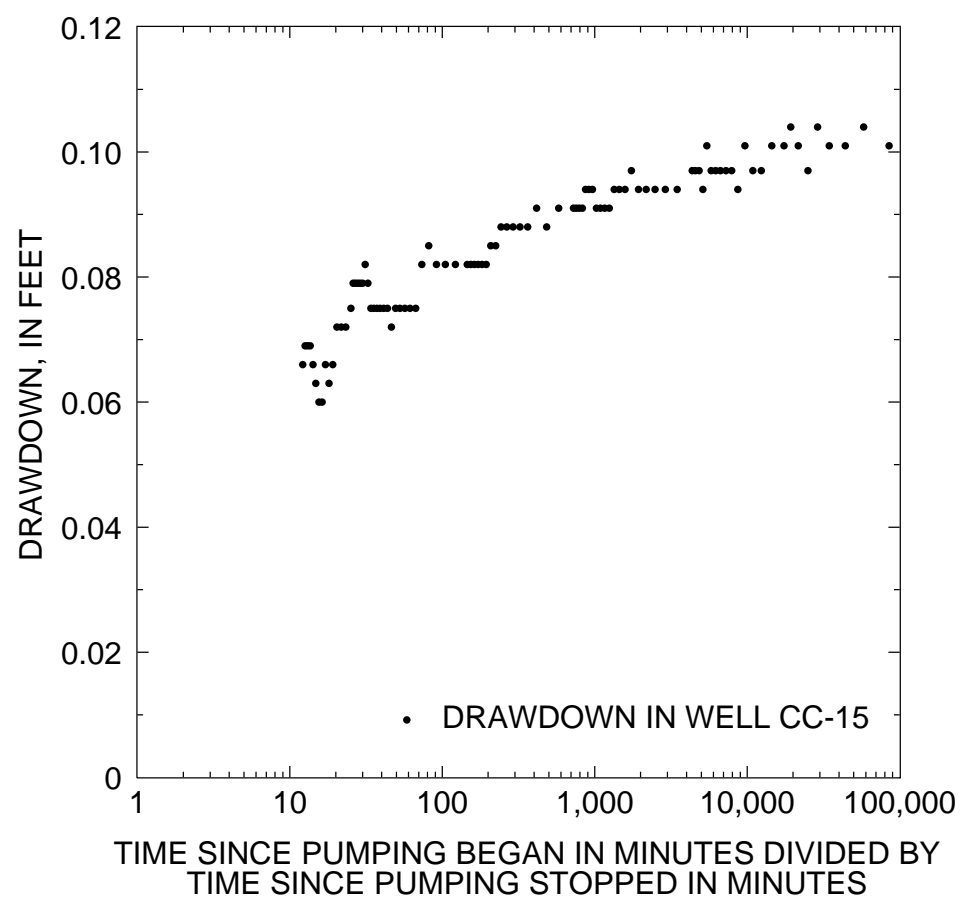

Figure 41. Relation between drawdown in well CC-15 and time for recovery phase of aquifer test of well CC-17, May 17, 1996, Malvern TCE Site, Chester County, Pennsylvania.

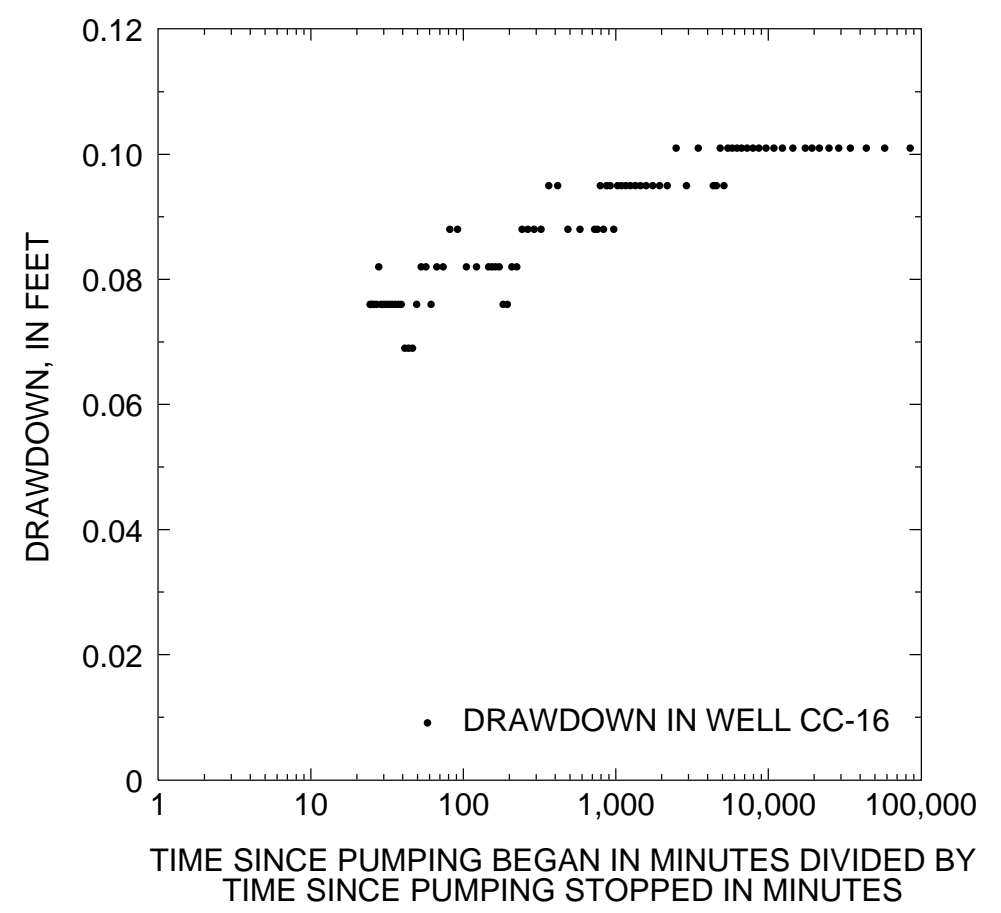

Figure 42. Relation between drawdown in well CC-16 and time for recovery phase of aquifer test of well CC-17, May 17, 1996, Malvern TCE Site, Chester County, Pennsylvania. 


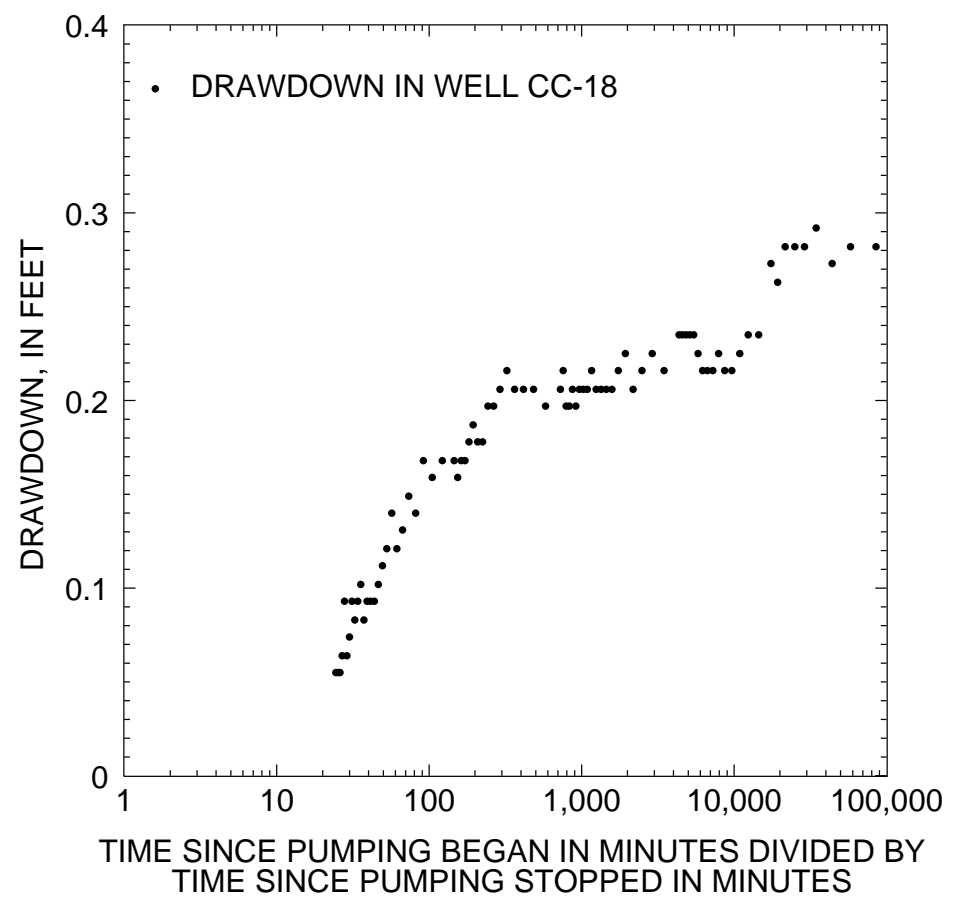

Figure 43. Relation between drawdown in well CC-18 and time for recovery phase of aquifer test of well CC-17, May 17, 1996,

Malvern TCE Site, Chester County, Pennsylvania. 


\section{APPENDIX 5. MONTHLY WATER-LEVEL MEASUREMENTS}


Table 1. Water levels (depth below land surface) measured monthly at the Malvern TCE Site, Chester County, Pennsylvania

$[--$, no data]

\begin{tabular}{|c|c|c|c|c|c|c|c|c|c|c|}
\hline \multirow{2}{*}{$\begin{array}{c}\text { Site well- } \\
\text { identification } \\
\text { number }\end{array}$} & \multirow{2}{*}{$\begin{array}{c}\text { U.S. } \\
\text { Geological } \\
\text { Survey well- } \\
\text { identification } \\
\text { number }\end{array}$} & \multicolumn{9}{|c|}{ Date of measurement } \\
\hline & & $1 / 4 / 95$ & 2/22/95 & 3/23/95 & 4/20/95 & $5 / 22 / 95$ & 6/19/95 & 7/20/95 & 8/22/95 & $9 / 20 / 95$ \\
\hline CC-2 & $\mathrm{CH}-5119$ & 74.10 & 74.71 & 71.27 & 72.49 & 73.73 & 75.54 & 78.03 & 80.40 & 82.39 \\
\hline CC-3 & $\mathrm{CH}-2627$ & 83.27 & 84.00 & 80.86 & 81.99 & 83.20 & 84.90 & 87.17 & 89.44 & 91.34 \\
\hline CC-5 & $\mathrm{CH}-5121$ & 59.18 & 59.01 & 54.99 & 56.29 & 57.82 & 60.28 & 63.01 & 65.52 & 67.46 \\
\hline CC-6 & $\mathrm{CH}-4405$ & 85.46 & 86.25 & 83.30 & 84.36 & 85.51 & 87.15 & 89.38 & 91.59 & 93.43 \\
\hline CC-7 & $\mathrm{CH}-4398$ & 84.63 & 85.63 & 82.61 & 83.68 & 84.86 & 86.52 & 88.75 & 90.95 & 92.86 \\
\hline CC-9 & $\mathrm{CH}-4396$ & 71.14 & 71.06 & 67.03 & 68.32 & 69.86 & 72.32 & 75.04 & 77.57 & 79.51 \\
\hline CC-10 & $\mathrm{CH}-5122$ & 54.22 & 54.07 & 50.04 & 51.35 & 52.90 & 55.34 & 58.09 & 60.58 & 62.53 \\
\hline $\mathrm{CC}-11$ & $\mathrm{CH}-5123$ & 62.64 & 62.77 & 59.61 & 60.54 & 61.87 & 63.90 & 66.35 & 68.63 & 70.46 \\
\hline CC-13- & $\mathrm{CH}-4404$ & 85.50 & 86.29 & 83.33 & 84.45 & 85.63 & 87.30 & 89.51 & 91.74 & 93.58 \\
\hline CC-14 & $\mathrm{CH}-5124$ & 86.01 & 85.72 & 81.77 & 82.79 & 84.34 & 86.77 & 89.57 & 92.15 & 94.04 \\
\hline \multirow{2}{*}{$\begin{array}{c}\text { Site well- } \\
\text { identification } \\
\text { number }\end{array}$} & & \multicolumn{8}{|c|}{ Date of measurement } & \\
\hline & $\begin{array}{c}\text { Survey well- } \\
\text { identification } \\
\text { number }\end{array}$ & $10 / 24 / 95$ & $11 / 30 / 95$ & $12 / 26 / 95$ & $1 / 18 / 96$ & 2/22/96 & $3 / 26 / 96$ & $4 / 24 / 96$ & $5 / 30 / 96$ & \\
\hline CC-2 & $\mathrm{CH}-5119$ & 82.13 & 80.51 & 81.80 & 81.96 & 71.14 & 66.51 & 59.42 & 60.17 & \\
\hline CC-3 & $\mathrm{CH}-2627$ & 91.18 & 89.77 & 90.92 & 91.16 & 80.81 & 77.23 & 69.15 & 69.96 & \\
\hline CC-5 & $\mathrm{CH}-5121$ & 66.42 & 64.65 & 65.82 & 66.05 & 52.71 & 47.65 & 43.19 & 44.86 & \\
\hline CC-6 & $\mathrm{CH}-4405$ & 93.28 & 91.96 & 93.04 & 93.23 & 83.14 & 78.76 & 72.25 & 72.69 & \\
\hline CC-7 & $\mathrm{CH}-4398$ & 93.17 & 91.29 & 92.44 & 92.44 & 82.45 & 77.94 & 71.12 & 71.82 & \\
\hline CC-9 & $\mathrm{CH}-4396$ & 78.46 & 76.68 & 77.85 & 78.03 & 64.72 & 60.49 & 55.21 & 56.77 & \\
\hline CC-10 & $\mathrm{CH}-5122$ & 61.47 & 59.72 & 60.91 & 61.05 & 49.47 & 43.53 & 38.25 & 39.93 & \\
\hline CC-11 & $\mathrm{CH}-5123$ & 70.06 & 68.83 & 69.89 & 70.11 & 59.39 & 54.92 & 49.65 & 45.57 & \\
\hline CC-13 & $\mathrm{CH}-4404$ & 93.37 & 92.08 & 93.21 & 93.36 & 82.94 & 78.66 & 71.92 & 72.59 & \\
\hline CC-14 & $\mathrm{CH}-5124$ & 93.13 & 91.31 & 92.46 & 92.67 & 75.51 & 75.14 & 69.78 & 71.22 & \\
\hline CC-15 & $\mathrm{CH}-5142$ & -- & 66.90 & 68.05 & 68.23 & 54.91 & 50.81 & 45.55 & 47.20 & \\
\hline CC-16 & $\mathrm{CH}-5143$ & -- & -- & 67.18 & 68.48 & 54.83 & 50.59 & 45.31 & 46.93 & \\
\hline CC-17 & $\mathrm{CH}-5144$ & -- & -- & -- & -- & 55.54 & 51.33 & 46.05 & 47.70 & \\
\hline CC-18 & $\mathrm{CH}-5145$ & -- & -- & -- & -- & 55.70 & 51.48 & 46.30 & 47.92 & \\
\hline CC-19 & $\mathrm{CH}-5146$ & -- & -- & -- & -- & -- & -- & 70.01 & 71.31 & \\
\hline CC-20 & $\mathrm{CH}-5147$ & -- & -- & -- & -- & -- & 76.47 & 69.71 & 70.69 & \\
\hline CC-21 & $\mathrm{CH}-5148$ & -- & -- & -- & -- & -- & 79.45 & 73.27 & 73.54 & \\
\hline CC-22 & $\mathrm{CH}-5149$ & -- & -- & -- & -- & -- & 83.55 & 76.08 & 70.07 & \\
\hline
\end{tabular}


Table 2. Water levels (altitude above sea level) measured monthly at the Malvern TCE Site, Chester County, Pennsylvania

[--, no data]

\begin{tabular}{|c|c|c|c|c|c|c|c|c|c|c|}
\hline \multirow{2}{*}{$\begin{array}{c}\text { Site well- } \\
\text { identification } \\
\text { number }\end{array}$} & \multirow{2}{*}{$\begin{array}{c}\text { U.S. } \\
\text { Geological } \\
\text { Survey well- } \\
\text { identification } \\
\text { number }\end{array}$} & \multicolumn{9}{|c|}{ Date of measurement } \\
\hline & & $1 / 4 / 95$ & 2/22/95 & 3/23/95 & $4 / 20 / 95$ & $5 / 22 / 95$ & 6/19/95 & $7 / 20 / 95$ & 8/22/95 & 9/20/95 \\
\hline $\mathrm{CC}-2$ & $\mathrm{CH}-5119$ & 295.32 & 294.71 & 298.15 & 296.93 & 295.69 & 293.88 & 291.39 & 289.02 & 287.03 \\
\hline CC-3 & $\mathrm{CH}-2627$ & 292.93 & 292.20 & 295.34 & 294.21 & 293.00 & 291.30 & 289.03 & 286.76 & 284.86 \\
\hline CC-5 & $\mathrm{CH}-5121$ & 304.73 & 304.90 & 308.92 & 307.62 & 306.09 & 303.63 & 300.90 & 298.39 & 296.45 \\
\hline CC-6 & $\mathrm{CH}-4405$ & 291.07 & 290.28 & 293.23 & 292.17 & 291.02 & 289.38 & 287.15 & 284.94 & 283.10 \\
\hline CC-7 & $\mathrm{CH}-4398$ & 292.78 & 291.78 & 294.80 & 293.73 & 292.55 & 290.89 & 288.66 & 286.46 & 284.55 \\
\hline CC-9 & $\mathrm{CH}-4396$ & 304.57 & 304.65 & 308.68 & 307.39 & 305.85 & 303.39 & 300.67 & 298.14 & 296.20 \\
\hline CC-10 & $\mathrm{CH}-5122$ & 304.65 & 304.80 & 308.83 & 307.52 & 305.97 & 303.53 & 300.78 & 298.29 & 296.34 \\
\hline CC-11 & $\mathrm{CH}-5123$ & 306.45 & 306.32 & 309.48 & 308.55 & 307.22 & 305.19 & 302.74 & 300.46 & 298.63 \\
\hline CC-13 & $\mathrm{CH}-4404$ & 292.44 & 291.65 & 294.61 & 293.49 & 292.31 & 290.64 & 288.43 & 286.20 & 284.36 \\
\hline CC-14 & $\mathrm{CH}-5124$ & 304.49 & 304.78 & 308.73 & 307.71 & 306.16 & 303.73 & 300.93 & 298.35 & 296.46 \\
\hline \multirow{2}{*}{$\begin{array}{c}\text { Site well- } \\
\text { identification } \\
\text { number }\end{array}$} & & \multicolumn{8}{|c|}{ Date of measurement } & \\
\hline & $\begin{array}{c}\text { Survey well- } \\
\text { identification } \\
\text { number }\end{array}$ & $10 / 24 / 95$ & $11 / 30 / 95$ & $12 / 26 / 95$ & $1 / 18 / 96$ & 2/22/96 & $3 / 26 / 96$ & $4 / 24 / 96$ & $5 / 30 / 96$ & \\
\hline CC-2 & $\mathrm{CH}-5119$ & 287.29 & 288.91 & 287.62 & 287.46 & 298.28 & 302.91 & 310.00 & 309.25 & \\
\hline CC-3 & $\mathrm{CH}-2627$ & 285.02 & 286.43 & 285.28 & 285.04 & 295.39 & 298.97 & 307.05 & 306.24 & \\
\hline CC-5 & $\mathrm{CH}-5121$ & 297.49 & 299.26 & 298.09 & 297.86 & 311.20 & 315.31 & 320.72 & 319.05 & \\
\hline CC-6 & $\mathrm{CH}-4405$ & 283.25 & 284.57 & 283.49 & 283.30 & 293.39 & 297.77 & 304.28 & 303.84 & \\
\hline CC-7 & CH-4398 & 284.24 & 286.12 & 284.97 & 284.97 & 294.96 & 299.47 & 306.29 & 305.59 & \\
\hline CC-9 & $\mathrm{CH}-4396$ & 297.25 & 299.03 & 297.86 & 297.68 & 310.99 & 315.22 & 320.05 & 318.94 & \\
\hline CC-10 & $\mathrm{CH}-5122$ & 297.40 & 299.15 & 297.96 & 297.82 & 310.98 & 315.34 & 320.62 & 318.94 & \\
\hline CC-11 & $\mathrm{CH}-5123$ & 299.03 & 300.26 & 299.20 & 298.98 & 309.70 & 314.17 & 319.44 & 319.52 & \\
\hline CC-13 & $\mathrm{CH}-4404$ & 284.57 & 285.86 & 284.73 & 284.58 & 295.00 & 299.28 & 306.02 & 305.35 & \\
\hline CC-14 & $\mathrm{CH}-5124$ & 297.37 & 299.19 & 298.04 & 297.83 & 310.99 & 315.36 & 320.72 & 319.28 & \\
\hline
\end{tabular}




\section{APPENDIX 6. RESULTS OF CHEMICAL ANALYSES FOR VOLATILE ORGANIC COMPOUNDS}


Table 1. Results of chemical analyses for volatile organic compounds in water samples from on-site wells sampled by the U.S. Geological Survey, Malvern TCE Site, Chester County, Pennsylvania

[Concentrations in micrograms per liter; 1 , sampled near end of well development; 2 , sampled near end of aquifer test; 3 , sampled near end of aquifer-isolation test; <, less than; $\mathrm{J}$, estimated value for compound detected below the specified detection limit]

\begin{tabular}{|c|c|c|c|c|c|c|c|c|c|c|c|}
\hline $\begin{array}{l}\text { Site well- } \\
\text { identification } \\
\text { number }\end{array}$ & Notes & $\begin{array}{c}\text { U.S. } \\
\text { Geological } \\
\text { Survey well- } \\
\text { identification } \\
\text { number }\end{array}$ & Date & Acetone & Benzene & $\begin{array}{l}\text { Bromo- } \\
\text { dichloro- } \\
\text { methane }\end{array}$ & Bromoform & $\begin{array}{l}\text { Bromo- } \\
\text { methane }\end{array}$ & 2-Butanone & $\begin{array}{l}\text { Carbon } \\
\text { disulfide }\end{array}$ & $\begin{array}{c}\text { Carbon } \\
\text { tetrachloride }\end{array}$ \\
\hline$\overline{C C-15}$ & 1 & $\mathrm{CH} 5142$ & $4 / 15 / 96$ & $<20$ & $<5$ & $<5$ & $<5$ & $<10$ & $<20$ & $<5$ & $<5$ \\
\hline CC-16 & 1 & CH 5143 & 4/17/96 & $<20$ & $<5$ & $<5$ & $<5$ & $<10$ & $<20$ & $<5$ & $<5$ \\
\hline CC-16 & 2 & & $5 / 22 / 96$ & $<20$ & $<5$ & $<5$ & $<5$ & $<10$ & $<20$ & $<5$ & $<5$ \\
\hline CC-17 & 1 & CH 5144 & $4 / 17 / 96$ & $<20$ & $<5$ & $<5$ & $<5$ & $<10$ & $<20$ & $<5$ & $<5$ \\
\hline CC-17 & 2 & & $5 / 17 / 96$ & $<20$ & $<5$ & $<5$ & $<5$ & $<10$ & $<20$ & $<5$ & $<5$ \\
\hline CC-18 & 1 & CH 5145 & 4/17/96 & $<20$ & $<5$ & $<5$ & $<5$ & $<10$ & $<20$ & $<5$ & $<5$ \\
\hline CC-19 & 3 & CH 5146 & & & & & & & & & \\
\hline \multicolumn{2}{|c|}{ Upper zone } & & $5 / 02 / 96$ & $<20$ & $<5$ & $<5$ & $<5$ & $<10$ & $<20$ & $<5$ & $<5$ \\
\hline \multicolumn{2}{|c|}{ Lower zone } & & $5 / 02 / 96$ & $<20$ & $<5$ & $<5$ & $<5$ & $<10$ & $<20$ & $<5$ & $<5$ \\
\hline CC-19 & 2 & & $5 / 22 / 96$ & $<20$ & $<5$ & $<5$ & $<5$ & $<10$ & $<20$ & $<5$ & $<5$ \\
\hline CC-20 & 1 & CH 5147 & $4 / 22 / 96$ & $<20$ & $<5$ & $<5$ & $<5$ & $<10$ & $<20$ & $<5$ & $<5$ \\
\hline CC-21 & 1 & CH 5148 & 4/22/96 & $<20$ & $<5$ & $<5$ & $<5$ & $<10$ & $<20$ & $<5$ & $<5$ \\
\hline CC-21 & 2 & & $5 / 24 / 96$ & $<20$ & $<5$ & $<5$ & $<5$ & $<10$ & $<20$ & $<5$ & $<5$ \\
\hline CC-22 & 1 & CH 5149 & $4 / 24 / 96$ & $<20$ & $<5$ & $<5$ & $<5$ & $<10$ & $<20$ & $<5$ & $<5$ \\
\hline $\begin{array}{l}\text { Site well- } \\
\text { identification } \\
\text { number }\end{array}$ & Notes & $\begin{array}{c}\text { U.S. } \\
\text { Geological } \\
\text { Survey well- } \\
\text { identification } \\
\text { number }\end{array}$ & Date & $\begin{array}{l}\text { Chloro- } \\
\text { benzene }\end{array}$ & $\begin{array}{l}\text { Chloro- } \\
\text { ethane }\end{array}$ & $\begin{array}{l}\text { 2-Chloro- } \\
\text { ethylvinyl- } \\
\text { ether }\end{array}$ & Chloroform & $\begin{array}{l}\text { Chloro- } \\
\text { methane }\end{array}$ & $\begin{array}{l}\text { Dibromo- } \\
\text { chloro- } \\
\text { methane }\end{array}$ & $\begin{array}{l}\text { 1,1-Dichloro- } \\
\text { ethane }\end{array}$ & $\begin{array}{l}1,2-\mathrm{Di}- \\
\text { chloro- } \\
\text { ethane }\end{array}$ \\
\hline CC-15 & 1 & $\mathrm{CH} 5142$ & $4 / 15 / 96$ & $<5$ & $<10$ & $<20$ & $<5$ & $<10$ & $<5$ & $<5$ & 9.3 \\
\hline CC-16 & 1 & CH 5143 & $4 / 17 / 96$ & $<5$ & $<10$ & $<20$ & $2.7 \mathrm{~J}$ & $<10$ & $<5$ & $<5$ & $<5$ \\
\hline CC-16 & 2 & & $5 / 22 / 96$ & $<5$ & $<10$ & $<20$ & $3.6 \mathrm{~J}$ & $<10$ & $<5$ & $3.1 \mathrm{~J}$ & 7.2 \\
\hline CC-17 & 1 & CH 5144 & $4 / 17 / 96$ & $<5$ & $<10$ & $<20$ & $<5$ & $<10$ & $<5$ & $<5$ & $<5$ \\
\hline CC-17 & 2 & & $5 / 17 / 96$ & $<5$ & $<10$ & $<20$ & $<5$ & $<10$ & $<5$ & $3.2 \mathrm{~J}$ & $3.2 \mathrm{~J}$ \\
\hline CC-18 & 1 & $\mathrm{CH} 5145$ & $4 / 17 / 96$ & $<5$ & $<10$ & $<20$ & $<5$ & $<10$ & $<5$ & $<5$ & $<5$ \\
\hline CC-19 & 3 & CH 5146 & & & & & & & & & \\
\hline \multicolumn{2}{|c|}{ Upper zone } & & $5 / 02 / 96$ & $<5$ & $<10$ & $<20$ & $<5$ & $<10$ & $<5$ & $<5$ & $<5$ \\
\hline \multicolumn{2}{|c|}{ Lower zone } & & $5 / 02 / 96$ & $<5$ & $<10$ & $<20$ & $<5$ & $<10$ & $<5$ & $<5$ & $<5$ \\
\hline CC-19 & 2 & & $5 / 22 / 96$ & $<5$ & $<10$ & $<20$ & 27.8 & $<10$ & $<5$ & 6.8 & 28.9 \\
\hline CC-20 & 1 & CH 5147 & 4/22/96 & $<5$ & $<10$ & $<20$ & $<5$ & $<10$ & $<5$ & $<5$ & $<5$ \\
\hline CC-21 & 1 & CH 5148 & 4/22/96 & $<5$ & $<10$ & $<20$ & 66.5 & $<10$ & $<5$ & 29.1 & 90.6 \\
\hline CC-21 & 2 & & $5 / 24 / 96$ & $<5$ & $<10$ & $<20$ & 171 & $<10$ & $<5$ & 37.5 & 148 \\
\hline CC-22 & 1 & CH 5149 & 4/24/96 & $<5$ & $<10$ & $<20$ & $<5$ & $<10$ & $<5$ & $<5$ & $<5$ \\
\hline $\begin{array}{l}\text { Site well- } \\
\text { identification } \\
\text { number }\end{array}$ & Notes & $\begin{array}{c}\text { U.S. } \\
\text { Geological } \\
\text { Survey well- } \\
\text { identification } \\
\text { number }\end{array}$ & Date & $\begin{array}{l}\text { 1,1-Dichloro- } \\
\text { ethene }\end{array}$ & $\begin{array}{l}\text { cis-1,2- } \\
\text { Dichloro- } \\
\text { ethylene }\end{array}$ & $\begin{array}{l}\text { trans-1,2- } \\
\text { Dichloro- } \\
\text { ethylene }\end{array}$ & $\begin{array}{l}\text { 1,2-Dichloro- } \\
\text { propane }\end{array}$ & $\begin{array}{l}\text { cis-1,3- } \\
\text { Dichloro- } \\
\text { propene }\end{array}$ & $\begin{array}{l}\text { trans-1,3- } \\
\text { Dichloro- } \\
\text { propene }\end{array}$ & $\begin{array}{l}\text { Ethyl- } \\
\text { benzene }\end{array}$ & 2-Hexanone \\
\hline CC-15 & 1 & $\mathrm{CH} 5142$ & $4 / 15 / 96$ & 15.4 & 26.6 & $<5$ & $<5$ & $<5$ & $<5$ & $<5$ & $<20$ \\
\hline CC-16 & 1 & $\mathrm{CH} 5143$ & $4 / 17 / 96$ & 35.1 & 198 & $<5$ & $<5$ & $<5$ & $<5$ & $<5$ & $<20$ \\
\hline CC-16 & 2 & & $5 / 22 / 96$ & 15.6 & 356 & $<5$ & $<5$ & $<5$ & $<5$ & $<5$ & $<20$ \\
\hline CC-17 & 1 & CH 5144 & $4 / 17 / 96$ & $4.7 \mathrm{~J}$ & 63.3 & $<5$ & $<5$ & $<5$ & $<5$ & $<5$ & $<20$ \\
\hline CC-17 & 2 & & $5 / 17 / 96$ & $4.7 \mathrm{~J}$ & 260 & $<5$ & $<5$ & $<5$ & $<5$ & $<5$ & $<20$ \\
\hline CC-18 & 1 & CH 5145 & $4 / 17 / 96$ & $<5$ & 10.6 & $<5$ & $<5$ & $<5$ & $<5$ & $<5$ & $<20$ \\
\hline CC-19 & 3 & $\mathrm{CH} 5146$ & & & & & & & & & \\
\hline \multicolumn{2}{|c|}{ Upper zone } & & $5 / 02 / 96$ & 22.8 & 11.9 & $<5$ & $<5$ & $<5$ & $<5$ & $<5$ & $<20$ \\
\hline \multicolumn{2}{|c|}{ Lower zone } & & $5 / 02 / 96$ & 13.7 & $2.7 \mathrm{~J}$ & $<5$ & $<5$ & $<5$ & $<5$ & $<5$ & $<20$ \\
\hline CC-19 & 2 & & $5 / 22 / 96$ & 91.7 & 126 & $<5$ & $<5$ & $<5$ & $<5$ & $<5$ & $<20$ \\
\hline CC-20 & 1 & CH 5147 & $4 / 22 / 96$ & $<5$ & $<5$ & $<5$ & $<5$ & $<5$ & $<5$ & $<5$ & $<20$ \\
\hline CC-21 & 1 & CH 5148 & $4 / 22 / 96$ & 359 & 496 & $3.1 \mathrm{~J}$ & $<5$ & $<5$ & $<5$ & $<5$ & $<20$ \\
\hline CC-21 & 2 & & $5 / 24 / 96$ & 522 & 811 & $2.7 \mathrm{~J}$ & $<5$ & $<5$ & $<5$ & $<5$ & $<20$ \\
\hline CC-22 & 1 & $\mathrm{CH} 5149$ & 4/24/96 & $5.0 \mathrm{~J}$ & $2.3 \mathrm{~J}$ & $<5$ & $<5$ & $<5$ & $<5$ & $<5$ & $<20$ \\
\hline
\end{tabular}


Table 1. Results of chemical analyses for volatile organic compounds in water samples from on-site wells sampled by the U.S. Geological Survey, Malvern TCE Site, Chester County, Pennsylvania-Continued

[Concentrations in micrograms per liter; 1 , sampled near end of well development; 2, sampled near end of aquifer test; 3 , sampled near end of aquifer-isolation test; <, less than; J, estimated value for compound detected below the specified detection limit]

\begin{tabular}{|c|c|c|c|c|c|c|c|c|c|c|c|}
\hline $\begin{array}{l}\text { Site well- } \\
\text { identification } \\
\text { number }\end{array}$ & Notes & $\begin{array}{c}\text { U.S. } \\
\text { Geological } \\
\text { Survey well- } \\
\text { identification } \\
\text { number }\end{array}$ & Date & $\begin{array}{l}\text { Methylene } \\
\text { chloride }\end{array}$ & $\begin{array}{l}\text { 4-Methyl-2- } \\
\text { pentanone }\end{array}$ & Styrene & $\begin{array}{c}1,1,2,2- \\
\text { Tetrachloro- } \\
\text { ethane }\end{array}$ & $\begin{array}{c}\text { Tetrachloro- } \\
\text { ethylene }\end{array}$ & $\begin{array}{c}1,1,1- \\
\text { Trichloro- } \\
\text { ethane }\end{array}$ & $\begin{array}{c}1,1,2- \\
\text { Trichloro- } \\
\text { ethane }\end{array}$ & $\begin{array}{l}\text { Trichloro- } \\
\text { ethylene }\end{array}$ \\
\hline CC-15 & 1 & $\mathrm{CH} 5142$ & $4 / 15 / 96$ & $<5$ & $<20$ & $<5$ & $<5$ & 69.8 & 33.3 & $<5$ & 106 \\
\hline CC-16 & 1 & CH 5143 & $4 / 17 / 96$ & $<5$ & $<20$ & $<5$ & $<5$ & 101 & 84.8 & 7.3 & 180 \\
\hline CC-16 & 2 & & $5 / 22 / 96$ & $<5$ & $<20$ & $<5$ & $<5$ & 68.7 & 78.9 & 7.3 & 152 \\
\hline CC-17 & 1 & CH 5144 & $4 / 17 / 96$ & $<5$ & $<20$ & $<5$ & $<5$ & 22.0 & 14.8 & $<5$ & 44.4 \\
\hline CC-17 & 2 & & $5 / 17 / 96$ & $<5$ & $<20$ & $<5$ & $<5$ & 26.5 & 28.3 & $2.6 \mathrm{~J}$ & 89.2 \\
\hline CC-18 & 1 & CH 5145 & $4 / 17 / 96$ & $<5$ & $<20$ & $<5$ & $<5$ & $2.3 \mathrm{~J}$ & $3.6 \mathrm{~J}$ & $<5$ & 7.3 \\
\hline CC-19 & 3 & CH 5146 & & & & & & & & & \\
\hline \multicolumn{2}{|c|}{ Upper zone } & & $5 / 02 / 96$ & $<5$ & $<20$ & $<5$ & $<5$ & 60.5 & 39.5 & $<5$ & 144 \\
\hline \multicolumn{2}{|c|}{ Lower zone } & & $5 / 02 / 96$ & $<5$ & $<20$ & $<5$ & $<5$ & 41.2 & 24.1 & $<5$ & 82.2 \\
\hline CC-19 & 2 & & $5 / 22 / 96$ & $2.6 \mathrm{~J}$ & $<20$ & $<5$ & $<5$ & 185 & 416 & $<5$ & 1,640 \\
\hline CC-20 & 1 & $\mathrm{CH} 5147$ & 4/22/96 & $<5$ & $<20$ & $<5$ & $<5$ & $3.2 \mathrm{~J}$ & $2.2 \mathrm{~J}$ & $<5$ & 7.6 \\
\hline CC-21 & 1 & CH 5148 & 4/22/96 & $<5$ & $<20$ & $<5$ & $<5$ & 744 & 1,060 & 7.3 & 4,330 \\
\hline CC-21 & 2 & & $5 / 24 / 96$ & $3.0 \mathrm{~J}$ & $<20$ & $<5$ & $<5$ & 1,150 & 1,900 & 10.8 & 7,260 \\
\hline CC-22 & 1 & CH 5149 & $4 / 24 / 96$ & $<5$ & $<20$ & $<5$ & $<5$ & 41.5 & 15.7 & $<5$ & 10.6 \\
\hline $\begin{array}{l}\text { Site well- } \\
\text { identification } \\
\text { number }\end{array}$ & Notes & $\begin{array}{c}\text { U.S. } \\
\text { Geological } \\
\text { Survey well- } \\
\text { identification } \\
\text { number }\end{array}$ & Date & Toluene & $\begin{array}{l}\text { Vinyl } \\
\text { acetate }\end{array}$ & $\begin{array}{c}\text { Vinyl } \\
\text { chloride }\end{array}$ & $\begin{array}{l}\mathrm{m}-\text { and } \mathrm{p}- \\
\text { Xylenes }\end{array}$ & o-Xylenes & & & \\
\hline CC-15 & 1 & $\mathrm{CH} 5142$ & $4 / 15 / 96$ & $<5$ & $<10$ & $<10$ & $<5$ & $<5$ & & & \\
\hline CC-16 & 1 & CH 5143 & $4 / 17 / 96$ & $<5$ & $<10$ & $<10$ & $<5$ & $<5$ & & & \\
\hline CC-16 & 2 & & $5 / 22 / 96$ & $<5$ & $<10$ & $<10$ & $<5$ & $<5$ & & & \\
\hline CC-17 & 1 & CH 5144 & $4 / 17 / 96$ & $<5$ & $<10$ & $<10$ & $<5$ & $<5$ & & & \\
\hline $\mathrm{CC}-17$ & 2 & & $5 / 17 / 96$ & $<5$ & $<10$ & $<10$ & $<5$ & $<5$ & & & \\
\hline CC-18 & 1 & CH 5145 & $4 / 17 / 96$ & $<5$ & $<10$ & $<10$ & $<5$ & $<5$ & & & \\
\hline CC-19 & 3 & CH 5146 & & & & & & & & & \\
\hline \multicolumn{2}{|c|}{ Upper zone } & & $5 / 02 / 96$ & $<5$ & $<10$ & $<10$ & $<5$ & $<5$ & & & \\
\hline \multicolumn{2}{|c|}{ Lower zone } & & $5 / 02 / 96$ & $<5$ & $<10$ & $<10$ & $<5$ & $<5$ & & & \\
\hline CC-19 & 2 & & $5 / 22 / 96$ & $<5$ & $<10$ & $<10$ & $<5$ & $<5$ & & & \\
\hline CC-20 & 1 & $\mathrm{CH} 5147$ & 4/22/96 & $<5$ & $<10$ & $<10$ & $<5$ & $<5$ & & & \\
\hline CC-21 & 1 & CH 5148 & 4/22/96 & $<5$ & $<10$ & $<10$ & $<5$ & $<5$ & & & \\
\hline CC-21 & 2 & & $5 / 24 / 96$ & $<5$ & $<10$ & $<10$ & $<5$ & $<5$ & & & \\
\hline CC-22 & 1 & CH 5149 & 4/24/96 & $<5$ & $<10$ & $<10$ & $<5$ & $<5$ & & & \\
\hline
\end{tabular}


Table 2. Results of chemical analyses for volatile organic compounds in water samples from on-site wells, Malvern TCE Site, Chester County, Pennsylvania. Data provided by L.R. Dietz (U.S. Environmental Protection Agency, written commun., 1996)

[Concentrations in micrograms per liter; --, no data; <, less than; $\mathrm{B}$, compound found in blanks; $\mathrm{C}$, concentration reported from diluted sample; E, estimated concentration; J, estimated concentration below reporting limit; UJ, nondetected estimated]

\begin{tabular}{|c|c|c|c|c|c|c|c|c|c|c|}
\hline $\begin{array}{l}\text { Site well- } \\
\text { identification } \\
\text { number }\end{array}$ & $\begin{array}{c}\text { U.S. } \\
\text { Geological } \\
\text { Survey well- } \\
\text { identification } \\
\text { number }\end{array}$ & Date & $\begin{array}{l}\text { Time of } \\
\text { sample }\end{array}$ & Acetone & Benzene & $\begin{array}{l}\text { Bromodi- } \\
\text { chloro- } \\
\text { methane }\end{array}$ & $\begin{array}{c}\text { Carbon } \\
\text { disulfide }\end{array}$ & $\begin{array}{l}\text { Carbon } \\
\text { tetrachloride }\end{array}$ & $\begin{array}{l}\text { Chloro- } \\
\text { ethane }\end{array}$ & Chloroform \\
\hline CC-2 & $\mathrm{CH} 5119$ & $05 / 03 / 96$ & -- & $<1$ & $<1$ & $<1$ & $<1$ & $<1$ & $<1$ & $<1$ \\
\hline CC-3 & CH 2672 & 05/07/96 & -- & $<1$ & 1.6 & $<1$ & $.1 \mathrm{~J}$ & $<1$ & $<1$ & $85 \mathrm{~J}$ \\
\hline CC-5 & CH 5121 & $05 / 02 / 96$ & -- & $<1$ & $<1$ & $<1$ & $<1$ & $<1$ & $<1$ & $5 \mathrm{~B}$ \\
\hline CC-6 & $\mathrm{CH} 4405$ & 05/07/96 & -- & $<1$ & $<1$ & $<1$ & $<1$ & 7.6 & $<1$ & $4,160 \mathrm{C}$ \\
\hline CC-7 & $\mathrm{CH} 4398$ & 05/07/96 & -- & $<1$ & $<1$ & $<1$ & $<1$ & $<1$ & 1.3 & $46 \mathrm{~J}$ \\
\hline CC-9 & $\mathrm{CH} 4395$ & 05/03/96 & -- & $<1$ & $<1$ & $<1$ & $<1$ & $<1$ & $<1$ & $<1$ \\
\hline CC-10 & CH 5122 & 05/02/96 & -- & 14.3 & $.5 \mathrm{~J}$ & $<1$ & $<1$ & $<1$ & $<1$ & $<1$ \\
\hline $\mathrm{CC}-11$ & $\mathrm{CH} 5123$ & 05/03/96 & -- & $<1$ & $<1$ & $<1$ & $<1$ & $<1$ & $<1$ & $<1$ \\
\hline CC-13 & $\mathrm{CH} 4404$ & 05/07/96 & -- & $<1$ & $<1$ & $<1$ & $<1$ & $<1$ & $<1$ & $28 \mathrm{~B}$ \\
\hline CC-14 & CH 5124 & $05 / 02 / 96$ & -- & $<1$ & $<1$ & $<1$ & $<1$ & $<1$ & $<1$ & $<1$ \\
\hline CC-15 & CH 5142 & $05 / 02 / 96$ & -- & $<1$ & $.8 \mathrm{~J}$ & $<1$ & $<1$ & $<1$ & $<1$ & $1 \mathrm{~B}$ \\
\hline CC-16 & $\mathrm{CH} 5143$ & $05 / 02 / 96$ & -- & $<1$ & $<1$ & $<1$ & $<1$ & $<1$ & $<1$ & $2 \mathrm{~B}$ \\
\hline CC-16 & & $05 / 14 / 96$ & 0930 & $<10$ & $<10$ & $<10$ & $<10$ & $<10$ & $<10$ & $<10$ \\
\hline CC-16 & & $05 / 14 / 96$ & 2030 & $<17$ & $<17$ & $<17$ & $<17$ & $<17$ & $<17$ & $<17$ \\
\hline CC-16 & & $05 / 15 / 96$ & 0740 & $<17$ & $<17$ & $<17$ & $<17$ & $<17$ & $<17$ & $<17$ \\
\hline CC-17 & CH 5144 & $05 / 02 / 96$ & -- & $<1$ & $<1$ & $<1$ & $<1$ & $<1$ & $<1$ & $2 B$ \\
\hline $\mathrm{CC}-17$ & & 05/16/96 & 1030 & $<10$ & $<10$ & $<10$ & $<10$ & $<10$ & $<10$ & $<10$ \\
\hline $\mathrm{CC}-17$ & & 05/16/96 & 2100 & $<10$ & $<10$ & $<10$ & $<10$ & $<10$ & $<10$ & $<10$ \\
\hline CC-17 & & $05 / 17 / 96$ & 0830 & $<14$ & $<14$ & $<14$ & $<14$ & $<14$ & $<14$ & $<14$ \\
\hline CC-18 & CH 5145 & $05 / 02 / 96$ & -- & $<1$ & $<1$ & $<1$ & $<1$ & $<1$ & $<1$ & $.4 \mathrm{~B}$ \\
\hline CC-19 & CH 5146 & 05/10/96 & -- & $<1$ & $<1$ & $<1$ & $<1$ & 9.3 & $<1$ & $<1$ \\
\hline CC-19 & & 05/21/96 & 0845 & $<10$ & $<10$ & $<10$ & $<10$ & $<10$ & $<10$ & $<10$ \\
\hline CC-19 & & $05 / 21 / 96$ & 2000 & $<46$ & $<46$ & $<46$ & $<46$ & $<46$ & $<46$ & $18 \mathrm{~J}$ \\
\hline CC-19 & & $05 / 22 / 96$ & 0700 & $<53$ & $<53$ & $<53$ & $<53$ & $<53$ & $<53$ & $24 \mathrm{~J}$ \\
\hline CC-20 & $\mathrm{CH} 5147$ & 05/07/96 & -- & $<1$ & $<1$ & $<1$ & $.2 \mathrm{~J}$ & $<1$ & $<1$ & $.2 \mathrm{~B}$ \\
\hline CC-21 & CH 5148 & 05/07/96 & -- & $<1$ & $<1$ & $<1$ & $<1$ & $<1$ & $<1$ & $3 \mathrm{~B}$ \\
\hline CC-21 & & $05 / 23 / 96$ & 0900 & $<220$ & $<220$ & $<220$ & $<220$ & $<220$ & $<220$ & $<220$ \\
\hline CC-21 & & $05 / 23 / 96$ & 2000 & $<220$ & $<220$ & $<220$ & $<220$ & $<220$ & $<220$ & $<220$ \\
\hline CC-21 & & $05 / 24 / 96$ & 0700 & $<500$ & $<500$ & $<500$ & $<500$ & $<500$ & $<500$ & $<500$ \\
\hline CC-22 & CH 5149 & 05/07/96 & -- & $<1$ & $<1$ & $<1$ & $<1$ & $<1$ & $<1$ & $.3 \mathrm{~B}$ \\
\hline
\end{tabular}


Table 2. Results of chemical analyses for volatile organic compounds in water samples from on-site wells, Malvern TCE Site, Chester County, Pennsylvania. Data provided by L.R. Dietz (U.S. Environmental Protection Agency, written commun., 1996)—Continued

[Concentrations in micrograms per liter; --, no data; <, less than; $\mathrm{B}$, compound found in blanks; $\mathrm{C}$, concentration reported from diluted sample; E, estimated concentration; J, estimated concentration below reporting limit; UJ, nondetected estimated]

\begin{tabular}{|c|c|c|c|c|c|c|c|c|c|c|c|}
\hline $\begin{array}{l}\text { Site well- } \\
\text { identification } \\
\text { number }\end{array}$ & $\begin{array}{l}\text { U.S. } \\
\text { Geological } \\
\text { Survey well- } \\
\text { identification } \\
\text { number }\end{array}$ & Date & $\begin{array}{l}\text { Time of } \\
\text { sample }\end{array}$ & $\begin{array}{l}\text { 1,1-Dichloro- } \\
\text { ethane }\end{array}$ & $\begin{array}{l}\text { 1,2-Dichloro- } \\
\text { ethane }\end{array}$ & $\begin{array}{l}\text { trans-1,2- } \\
\text { Dichloro- } \\
\text { ethylene }\end{array}$ & $\begin{array}{c}\text { Ethyl } \\
\text { benzene }\end{array}$ & $\begin{array}{l}\text { 1,1-Dichloro- } \\
\text { ethene }\end{array}$ & $\begin{array}{l}\text { cis-1,2- } \\
\text { Dichloro- } \\
\text { ethylene }\end{array}$ & $\begin{array}{l}\text { Methylene } \\
\text { chloride }\end{array}$ & $\begin{array}{c}1,1,1,2 \text {-Tetra- } \\
\text { chloro- } \\
\text { ethane }\end{array}$ \\
\hline CC-2 & $\mathrm{CH} 5119$ & $05 / 03 / 96$ & -- & 8.0 & $<1$ & $0.2 \mathrm{~J}$ & $<1$ & $<1$ & 13.2 & $0.2 \mathrm{~B}$ & $<1$ \\
\hline CC-3 & CH 2672 & 05/07/96 & -- & 18.8 & 2.6 & 2.6 & $<1$ & $963 \mathrm{C}$ & 290 J,C & $.2 \mathrm{~B}$ & $<1$ \\
\hline CC-5 & CH 5121 & 05/02/96 & -- & 10.3 & $50.5 \mathrm{C}$ & 7.7 & $<1$ & $42.2 \mathrm{C}$ & $2,190 \mathrm{C}$ & $<1$ & $<1$ \\
\hline CC-6 & $\mathrm{CH} 4405$ & 05/07/96 & -- & $57 \mathrm{~J}$ & $1,130 \mathrm{C}$ & 6.6 & $<1$ & $4,230 \mathrm{C}$ & $1,280 \mathrm{C}$ & 5.2 & 6.4 \\
\hline CC-7 & CH 4398 & 05/07/96 & -- & $917 \mathrm{C}$ & $4,960 \mathrm{C}$ & $50 \mathrm{~J}$ & $<1$ & $805 \mathrm{C}$ & $16,500 \mathrm{C}$ & 31.9 & $<1$ \\
\hline CC-9 & CH 4395 & 05/03/96 & -- & $<1$ & 2.2 & $<1$ & $<1$ & 1.8 & 6.0 & $<1$ & $<1$ \\
\hline CC-10 & CH 5122 & 05/02/96 & -- & $<1$ & $.8 \mathrm{~J}$ & $<1$ & $<1$ & $<1$ & 9.0 & $<1$ & $<1$ \\
\hline CC-11 & CH 5123 & 05/03/96 & -- & $<1$ & $<1$ & $<1$ & $<1$ & $<1$ & $<1$ & UJ & $<1$ \\
\hline CC-13 & $\mathrm{CH} 4404$ & 05/07/96 & -- & $63 \mathrm{~J}$ & $184 \mathrm{C}$ & 1.6 & $<1$ & $131 \mathrm{C}$ & $434 \mathrm{C}$ & 2.5 & $<1$ \\
\hline CC-14 & CH 5124 & 05/02/96 & -- & $.4 \mathrm{~J}$ & $.5 \mathrm{~J}$ & $<1$ & $<1$ & $.7 \mathrm{~J}$ & 9.6 & $.3 \mathrm{~B}$ & $<1$ \\
\hline CC-15 & CH 5142 & 05/02/96 & -- & 1.4 & 2.5 & $<1$ & $<1$ & 9.2 & 28.4 & $<1$ & $<1$ \\
\hline CC-16 & CH 5143 & 05/02/96 & -- & 3 & 9.3 & $.6 \mathrm{~J}$ & $.3 \mathrm{~J}$ & 19.9 & $121 \mathrm{C}$ & $<1$ & $<1$ \\
\hline CC-16 & & $05 / 14 / 96$ & 0930 & $3 \mathrm{~J}$ & $8 \mathrm{~J}$ & ${ }^{1} 200$ & $<10$ & 19 & -- & $<10$ & $<10$ \\
\hline CC-16 & & $05 / 14 / 96$ & 2030 & $4 \mathrm{~J}$ & $9 \mathrm{~J}$ & ${ }^{1} 290$ & $<17$ & 19 & -- & $2 \mathrm{~J}$ & $<17$ \\
\hline CC-16 & & 05/15/96 & 0740 & $4 \mathrm{~J}$ & $9 \mathrm{~J}$ & ${ }^{1} 320$ & $<17$ & 20 & -- & $3 \mathrm{~J}$ & $<17$ \\
\hline CC-17 & CH 5144 & 05/02/96 & -- & 1.2 & 3.2 & 1.1 & $<1$ & 5.3 & $101 \mathrm{C}$ & $.2 \mathrm{~B}$ & $<1$ \\
\hline CC-17 & & 05/16/96 & 1030 & $<10$ & $<10$ & ${ }^{1} 110$ & $<10$ & $2 \mathrm{~J}$ & -- & $<10$ & $<10$ \\
\hline CC-17 & & 05/16/96 & 2100 & $<10$ & $<10$ & ${ }^{1} 170$ & $<10$ & $5 \mathrm{~J}$ & -- & $<10$ & $<10$ \\
\hline CC-17 & & 05/17/96 & 0830 & $<14$ & $<14$ & ${ }^{1} 220$ & $<14$ & $4 \mathrm{~J}$ & -- & $<10$ & $<10$ \\
\hline CC-18 & CH 5145 & 05/02/96 & -- & $.3 \mathrm{~J}$ & 1.2 & $<1$ & $<1$ & 1.1 & 27.9 & $<1$ & $<1$ \\
\hline CC-19 & CH 5146 & 05/10/96 & -- & $<1$ & $<1$ & $<1$ & $<1$ & 9.2 & 3.1 & $<1$ & $<1$ \\
\hline CC-19 & & 05/21/96 & 0845 & $<10$ & $<10$ & ${ }^{1} 5 \mathrm{~J}$ & $<10$ & $7 \mathrm{~J}$ & -- & $2 \mathrm{~J}$ & $<10$ \\
\hline CC-19 & & 05/21/96 & 2000 & $<46$ & $18 \mathrm{~J}$ & ${ }^{1} 64$ & $<46$ & $42 \mathrm{~J}$ & -- & $<46$ & $<46$ \\
\hline CC-19 & & 05/22/96 & 0700 & $<53$ & $25 \mathrm{~J}$ & ${ }^{1} 86$ & $<53$ & $48 \mathrm{~J}$ & -- & $<53$ & $<53$ \\
\hline CC-20 & CH 5147 & 05/07/96 & -- & $<1$ & 1.5 & $<1$ & $<1$ & $.7 \mathrm{~J}$ & 2.6 & $<1$ & $<1$ \\
\hline CC-21 & CH 5148 & 05/07/96 & -- & 1.6 & 1.6 & $<1$ & $<1$ & 35.0 & 15.2 & $<1$ & $<1$ \\
\hline CC-21 & & 05/23/96 & 0900 & $35 \mathrm{~J}$ & $140 \mathrm{~J}$ & ${ }^{1} 650$ & $<220$ & 320 & -- & $44 \mathrm{~J}, \mathrm{~B}$ & $<220$ \\
\hline CC-21 & & 05/23/96 & 2000 & $34 \mathrm{~J}$ & $150 \mathrm{~J}$ & ${ }^{1} 620$ & $<220$ & 380 & -- & $51 \mathrm{~J}, \mathrm{~B}$ & $<220$ \\
\hline CC-21 & & 05/24/96 & 0700 & $<500$ & $170 \mathrm{~J}$ & ${ }^{1} 580$ & $<500$ & $370 \mathrm{~J}$ & -- & $110 \mathrm{~J}, \mathrm{~B}$ & $<500$ \\
\hline CC-22 & CH 5149 & 05/07/96 & -- & $<1$ & $.2 \mathrm{~J}$ & $<1$ & $<1$ & 1.9 & $<1$ & $<1$ & $<1$ \\
\hline
\end{tabular}


Table 2. Results of chemical analyses for volatile organic compounds in water samples from on-site wells, Malvern TCE Site, Chester County, Pennsylvania. Data provided by L.R. Dietz (U.S. Environmental Protection Agency, written commun., 1996)—Continued

[Concentrations in micrograms per liter; --, no data; <, less than; $\mathrm{B}$, compound found in blanks; $\mathrm{C}$, concentration reported from diluted sample; E, estimated concentration; J, estimated concentration below reporting limit; UJ, nondetected estimated]

\begin{tabular}{|c|c|c|c|c|c|c|c|c|c|c|c|c|}
\hline $\begin{array}{l}\text { Site well- } \\
\text { identification } \\
\text { number }\end{array}$ & $\begin{array}{c}\text { U.S. } \\
\text { Geological } \\
\text { Survey well- } \\
\text { identification } \\
\text { number }\end{array}$ & Date & $\begin{array}{l}\text { Time of } \\
\text { sample }\end{array}$ & $\begin{array}{c}\text { 1,1,2,2- } \\
\text { Tetra- } \\
\text { chloro- } \\
\text { ethane }\end{array}$ & $\begin{array}{l}\text { Tetrachloro- } \\
\text { ethylene }\end{array}$ & $\begin{array}{c}1,1,1- \\
\text { Trichloro- } \\
\text { ethane }\end{array}$ & $\begin{array}{c}1,1,2- \\
\text { Trichloro- } \\
\text { ethane }\end{array}$ & $\begin{array}{l}\text { Trichloro- } \\
\text { ethylene }\end{array}$ & Toluene & $\begin{array}{c}\text { Vinyl } \\
\text { chloride }\end{array}$ & $\begin{array}{l}\mathrm{m} \text { - and } \mathrm{p}- \\
\text { Xylenes }\end{array}$ & o-Xylenes \\
\hline CC-2 & $\mathrm{CH} 5119$ & $05 / 03 / 96$ & -- & $<1$ & 4.9 & 6.5 & $0.2 \mathrm{~J}$ & 33.0 & $0.2 \mathrm{~J}$ & $<1$ & $<1$ & $<1$ \\
\hline CC-3 & CH 2672 & 05/07/96 & -- & $<1$ & $1,830 \mathrm{C}$ & $2,650 \mathrm{C}$ & 1.8 & $12,700 \mathrm{C}$ & $.7 \mathrm{~J}$ & $<1$ & $<1$ & $<1$ \\
\hline CC-5 & CH 5121 & 05/02/96 & -- & $<1$ & $111 \mathrm{C}$ & $108 \mathrm{C}$ & $.6 \mathrm{~J}$ & $768 \mathrm{C}$ & 3.4 & 1.1 & $<1$ & $<1$ \\
\hline CC-9 & $\mathrm{CH} 4395$ & 05/03/96 & -- & $<1$ & 7.6 & 3.7 & $<1$ & 8.1 & $<1$ & $<1$ & $<1$ & $<1$ \\
\hline CC-10 & CH 5122 & 05/02/96 & -- & $<1$ & 2.3 & $.4 \mathrm{~J}$ & $<1$ & 2.1 & 1.6 & $<1$ & $<1$ & $<1$ \\
\hline CC-11 & CH 5123 & 05/03/96 & -- & $<1$ & $<1$ & $<1$ & $<1$ & $<1$ & 1.4 & $<1$ & $<1$ & $<1$ \\
\hline CC-13 & $\mathrm{CH} 4404$ & 05/07/96 & -- & $<1$ & $569 \mathrm{C}$ & $509 \mathrm{C}$ & 1.6 & $1,510 \mathrm{C}$ & 1.6 & $<1$ & $<1$ & $<1$ \\
\hline CC-14 & CH 5124 & 05/02/96 & -- & $<1$ & $.9 \mathrm{~J}$ & 2.4 & $<1$ & 16.7 & $.5 \mathrm{~J}$ & $<1$ & $<1$ & $<1$ \\
\hline CC-16 & & 05/15/96 & 0740 & $<17$ & 95 & 99 & $<17$ & 170 & $<17$ & $<17$ & ${ }^{2}<17$ & -- \\
\hline CC-17 & CH 5144 & 05/02/96 & -- & $<1$ & 36.4 & 23.5 & 1.1 & $67.5 \mathrm{C}$ & $<1$ & $<1$ & $<1$ & $<1$ \\
\hline CC-17 & & 05/16/96 & 1030 & $<10$ & 22 & 14 & $<10$ & 58 & $<10$ & $<10$ & ${ }^{2}<10$ & -- \\
\hline CC-17 & & $05 / 16 / 96$ & 2100 & $<10$ & 26 & 21 & $1 \mathrm{~J}$ & 81 & $<10$ & $<10$ & ${ }^{2}<10$ & -- \\
\hline CC-17 & & $05 / 17 / 96$ & 0830 & $<14$ & 30 & 25 & $2 \mathrm{~J}$ & 97 & $<10$ & $<10$ & ${ }^{2}<10$ & -- \\
\hline CC-18 & CH 5145 & 05/02/96 & -- & $<1$ & 2.8 & 7.0 & $.6 \mathrm{~J}$ & 13.1 & 1.1 & $<1$ & $<1$ & $<1$ \\
\hline CC-19 & CH 5146 & 05/10/96 & -- & $<1$ & $41.1 \mathrm{C}$ & 29.2 & $<1$ & $74.5 \mathrm{C}$ & $<1$ & $<1$ & $<1$ & $<1$ \\
\hline CC-19 & & 05/21/96 & 0845 & $<10$ & 58 & 33 & $<10$ & 120 & $<10$ & $<10$ & ${ }^{2}<10$ & -- \\
\hline CC-19 & & 05/21/96 & 2000 & $<46$ & 180 & 210 & $<46$ & 830 & $<46$ & $<46$ & $<46$ & -- \\
\hline CC-19 & & 05/22/96 & 0700 & $<53$ & 230 & 270 & $<53$ & $1,100 \mathrm{E}$ & $<53$ & $<53$ & $<53$ & -- \\
\hline CC-20 & CH 5147 & 05/07/96 & -- & $<1$ & 3.9 & 2.4 & $<1$ & 8.5 & $.3 \mathrm{~J}$ & $<1$ & $<1$ & $<1$ \\
\hline
\end{tabular}

\footnotetext{
1 Total of trans-1,2-dichloroethylene and cis-1,2-dichloroethylene.
}

2 Total of $\mathrm{m}-, \mathrm{p}-$, and o-xylenes. 
Table 3. Results of chemical analyses for volatile organic compounds detected in water samples from off-site wells, Malvern TCE Site, Chester County, Pennsylvania. Data provided by L.R. Dietz (U.S. Environmental Protection Agency, written commun., 1996)

[Concentrations in micrograms per liter; B, compound found in blanks; C, concentration reported from diluted sample;

$\mathrm{J}$, estimated concentration; ND, compound not detected, minimum detection limit not known]

\begin{tabular}{|c|c|c|c|c|c|c|c|c|c|}
\hline $\begin{array}{l}\text { Off-site well- } \\
\text { identification } \\
\text { number }\end{array}$ & Date & 2-Butanone & $\begin{array}{l}\text { Carbon } \\
\text { disulfide }\end{array}$ & Chloroform & $\begin{array}{l}\text { 1,1-Dichloro- } \\
\text { ethane }\end{array}$ & $\begin{array}{l}\text { 1,1-Dichloro- } \\
\text { ethene }\end{array}$ & $\begin{array}{l}\text { cis-1,2- } \\
\text { Dichloro- } \\
\text { ethylene }\end{array}$ & $\begin{array}{c}\text { trans-1,2- } \\
\text { Dichloroethylene }\end{array}$ & $\begin{array}{c}\text { Methylene } \\
\text { chloride }\end{array}$ \\
\hline DW-1 & $06 / 08 / 95$ & ND & ND & ND & ND & ND & ND & ND & ND \\
\hline DW-2 & 06/08/95 & ND & ND & 1.2 & ND & ND & ND & ND & ND \\
\hline DW-3 & 06/07/95 & ND & ND & ND & ND & ND & ND & ND & $1 \mathrm{~B}$ \\
\hline DW-3 & $12 / 12 / 95$ & ND & ND & ND & ND & ND & ND & ND & $.3 \mathrm{~B}$ \\
\hline DW-4 & 06/07/95 & ND & ND & ND & ND & ND & ND & ND & $.7 \mathrm{~B}$ \\
\hline DW-4 & $12 / 12 / 95$ & ND & ND & ND & ND & ND & ND & ND & ND \\
\hline DW-5 & 06/08/95 & ND & ND & ND & ND & ND & ND & ND & ND \\
\hline DW-6 & 08/28/95 & ND & ND & $.1 \mathrm{~B}$ & ND & ND & 14.6 & $.6 \mathrm{~J}$ & ND \\
\hline DW-7 & 06/07/95 & ND & ND & 1 & ND & ND & ND & ND & ND \\
\hline DW-7 & $12 / 11 / 95$ & ND & ND & ND & $.1 \mathrm{~J}$ & ND & ND & ND & $.4 \mathrm{~B}$ \\
\hline DW-12 & 06/12/95 & ND & ND & ND & ND & ND & ND & ND & ND \\
\hline DW-15 & 09/05/95 & ND & ND & $.04 \mathrm{~J}$ & ND & $.5 \mathrm{~J}$ & ND & ND & ND \\
\hline DW-16 & 08/29/95 & ND & ND & $.06 \mathrm{~J}$ & ND & 1.4 & ND & ND & ND \\
\hline DW-23 & 08/29/95 & ND & ND & $.09 \mathrm{~J}$ & ND & $.1 \mathrm{~J}$ & 1.3 & ND & ND \\
\hline DW-30 & 06/13/95 & ND & ND & ND & ND & ND & ND & ND & ND \\
\hline DW-31 & $06 / 12 / 95$ & 21 & ND & ND & ND & ND & ND & ND & ND \\
\hline DW-32 & 06/13/95 & ND & ND & ND & ND & ND & ND & ND & ND \\
\hline DW-33 & 08/28/95 & ND & ND & $.2 \mathrm{~B}$ & ND & ND & ND & ND & ND \\
\hline DW-36 & 08/29/95 & ND & ND & $.8 \mathrm{~J}$ & $.3 \mathrm{~J}$ & 7.2 & $20.3 \mathrm{C}$ & $.4 \mathrm{~J}$ & ND \\
\hline DW-42 & 06/07/95 & ND & ND & ND & ND & ND & ND & ND & ND \\
\hline DW-42 & $12 / 11 / 95$ & ND & ND & ND & ND & ND & ND & ND & $.2 \mathrm{~B}$ \\
\hline DW-43 & 06/07/95 & ND & ND & ND & ND & ND & ND & ND & $.8 \mathrm{~B}$ \\
\hline DW-43 & $12 / 12 / 95$ & ND & ND & ND & ND & ND & ND & ND & $.3 \mathrm{~B}$ \\
\hline DW-44 & 08/29/95 & ND & ND & $.5 \mathrm{~J}$ & $.05 \mathrm{~J}$ & ND & ND & ND & ND \\
\hline DW-45 & 06/09/95 & ND & ND & ND & ND & ND & ND & ND & ND \\
\hline DW-46 & $06 / 12 / 95$ & ND & ND & ND & ND & 1.1 & ND & ND & ND \\
\hline DW-47 & $06 / 12 / 95$ & ND & ND & ND & ND & ND & ND & ND & ND \\
\hline DW-48 & $06 / 12 / 95$ & ND & 8.4 & ND & ND & ND & ND & ND & ND \\
\hline DW-49 & 06/09/95 & ND & ND & ND & ND & ND & ND & ND & $.7 \mathrm{~B}$ \\
\hline DW-50 & 06/15/95 & $2.2 \mathrm{~J}$ & ND & ND & ND & ND & ND & ND & ND \\
\hline DW-50 & 08/28/95 & ND & ND & $.3 \mathrm{~J}$ & ND & ND & ND & ND & ND \\
\hline DW-51 & 06/08/95 & ND & ND & ND & ND & ND & ND & ND & ND \\
\hline DW-52 & 08/29/95 & ND & ND & ND & ND & ND & ND & ND & ND \\
\hline DW-53 & 06/07/95 & ND & ND & ND & ND & ND & ND & ND & $.7 \mathrm{~B}$ \\
\hline DW-53 & $12 / 11 / 95$ & ND & ND & ND & ND & ND & ND & ND & $.3 \mathrm{~B}$ \\
\hline DW-54 & 06/07/95 & ND & ND & ND & ND & ND & ND & ND & ND \\
\hline DW-54 & $12 / 12 / 95$ & ND & ND & ND & ND & ND & ND & ND & $.2 \mathrm{~B}$ \\
\hline DW-55 & 09/05/95 & ND & ND & ND & ND & ND & 2.8 & ND & ND \\
\hline DW-56 & 08/28/95 & ND & ND & $.3 \mathrm{~J}$ & ND & ND & $.7 \mathrm{~J}$ & ND & ND \\
\hline DW-57 & 08/29/95 & ND & ND & $.08 \mathrm{~J}$ & ND & ND & 11 & $.2 \mathrm{~J}$ & ND \\
\hline DW-60 & 06/08/95 & ND & ND & ND & ND & ND & ND & ND & $.7 \mathrm{~B}$ \\
\hline DW-60 & $12 / 15 / 95$ & ND & ND & ND & ND & ND & ND & ND & ND \\
\hline DW-61 & $06 / 14 / 95$ & ND & ND & ND & ND & ND & ND & ND & ND \\
\hline DW-62 & $06 / 14 / 95$ & ND & ND & ND & ND & ND & ND & ND & ND \\
\hline DW-63 & 06/19/95 & ND & ND & ND & ND & ND & ND & ND & ND \\
\hline DW-64 & 06/09/95 & ND & ND & ND & ND & ND & ND & ND & $.5 \mathrm{~B}$ \\
\hline DW-65 & 08/29/95 & ND & ND & $.09 \mathrm{~J}$ & ND & ND & ND & ND & ND \\
\hline DW-66 & 06/08/95 & ND & ND & ND & ND & ND & ND & ND & ND \\
\hline DW-66 & $12 / 11 / 95$ & ND & ND & ND & ND & ND & ND & ND & $.3 \mathrm{~B}$ \\
\hline DW-67 & 08/28/95 & ND & ND & ND & ND & $.09 \mathrm{~J}$ & $.5 \mathrm{~J}$ & ND & ND \\
\hline DW-69 & $06 / 12 / 95$ & ND & ND & ND & ND & ND & ND & ND & ND \\
\hline DW-70 & 06/13/95 & ND & ND & ND & ND & ND & ND & ND & ND \\
\hline DW-71 & 06/09/95 & ND & ND & ND & ND & ND & ND & ND & ND \\
\hline DW-100 & 06/12/95 & 10 & $2.2 \mathrm{~B}$ & ND & ND & ND & ND & ND & ND \\
\hline
\end{tabular}


Table 3. Results of chemical analyses for volatile organic compounds detected in water samples from off-site wells, Malvern TCE Site, Chester County, Pennsylvania. Data provided by L.R. Dietz (U.S. Environmental Protection Agency, written commun., 1996)—Continued

[Concentrations in micrograms per liter; B, compound found in blanks; C, concentration reported from diluted sample;

$\mathrm{J}$, estimated concentration; ND, compound not detected, minimum detection limit not known]

\begin{tabular}{|c|c|c|c|c|c|c|c|}
\hline $\begin{array}{c}\text { Off-site well- } \\
\text { identification } \\
\text { number }\end{array}$ & $\begin{array}{c}\text { Date } \\
\text { sampled }\end{array}$ & $\begin{array}{l}\text { Tetrachloro- } \\
\text { ethylene }\end{array}$ & $\begin{array}{c}1,1,1- \\
\text { Trichloro- } \\
\text { ethane }\end{array}$ & $\begin{array}{c}1,1,2- \\
\text { Trichloro- } \\
\text { ethane }\end{array}$ & $\begin{array}{l}\text { Trichloro- } \\
\text { ethylene }\end{array}$ & $\begin{array}{l}\text { Trichloro- } \\
\text { fluoro- } \\
\text { methane }\end{array}$ & Toluene \\
\hline DW-1 & $06 / 08 / 95$ & ND & ND & ND & ND & ND & ND \\
\hline DW-2 & 06/08/95 & ND & ND & ND & ND & ND & ND \\
\hline DW-3 & 06/07/95 & ND & ND & ND & ND & ND & ND \\
\hline DW-3 & 12/12/95 & ND & ND & ND & ND & ND & ND \\
\hline DW-4 & 06/07/95 & ND & ND & ND & ND & ND & ND \\
\hline DW-4 & 12/12/95 & ND & ND & ND & ND & ND & ND \\
\hline DW-5 & 06/08/95 & ND & ND & ND & ND & ND & ND \\
\hline DW-6 & 08/28/95 & 5.2 & ND & $0.7 \mathrm{~J}$ & $29.1 \mathrm{C}$ & $0.6 \mathrm{~J}$ & $0.03 \mathrm{~J}$ \\
\hline DW-7 & 06/07/95 & ND & ND & ND & ND & ND & ND \\
\hline DW-7 & 12/11/95 & $.4 \mathrm{~J}$ & ND & ND & $.6 \mathrm{~J}$ & ND & ND \\
\hline DW-12 & $06 / 12 / 95$ & ND & $0.7 \mathrm{~J}$ & ND & ND & ND & ND \\
\hline DW-15 & 09/05/95 & $.08 \mathrm{~J}$ & 1.5 & ND & $.2 \mathrm{~J}$ & ND & ND \\
\hline DW-16 & 08/29/95 & ND & 5.8 & ND & ND & $.06 \mathrm{~J}$ & ND \\
\hline DW-23 & 08/29/95 & $.4 \mathrm{~J}$ & $.8 \mathrm{~J}$ & ND & $.8 \mathrm{~J}$ & ND & ND \\
\hline DW-30 & $06 / 13 / 95$ & ND & ND & ND & ND & ND & ND \\
\hline DW-31 & 06/12/95 & ND & ND & ND & ND & ND & ND \\
\hline DW-32 & $06 / 13 / 95$ & ND & ND & ND & ND & ND & ND \\
\hline DW-33 & $08 / 28 / 95$ & ND & ND & ND & ND & ND & ND \\
\hline DW-36 & 08/29/95 & 10.7 & $24.2 \mathrm{C}$ & $.4 \mathrm{~J}$ & $56.5 \mathrm{C}$ & $.06 \mathrm{~J}$ & ND \\
\hline DW-42 & 06/07/95 & ND & ND & ND & ND & ND & ND \\
\hline DW-42 & 12/11/95 & $.1 \mathrm{~J}$ & $.2 \mathrm{~J}$ & ND & $.2 \mathrm{~J}$ & ND & ND \\
\hline DW-43 & 06/07/95 & ND & ND & ND & ND & ND & ND \\
\hline DW-43 & 12/12/95 & ND & ND & ND & ND & ND & ND \\
\hline DW-44 & 08/29/95 & $.4 \mathrm{~J}$ & ND & ND & $.1 \mathrm{~J}$ & ND & ND \\
\hline DW-45 & 06/09/95 & ND & $.9 \mathrm{~J}$ & ND & ND & ND & ND \\
\hline DW-46 & $06 / 12 / 95$ & ND & 1.9 & ND & ND & ND & ND \\
\hline DW-47 & $06 / 12 / 95$ & $.8 \mathrm{~J}$ & ND & ND & ND & ND & ND \\
\hline DW-48 & $06 / 12 / 95$ & ND & ND & ND & ND & ND & ND \\
\hline DW-49 & 06/09/95 & ND & ND & ND & ND & ND & ND \\
\hline DW-50 & 06/15/95 & ND & ND & ND & ND & ND & ND \\
\hline DW-50 & $08 / 28 / 95$ & ND & $.1 \mathrm{~J}$ & ND & ND & ND & ND \\
\hline DW-51 & 06/08/95 & ND & ND & ND & ND & ND & ND \\
\hline DW-52 & 08/29/95 & ND & ND & ND & ND & ND & ND \\
\hline DW-53 & 06/07/95 & ND & ND & ND & ND & ND & ND \\
\hline DW-53 & 12/11/95 & ND & ND & ND & ND & ND & ND \\
\hline DW-54 & 06/07/95 & ND & ND & ND & ND & ND & ND \\
\hline DW-54 & 12/12/95 & $.2 \mathrm{~J}$ & ND & ND & ND & ND & ND \\
\hline DW-55 & 09/05/95 & 1.3 & ND & ND & 7.4 & $.2 \mathrm{~J}$ & ND \\
\hline DW-56 & 08/28/95 & $.2 \mathrm{~J}$ & ND & ND & 1.5 & $.06 \mathrm{~J}$ & ND \\
\hline DW-57 & 08/29/95 & 3.4 & ND & $.5 \mathrm{~J}$ & $21 \mathrm{~J}$ & $.7 \mathrm{~J}$ & .04 \\
\hline DW-60 & 06/08/95 & ND & ND & ND & ND & ND & ND \\
\hline DW-60 & 12/15/95 & ND & ND & ND & ND & ND & ND \\
\hline DW-61 & $06 / 14 / 95$ & ND & ND & ND & ND & ND & ND \\
\hline DW-62 & $06 / 14 / 95$ & ND & ND & ND & ND & ND & ND \\
\hline DW-63 & 06/19/95 & ND & ND & ND & ND & ND & ND \\
\hline DW-64 & 06/09/95 & ND & ND & ND & ND & ND & ND \\
\hline DW-65 & 08/29/95 & 15.1 & $.2 \mathrm{~J}$ & ND & 9 & ND & ND \\
\hline DW-66 & 06/08/95 & $.6 \mathrm{~B}$ & $.8 \mathrm{~J}$ & ND & ND & ND & ND \\
\hline DW-66 & 12/11/95 & $.1 \mathrm{~J}$ & ND & ND & $.3 \mathrm{~J}$ & ND & ND \\
\hline DW-67 & $08 / 28 / 95$ & ND & $.4 \mathrm{~J}$ & ND & 14.7 & ND & ND \\
\hline DW-69 & $06 / 12 / 95$ & ND & ND & ND & ND & ND & ND \\
\hline DW-70 & 06/13/95 & ND & ND & ND & ND & ND & ND \\
\hline DW-71 & 06/09/95 & ND & $1 \mathrm{~J}$ & ND & ND & ND & ND \\
\hline DW-100 & $06 / 12 / 95$ & ND & $.9 \mathrm{~J}$ & ND & $.5 \mathrm{~J}$ & ND & ND \\
\hline
\end{tabular}

